Diana Francisca Adamatti

\title{
Inserção de Jogadores Virtuais em Jogos de Papéis para Uso em Sistemas de Apoio à Decisão em Grupo: Um Experimento no Domínio da Gestão de Recursos Naturais
}

Texto apresentado à Escola Politécnica da Universidade de São Paulo para obtenção do Título de Doutor em Engenharia Elétrica. 
Diana Francisca Adamatti

\title{
Inserção de Jogadores Virtuais em Jogos de Papéis para Uso em Sistemas de Apoio à Decisão em Grupo: Um Experimento no Domínio da Gestão de Recursos Naturais
}

\author{
Texto apresentado à Escola Politécnica \\ da Universidade de São Paulo para \\ obtenção do Título de Doutor em \\ Engenharia Elétrica. \\ Área de concentração: \\ Sistemas Digitais \\ Orientador: \\ Prof. Dr. Jaime Simão Sichman
}


Este exemplar foi revisado e alterado em relação a versão original, sob responsabilidade única do autor com a anuência de seu orientador.

São Paulo, 29 de junho de 2007.

Assinatura do autor

Assinatura do orientador

\section{Ficha Catalográfica}

Adamatti, Diana Francisca

Inserção de Jogadores Virtuais em Jogos de Papéis para Uso em Sistemas de Apoio à Decisão em Grupo: Um Experimento no Domínio da Gestão de Recursos Naturais. São Paulo, 2007. 176 p. CD-ROM em Anexo.

Tese (Doutorado) - Escola Politécnica da Universidade de São Paulo. Departamento de Engenharia de Computação e Sistemas Digitais.

1. Simulação Baseada em Multiagentes (MABS). 2. Jogos de Papéis (RPGs). 3. Sistemas de Gestão de Recursos Naturais. 4. Simulação Participativa Multiagentes. I. Universidade de São Paulo. Escola Politécnica. Departamento de Engenharia de Computação e Sistemas Digitais. II. Título. 
Os homens não são, mas sim estão sendo.

Da mesma forma a realidade não é, mas está sendo.

(Paulo Freire)

Aprendi que não posso exigir o amor de ninguém... posso apenas dar boas razões para que gostem de mim e ter paciência para que a vida faça o resto...

(William Shakespeare)

A Vida é o que acontece enquanto estamos ocupados fazendo outros planos.

(John Lennon) 


\section{Agradecimentos}

À minha mãe Maria, minha irmã Luciana e minha madrinha Ires pelo apoio em todos os momentos de minha vida, desde o início e sempre. Com certeza, sem estas maravilhosas mulheres, eu nunca teria chegado ao final de mais esta etapa.

Aos meus grandes amigos do LTI (melhor dizendo "LTIanos"): Valguima, Valdinei, Antonio, Graça, Luciano, Bianchi, Rodrigo, André, Anna, Gustavo, Danilo, Lucas, Inácio, Priscilla e Anarosa. Pessoas maravilhosas, que tive a oportunidade de conhecer! Um obrigado muito especial a minha amiga Regina, que é um exemplo a ser seguido de amizade, trabalho e determinação.

Ao meu orientador, Professor Jaime Simão Sichman, pela oportunidade de desenvolver esse trabalho, sempre ajudando a definir os caminhos e organizar as idéias (nem sempre muito claras pra mim). Vejo que as críticas são sempre muito importantes para que possamos desenvolver melhor tudo na vida. Aprender a aceitá-las é uma tarefa complicada, mas essencial!

Ao Professor Helder Coelho, que me recebeu na Universidade de Lisboa, ajudando muito no desenvolvimento do trabalho e no meu crescimento pessoal. Também gostaria de agradecer às Professoras Ana Paula e Beatriz, pessoas maravilhosas, muito amigas e disponíveis em me auxiliar durante minha estadia em Portugal.

A Dra. Raphaèle Ducrot, coordenadora do projeto Negowat, por ter me dado a oportunidade de trabalhar em um projeto multidisciplinar, tão interessante e inovador. E por ter dedicado diversas horas do seu tempo analisando, ajudando e melhorando este trabalho.

Um especial obrigado ao Professsor Jomi Hübner, pela ajuda (e paciência!) no entendimento e uso do SACI e do Jason. Pessoas com seu conhecimento, simplicidade e boa vontade são raras!

Ao projeto Negowat, ao CNPq (processo número 141851/2004-0) e à CAPES (processo número 0664/05-7) pelo apoio financeiro, indispensável para a realização deste trabalho.

E sobre tudo, a Deus, por ter permitido chegar a este objetivo, que nunca havia pensado conseguir alcançar algum dia, dando sempre esperança, saúde e força. 


\section{Resumo}

Este trabalho propõe a definição de uma arquitetura para incorporar jogadores virtuais em uma classe de Sistemas de Apoio à Decisão em Grupos (SADs-G), baseados na utilização conjunta de Simulação Baseada em Multiagentes (MABS) e Jogos de Papéis (RPGs). Estas duas técnicas, MABS e RPGs, vêm sendo utilizadas de forma integrada há alguns anos devido à capacidade de discussão e aprendizado dos RPG e da capacidade dinâmica de MABS. Os jogadores virtuais definidos devem ter a capacidade de tomada de decisão e de comunicação entre si e com os jogadores reais durante as negociações. Os principais aspectos discutidos neste trabalho são: i) se os jogadores virtuais definidos possuem comportamentos não-triviais perante aos jogadores reais; ii) se continua ocorrendo o processo de negociação entre os jogadores, sejam eles reais ou virtuais; iii) se a realização de um jogo de forma eletrônica (via computador) dificulta a interação entre os jogadores. De forma a discutir estes aspectos, duas instância de SADs-G foram implementadas no contexto da Gestão de Recursos Naturais, pois neste domínio o processo de negociação é extremamente importante e complexo. 


\section{Abstract}

This thesis proposes the definition of an architecture to insert virtual players in a particular subclass of Group Decision Support Systems (GDSS), that uses Multi-Agent-Based Simulation (MABS) and Role-Playing Games (RPGs) techniques in an integrated way. These techniques can bring interesting results, since it is possible to join the dynamic capacity of MABS with the discussion and learning capacity of RPGs. The defined virtual players must make decisions and communicate with each other and with the real players during the negotiation process. In this work, the main aspects discussed are the following: i) can virtual players have no-trivial behavior in the face of real players? ii) is the negotiation process between all players (virtual or real) still happening when virtual players are inserted? iii) do electronic games make more difficult the interaction between players? In order to discuss these aspects, two instances of GDSSs were developed in the natural resources management domain. This domain was chosen because its negotiation process is both very important and complex. 


\section{Lista de Figuras}

Figura 1 - Etapas de um Processo de Simulação (DROGOUL; FERBER, 1992). . . . . . . . . . . . . . . . 12

Figura 2 - Funcionamento da Metodologia GMABS. . . . . . . . . . . 20

Figura 3 - Representação do Conhecimento Declarativo (Chunks) em ACT-R (ANDERSON; MATESSA, 1998). . . . . . . . . 25

Figura 4 - Modelo Conceitual da Arquitetura ACT-R, adaptada de (ANDERSON et al., 1995). . . . . . . . . . . . . . 26

Figura 5 - Estrutura de Divisão de Objetivos na Arquitetura SOAR (LAIRD, 2003).

Figura 6 - Modelo Conceitual da Arquitetura COGNET (ZACHARY; RYDER; HICINBOTHOM, 1998). . . . . . . . . . . . . . . 28

Figura 7 - Estrutura da Arquitetura BDI (NORLING; SONENBERG; RONNQUIST, 2000). . . . . . . . . . . . . . . . . . . . . . . 29

Figura 8 - Teoria de Negociação 2:1 (RAIFFA, 1982). . . . . . . . . . . 34

Figura 9 - Resultados da Simulação para a Estação de Bombeamento de Água e para o Banco (BARRETEAU et al., 2004). . . . . . . . 39

Figura 10 - Etapas da Metodologia Samba-Week (BOISSAU; CASTELLA, 2003). .......................... 40

Figura 11 - Interface de Entrada de Dados do SylvoPast (ETIEnNE, 2003). 42

Figura 12 - Níveis de Administração do JogoMan. A figura a esquerda representa a divisão das cidades (três diferentes cores). A figura a direita representa a divisão pelo uso do solo (diversas cores). . . . . . . . . . . . . . 5 56

Figura 13 - Funcionamento do JogoMan. . . . . . . . . . . . . . . . . . . 61

Figura 14 - Formulário para o Papel de Prefeito no JogoMan. . . . . . . 62

Figura 15 - Elementos da Metodologia GMABS. . . . . . . . . . . . . . 73 
Figura 16 - Elementos da Arquitetura ViP-GMABS. . . . . . . . . . . 74

Figura 17 - Arquitetura Genérica ViP-GMABS. . . . . . . . . . . . . . 74

Figura 18 - Arquitetura Cognitiva dos Jogadores Virtuais. . . . . . . . . 76

Figura 19 - Proprietário Particular 4 - Jogo 2 - Faculdade Integrada de Guarulhos - Utiliza um Perfil Econômico. . . . . . . . . . . 84

Figura 20 - Administrador AGUAPURA - Jogo 2 - Faculdade Integrada de Guarulhos - Utiliza um Perfil Racional. . . . . . . . . . 84

Figura 21 - Prefeito C - Jogo 3 - Faculdade de Saúde Pública da USP Utiliza um Perfil Ambientalista. . . . . . . . . . . 85

Figura 22 - Representante dos SemTeto - Jogo 4 - Universidade de Mogi das Cruzes - Utiliza um Perfil Social. . . . . . . . . 85

Figura 23 - Ferramentas Escolhidas. . . . . . . . . . . . . . . . 89

Figura 24 - Interface gráfica do perfil comportamental com interesse econômico para o papel de Proprietário Particular, codificada em Jason. 94

Figura 25 - Protocolo de Negociação para as Ações Comprar, Alugar e Buscar por Lote Específico. . . . . . . . . . . . . . . 96

Figura 26 - Protocolo de Negociação para as Ações de Colocar Infraestrutura. . . . . . . . . . . . . . . . 96

Figura 27 - Interface Inicial de Acesso ao Jogo. . . . . . . . . . . . . . 100

Figura 28 - Interface do Administrador da AguaPura. . . . . . . . . . . . 102

Figura 29 - Interface do Representante dos SemTeto. . . . . . . . . . . . 102

Figura 30 - Interface dos Prefeitos. . . . . . . . . . . . . . . . 103

Figura 31 - Interface dos Proprietários Particulares. . . . . . . . . . . . . 103

Figura 32 - Interface de Interação Coletiva para Todos os Papéis. . . . . 104 


\section{Lista de Tabelas}

Tabela 1 - Combinação Entre os Tipos de Jogadores e a Forma de Inserção dos Dados no sistema MABS. . . . . . . . . . . 6

Tabela 2 - Divisão dos RPGs a Partir do Tempo e do Local de Realização, Baseado na Área de GroupWare (ELLIS; GIBBS; REIN, 1993). . . . . . . . . . . . . . . 16

Tabela 3 - Síntese dos Métodos de Avaliação Analisados. . . . . . . . . 49

Tabela $4-$ Tipos e Valores dos Usos do Solo. . . . . . . . . . . . . . 58

Tabela 5 - $\quad$ Questionário Pré-Jogo Aplicado nos Jogos-Teste do JogoMan. 68

Tabela 6 - Questionário Pós-Jogo Aplicado nos Jogos-Teste do JogoMan. 68

Tabela 7 - Perfis Comportamentais e Variáveis. . . . . . . . . . . . . . 112

Tabela 8 - Questionário Pré-Jogo para ViP-JogoMan. . . . . . . . . . 113

Tabela 9 - Questionário Pós-Jogo para o ViP-JogoMan. . . . . . . . . 114

Tabela 10 - Composição do Jogo-Teste 1 com JV. . . . . . . . . . . . . . 117

Tabela 11 - Composição do Jogo-Teste 2 com JV. . . . . . . . . . . . . . 118

Tabela 12 - Poluição Global do Reservatório no Jogo-Teste 1 com JV. 118

Tabela 13 - Poluição Global do Reservatório no Jogo-Teste 2 com JV. 118

Tabela 14 - Percentual de Famílias Morando em Favelas no Jogo-Teste 1 com JV. . . . . . . . . . . . . . . . . . . . . . . . . 119

Tabela 15 - Percentual de Famílias Morando em Favelas no Jogo-Teste 2 com JV. . . . . . . . . . . . . . . . . . . . . 119

Tabela 16 - Percentual de Desemprego por Município no Jogo-Teste 1 com JV. . . . . . . . . . . . . . . . . . . . 119

Tabela 17 - Percentual de Desemprego por Município no Jogo-Teste 2 com $\mathrm{JV} . \ldots \ldots \ldots \ldots \ldots \ldots \ldots \ldots$ 
Tabela 18 - Negociações Bilaterais de Compra/Aluguel no Jogo-Teste 1 com JH na Rodada $1 . \quad$. . . . . . . . . . . . . . . . . . . 122

Tabela 19 - Negociações Bilaterais de Infra-estrutura no Jogo-Teste 1 com JH na Rodada 1. . . . . . . . . . . . . . . . . . . . . . 123

Tabela 20 - Negociações Coletivas no Jogo-Teste 1 com JH na Rodada 1. 124

Tabela 21 - Estratégias Coletivas Aceitas na Rodada 1 e Ações Executadas em Rodadas Posteriores no Jogo-Teste 1 com JH. . . . 125

Tabela 22 - Estratégias Coletivas Aceitas na Rodada 2 e Ações Executadas em Rodadas Posteriores no Jogo-Teste 1 com JH. . . . 125

Tabela 23 - Estratégias Coletivas Aceitas na Rodada 3 e Ações Executadas em Rodadas Posteriores no Jogo-Teste 1 com JH. . . . 125

Tabela 24 - Negociações Bilaterais de Compra/Aluguel no Jogo-Teste 2 com JH na Rodada 1. . . . . . . . . . . . . . . . . 127

Tabela 25 - Negociações Bilaterais de Infra-estrutura no Jogo-Teste 2 com JH na Rodada 1. . . . . . . . . . . . . . . . . . . 127

Tabela 26 - Negociações Coletivas no Jogo-Teste 2 com JH na Rodada 1. 128

Tabela 27 - Estratégias Coletivas Aceitas na Rodada 1 e Ações Executadas em Rodadas Posteriores no Jogo-Teste 2. . . . . . . . 128

Tabela 28 - Estratégias Coletivas Aceitas na Rodada 2 e Ações Executadas em Rodadas Posteriores no Jogo-Teste 2. . . . . . . . 128

Tabela 29 - Negociações Bilaterais de Compra/Aluguel no Jogo-Teste 3 com JH na Rodada 1. . . . . . . . . . . . . . . . . . . . 130

Tabela 30 - Negociações Bilaterais de Infra-estrutura no Jogo-Teste 3 com JH na Rodada 2. . . . . . . . . . . . . . . . . . . . . 130

Tabela 31 - Negociações Bilaterais Específicas do Representante dos SemTeto no Jogo-Teste 3 com JH na Rodada 2. . . . . . . . . . . . 131

Tabela 32 - Negociações Bilaterais Específicas do Representante dos SemTeto no Jogo-Teste 3 com JH na Rodada 4. . . . . . . . . . . . 131

Tabela 33 - Negociações Coletivas no Jogo-Teste 3 com JH na Rodada 1. 132

Tabela 34 - Estratégias Coletivas Aceitas na Rodada 1 e Ações Executadas em Rodadas Posteriores no Jogo-Teste 3. . . . . . . . . 132 
Tabela 35 - Estratégias Coletivas Aceitas na Rodada 2 e Ações Executadas em Rodadas Posteriores no Jogo-Teste 3. . . . . . . . . 132

Tabela 36 - Estratégias Coletivas Aceitas na Rodada 3 e Ações Executadas em Rodadas Posteriores no Jogo-Teste 3. . . . . . . . . 133

Tabela 37 - Composição Papéis e Perfis Comportamentais no Jogo-Teste 1 com JM. . . . . . . . . . . . . . . . . . . . . 135

Tabela 38 - Percentual de Serviços Urbanos no Município C no Jogo-Teste 1 com JM. . . . . . . . . . . . . . . . . . . . 137

Tabela 39 - Percentual de Desenvolvimento Social no Município C no Jogo-Teste 1 com JM. . . . . . . . . . . . . . . . . . . 137

Tabela 40 - Percentual de Desemprego para o Jogador Virtual Prefeito C no Jogo-Teste 1 com JM. . . . . . . . . . . . . . . . . 137

Tabela 41 - Poluição Global do Reservatório - Jogo-Teste 1 com JM. . . 138

Tabela 42 - Negociações Bilaterais de Compra/Aluguel no Jogo-Teste 1 com JM na Rodada 1. . . . . . . . . . . . . . . . . . . . . 138

Tabela 43 - Negociações Bilaterais de Infra-estrutura no Jogo-Teste 1 com JM na Rodada 1. . . . . . . . . . . . . . . . . . . . . 138

Tabela 44 - Negociações Coletivas no Jogo-Teste 1 com JM na Rodada 1. 139

Tabela 45 - Estratégias Coletivas Aceitas na Rodada 1 e Ações Executadas em Rodadas Posteriores no Jogo-Teste 1 com JM. . . . 140

Tabela 46 - Estratégias Coletivas Aceitas na Rodada 2 e Ações Executadas em Rodadas Posteriores no Jogo-Teste 1 com JM. . . . 140

Tabela 47 - Estratégias Coletivas Aceitas na Rodada 3 e Ações Executadas em Rodadas Posteriores no Jogo-Teste 1 com JM. . . . 140

Tabela 48 - Composição Papéis e Perfis Comportamentais no Jogo-Teste 2 com JM. . . . . . . . . . . . . . . . . . . . . . . 141

Tabela 49 - Percentual de Serviços Urbanos no Município C no Jogo-Teste 2 com JM. . . . . . . . . . . . . . . . . . . . . . . . . 142

Tabela 50 - Percentual de Serviços Urbanos no Município C no Jogo-Teste 2 com JM. . . . . . . . . . . . . . . . . . . . . . . . . 142

Tabela 51 - Percentual de Desemprego no Município C no Jogo-Teste 2 com JM. . . . . . . . . . . . . . . . . . . . . . . . . . . . . . . 143 
Tabela 52 - Poluição Global do Reservatório no Jogo-Teste 2 com JM. 143

Tabela 53 - Percentual de Famílias Morando em Favelas - Jogo-Teste 2 com JM. . . . . . . . . . . . . . . . . . . . . . . . . . . 143

Tabela 54 - Negociações Bilaterais de Compra/Aluguel no Jogo-Teste 2 com JM na Rodada 1. . . . . . . . . . . . . . . . . . . . . 144

Tabela 55 - Negociações Bilaterais de Infra-estrutura no Jogo-Teste 2 com JM na Rodada 1. . . . . . . . . . . . . . . . . . . 145

Tabela 56 - Negociações Coletivas no Jogo-Teste 2 com JM Rodada 1. 145

Tabela 57 - Estratégias Coletivas Aceitas na Rodada 1 e Ações Executadas em Rodadas Posteriores no Jogo-Teste 2 com JM. . . . 146

Tabela 58 - Estratégias Coletivas Aceitas na Rodada 2 e Ações Executadas em Rodadas Posteriores no Jogo-Teste 2 com JM. . . . 146

Tabela 59 - Estratégias Coletivas Aceitas na Rodada 3 e Ações Executadas em Rodadas Posteriores no Jogo-Teste 2 com JM. . . . 146

Tabela 60 - Composição Papéis e Perfis Comportamentais no Jogo-Teste 3 com JM. . . . . . . . . . . . . . . . . . . . . . . . . . . 148

Tabela 61 - Percentual de Serviços Urbanos no Jogo-Teste 3 com JM. . . 149

Tabela 62 - Percentuais de Famílias Conectadas a Rede de Esgoto e a Rede de Água no Jogo-Teste 3 com JM. . . . . . . . . . . . 150

Tabela 63 - Percentual de Desenvolvimento Social no Jogo-Teste 3 com JM.150

Tabela 64 - Percentual de Famílias Morando em Favelas no Jogo-Teste 3 com JM. . . . . . . . . . . . . . . . . . . . . 150

Tabela 65 - Percentual de Desemprego no Jogo-Teste 3 com JM. . . . . . 150

Tabela 66 - Poluição Global do Reservatório no Jogo-Teste 3 com JM. 150

Tabela 67 - Negociações Bilaterais de Compra/Aluguel no Jogo-Teste 3 com JM na Rodada 1. . . . . . . . . . . . . . . . . 152

Tabela 68 - Negociações Bilaterais de Infra-estrutura no Jogo-Teste 3 com JM na Rodada 2. . . . . . . . . . . . . . . . . . . 152

Tabela 69 - Negociações Bilaterais de Infra-estrutura no Jogo-Teste 3 com JM na Rodada 3. . . . . . . . . . . . . . . . . . . 153 
Tabela 70 - Negociações Bilaterais de Infra-estrutura no Jogo-Teste 3 com JM na Rodada 4. . . . . . . . . . . . . . . . . . . . . . . 153

Tabela 71 - Negociações Bilaterais Específicas do Representante dos SemTeto no Jogo-Teste 3 com JM na Rodada 1. . . . . . . . . . . . 153

Tabela 72 - Negociações Bilaterais Específicas do Representante dos SemTeto no Jogo-Teste 3 com JM na Rodada 2. . . . . . . . . . . . 153

Tabela 73 - Negociações Bilaterais Específicas do Representante dos SemTeto no Jogo-Teste 3 com JM na Rodada 4. . . . . . . . . . . . . 153

Tabela 74 - Negociações Coletivas no Jogo-Teste 3 com JM na Rodada 1. 154

Tabela 75 - Estratégias Coletivas Aceitas na Rodada 1 e Ações Executadas em Rodadas Posteriores no Jogo-Teste 3 com JM. . . . 154

Tabela 76 - Estratégias Coletivas Aceitas na Rodada 2 e Ações Executadas em Rodadas Posteriores no Jogo-Teste 3 com JM. . . . 154

Tabela 77 - Estratégias Coletivas Aceitas na Rodada 3 e Ações Executadas em Rodadas Posteriores no Jogo-Teste 3 com JM. . . . 155

Tabela 78 - Quantidade de Negociações Bilaterais e Coletivas nos JH e JM. . . . . . . . . . . . . . . . . . . . . . 159 


\section{Lista de Abreviaturas}

ACL Agent Communication Language

ACT-R Adaptive Character of Thought

BDI Belief-Desire-Intention

CNP Contract Net Protocol

COGNET COGnition as a NEtwork of Tasks

GMABS Games and Multi-Agent-Based Simulation

GPS General Problem Solver

IA Inteligência Artificial

JASON Java-based AgentSpeak intepreter used with Saci for multi-agent distribution Over the Net

JV Jogos Exclusivamente com Jogadores Virtuais

JH Jogos Exclusivamente com Jogadores Humanos

JM Jogos com Jogadores Mistos

KQML Knowledge Query and Manipulation Language

MABS Multi-Agent-Based Simulation

ONG Organização Não-Governamental

RPGs Role-Playing Games

SACI Simple Agent Communication Infrastructure

SADs Sistemas de Apoio à Decisão

SADs-G Sistemas de Apoio à Decisão em Grupos

SMAs Sistemas Multiagentes

SOAP Simple Object Access Protocol

ViP-GMABS Virtual Players in Games and Multi-Agent-Based Simulation

XML Extensible Markup Language 


\section{Sumário}

1 Introdução 1

1.1 Motivação . . . . . . . . . . . . . . . . . . . . . 3

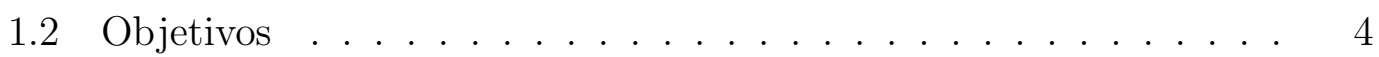

1.3 Metodologia Adotada . . . . . . . . . . . . . 5

1.4 Contribuições Esperadas . . . . . . . . . . . . . . . . 7

1.5 Organização do Texto . . . . . . . . . . . . . . . 7

\section{Fundamentos Básicos}

2 Técnicas e Tecnologias Utilizadas 10

2.1 Simulação Baseada em Multiagentes (MABS) . . . . . . . . . . . 10

2.2 Jogos de Papéis $(\mathrm{RPGs}) \ldots \ldots \ldots$

2.3 Sistemas de Apoio à Decisão em Grupos (SADs-G) . . . . . . . . 17

2.3.1 Apoio à Decisão na Gestão de Recursos

Naturais . . . . . . . . . . . . . . . . . . . . . 19

2.3.2 Metodologia GMABS . . . . . . . . . . . . 20

2.4 Jogadores Virtuais . . . . . . . . . . . . . . . . . . . 23

2.4.1 Arquiteturas Cognitivas para Agentes . . . . . . . . . . 24

2.4.2 Protocolos de Negociação . . . . . . . . . . . . . . . 31

2.5 Considerações Finais . . . . . . . . . . . . . . . . . . . 35

3 Uso de MABS e RPG em Gestão de Recursos Naturais 36

3.1 Desafio das Águas . . . . . . . . . . . . . . . . . . . . . . 36

3.2 SHADOC . . . . . . . . . . . . . . . . . 37 
3.3 SAMBA-Week . . . . . . . . . . . . . . . . . . . 39

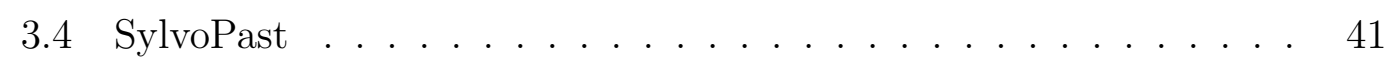

3.5 Análise Comparativa . . . . . . . . . . . . . . . 42

3.6 Considerações Finais . . . . . . . . . . . . . . . . . . 43

4 Avaliação de Sistemas Computacionais $\quad 44$

4.1 Métodos de Avaliação . . . . . . . . . . . . . . . . . 44

4.1.1 Métodos Baseados na Etnografia . . . . . . . . . . 45

4.1.2 Métodos Baseados na Psicologia . . . . . . . . . . 46

4.1.3 Métodos Baseados na Construção de Sistemas . . . . . . . 47

4.1 .4 Análise Comparativa . . . . . . . . . . . . . . 48

4.2 Aplicação dos Métodos em Áreas Correlacionadas . . . . . . . . . 49

4.3 Considerações Finais . . . . . . . . . . . . . . . . . 53

\section{Abordagem Proposta}

5 Protótipo JogoMan $\quad 55$

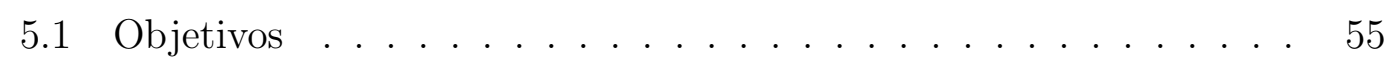

5.2 Descrição Detalhada . . . . . . . . . . . . . . . 56

5.2 .1 Papéis Existentes . . . . . . . . . . . . . 56

5.2 .2 Tipos de Uso do Solo . . . . . . . . . . . . . . . . 58

$5.2 .3 \quad$ Variáveis . . . . . . . . . . . . . . . . 58

5.2 .4 Funcionamento . . . . . . . . . . . . . 61

5.2.5 Tipos de Negociação . . . . . . . . . . . . . . . 63

5.3 Análise dos Jogos Realizados . . . . . . . . . . . . . . . . . . 64

5.3.1 Mapeamento das Estratégias dos Jogadores . . . . . . . 65

5.3.2 Questionários Aplicados aos Jogadores . . . . . . . . . . 67

5.4 Considerações Finais . . . . . . . . . . . . . . . . . . 70 
6.1 Motivação . . . . . . . . . . . . . . . . . . 72

6.2 Arquitetura Genérica . . . . . . . . . . . . . . . 73

6.3 Arquitetura Cognitiva dos Jogadores Virtuais . . . . . . . . . 75

6.4 Considerações Finais . . . . . . . . . . . . . . . . . . 77

$\begin{array}{lll}7 & \text { Perfis para os Jogadores Virtuais } & 78\end{array}$

7.1 Perfis Comportamentais . . . . . . . . . . . . 78

7.1.1 Proprietários Particulares . . . . . . . . . . 79

7.1.2 Administrador da Companhia de Água (AGUAPURA) . . 80

7.1.3 Prefeitos ........................ 81

7.1.4 Representante dos SemTeto ............. . 82

7.2 Comentários sobre os Perfis . . . . . . . . . . . 83

7.3 Considerações Finais . . . . . . . . . . . . . . . 86

8 Protótipo ViP-JogoMan $\quad 88$

8.1 Visão Geral . . . . . . . . . . . . . . . . . . . . 88

8.2 Ferramenta MABS: Cormas . . . . . . . . . . . . . . . 90

8.3 Arquitetura Cognitiva dos Jogadores Virtuais . . . . . . . . . 91

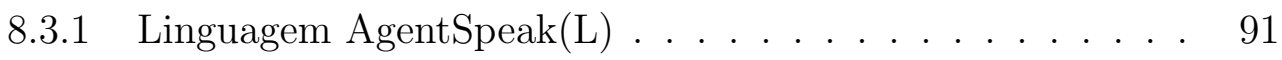

8.3.2 Interpretador Jason . . . . . . . . . . . . . . . . 92

8.3.3 Protocolo de Negociação . . . . . . . . . . . . . . . . . . 94

8.4 Interfaces dos Jogadores Reais _ . . . . . . . . . . . . . . . . . . 99

8.5 Camada de Comunicação: Protocolo SOAP e SACI . . . . . . . . 104

8.5.1 Protocolo SOAP . . . . . . . . . . . . . . 104

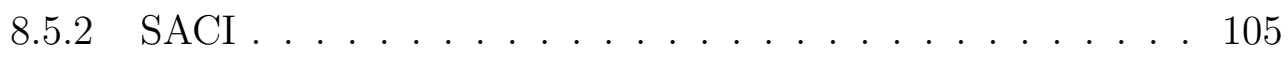

8.6 Considerações Finais . . . . . . . . . . . . . . . . 106 


\section{Resultados Obtidos}

9 Metodologia para Avaliação do Protótipo ViP-JogoMan 109

9.1 Escopo da Avaliação . . . . . . . . . . . . . . . . . . . . . . . . 109

9.2 Avaliação dos Perfis Comportamentais . . . . . . . . . . . . . . 111

9.3 Questionários aos Jogadores Reais _. . . . . . . . . . . . 112

9.4 Análise de Trocas de Mensagens entre os Jogadores . . . . . . . . 113

9.5 Considerações Finais . . . . . . . . . . . . . . . . . . 115

10 Testes e Avaliação no Protótipo ViP-JogoMan 116

10.1 Jogos Exclusivamente com Jogadores Virtuais (JV) . . . . . . . 117

10.1.1 Jogos-Teste com JV . . . . . . . . . . . . . . . . 117

10.1.2 Análise dos Jogos-Teste com JV . . . . . . . . . . . 120

10.2 Jogos Exclusivamente com Jogadores Humanos (JH) . . . . 120

10.2.1 Jogo-Teste 1 com JH . . . . . . . . . . . . . . . 121

10.2.2 Jogo-Teste 2 com JH . . . . . . . . . . . . . . . 125

10.2.3 Jogo-Teste 3 com JH . . . . . . . . . . . . . . . . 129

10.2.4 Análise dos Jogos-Teste com JH . . . . . . . . . . . . 133

10.3 Jogos com Jogadores Mistos (JM) _ . . . . . . . . . . . 134

10.3.1 Jogo-Teste 1 com JM . . . . . . . . . . . . . . . . 135

10.3.2 Jogo-Teste 2 com JM . . . . . . . . . . . . . . 141

10.3.3 Jogo-Teste 3 com JM . . . . . . . . . . . . . . . 147

10.3.4 Análise dos Jogos-Teste com JM . . . . . . . . . . . . . 155

10.4 Considerações Finais . . . . . . . . . . . . . . . . . . 158

$\begin{array}{ll}11 \text { Conclusões } & 160\end{array}$

11.1 Contribuições . . . . . . . . . . . . . . . . . . . . . 160

11.2 Trabalhos Futuros . . . . . . . . . . . . . . . . 163 
Referências Bibliográficas 


\section{Introdução}

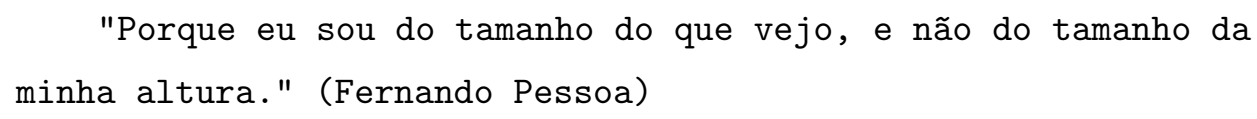

O objetivo desta tese é construir uma arquitetura para incorporar jogadores virtuais em uma classe de Sistemas de Apoio à Decisão em Grupos (SADs-G), baseada na utilização conjunta de Simulação Baseada em Multiagentes (MABS) e Jogos de Papéis (RPGs). Esta classe, denominada GMABS, e a extensão desta classe com a incorporação de jogadores virtuais, denominada ViP-GMABS, serão aplicadas no domínio de Gestão de Recursos Naturais.

Jogo de Papéis (Role-Playing Games (RPGs)) é um tipo de jogo onde os jogadores "interpretam" uma personagem, criada dentro de um determinado cenário (ambiente). As personagens respeitam um sistema de regras, que serve para organizar suas ações, determinando os limites do que pode ou não ser feito (KLIMICK, 2003). RPG é uma técnica muito utilizada em treinamento, pois pode colocar os jogadores em situações de tomada de decisão similares às reais, porém sem conseqüências efetivas. Em especial, grandes empresas têm utilizado RPG em cursos de treinamento devido ao fator lúdico envolvido nos jogos, o que faz com que o treinamento e/ou aprendizagem de determinado assunto seja facilitado.

Já os chamados Sistemas Multiagentes (SMAs) estudam o comportamento de um conjunto de agentes autônomos, eventualmente com características diferentes, que evoluem em um ambiente comum (ALVARES; SICHMAN, 1997). Estes agentes interagem uns com os outros, com o objetivo de realizar suas tarefas de modo cooperativo, compartilham informações, evitam conflitos e coordenam a execução de atividades (BITTENCOURT, 1998). Para o desenvolvimento destes agentes, é necessária a utilização de arquiteturas, visto que estas definem a organização interna de cada agente e como são estruturados seus relacionamentos e interações. As arquiteturas para agentes aqui enfatizadas são as que buscam modelar o raciocínio humano (modelos cognitivos), onde têm-se como exemplo as arquiteturas BDI (RAO; GEORGEFF, 1995) e SOAR (LAIRD; NEWELL; ROSEN- 
BLOOM, 1987).

Adicionalmente, a utilização da simulação como elemento auxiliar na tomada de decisões humanas é muito eficaz, pois seu emprego permite o exame de detalhes específicos com grande precisão (STRACK, 1984). Da integração das tecnologias de agentes e de simulação, surgiu a área de Simulação Baseada em Multiagentes (Multi-Agent-Based Simulation (MABS)), que é especialmente útil em domínios onde a interdisciplinaridade se faz presente (GILBERT; TROITZSCH, 1999). Um destes domínios é a gestão de recursos naturais, área pública de extrema importância, que atualmente vem chamando muita atenção de diversos órgãos de pesquisa e de instituições públicas e privadas. Tal gestão pode ser considerada um problema complexo, visto que abrange diversas áreas de conhecimento e pesquisa, como sociologia, hidrologia e biologia. A utilização de MABS e RPG (de forma isolada ou até mesmo combinada) tem sido utilizada em diversos trabalhos relacionados ao gerenciamento de recursos naturais (EDMONDS; BARTHELEMY; MOSS, 2002; D'AQUINO et al., 2003; BARRETEAU, 2003; BARRETEAU et al., 2004; DARE; BARRETEAU, 2004; GUYOT; HONIDEN, 2006; GUYOT; DROGOUL; HONIDEN, 2006; BRIOT; GUYOT; IRVING, 2007), e pode trazer resultados interessantes, pois une a capacidade dinâmica de MABS com a capacidade de discussão e aprendizado das técnicas de RPG. A utilização integrada das técnicas de RPG e MABS será denominada neste trabalho de Games and Multi-Agent-Based Simulation (GMABS).

Os chamados Sistemas de Apoio à Decisão (SADs) são sistemas de informação, que fornecem dados sobre o domínio do problema em estudo e contribuem para o processo de tomada de decisão humana (DORNELAS, 2000). Um sub-grupo dos SADs são os Sistemas de Apoio à Decisão em Grupos (SADs-G), onde o enfoque está em trabalhar a tomada de decisão para grupos de pessoas. No trabalho cooperativo, normalmente, existem problemas de coordenação e tempo consumido para executar as tarefas. Sistemas implementados a partir da metodologia GMABS são uma classe de SADs-G.

Quando um RPG é realizado, este necessita de um certo número de jogadores reais para ser executado. Contudo, muitas vezes o jogo não pode ser realizado, mesmo estando os jogadores em locais diferentes (se o jogo é realizado via $W e b$, por exemplo) e/ou em tempos diferentes (se for realizado de forma assíncrona), pois não há o número mínino necessário de jogadores para sua realização. Desta maneira, seria muito útil a existência de Jogadores Virtuais, que possam substituir alguns jogadores reais sem causar danos ao jogo. Entende-se por danos ao jogo uma situação na qual outros jogadores reais conseguem identificar facilmente 
quais foram as decisões dos jogadores virtuais, ou seja, as decisões tomadas pelos jogadores virtuais não são verossímeis.

Desta forma, a proposta desta tese é desenvolver uma arquitetura onde jogadores virtuais possam ser inseridos na metodologia GMABS, denominada ViPGMABS, para simular processos de tomada de decisão em um SADs-G, no contexto de gestão de recursos naturais.

\subsection{Motivação}

A Gestão de Recursos Naturais é um tópico que se refere a grandes áreas (físicas) de trabalho e pesquisa, como cidades, estados, etc., onde todo o ecossistema deve ser analisado. Além do fato das dimensões das regiões envolvidas serem grandes, deve-se considerar ainda a existência de uma grande diversidade de atores, com objetivos e estratégias diferentes. Por exemplo, o estudo dos problemas de água na Região Metropolitana de São Paulo é bastante complicado, pois trata-se de uma região que abrange aproximadamente $8.000 \mathrm{Km}^{2}$ de área, sendo que mais de $1.500 \mathrm{Km}^{2}$ desta área é povoada por aproximadamente 18 milhões de habitantes. Deve ficar claro, porém, que a participação de todos os atores no processo de gestão é praticamente impossível, sendo necessário definir representantes de grupos participativos da sociedade civil, órgãos públicos, ONGs, etc. (DORAN, 2001).

A problemática está na organização do processo de negociação entre estes atores, visto que, tendo objetivos e estratégias diferentes, normalmente ocorrem conflitos e o conhecimento não é comum entre eles. Para iniciar qualquer negociação, é necessário que os atores estejam "falando a mesma língua", ou seja, é necessário que exista um dicionário comum, com termos, definições, etc. Um bom exemplo é colocar um agricultor e um industrial conversando: eles não entrarão em consenso facilmente, pois seus objetivos geram conflito de interesses. Depois de iniciado o processo de negociação, as possíveis soluções podem divergir entre grupos de atores, ou seja, uma boa solução para alguns pode não o ser para outros. Para auxiliar esse processo, é necessária a utilização de sistemas de apoio à decisão, que possam ajudar a solucionar a divergência de conhecimentos e conflitos entre as soluções.

No domínio da gestão de recursos naturais, tanto MABS quanto RPG têm sido utilizados para desenvolver sistemas de apoio à decisão (BARRETEAU; BOUSQUET; ATTONATY, 2001; BOUSQUET et al., 1999; BOISSAU; CASTELLA, 2003; DUCROT et 
al., 2004; GUYOT; DROGOUL; LEMAîTRE, 2005). Contudo, os cenários definidos para RPGs na gestão de recursos naturais normalmente necessitam de um grande número de jogadores. Mesmo sendo o jogo uma abstração de um problema específico, este exige um número mínimo de jogadores e regras para que o grau de abstração não seja tão alto, de modo a oferecer um auxílio ao entendimento do processo de negociação real. Desta forma, após a realização de alguns testes utilizando GMABS, verificou-se a necessidade de alguma ferramenta que pudesse substituir os jogadores reais, caso o número mínimo necessário de jogadores reais não fosse atingido. A idéia de criação de jogadores virtuais, além de substituir os jogadores reais, poderá ajudar a "forçar" uma determinada situação. Por exemplo, para o domínio de gestão de recursos naturais, se os jogadores virtuais tiverem como objetivo a melhoria da qualidade da água, estes podem escolher não desmatar as florestas. Esta ação pode ser vista pelos outros jogadores, que perceberão os impactos desta ação sobre o cenário, ou seja, a melhoria da qualidade da água. Assim, a existência de jogadores virtuais, que tenham tomada de decisão verossímil e possam se comunicar com os outros jogadores (reais e/ou virtuais), é uma ferramenta bastante útil no contexto da metodologia GMABS.

\subsection{Objetivos}

O objetivo principal deste trabalho é conceber e implementar uma arquitetura onde jogadores virtuais possam ser utilizados na metodologia GMABS, para auxiliar processos de tomada de decisão em grupos no contexto de gestão de recursos naturais. Espera-se que estes jogadores virtuais tenham um comportamento parecido com os comportamentos dos jogadores reais e/ou que possam apresentar novas visões do jogo, de forma a estimular novas situações aos jogadores reais. Para alcançar este objetivo, as seguintes atividades são necessárias:

- Definição da arquitetura global, denominada ViP-GMABS, onde jogadores reais e virtuais poderão, simultaneamente, coexistir;

- Definição de uma arquitetura cognitiva para cada jogador virtual, de forma que seus comportamentos possam ser descritos de forma não-trivial, ou seja, com raciocínio parecido aos dos jogadores reais durante o RPG;

- Implementação desta arquitetura no contexto de gestão de recursos naturais, de forma a validá-la. 
Esta tese está inserida no Projeto Negowat ${ }^{1}$ (Facilitating Negotiations Over Land and Water Conflicts in Latin American Peri-Urban Upstream Catchments: Combining Multi-Agent Modelling with Role-Playing Games), que utiliza uma combinação de MABS e RPG, aplicada no contexto de resolução e negociação de conflito para o gerenciamento de água e de solo em bacias peri-urbanas de regiões metropolitanas (DUCROT et al., 2003)² . Existem duas áreas de estudo na região metropolitana de São Paulo (sub-bacias Alto-Tietê/Cabeceiras e Guarapiranga) e ainda uma terceira área localizada na região de Cochabamba, na Bolívia. A coordenação geral do projeto é do CIRAD (França) e o objetivo principal é desenvolver e testar sistemas de apoio à decisão em grupo na gestão sobre água e solo em áreas peri-urbanas.

Dentro deste contexto, os dois protótipos implementados nesta tese como estudo de caso foram desenvolvidos no escopo do projeto Negowat. Sem as informações repassadas pelos especialistas do projeto (como biólogos, agrônomos, antropólogos e engenheiros químicos), a definição dos protótipos para este domínio seria inviável, visto que a área de gestão de recursos naturais é bastante complexa.

\subsection{Metodologia Adotada}

Conforme será melhor detalhado na seção 2.3.2, uma etapa importante na metodologia GMABS é a inserção dos dados referentes às ações escolhidas pelos jogadores numa rodada do RPG no sistema MABS. Tipicamente, tal função pode ser executada por um operador humano ou de modo automático.

Como no contexto desta tese deseja-se desenvolver jogadores virtuais, poderão portanto existir três tipos distintos de jogos, de acordo com a composição dos jogadores.

A combinação destes dois aspectos encontra-se representada na Tabela 1. Nesta tabela, verifica-se que, das seis possíves combinações, apenas quatro possuem instâncias de jogos: quando houver jogadores virtuais envolvidos, o processo de inserção dos dados no MABS será sempre automático, pois não é necessário um operador humano para esta atividade.

Para que todas as possíveis combinações pudessem ser analisadas, as quatro

\footnotetext{
${ }^{1}$ Comissão Européia Proc. N. ICA4-CT-2002-10061 e FAPESP Proc. N. 2002/09817-5.

${ }^{2}$ Este é um projeto de pesquisa interdisciplinar que agrega diversas instituições de pesquisa nacionais e internacionais, dentre delas, diversas unidades da USP, como EP (Escola Politécnica), PROCAM (Programa de Pós-Graduação em Ciência Ambiental), IAG (Instituto de Astronomia e Geofísica) e FSP (Faculdade de Saúde Pública). Mais detalhes sobre o projeto podem ser encontrados em http://www.negowat.org.
} 


\begin{tabular}{|c|c|c|c|}
\hline \hline & Pessoas & Jog.Virtuais & Pessoas e Jog.Virtuais \\
\hline \hline Operador & Jogos de & & \\
Humano & Mesa & - & Jogos \\
\hline & Jogos & Jogos & com Jogadores \\
Processo & Exclusivamente & Exclusivamente & Mistos (JM) \\
Automático & com Jogadores & com Jogadores & \\
& Humanos (JH) & Virtuais (JV) & \\
\hline \hline
\end{tabular}

Tabela 1: Combinação Entre os Tipos de Jogadores e a Forma de Inserção dos Dados no sistema MABS.

instâncias de jogos definidas pela Tabela 1 foram implementadas e testadas. A seqüência de atividades adotada para implementar estas instâncias de jogos e alcançar os objetivos propostos anteriormente são:

1. Estudo das técnicas MABS e RPG e da metodologia GMABS;

2. Definição, implementação e testes de uma instância de um Jogo de Mesa, para um melhor entendimento da metodologia GMABS;

3. A partir dos testes realizados em Jogos de Mesa, verificou-se a necessidade de alguma forma computacional que suprisse a falta de jogadores para realização dos jogos. Desta maneira, definiu-se a arquitetura denominada ViP$G M A B S$, onde jogadores virtuais estão inseridos na metodologia GMABS;

4. Definição de perfis comportamentais para os jogadores virtuais, de forma que estes jogadores tenham tomada de decisão não-trivial;

5. Definição, implementação e testes de uma instância de um Jogo Exclusivamente com Jogadores Virtuais $(J V)$, com intuito de testar se os perfis comportamentais definidos para os jogadores virtuais eram adequados;

6. Definição, implementação e testes de uma instância de um Jogo Exclusivamente com Jogadores Humanos (JH), de forma a verificar se o uso da tecnologia interfere na forma como as pessoas interagem umas com as outras durante os processos de negociação;

7. Definição, implementação e testes de uma instância de um Jogo com Jogadores Mistos (JM), de forma a verificar se os jogadores virtuais têm tomada de decisão similar à dos jogadores reais e se estes jogadores interagem de forma ampla e completa com todos os outros jogadores. 


\subsection{Contribuições Esperadas}

O desenvolvimento de ferramentas de apoio à decisão utilizando a metodologia GMABS mostra-se uma atividade bastante promissora. A inserção de jogadores virtuais utilizando esta metodologia ainda é algo bastante novo e pouco estudado e analisado. Desta maneira, as contribuições desta tese envolvem o melhor entendimento do uso de jogadores virtuais utilizando a metodologia GMABS.

O protótipo desenvolvido, a partir da arquitetura proposta, deve responder a algumas perguntas, que são fundamentais para o entendimento e utilização de jogadores virtuais em GMABS:

- Como podem ser definidos os comportamentos de cada jogador virtual, de forma que estes tenham tomada de decisão parecida com a dos jogadores reais?

- Diversos trabalhos mostram a capacidade de discussão e aprendizado de técnicas de RPG (BARRETEAU et al., 2004; D'AQUINO et al., 2003; DARE; BARRETEAU, 2004; GUYOT; DROGOUL, 2005). Com a inserção de jogadores virtuais, esta capacidade continuará ativa? As negociações e interações para tomada de decisão continuarão ocorrendo entre os jogadores reais e/ou virtuais?

- O protótipo será implementado para ser jogado via Web. Esta forma de jogo (remota) dificultará as interações entre os jogadores reais e/ou virtuais? Haverá dificuldade dos jogadores reais de interagir com o sistema, como problemas de interface ou demora na execução das ações remotas?

\subsection{Organização do Texto}

O texto a seguir está distribuído em três partes. Na primeira parte são apresentados, de forma resumida, os fundamentos básicos deste trabalho. $\mathrm{Na}$ segunda parte, a abordagem adotada para a proposta desta tese é formulada e os detalhes de sua implementação são apresentados. Na terceira parte, são apresentados os resultados obtidos nos testes realizados a partir da arquitetura proposta.

A primeira parte é formada pelos capítulos 2,3 e 4 . No capítulo 2, são apresentadas as técnicas e tecnologias básicas utilizadas neste trabalho: Simulação Baseada em Multiagentes (MABS), Jogos de Papéis (RPG), Sistemas Apoio à 
Decisão em Grupos (SADs-G) e Jogadores Virtuais. Já o capítulo 3 apresenta alguns exemplos de aplicação destas técnicas em gestão de recursos naturais. No capítulo 4, são discutidos os métodos de avaliação de sistemas computacionais existentes na literatura e exemplos de sua aplicação dentro do escopo deste trabalho.

A segunda parte é formada pelos capítulos 5, 6, 7 e 8. O capítulo 5 apresenta o protótipo JogoMan, desenvolvido utilizando a metodologia GMABS, bem como os testes realizados neste protótipo. O capítulo 6 detalha a arquitetura proposta neste trabalho, ViP-GMABS, definindo os requisitos necessários para sua implementação. O capítulo 7 define os perfis comportamentais para os jogadores virtuais. No capítulo 8, o protótipo ViP-JogoMan, que utiliza a arquitetura ViP-GMABS, é detalhado, enfatizando-se as ferramentas escolhidas e interfaces implementadas.

A terceira parte é formada pelos capítulos 9 e 10. O capítulo 9 apresenta a metodologia de avaliação utilizada para os testes no protótipo ViP-JogoMan. No capítulo 10, são apresentados os testes realizados neste protótipo, bem como a análise dos resultados obtidos.

Finalmente, o capítulo 11 apresenta as principais conclusões e contribuições deste trabalho. Também são sugeridos alguns possíveis trabalhos futuros decorrentes da pesquisa realizada.

Adicionalmente, para um melhor entendimento dos experimentos realizados, 5 anexos são fornecidos num CD adicional ${ }^{3}$. No Anexo A, são apresentadas as respostas fornecidas pelos jogadores aos questionários pré-jogo e pós-jogo que foram distribuídos durante sessões do protótipo JogoMan (Jogo de Mesa). No Anexo B, são mostrados os dados extraídos dos testes durante sessões do protótipo JogoMan, que foram convenientemente combinados para gerar as estratégias correspondentes aos perfis comportamentais dos jogadores reais, que posteriormente serviram de base aos jogadores virtuais, conforme detalhado no capítulo 7 . A definição das justificativas das negociações bilaterais, bem como das estratégias coletivas, no âmbito do protótipo ViP-JogoMan, são respectivamente descritas nos Anexos C e D. Finalmente, o Anexo E apresenta um conjunto completo de dados extraídos dos jogos realizados no protótipo ViP-JogoMan, incluindo os questionários pré-jogo e pós-jogo fornecidos pelos jogadores reais e o arquivo de "log" com todas as negociações realizadas entre todos os jogadores.

\footnotetext{
${ }^{3}$ Optou-se por não incluir estes anexos no texto devido ao grande volume de dados/páginas adicionais que seriam necessários.
} 


\section{Parte I}

\section{Fundamentos Básicos}




\section{Técnicas e Tecnologias Utilizadas}

Este trabalho envolve três grandes áreas de conhecimento: Simulação Baseada em Multiagentes (Multi-Agent-Based Simulation (MABS)), Jogos de Papéis (RolePlaying Games (RPGs)) e Sistemas de Apoio à Decisão em Grupos (SADs-G), especificamente na área de Gestão de Recursos Naturais, que serão respectivamente apresentados nas seções 2.1, 2.2 e 2.3 .

Além destas três grandes áreas de conhecimento, ainda é necessário definir o que são jogadores virtuais no contexto deste trabalho e qual será a base teórica aplicada para definição destes jogadores, o que será discutido na seção 2.4. As considerações finais deste capítulo serão mostradas na seção 2.5.

\subsection{Simulação Baseada em Multiagentes (MABS)}

Os chamados Sistemas Multiagentes (SMAs) estudam o comportamento de um conjunto de agentes autônomos com diferentes características, evoluindo em um ambiente comum. Estes agentes interagem uns com os outros, com o objetivo de realizar suas tarefas de modo cooperativo, compartilhando informações, evitando conflitos e coordenando a execução de atividades (ALVARES; SICHMAN, 1997; BITTENCOURT, 1998; ANTUNES L. BALSA; COELHO, 2007). Uma visão atual sobre o uso da tecnologia de agentes na academia e na indústria pode ser encontrada em (LUCK; MCBURNEY; PREIST, 2003).

Modelar um fenômeno sob a perspectiva de um SMAs pode ser realizado a partir das seguintes etapas (FROZZA, 1997):

- Decompor o fenômeno em um conjunto de elementos autônomos;

- Modelar cada um dos elementos como um agente, definindo seu conhecimento, funções, comportamento e modos de interação;

- Definir o ambiente dos agentes; 
- Definir quais agentes possuem a capacidade de ação e comunicação.

Geralmente, os agentes de um SMAs são classificados em duas categorias (FERBER, 1999):

- Reativos: funcionam segundo um modelo estímulo-resposta; não possuem uma representação explícita de seu ambiente; não possuem memória das ações executadas no passado e nem previsão das ações a serem executadas no futuro. Eles apenas reagem às modificações do ambiente e não existe relação social entre os agentes.

- Cognitivos: possuem uma representação explícita de seu ambiente, de outros agentes e deles mesmos. São baseados nos modelos humanos, possuem raciocínio (estado mental ${ }^{1}$ ) e capacidade de planejamento de suas ações.

Já os métodos de simulação são empregados com grande sucesso como elemento auxiliar na tomada de decisões, principalmente no planejamento a médio e longo prazo e em situações que envolvem custos e riscos elevados. Os modelos de simulação são muito eficazes e versáteis no estudo dos mais diferentes problemas. Seu emprego permite o exame de detalhes específicos com grande precisão (REBONATTO, 1999).

Assim, a simulação baseada em computador é uma das ferramentas mais poderosas disponíveis nos dias de hoje para projetar, planejar, controlar e avaliar novas alternativas e/ou mudanças de estratégias em sistemas no mundo real. Sua utilização significa construir programas de computador (software) que 'representem' o sistema do mundo real em questão e 'imitem' seu funcionamento (GILBERT; TROITZSCH, 1999; REBONATTO, 1999). A simulação pode ser dividida em três etapas (STRACK, 1984):

- Etapa da Modelagem: construir o modelo do fenômeno a ser estudado;

- Etapa de Experimento: aplicar variações sobre o modelo construído, alterando parâmetros que influam no processo de resolução;

- Etapa de Validação: comparar dados experimentais obtidos com o modelo e a realidade, permitindo a análise dos resultados obtidos.

\footnotetext{
${ }^{1}$ Estados Mentais são representações mentais que estão dirigidas para objetos ou "coisas" no mundo (HUBNER, 2003).
} 
Pela Figura 1, pode-se verificar as etapas de um processo de simulação. A partir da realidade, é realizada uma modelagem do problema desejado e é construído um modelo. Para se construir este modelo, têm-se como base uma teoria. Com o modelo, realiza-se a simulação e depois a avaliação do mesmo. Para a avaliação, utilizam-se os resultados obtidos pelo modelo e as observações da realidade (DROGOUL; FERBER, 1992).

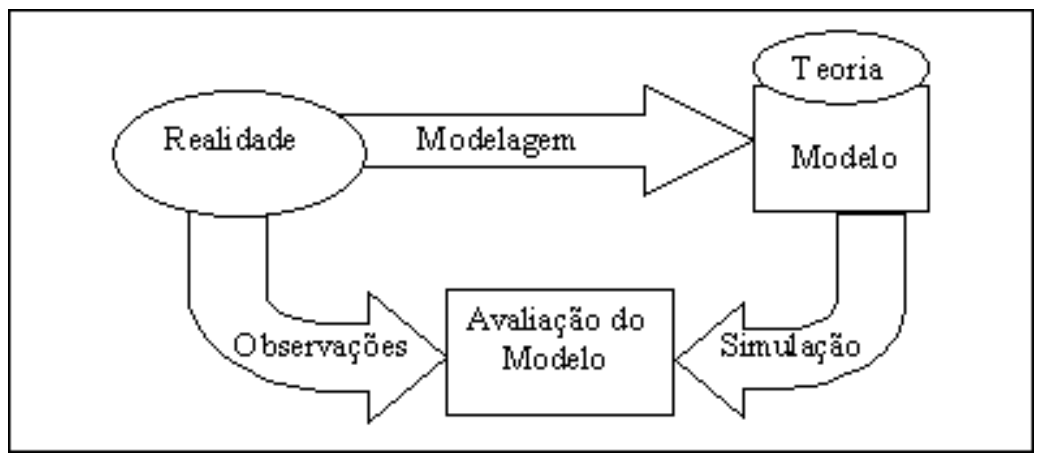

Figura 1: Etapas de um Processo de Simulação (DROGOUL; FERBER, 1992).

Da união das tecnologias de Simulação e Sistemas Multiagentes, surge a área de Simulação Baseada em Multiagentes (MABS). Muitas aplicações em SMAs são desenvolvidas para simular alguma situação da realidade. Para tal, o fenômeno real é decomposto em um conjunto de elementos e em suas interações. Cada elemento é modelado como um agente e o modelo geral é o resultado das interações entre estes agentes.

Segundo Drogoul e Ferber (DROGOUL; FERBER, 1992), os objetivos de MABS são:

- Testar hipóteses sobre a emergência de comportamentos no nível macro a partir de interações no nível micro;

- Construir teorias que contribuam para o entendimento de fenômenos, etológicos, sociológicos ou psico-sociais, que relacionam comportamentos a estruturas;

- Integrar teorias parciais de diferentes disciplinas (sociologia, psicologia cognitiva, etologia) numa mesma estrutura.

As principais características da simulação multiagentes, comparativamente à simulação matemática e/ou estatística, são (DROGOUL; FERBER, 1992):

- Criação de mundos artificiais, repletos de indivíduos, biológicos ou sociológicos, que interagem; 
- Cada indivíduo é representado por um agente (processo ou procedimento computacional);

- Um agente é capaz de produzir ações locais em resposta a estímulos externos e comunicações com outros agentes;

- Este tipo de simulação também é chamada de simulação micro-analítica.

Outros aspectos importantes em MABS são (DROGOUL; FERBER, 1992):

- É uma técnica bastante adequada para situações onde existem muitos indivíduos, com comportamentos diversos e complexos;

- Pode-se levar em conta tanto aspectos quantitativos como aspectos qualitativos;

- Programam-se os comportamentos primitivos de cada indivíduo e o comportamento global que emerge das interações entre os indivíduos é analisado, mas não pré-programado de modo direto.

Existem diversos simuladores baseados em sistemas multiagentes, como Cormas (CORMAS, 2006), SWARM (MINAR et al., 1996; DANIELS, 2006), MadKit (GUTKNECHT; FERBER, 2006) e SeSAM (KLUEGL; OECHLEIN; PUPPE, 2006). Alguns destes simuladores foram desenvolvidos para áreas específicas, como SWARM (simulações de colônias de insetos) ou Cormas (simulações na área de recursos naturais).

Para Doran (DORAN, 2001), MABS é uma grande promessa para habilitar a sociedade ao trabalho com modelos computacionais, de forma a avaliar os impactos cognitivos de sistemas sociais, tanto no âmbito individual quanto no coletivo.

\subsection{Jogos de Papéis (RPGs)}

Na literatura, existem diversas definições para jogos. Segundo o Dicionário Básico de Filosofia (JAPIASSU; MARCONDES, 1996) a definição de "jogo" é:

"Jogo: é uma atividade ou ocupação voluntária (podendo ser física ou mental), exercida dentro de limites determinados de tempo e espaço, segundo regras livremente criadas, mas absolutamente obrigatórias, dotado de um fim em si mesmo, e cuja finalidade é recreação." 
Os elementos que caracterizam os jogos, segundo Costikyan (COSTIKYAN, 1994) são:

- Possuem Objetivos e Regras bem definidos;

- Exigem Tomada de Decisão dos jogadores, para que o jogo tenha continuidade;

- Existe um elemento de Conflito gerado pelas regras, de forma a alcançar os objetivos propostos;

- Os jogadores são obrigados a administrar Recursos, como cartas que recebem baixo valor e podem ser descartadas;

- Os jogadores podem Manipular diretamente os elementos (cartas, peças, etc.) do jogo de forma a haver interação;

- Envolvem a participação dos jogadores, ou seja, possuem Interação.

Os jogos podem ser classificados de diversas formas, como Jogos de Peças ou Jogos de Cartas. Porém, neste trabalho a ênfase está nos Jogos Computacionais que são uma simulação de algum mecanismo ou situação, que pode ou não existir no mundo real, a partir de um dispositivo computacional. Os jogos computacionais diferem de outros softwares pela sua subjetividade, pois seu primeiro objetivo é divertir (essa diversão pode vir associada a outros objetivos, como educar, treinar e selecionar). Mesmo que o jogo seja baseado em um jogo real totalmente determinístico, existe a subjetividade, visto que a interface e o nível de características deste jogo se baseiam na concepção do criador e são ajustados a um público-alvo de usuários (CARVALHO, 2004).

A área de jogos computacionais e a área de Inteligência Artificial (IA) têm longa tradição de cooperação. Os jogos proporcionam à IA uma variedade de problemas a serem solucionados e com um grande desafio de, normalmente, requerer respostas em tempo real, como em jogos de ação. Já a IA proporciona aos jogos recursos mais realísticos para a interação com os usuários, como a imprevisibilidade de comportamento (NAREYEK, 2001). O trabalho de Laird e van Lent (LAIRD; LENT, 2001) apresenta diversos tipos de jogos computacionais que utilizam a IA como base para diferentes atividades, como desenvolvimento de regras dinâmicas ou escolha de parceiros (para jogos coletivos). Já o trabalho de Genesereth et al. (GENESERETH; LOVE; PELL, 2005) apresenta uma nova dinâmica de desenvolvimento de jogos computacionais, totalmente baseada em 
IA, denominada General Game Playing (GGP). Esta metodologia busca desenvolver quaisquer tipos de jogos a partir de uma descrição declarativa única.

Os Jogos de Papéis (Role-Playing Games (RPGs)) estão situados entre os jogos e o teatro e consistem numa técnica onde se determinam regras e comportamentos de jogadores, bem como um contexto imaginário (ambiente). Desta maneira, RPGs são jogos onde cada jogador desempenha um papel e toma decisões, a fim de alcançar seus objetivos. Na verdade, os jogadores utilizam RPGs como um "laboratório social", isto é, como uma forma de experimentar uma variedade de possibilidades, sem sofrer as conseqüências do mundo real (BARRETEAU; PAGE; D'AQUINO, 2003).

Os RPGs surgiram 1973 nos Estados Unidos, através do Dungeons $\&$ Dragons (DESD), uma ambientação de fantasia medieval livremente inspirado na obra de Tolkien, escritor inglês do gênero fantasia, autor da famosa triologia denominada O Senhor dos Anéis. Costuma-se dizer que a escolha desta obra foi realizada por ser mais apropriada a um RPG, porém isto não é verdade. A escolha valeu-se do gosto pessoal de seus autores, Dave Arneson e Gary Gygax, e confirmada durante os jogos-teste, quando se percebeu que a fantasia medieval agradava bastante (KLIMICK, 2003). O jogo se tornou um sucesso em um curtíssimo espaço de tempo. Um exemplo isso é que em uma das primeiras cenas do filme E.T., de Steven Spielberg, apresenta um grupo de adolescentes jogando D\&D.

O RPG pode ser impresso (em mapas, fichas de personagens, etc.), eletrônico ou oral. Ele consiste em uma categoria a parte nos jogos, em função de seu aspecto de colaboração em vez de competição: os RPGs não são jogos onde têm-se um final com ganho ou perda. Ao final, deve-se completar uma história construída a partir das regras do jogo, e buscando objetivos individuais e/ou coletivos. Desta forma, um fator muito marcante dos RPGs é sua capacidade de integração, visto que é jogado em grupos, e como já dito acima voltado para a cooperação entre seus participantes. Existe um famoso ditado no meio do RPG que sintetiza esta filosofia: "grupos separados levam a mortes simultâneas"(KLIMICK, 2003). Desta maneira, os RPGs têm como foco a interação entre os indivíduos, ou seja, seus jogadores.

Baseando-se na área de GroupWare (ELLIS; GIBBS; REIN, 1993), onde a interação entre os indivíduos é fundamental, pode-se dividir os RPGs em quatro formas, dependendo do tempo e do local de realização do jogo, conforme a Tabela 2. Assim, quando o jogo é realizado ao mesmo tempo e em um mesmo local, tem-se uma interação face-a-face entre os jogadores. Quando o jogo é realizado 
ao mesmo tempo, mas em locais diferentes, tem-se uma interação distribuída síncrona. Quando o jogo é realizado em tempos diferentes, e em um mesmo local, tem-se uma interação assíncrona. E quando o jogo é realizado em tempos diferentes e em locais diferentes, tem-se uma interação distribuída assíncrona.

\begin{tabular}{|c|c|c|}
\hline \hline & Mesmo tempo & Tempo diferente \\
\hline \hline Mesmo local & interação face-a-face & interação assíncrona \\
\hline Local diferente & interação distribuída síncrona & interação distribuída assíncrona \\
\hline \hline
\end{tabular}

Tabela 2: Divisão dos RPGs a Partir do Tempo e do Local de Realização, Baseado na Área de GroupWare (ELLIS; GIBBS; REIN, 1993).

O RPG possui o potencial de, através do exercício da fantasia, agir positivamente no desenvolvimento mental do homem e, conseqüentemente, no seu desenvolvimento social. Se observado com maior cuidado, pode-se perceber a força de integração latente de auxílio pedagógico, pois o jogo estimula uma troca constante de informações e experiências. Assim, "se bem direcionado e explorado, o RPG tem tudo para ter um papel marcante na sociedade" (KLIMICK, 2003).

Diversas aplicações são possivéis a partir da técnica de RPG. Uma delas é treinamento, pois pode colocar os jogadores em situações de tomada de decisão similares às reais, porém sem conseqüências concretas. Em especial, grandes empresas utilizam RPG para treinamento de funcionários, colocando-os em situações de extrema pressão e risco, visando desenvolver seus traços de autocrítica e de senso de realidade. Outro aspecto importante é o fator lúdico envolvido nos jogos, o que faz com que o treinamento e/ou aprendizagem de determinado assunto seja realizado de forma facilitada (BARRETEAU; BOUSQUET; ATTONATY, 2001).

Alguns RPGs também fazem uso de técnicas de IA em seu desenvolvimento. Um exemplo é o Diplomacy (AGAR, 1994), um RPG muito conhecido, baseado na Primeira Guerra Mundial, onde os jogadores representam os países participantes da guerra, e devem desenvolver estratégias para tentar vencer a mesma. A utilização de IA é realizada de forma individual, onde o sistema tentar dar dicas de estratégias a cada um dos jogadores, baseado nas ações anteriores do jogador e de seus adversários.

O RPG se destaca por ter a fantasia como seu principal instrumento, sendo justamente este aspecto que o torna um jogo com múltiplas possibilidades. Para entender a importância deste fato, é preciso antes entender a importância da fantasia para o desenvolvimento da mente humana. No RPG, o jogador tem a oportunidade de viver diferentes personagens, viver em diferentes mundos, em diferentes realidades. A construção do personagem no RPG é uma fonte 
de muitas informações sobre os pacientes para qualquer psicoterapeuta, pois o jogador descarrega nele todos os seus sonhos, todas as suas frustrações, seus desejos, até mesmo quando tenta interpretar um personagem totalmente diferente de si mesmo. Tanto isso é verdade que psicólogos têm analisado RPG e suas implicações no comportamento dos jogadores, porque há uma significativa relação entre RPG e um tipo de psicoterapia chamada psicodrama (BANDINI; MANZONI; VIZZARI, 2002; DOUSE; MCMANUS, 1993). O psicodrama é um método psicoterápico centrado na interação social, também chamado de "Sociatria", ou seja, a ciência que procura explorar a verdade (do indivíduo) através de métodos dramáticos. No psicodrama, o paciente não é levado a se transformar em um ator. O paciente terá de representar a si próprio, porém terá que expor suas forças e/ou fraquezas com mais intensidade do que ele normalmente faz em seu cotidiano. Este método não é muito diferente do que ocorre no RPG, porém através de caminhos mais espontâneos.

Outro aspecto é a capacidade de integração dos RPGs, que começa na própria estrutura do jogo: é jogado em grupo, não é voltado para competição, mas sim para a cooperação entre seus participantes. Além disso, é um jogo onde o discurso, diálogo e troca de idéias são vitais para o seu desenvolvimento.

Um aspecto importante a ser lembrado é que a fantasia do RPG funciona como uma regressão tática da mente, visando uma melhor adaptação posterior à realidade. E, de fato, apesar do jogador se desligar da realidade enquanto se deixa levar pela fantasia do jogo, este exercício constante da imaginação lhe proporciona instrumentos poderosos na interação com a realidade, pois após experimentar (na fantasia) diversas realidades, diversas maneiras de ser, inúmeras situações e experiências, o jogador está munido de um rico repertório de ações, pensamentos, reações e emoções (BANDINI; MANZONI; VIZZARI, 2002).

\subsection{Sistemas de Apoio à Decisão em Grupos (SADs-G)}

Os chamados Sistemas de Apoio à Decisão (SADs) são um sub-grupo dos Sistemas de Informação, que fornecem dados para o apoio à tomada de decisão (DORNElas, 2000; FAlSARELlA; CHAVES, 2003). Para os SADs, a obtenção da informação é apenas parte do processo, focando principalmente em técnicas onde os dados são analisados e apresentados de uma forma que as pessoas consigam entender todo o sistema (WEBOPEDIA, 2006). Quando se analisa o trabalho coo- 
perativo, tem-se os chamados Sistemas de Apoio à Decisão em Grupos (SADs-G), que visam trabalhar em grupos, para ter-se um maior entendimento do problema e estimular a participação. Contudo, o trabalho cooperativo pode trazer também problemas, como a falta de coordenação no trabalho, o excesso de tempo consumido para executar uma tarefa e a influência indesejada dos processos de dinâmica dos grupos (DORNELAS, 2000; BISPO, 1998).

Algumas vezes, pode haver confusão entre sistemas de Groupware e SADsG. Contudo, sistemas de Groupware priviligiam a comunicação e coordenação e os SADs-G focam no apoio à decisão, na organização das informações e na modelagem e escolha de alternativas (DORNELAS, 2000).

Segundo Huber (HUBER, 1984), os SADs-G têm por meta facilitar a interação entre pessoas e possivelmente entre agentes autônomos independentes, sendo uma tecnologia para suportar atividades de grupos. Sua utilização geralmente incentiva a participação, reduz o tempo e aumenta a qualidade dos resultados obtidos em reuniões, especialmente quando grandes grupos estão envolvidos em tarefas complexas (COSTA et al., 2000; DORNELAS, 2000).

Um exemplo bastante interessante da utilização de SADs-G é o trabalho desenvolvido por Dornelas (DORNELAS, 2000), onde um SADs-G foi desenvolvido para processos decisórios que ocorressem em ambientes públicos participativos durante o "Orçamento Participativo", em Porto Alegre/RS. O orçamento participativo é uma forma de utilização de recursos públicos, onde as comunidades definem, a partir de reuniões, como e onde aplicar estes recursos. Porto Alegre foi a primeira cidade do Brasil a instituir este tipo de decisão coletiva sobre a aplicação do dinheiro e poucos estudos sobre os impactos deste tipo de negociação haviam sido realizados, bem como a utilização de sistemas computacionais para ajuda na tomada de decisão dos grupos participantes das reuniões do orçamento participativo. A conclusão final do autor, após a utilização de um SADs-G, foi que a inserção deste tipo de sistema computacional auxiliou os participantes em suas tomadas de decisão, agilizando o processo decisório de grupos.

A seguir, a seção 2.3.1 apresenta a utilização de SADs-G para Gestão de Recursos Naturais e a seção 2.3.2 apresenta o funcionamento da metodologia GMABS e que é utilizada para o desenvolvimento de sistemas de apoio à decisão em grupos. 


\subsubsection{Apoio à Decisão na Gestão de Recursos Naturais}

No contexto de sistemas complexos, o processo de negociação na gestão de recursos naturais é um tópico muito importante, pois envolve diferentes atores, grupos de interesse e instituições que interagem com o ecossistema (BOUSQUET et al., 1999). A quantidade e diversidade de atores neste domínio é grande, sendo que estes têm objetivos e estratégias diferentes entre si.

As preocupações ambientais, porém, começaram a aparecer no momento que a população humana global aumentou, juntamente com o seu consumo de recursos naturais (CUSTODIO, 2004). A sua exploração, freqüentemente realizada de modo competitivo e destrutivo, tornou tais recursos extremamente escassos. Segundo Doran (DORAN, 2001), isso é fruto de administrações burocráticas e centralizadas (top-down), visando lucro, que se tornaram alvos de maciças críticas. As administrações integradas, respeitando os diversos aspectos de um ecossistema, e de sustentabilidade, iniciaram-se há muito pouco tempo, e ainda não se tem clareza de qual é a melhor maneira para gerenciar estes recursos. Desta forma, se faz necessário o estudo de sistemas de apoio à decisão para lidar com este problema tão complexo.

MABS vem sendo utilizado há vários anos na gestão de recursos naturais e renováveis, pois os pesquisadores dessa área logo perceberam que a interação entre os agentes e seu ambiente era vital para realização de simulações desse tipo de fenômeno (BOUSQUET et al., 1999).

Ferramentas tradicionais para ensino e treinamento, como RPG, têm sido também usadas com sucesso em certas fases envolvendo negociação do uso de recursos naturais, como no planejamento do uso da água e do solo (D'AQUINO et al., 2003). Tais ferramentas têm-se mostrado eficientes, pois facilitam a comunicação entre cenários imaginários e o mundo real.

Os jogos dependem de um diagnóstico a priori da situação dos participantes, isto é, da verificação dos seus níveis de conhecimento, de maneira a definir graus de dificuldade para o jogo. Entretanto, tais jogos auxiliam os jogadores a compartilhar seus conhecimentos e aperfeiçoar suas técnicas. Por exemplo, se um jogo tem um propósito educativo, e tem como alvo crianças ou pessoas com conhecimento limitado, ele deve ser simples e lúdico. Caso o jogo tenha como objetivo aprimorar conhecimentos de especialistas na área (por exemplo, explicar uma nova lei para advogados), a maioria dos conceitos utilizados no jogo pode ser suprimida, pois os jogadores conhecem bem o domínio de aplicação, e o jogo pode ser mais 
complexo e direto.

Modelos baseados em agentes são ferramentas interessantes para desenvolver uma representação integrada de processos dinâmicos em fases iniciais do processo de negociação. O trabalho de modelagem é visto como um meio de estruturar tanto as representações quanto as suas alterações (evolução), o que facilita a discussão e o processo de aprendizagem. Esses modelos, muitas vezes baseados em linguagem orientadas a objetos, são também conhecidos com modelagem de sociedades virtuais. Eles são baseados na representação de agentes, considerando a tomada de decisão autônoma nas entidades do modelo.

Para Barreteau (BARRETEAU; BOUSQUET; ATTONATY, 2001), utilizar de forma integrada as técnicas de MABS e RPG é uma maneira de unir a capacidade dinâmica de MABS com a capacidade de discussão e aprendizado das técnicas de RPG. A metodologia de utilização integrada das técnicas de RPG e MABS foi proposta inicialmente em (BARRETEAU; BOUSQUET; ATTONATY, 2001), sem uma denominação particular, e será aqui denominada Games and Multi-AgentBased Simulation (GMABS).

\subsubsection{Metodologia GMABS}

A metodologia Games and Multi-Agent-Based Simulation (GMABS) utiliza as técnicas de RPG e MABS de forma integrada. Na Figura 2 são apresentados os passos necessários para esta integração.

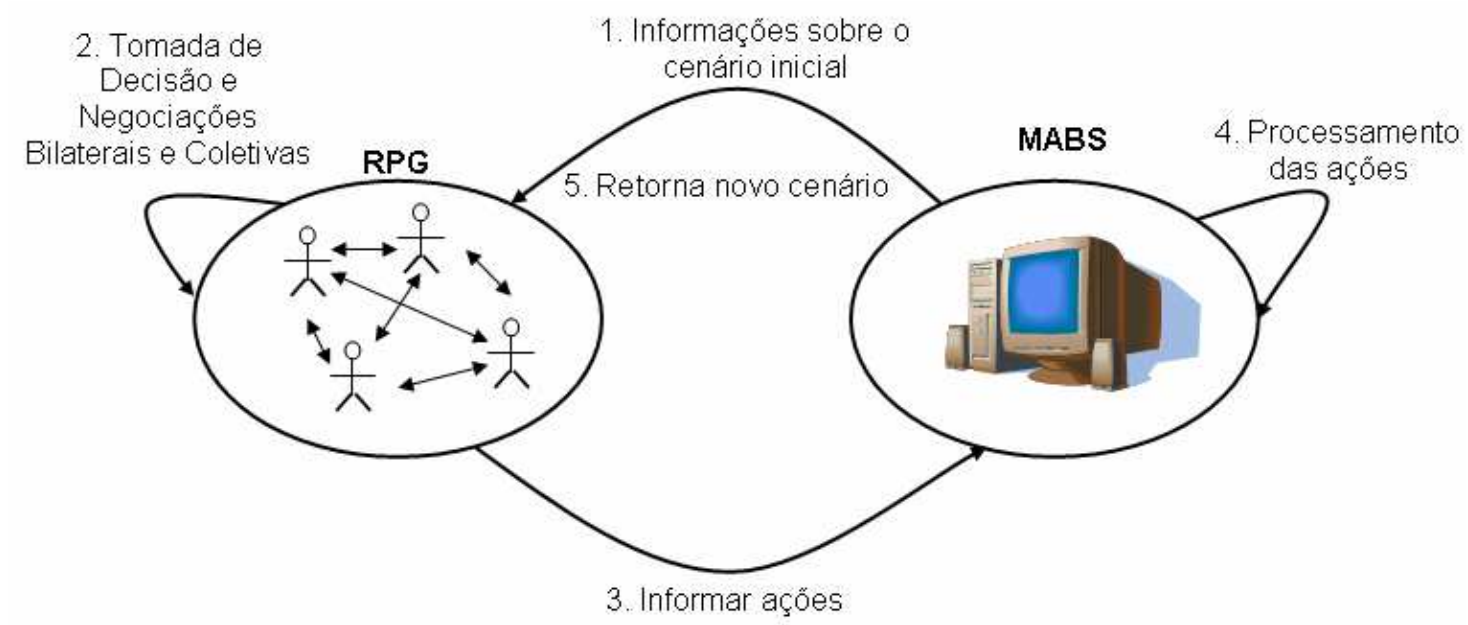

Figura 2: Funcionamento da Metodologia GMABS.

1. Os jogadores recebem todas as informações sobre o jogo (regras e cenário inicial). São definidos os papéis que cada jogador irá desempenhar. Suponhase um jogo onde existem os papéis de industrial e ecologista, e cujo objetivo 
é verificar a qualidade das águas de uma determinada região. Cada jogador primeiramente saberá quais as regras que cada papel pode executar e os possíveis benefícios e/ou prejuízos suas ações podem causar a qualidade da água, bem como onde estão fisicamente localizados no jogo e o que possuem inicialmente (dinheiro, terras, etc..). Para o caso do papel do industrial, pode ser definido qual é o tamanho, local, lucratividade, a quantidade de poluição, etc., de sua(s) empresa(s).

2. Este passo envolve três atividades:

(a) Os jogadores decidem sobre ações individuais, que dependem exclusivamente deles próprios, como a mudança de uso do solo de um de seus lotes;

(b) De posse de todas as informações necessárias, os jogadores iniciam as negociações bilaterais, como venda/compra de lotes. As negociações bilaterais envolvem sempre dois jogadores. Se a negociação bilateral for concluída, gerará uma ação para efetivar a negociação realizada. Por exemplo, dois jogadores negociam sobre a venda/compra de um lote. Se estes jogadores entrarem em acordo, uma ação será gerada para efetivar a venda do lote em negociação.

Normalmente, a duração das atividades (a) e (b), que ocorre de forma simultânea, é definida no início do jogo (por exemplo, 30 minutos). Em alguns casos, é necessário um tempo maior para estas duas atividades, dependendo da quantidade de jogadores, dificuldade das regras do jogo, etc.

(c) Após decidirem sobre ações individuais e negociações bilaterais, os jogadores também negociam estratégias coletivas que devem ser tomadas nas rodadas seguintes do jogo, de forma a beneficiar todos os jogadores, ou um grupo deles. Os jogadores podem reenvindicar melhorias em relação a infra-estrutura, empregos, valores de impostos, etc. Por exemplo, um industrial pode solicitar isenção de impostos para instalar sua empresa em um determinado município.

Este processo de negociação de estratégias coletivas para execução de futuras ações é apenas uma "conversa" para definir metas futuras. Não há formalização do cumprimento do que foi negociado, mas é importante para que cada jogador entenda melhor os objetivos e futuras estratégias dos outros jogadores; 
3. Os jogadores informam ao simulador MABS quais foram suas ações escolhidas: ações individuais (2a) e negociações bilaterais concluídas (2b);

4. Os dados são computados pelo simulador MABS (processamento das ações): estas ações irão modificar o cenário inicial. As propriedades do ambiente são modificadas, o que implica na modificação de dados de cada papel. Por exemplo, se o jogador que representa o industrial resolve instalar uma nova industria no cenário, o jogador que representa o ecologista perceberá a mudança no índice de poluição das águas. Este passo é o final do primeiro turno de jogo;

5. O simulador MABS retorna o novo cenário, após as alterações realizadas pelas ações escolhidas pelos jogadores.

Um novo turno é iniciado, retornando-se ao passo 2. Esta seqüência de passos poderá ser repetida diversas vezes, dependendo dos objetivos do jogo. Normalmente, o primeiro turno de simulação é mais longo (tempo de duração), pois os jogadores estão conhecendo melhor as regras e como manipular os recursos que o jogo oferece. Os turnos seguintes são mais curtos, pois os jogadores já têm um objetivo e definiram as estratégias para conquistá-lo. Independente do número de rodadas, ao final, sempre é realizado uma discussão sobre as escolhas feitas por cada jogador, com o objetivo de entender melhor a problemática e possíveis soluções apresentadas. Esta discussão é chamada de debriefing na literatura de jogos (DORN, 1989; LEDERMAN, 1992; PETERS; VISSERS; MEER, 1998; EGENFELDT-NIELSEN, 2004).

Os jogadores realizam as negociações no passo 2. Podem-se diferenciar dois tipos distintos de negociação:

- Negociações Bilaterais: realizadas entre dois jogadores ao mesmo tempo para uma determinada ação que será executada pelos jogadores envolvidos na negociação. Por exemplo, a compra de um lote é negociada apenas entre o interessado em comprar (comprador) e o proprietário (vendedor) e, se houver acordo entre ambas as partes, resultará na ação de compra de um determinado lote. Este processo de negociação bilateral, juntamente com a tomada de decisão individual, é chamado de Fase 1 na metodologia GMABS;

- Negociações Coletivas: realizadas por todos os jogadores ao mesmo tempo, para determinar estratégias coletivas a serem executadas em turnos futuros 
de jogo, não envolvendo a efetivação de qualquer ação por parte dos jogadores. Por exemplo, os jogadores negociam sobre a ampliação da rede de água potável. Em turnos futuros, ações relacionadas a esta estratégia podem ser executadas ou não, pois não existe obrigação por parte dos jogadores de cumprir as estratégias coletivas negociadas. Este processo de negociação coletiva é chamado de Fase 2 na metodologia GMABS.

A troca de informações realizadas entre o simulador MABS e os jogadores do RPG (passos 1, 3 e 5 da Figura 2), podem ser executados de diversas formas. Por exemplo, se os jogadores não acessarem diretamente o simulador MABS, apenas preenchem formulários em papel com as informações sobre as ações escolhidas e os repassam a um operador que interage este simulador (também chamado de processo "paper-based", pois os jogadores não interagem o computador). Esta troca de informações irá depender também da forma que o RPG será realizado (conforme apresentado na Tabela 2). Por exemplo, se a forma de realização do RPG for distribuída síncrona, e realizada via $W e b$, os jogadores terão uma interface gráfica para inserção das ações escolhidas, de forma que o simulador MABS possa lê-las e executá-las.

\subsection{Jogadores Virtuais}

Neste trabalho, utiliza-se a tecnologia de agentes para a inserção de jogadores virtuais na metodologia GMABS. Dentro das contribuições esperadas, deseja-se definir jogadores virtuais cuja tomada de decisão seja parecida a dos jogadores reais. Para os jogadores virtuais terem este tipo de tomada de decisão, eles devem ser baseados em SMAs cognitivos, conforme apresentado na seção 2.1. Em SMAs cognitivos, os agentes têm uma representação explícita de seu ambiente, de outros agentes e deles mesmos, e são baseados em modelos humanos, possuindo raciocínio e capacidade de planejamento de suas ações.

Em trabalhos na área de SMAs, utilizam-se agentes cognitivos em interfaces inteligentes que auxiliam os usuários (HOOK; SVENSSON, 1999) ou em simulações computacionais de diversas aplicações (NANDALAL; SIMONOVIC, 2003). Na área de jogos computacionais, quando são utilizados agentes, na maioria dos casos estes são reativos. Um exemplo de utilização de agentes cognitivos em jogos é o trabalho de Bianchini (BIANCHINI, 2005), que insere emoções em alguns personagens do cenário de um jogo 3D, tentando dar maior realismo aos jogadores.

Em trabalhos utilizando a metodologia GMABS, os agentes estão inseridos 
na simulação. Estes agentes são normalmente reativos e têm o objetivo de criar alguma aleatoriedade nas simulações. Um exemplo na área de gestão de recursos naturais é o trabalho de Etienne (ETIENNE, 2003), onde um agente reativo pode iniciar um incêndio em uma floresta, se um conjunto de regras for atendido.

Para definir jogadores virtuais utilizando agentes, faz-se necessário estudar como será realizada a tomada de decisão destes jogadores, a partir das arquiteturas cognitivas definidas para agentes. Na seção 2.4.1 são apresentadas algumas arquiteturas definidas dentro deste contexto.

Além do estudo do modelo de tomada de decisão, os jogadores virtuais também terão a capacidade de comunicar-se entre si e com os jogadores reais, sendo necessário também definir um protocolo de negociação para os jogadores, que é apresentado na seção 2.4.2.

\subsubsection{Arquiteturas Cognitivas para Agentes}

Uma arquitetura de agentes refere-se à forma como é realizada a organização interna de cada agente e como estão estruturados seus relacionamentos e interações. Segundo Maes (MAES, 1991):

".... é uma metodologia particular para a construção de agentes. Ela especifica como o agente pode ser decomposto na construção de um conjunto de módulos componentes e como esses módulos devem ser feitos para interagir. O conjunto total de módulos e suas interações têm que fornecer uma resposta à questão de como o sensor de dados e o estado interno atual do agente determinam suas ações. Uma arquitetura abrange técnicas e algoritmos que suportam essa metodologia....".

Desta maneira, a arquitetura de um agente especifica a sua estrutura e o seu funcionamento. As arquiteturas de agentes podem ser classificadas a partir de diversos parâmetros, como a aplicação ou grau de sofisticação dos agentes. A ênfase neste trabalho são as arquiteturas de agentes para modelos cognitivos, ou seja, modelos de raciocínio humano. Dentro deste contexto, diversas arquiteturas foram desenvolvidas, e a seguir serão apresentadas resumidamente quatro delas: ACT-R (ANDERSON, 1996), SOAR (LAIRD; NEWELL; ROSENBLOOM, 1987), COGNET (RYDER et al., 1998) e BDI (RAO; GEORGEFF, 1995). 


\subsubsection{Arquitetura ACT-R}

A arquitetura Adaptive Character of Thought (ACT-R) está baseada em uma teoria sobre a cognição humana (ANDERSON; LEBIERE, 1998; ANDERSON; SCHUNN, 2000). A cognição é tratada pela interação entre o conhecimento procedural e declarativo.

O conhecimento procedural, como resolução de problemas matemáticos, é representado por um grande número de regras de produção, que são unidades de pares condição-ação, onde as condições significam várias condições de resolução de problemas, e as ações significam as ações cognitivas específicas para cada condição (ANDERSON; MATESSA, 1998).

O conhecimento declarativo é representado por uma rede de pequenas unidades chamadas chunks. Por exemplo, a Figura 3 mostra graficamente como um chunk codifica uma adição simples $(3+4=7)$. Um chunk realiza a união de um número de elementos (no caso, três, quatro e sete), a partir de uma configuração. Cada elemento possui um "papel", dentro de uma configuração. No exemplo da Figura 3, os papéis são Entrada1, Entrada2 e Soma, significando os termos da soma e a realização da soma em si.

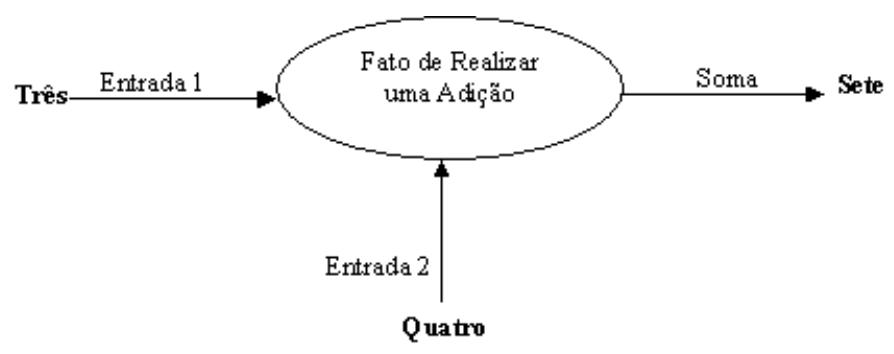

Figura 3: Representação do Conhecimento Declarativo (Chunks) em ACT-R (ANDERSON; MATESSA, 1998).

O modelo conceitual da arquitetura ACT-R é apresentado na Figura 4, onde o elemento Ambiente repassa as percepções do ambiente para o elemento Módulo de Percepção. Este elemento irá se comunicar com os elementos de Conhecimento Declarativo e/ou Conhecimento Procedural para determinar como será executada uma determinada ação, relativa a percepção repassada pelo ambiente.

\subsubsection{Arquitetura SOAR}

SOAR (LAIRD; NEWELL; ROSENBLOOM, 1987) é uma arquitetura para cognição humana genérica que visa o desenvolvimento de sistemas que necessitam de um comportamento inteligente (LAIRD, 2003). Esta arquitetura esta baseada no mo- 


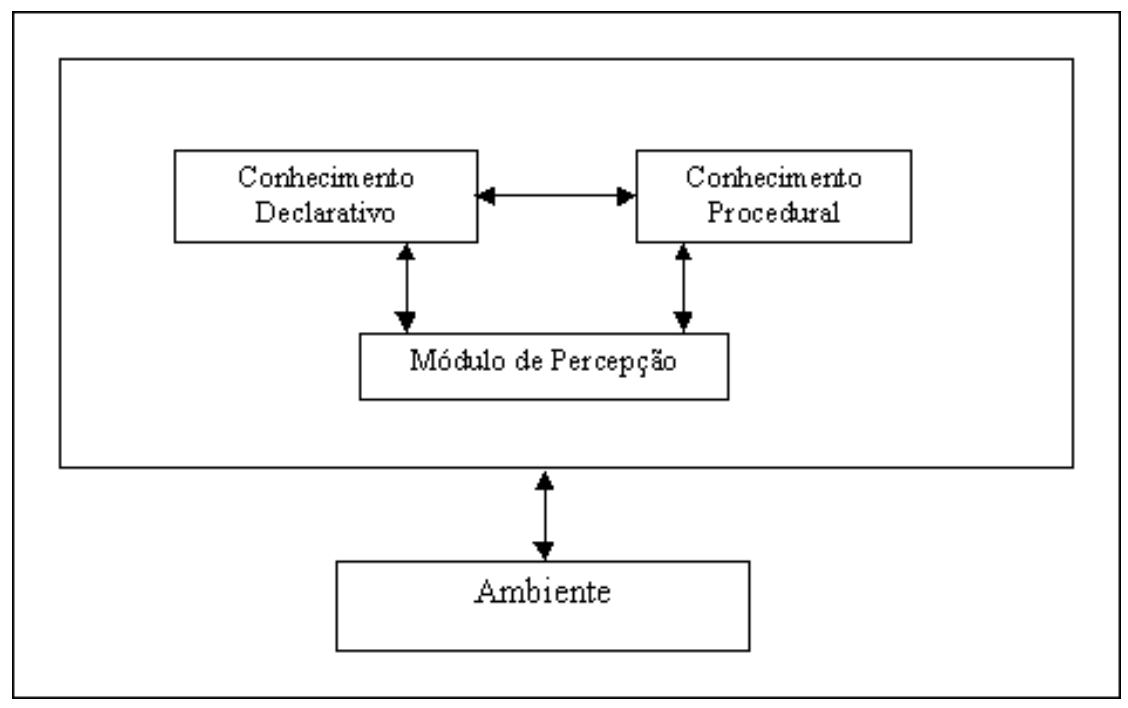

Figura 4: Modelo Conceitual da Arquitetura ACT-R, adaptada de (ANDERSON et al., 1995).

delo teórico General Problem Solver (GPS) (NEWELL; SIMON, 1972), que tem por base uma teoria de resolução de problemas humanos na forma de programas de simulação. No GPS, o passo mais importante é a definição do espaço de problemas, em termos do objetivo a ser alcançado e como transformar as regras existentes. Para solucionar isso, a idéia foi dividir o objetivo em subobjetivos e tentar resolver cada um destes separadamente. A arquitetura SOAR adotou a idéia do espaço de problemas e suas subdivisões, empregado no modelo GPS. Desta maneira, todas ações cognitivas podem ser subdivididas. A Figura 5 apresenta como é estruturada a divisão de objetivos e sub-objetivos na arquitetura SOAR. Em cinza estão os objetivos mais específicos, que serão executados primeiro.

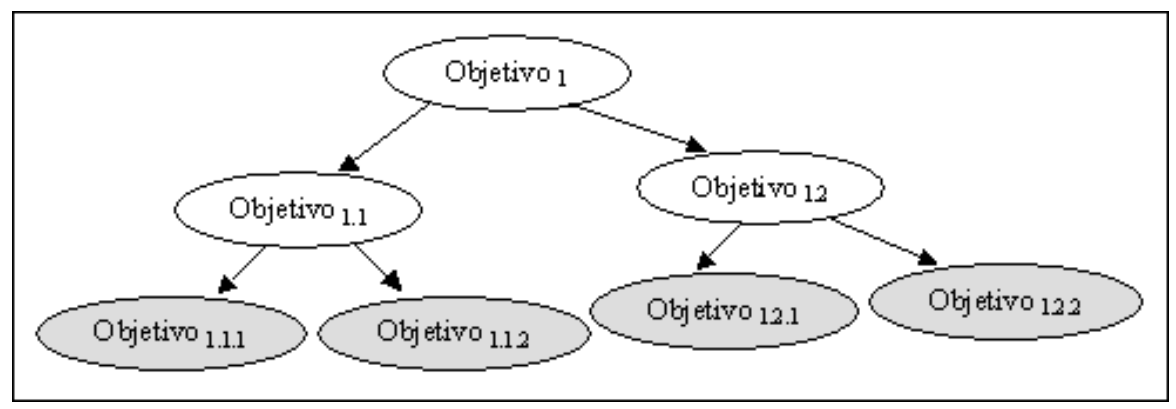

Figura 5: Estrutura de Divisão de Objetivos na Arquitetura SOAR (LAIRD, 2003).

O desenvolvimento de SOAR está baseado na hipótese que todo o comportamento deliberativo está orientado a um objetivo que pode ser alcançado através da seleção e da aplicação de operadores para um estado. Um estado é uma representação de uma solução para resolver o problema proposto; um operador transforma um estado, mudando a sua representação; um objetivo é um resultado 
desejado para um problema (LAIRD; CONGDON, 2004).

SOAR possui dois tipos de memória, uma para descrição das situações correntes (memória de curto prazo) e outra para o conhecimento de longo prazo (memória de longo prazo). Como situações correntes estão incluídos os dados para sensores, resultados de inferências intermediárias e objetivos e operadores ativos. Estas informações são tratadas como objetos, podendo ser subdividos em sub-objetos, de modo a gerar uma organização hierárquica (seguindo a idéia de subdivisão de objetivos, conforme Figura 5, onde a estrutura em árvore representa a ordem de execução dos objetivos).

O conhecimento de longo prazo sempre é acessado para resolver as situações correntes, pois possui informações sobre como selecionar e aplicar os operadores para transformar os estados e definição de como os objetivos estão armazenados. Apenas os objetivos e operadores ativos estão na memória de curto prazo, todas as outras informações estão na memória de longo prazo (LAIRD; CONGDON, 2004).

\subsubsection{Arquitetura COGNET}

A arquitetura COGnition as a NEtwork of Tasks (COGNET) foi desenvolvida para modelar a cognição humana e a tomada de decisão. Esta arquitetura promove a representação integrada de conhecimento (modelo mental), procedimentos (ações comportamentais), resolução de problemas e estratégias (operações cognitivas), que são utilizados em um determinado domínio (RYDER; ZACHARY, 1991; RYDER et al., 1998).

A arquitetura COGNET está baseada na pesquisa da ciência cognitiva, particularmente na computação simbólica, onde os processos cognitivos são representados como operações computacionais a partir de um conjunto de símbolos, também baseada no modelo teórico GPS (NEWELL; SIMON, 1972). Esta arquitetura processa a informação humana através dos mecanismos de percepção, cognição e atividade motora, e ainda trabalha com memória, onde os dados ficam armazenados para que os mecanismos de percepção e cognição possam utilizá-los. A Figura 6 apresenta o modelo conceitual da arquitetura COGNET.

O mecanismo de Percepção (inclui os processos físicos de Sensação) recebe informações do mundo externo e armazena internamente como informação simbólica ou semântica no mecanismo de memória. Estas informações são acessadas e compartilhadas pelos mecanismos de percepção e de cognição (ZACHARY; RYDER; HICINBOTHOM, 1998). A transformação interna (simbólica ou semântica), gera o "modelo mental", a partir de processos cognitivos de indução e dedução. Este 


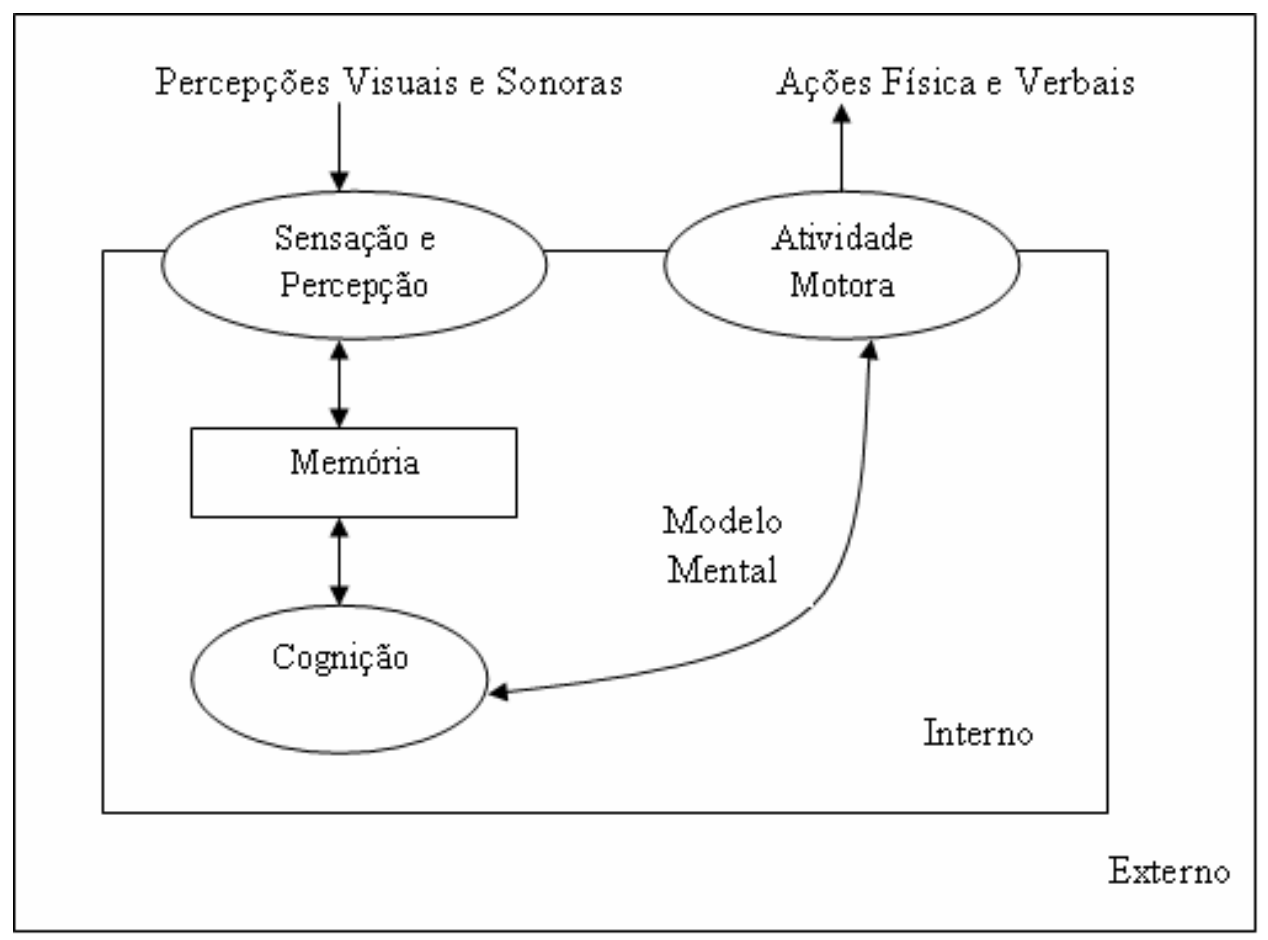

Figura 6: Modelo Conceitual da Arquitetura COGNET (ZACHARY; RYDER; HICINBOTHOM, 1998).

modelo mental repassa comandos ou instruções para o sistema motor (mecanismo de atividade motora). O mecanismo de atividade motora manipula de forma física as instruções no ambiente externo.

\subsubsection{Arquitetura BDI}

A arquitetura Belief-Desire-Intention (BDI) (RAO; GEORGEFF, 1995) é baseada nos conceitos filosóficos de intenções, planos e raciocínio prático desenvolvidos por Bratman (BRATMAN, 1987). Esta arquitetura tem suas raízes na filosofia tradicional do raciocínio prático, onde o processo de decidir ocorre momento a momento, buscando qual a ação tomar de acordo com os objetivos que se deseja alcançar. As crenças de um agente são suas visões do mundo, que não correspondem necessariamente aos estados reais do mundo, porque seus sensores podem ser imperfeitos (as informações obtidas podem ser incompletas ou incorretas). Os desejos do agente se referem a seus objetivos. Estes objetivos indicam o estado do mundo no qual o agente deseja estar, ou seja, o que os agentes gostariam que acontecesse. As intenções são as ações que os agentes executam. Ainda existe a idéia de planos, que correspondem ao "passo-a-passo" a ser seguido, a partir de uma intenção, para tomada de decisão do agente. A Figura 7 apresenta como deve ser a estrutura da arquitetura BDI para um agente.

Analisando de forma prática, de forma a ser implementado, pode-se destacar 


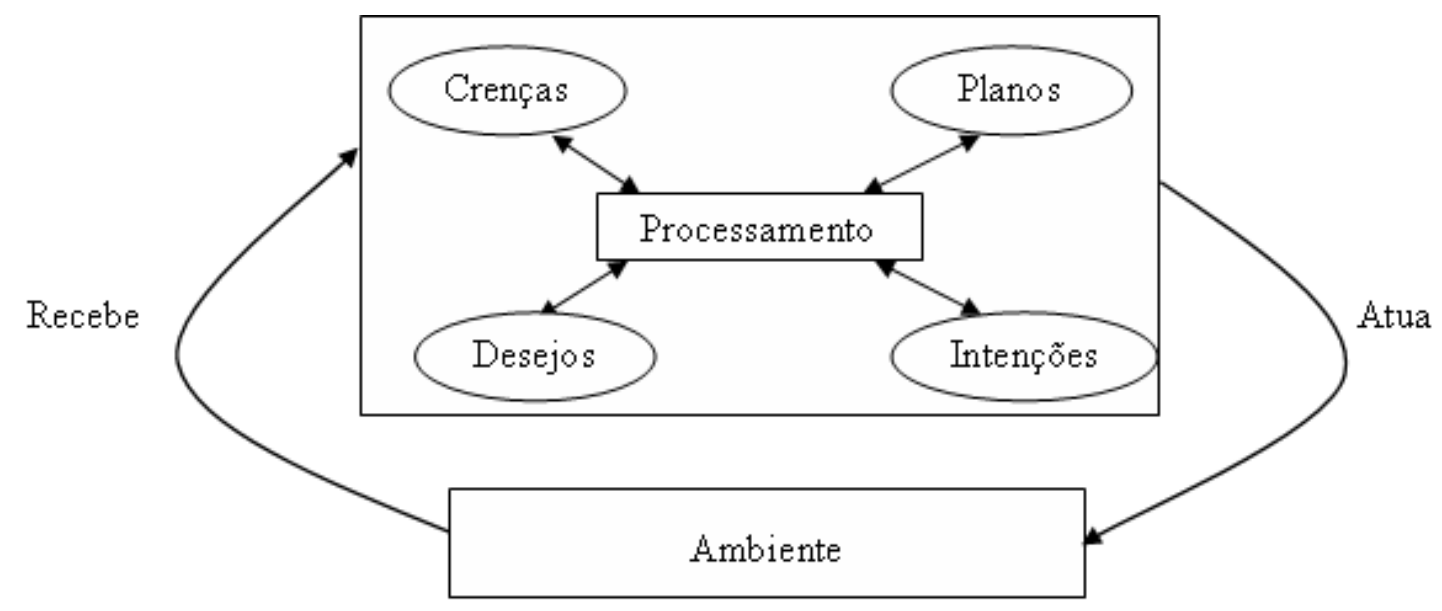

Figura 7: Estrutura da Arquitetura BDI (NORLING; SONENBERG; RONNQUIST, 2000).

os três conceitos fundamentais da arquitetura da seguinte maneira (RAO; GEORGEFF, 1995):

- Crenças: contêm a visão fundamental do agente em relação ao seu ambiente;

- Desejos: são metas dos agentes, que nem sempre podem ser postos em prática. Podem existir desejos conflituosos ou contraditórios em relação as crenças;

- Intenções: baseando nas crenças existentes, contêm o julgamento dos agentes com relação a situações futuras. Se um agente decide seguir um objetivo específico, então este objetivo torna-se uma intenção. As intenções podem ser definidas em vários níveis de abstração, sendo similares a um plano hierárquico.

Segundo Rao e Georgeff (RAO; GEORGEFF, 1995), algumas das vantagens da utilização da arquitetura BDI são:

- a representação das crenças, desejos e interações é explícita;

- os agentes são vistos a partir de um alto nível de abstração, o que facilita o entendimento de suas funcionalidades;

- atualização dinâmica da base de dados, de acordo com as alterações realizadas no ambiente (mundo) e objetivos do agente.

\subsubsection{Análise Comparativa}

As quatro arquiteturas para agentes cognitivos apresentadas, ACT-R, SOAR, COGNET e BDI, tentam codificar de alguma forma o funcionamento da cognição 
humana.

A arquitetura ACT-R trabalha com a interação entre o conhecimento procedural, que são regras do tipo "Se-então" para encontrar a ação cognitiva para uma determinada condição, e o conhecimento declarativo, que são declarações padrão de acordo com uma configuração (no exemplo apresentado pela Figura 3, a configuração declarada era para a realização de uma soma).

As arquiteturas SOAR e COGNET estão baseadas no modelo teórico GPS (NEWELL; SIMON, 1972), onde os comportamentos cognitivos são representados como operações computacionais a partir de um conjunto de símbolos. Porém, a grande diferença entre as duas arquiteturas está na forma de estruturação do espaço de problemas, pois a arquitetura SOAR divide os objetivos em subobjetivos e a memória em memória de curto e de longo prazo, e na arquitetura COGNET o espaço de problemas não é subdividido no modelo mental criado e a memória é tratada como um bloco único.

A arquitetura BDI está baseada no raciocínio prático, onde as ações são escolhidas a partir dos objetivos que se deseja alcançar. Porém, as crenças que cada agente possui sobre o ambiente e sobre os outros agentes influenciam na tomada de decisão.

Independente de como as informações são estruturadas e processadas por cada uma destas arquiteturas, pode-se dizer que todas buscam informações sobre o ambiente e sobre os outros agentes, armazenam e tratam estas informações e, ao final, escolhem as ações a serem tomadas. Por exemplo, o elemento Percepções Visuais e Sonoras (Figura 6) na arquitetura COGNET tem a mesma função que o elemento Ambiente das arquiteturas ACT-R (Figura 4) e BDI (Figura 7), que é a obtenção de informações sobre o ambiente.

Para este trabalho, escolheu-se utilizar a arquitetura BDI para tomada de decisão dos jogadores virtuais, porque esta arquitetura possui uma lógica definida, a partir da linguagem AgentSpeak(L) (RAO, 1996) e um interpretador chamado Jason (BORDINI; HUBNER, 2004). Além disso, a arquitetura BDI é a mais conhecida pelo grupo de trabalho do Laboratório de Técnicas Inteligentes (LTI), dentre as arquiteturas analisadas. Tanto que o interpretador Jason foi definido e implementado por um dos integrantes do grupo, o que reduz o risco do projeto. Maiores detalhes podem ser encontrados na seção 8.3. 


\subsubsection{Protocolos de Negociação}

Segundo (FONSECA, 2000), a palavra negociação pode ser utilizada com diferentes significados. Entretanto, quando se fala de negociação computacional, refere-se normalmente ao processo pelo qual um grupo de agentes independentes, com interesses potencialmente antagônicos, busca um acordo comum. Este acordo pode ser acerca do preço de um produto, de um local de encontro, de uma data para uma reunião, das condições de execução de uma tarefa ou de qualquer objetivo a atingir em comum. O processo de pesquisa da solução a ser adotado pode envolver a troca de informação, o relaxamento dos objetivos inicialmente traçados, concessões múltiplas ou unilaterais, mentiras, etc.

Um protocolo de negociação especifica as "regras do jogo" entre os diversos participantes na negociação, ou seja, quais as ações válidas no âmbito de cada processo de negociação. Em cada protocolo, cada um dos participantes (se racionais) utiliza a estratégia que lhe permite otimizar, do seu ponto de vista, os resultados obtidos.

\subsubsection{Critérios de Avaliação}

Dado que diferentes protocolos de negociação proporcionam diferentes resultados aos agentes neles participantes, torna-se necessário estabelecer critérios de avaliação que permitam caracterizar, sob diferentes aspectos, cada protocolo. Segundo (SANDHOLM, 1996), pode-se avaliar um protocolo de negociação a partir dos resultados obtidos pelos participantes da negociação. Desta maneira, este autor definiu alguns critérios de avaliação de protocolos de negociação:

- Justiça social: é a soma das utilidades de todos os agentes envolvidos numa dada solução. Constitui portanto uma medida global do benefício obtido por todos os agentes. No entanto, a sua avaliação é por vezes difícil pois implica a soma de utilidades de diversos agentes que podem ter naturezas completamente diferentes.

- Eficiência de Pareto: uma solução que respeita o critério de eficiência de Pareto (dizendo-se então ser ótima segundo Pareto), onde não exista nenhuma outra solução em que pelo menos um agente obtenha uma maior utilidade sem que nenhum outro perca utilidade.

- Racionalidade individual: a participação de um agente numa negociação diz-se individualmente racional se a utilidade obtida como resultado dessa 
participação é garantidamente maior ou pelo menos igual à que ele obteria se permanecesse isolado. Um mecanismo de negociação diz-se individualmente racional se for individualmente racional para todos os agentes participantes.

- Estabilidade: nenhum agente deverá receber incentivos a utilizar uma estratégia alternativa à combinada. Uma estratégia diz-se dominante para um agente se for a melhor para esse agente independentemente das estratégias utilizadas pelos outros. Muitas vezes não existe uma estratégia dominante, sendo que a melhor estratégia para um dado agente depende das estratégias seguidas pelos outros. Nestes casos, um outro critério de estabilidade é o equilíbrio de Nash: um dado conjunto de estratégias para um grupo de agentes está em um equilíbrio de Nash se cada uma delas for a melhor para cada um dos agentes no pressuposto de que os restantes agentes respeitam as restantes estratégias. Em outras palavras, num equilíbrio de Nash, cada agente escolhe a estratégia que lhe garante a melhor resposta em função das estratégias adotadas pelos restantes agentes. Nem sempre é possível obter um equilíbrio de Nash sendo, por vezes, possível obter mais do que uma solução de equilíbrio. Por outro lado há também a possibilidade de coligações entre os vários agentes que pode levar a que diferentes estratégias se tornem mais vantajosas para diferentes grupos de agentes.

- Simplicidade: o protocolo de negociação não deverá exigir demais dos agentes tanto em termos de necessidades de computação como de comunicação.

- Distribuição: o protocolo não deverá exigir a existência de um elemento centralizador do qual dependa o processo de negociação. Esse elemento poderá sempre constituir uma limitação do ponto de vista do desempenho global, podendo vir a comprometer todo o sistema em caso de falha.

- Simetria: todos os agentes devem ser tratados em pé de igualdade, não devendo ser dada vantagem a priori a nenhum deles.

Um dos primeiros protocolos de negociação para ambientes computacionais é o Contract Net Protocol (CNP) (SMITH; DAVIS, 1978), que visava autonomia de escolha por parte tanto de contratantes quanto de contratados. Embora o CNP seja bastante simples, ele assumiu uma importância extraordinária no desenvolvimento dos algoritmos de negociação automática por ter sido pioneiro neste domínio. Ele está baseado em três fases:

- anúncio: um agente anuncia a outros agentes sub-problemas que precisa resolver; 
- ofertas: os potenciais "fornecedores" avaliam o pedido e retornam ao anunciante suas propostas;

- contrato: depois de receber todas as propostas ou após um tempo limite, o anunciante seleciona a melhor proposta e estabelece contrato com o agente que fez a oferta.

\subsubsection{Teoria de Negociação de Raiffa}

Neste trabalho, o protocolo de negociação escolhido para ser utilizado na Fase 1 de negociação foi o baseado na Teoria da Negociação de Raiffa (RAIFFA, 1982). Esta teoria se enquadra em protocolos de negociação chamados de "contingentes", ou seja, que prevêem a possibilidade de rescisão quando as condições estabelecidas não forem atendidas. Em algumas situações, este tipo de contrato garante, tanto ao contratante quanto ao contratado, utilidade superior ao obtido com contratos invioláveis, onde não há possibilidade de rescisão. Foi escolhida esta teoria pois segue os critérios de racionalidade individual, estabilidade, simplicidade, distribuição e simetria anteriormente citados para avaliação de protocolos de negociação.

Desta forma, a teoria proposta por Raiffa (RAIFFA, 1982) trabalha em três âmbitos:

- Relação 2:1 = duas partes negociando e um objeto de negociação;

- Relação 2:n = duas partes negociando e n objetos de negociação;

- Relação n:n = n partes negociando e n objetos de negociação.

A primeira relação (2:1) é a mais simples e é a estudada neste trabalho, pois sempre que houver algum tipo de negociação bilateral na Fase 1, esta acontecerá entre 2 jogadores e com apenas um objeto de negociação por vez.

A Figura 8 apresenta os intervalos de negociação apresentados pelos jogadores A e B (valores mínimos: $A_{M I}$ e $B_{M I}$ e valores máximos: $A_{M A}$ e $B_{M A}$ ). É apresentado um Intervalo Comum entre os valores apresentados. Sem este intervalo, a negociação não iniciará, pois não existem interesses em comum entre os jogadores.

O jogador A inicia o processo de negociação pelo valor mínimo $A_{M I}$, e o jogador $\mathrm{B}$ com o valor máximo $B_{M A}$. Com o intuito de alcançar o Intervalo Comum entre os jogadores, o jogador A irá aumentar suas ofertas consecutivamente e o jogador B irá reduzir as suas ofertas. Assim, em um dado momento, ambos 


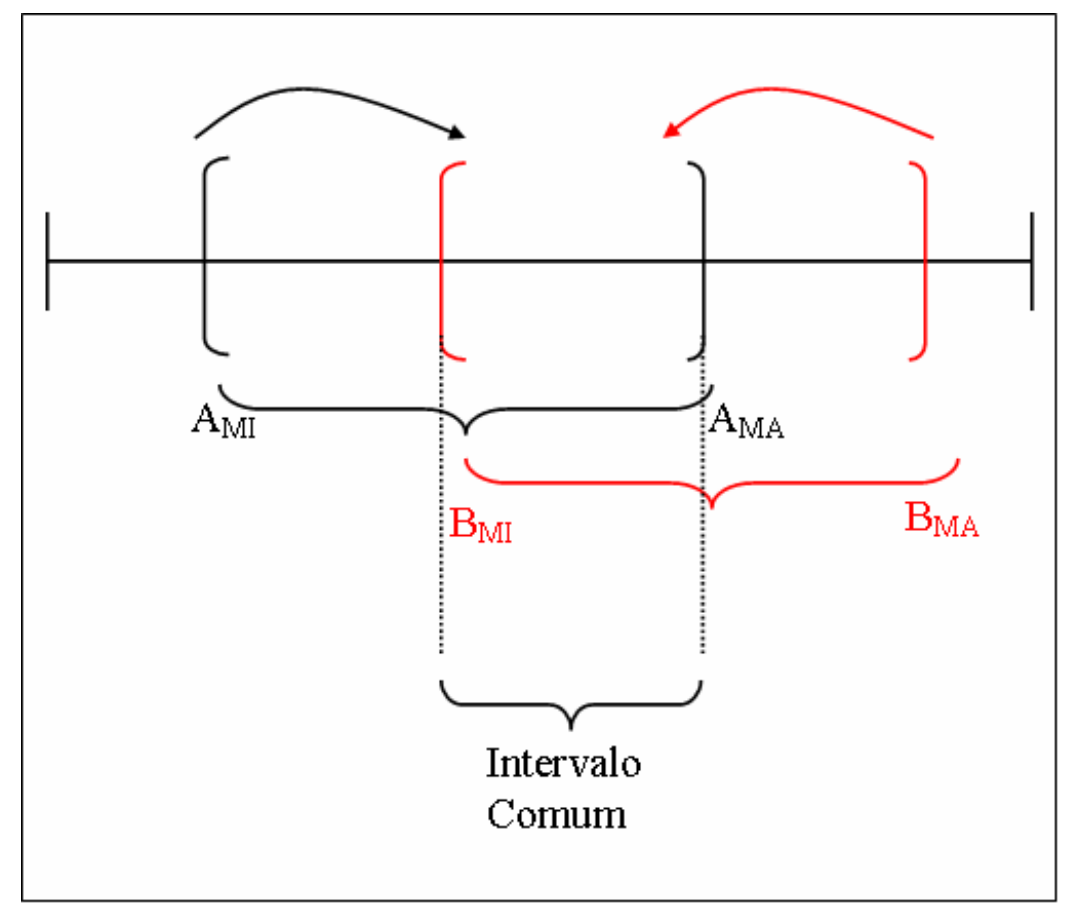

Figura 8: Teoria de Negociação 2:1 (RAIFFA, 1982).

os jogadores se encontrarão no intervalo e poderão definir um valor final para a negociação. O valor final ótimo é $\left(B_{M I}+A_{M A}\right) / 2$, ou seja, a média do intervalo existente. Porém, dependendo das regras de negociação existentes, pode-se não alcançar o valor ótimo, e sim algum dos valores do intervalo $\left[B_{M I} ; A_{M A}\right]$.

É importante ressaltar que nesta teoria de negociação o jogador A não sabe qual é o valor mínimo de $\mathrm{B}\left(B_{M I}\right)$, nem o jogador $\mathrm{B}$ sabe o valor máximo de $\mathrm{A}\left(A_{M A}\right)$. Assim, apesar de saberem que existe interesse em comum, os jogadores não sabem quando entram no intervalo comum de negociações. Em negociações reais, os jogadores realizam negociações, independente de existir ou não um intervalo comum para negociação. Quando o intervalo não existir, nunca haverá um valor final na negociação. Contudo, a existência do intervalo não implica que sempre haverá valor final em uma negociação, pois os jogadores podem, eventualmente, discordar e não concluir a negociação. A teoria não permite retrocessos, ou seja, o jogador A não pode reduzir suas ofertas, nem o jogador B pode aumentar as suas. Porém, ambas as partes podem desistir do processo a qualquer momento, independente de ter chegado ao intervalo de negociação ou não. Segundo Raiffa (RAIFFA, 1982), todo esse processo é chamado de "Dança da Negociação".

Maiores detalhes da utilização da utilização da Teoria de Negociação de Raiffa neste trabalho são apresentados na seção 8.3. 


\subsection{Considerações Finais}

Este capítulo apresentou aspectos gerais das três grandes áreas de conhecimento envolvidas neste trabalho: MABS, RPG e SAD-G. Também foram apresentadas as bases teóricas para definição dos jogadores virtuais.

O entendimento da metodologia GMABS é muito importante, pois é base para a arquitetura proposta, bem como para a implementação dos estudos de caso. Já o estudo das arquiteturas de agentes cognitivos e de protocolos de negociação entre os jogadores é necessário para definir a tomada de decisão e comunicação dos jogadores virtuais. Como já dito anteriormente, neste trabalho optou-se em utilizar a arquitetura BDI para modelar e implementar os jogadores virtuais. $\mathrm{Na}$ arquitetura ViP-GMABS, os jogadores reais e virtuais utilizarão uma versão do protocolo de Raiffa para efetuar as negociações necessárias.

No capítulo a seguir, alguns exemplos de uso de técnicas de MABS e RPG no contexto da gestão de recursos naturais são apresentados. 


\section{Uso de MABS e RPG em Gestão de Recursos Naturais}

Na literatura existem alguns exemplos de aplicação de MABS e RPG para gestão de recursos naturais, em diversas áreas, tais como recursos hídricos, problemas agrícolas, entre outros. As quatro formas de aplicação destas duas técnicas são:

1. apenas RPG;

2. apenas MABS;

3. apenas RPG e separadamente, para entendimento do jogo e/ou como ferramenta de apoio, a utilização de MABS;

4. utilização da metodologia GMABS.

Para cada uma dessas formas de utilização de 1 a 4, será respectivamente apresentado um exemplo, nas seções 3.1, 3.2, 3.3 e 3.4. Também serão verificados, ao final de cada exemplo, cinco aspectos: técnicas utilizadas, necessidade de operador para inserir os dados no simulador MABS, objetivos, público-alvo e forma de avaliação. Uma comparação destas formas de uso será então mostrada na seção 3.5. Finalmente, a seção 3.6 apresenta as considerações finais deste capítulo.

\subsection{Desafio das Águas}

O Desafio das Águas é um RPG voltado a um projeto de educação ambiental na região metropolitana de São Paulo. Foi desenvolvido por uma organização não-governamental, o Instituto Ecoar para a Cidadania. Neste jogo, todos os jogadores têm como objetivo chegar a um acordo sobre uma polêmica apresentada, com o intuito de estimular a participação e a ação coletiva nas decisões, 
vivenciando momentos de negociação e cooperação. O jogo é realizado de forma não computacional, utilizando mapas, fichas, etc. (JUNQUEIRA; MATTOS, 2004).

Neste projeto, a Educação Ambiental é vista como uma necessidade na vida e no cotidiano dos indivíduos. Ela é uma filosofia de vida que resgata valores éticos, estéticos, democráticos e humanistas. Seu objetivo é assegurar uma maneira de viver mais coerente como os ideais de uma sociedade sustentável e democrática.

O projeto teve por objetivo capacitar e qualificar a sociedade civil para participação em órgãos colegiados, instrumentalizando-a para a tomada de decisões e fortalecendo sua capacidade de intervenção em questões ligadas à gestão de recursos hídricos, e também estimular e apoiar a formação de redes de comunicação voltadas à proteção, recuperação e melhoria do meio ambiente e qualidade de vida das populações que vivem em centros urbanos, próximos às áreas de mananciais.

O Desafio das Águas é uma simulação de fatos do cotidiano, onde cada jogador interpreta um personagem, tendo todos como objetivo chegar a um acordo em relação à polêmica apresentada, estimulando a participação e ação coletiva nas decisões, vivenciando momentos de negociação e cooperação. Por exemplo, três jogadores representam os papéis de moradores de um bairro, e a estes é apresentada uma matéria de jornal, onde mudanças relativas a coleta de esgoto do seu bairro serão realizadas pela prefeitura. Esta ação é a situação polêmica apresentada aos jogadores, que devem discutir e sugerir possíveis soluções para a problemática.

Resumidamente, o Desafio das Águas apresenta os seguintes aspectos:

- Técnicas Utilizadas: apenas RPG;

- Operador: não existe operador;

- Objetivos: estimular participação e ação coletiva nas decisões de uso público;

- Público-alvo: qualquer âmbito da sociedade;

- Avaliação: não existe um processo de avaliação explícito.

\subsection{SHADOC}

O SHADOC (Hydro-agricultural describing organization and coordination models) é um modelo baseado em MABS para descrever o sistema de irrigação do Vale do Rio Senegal, no Senegal (BARRETEAU et al., 2004). O modelo está baseado 
na idéia de que o sistema de irrigação é um lugar para aquisição e alocação de água e que existem formas de acesso ao crédito para investimento em irrigação.

As regras desenvolvidas para os agentes foram estruturadas a partir do acesso e partição do crédito para irrigação e em como utilizar a água da melhor forma possível.

As simulações permitem observar a longevidade dos sistemas de irrigação e assim, constituir regras de intervenção para melhor utilização. Os cenários implementados foram divididos em três grupos: as regras coletivas, os comportamentos individuais das populações e os parâmetros de estrutura e de ambiente (por exemplo, tamanho do perímetro ou taxa de infiltração). Estes cenários foram utilizados para criar algumas teorias para sistemas de irrigação. Segundo (BARRETEAU et al., 2004), é possível demonstrar a correlação entre algumas regras com seus efeitos sobre a viabilidade dos cenários. Por exemplo, algumas regras de comportamento individual têm efeito sobre o todo (coletivo) e podem viabilizar alguns cenários que anteriormente poderiam ser considerados inviáveis.

A partir das simulações realizadas, foi possível entender melhor a complexidade de sistemas de irrigação, bem como, a relação existente entre as variáveis e regras existentes. As simulações podem ser vistas como ferramenta de apoio, pelos cenários implementados. A Figura 9 apresenta alguns resultados da simulação, para a estação de bombeamento (relacionada a aquisição e alocação de água) e para o banco (relacionado ao acesso ao crédito para investimento em sistemas de irrigação), após iniciada a estação de plantação. Pode-se verificar que a estação de bombeamento não tinha mais água após alguns ciclos de simulação, porém os valores existentes no banco não foram muito alterados. Como esses dados se referem ao início da estação de plantação, todos os investimentos em sistemas de irrigação já foram realizados, porém a água necessária para irrigação está sendo utilizada em grande quantidade neste período.

O SHADOC apresenta os seguintes aspectos:

- Técnicas Utilizadas: apenas MABS;

- Operador: existe um operador que executa e apresenta os dados das simulações realizadas;

- Objetivos: descrever o sistema de irrigação do Vale do Rio Senegal (Senegal);

- Público-alvo: agricultores da região do Vale do Rio Senegal; 


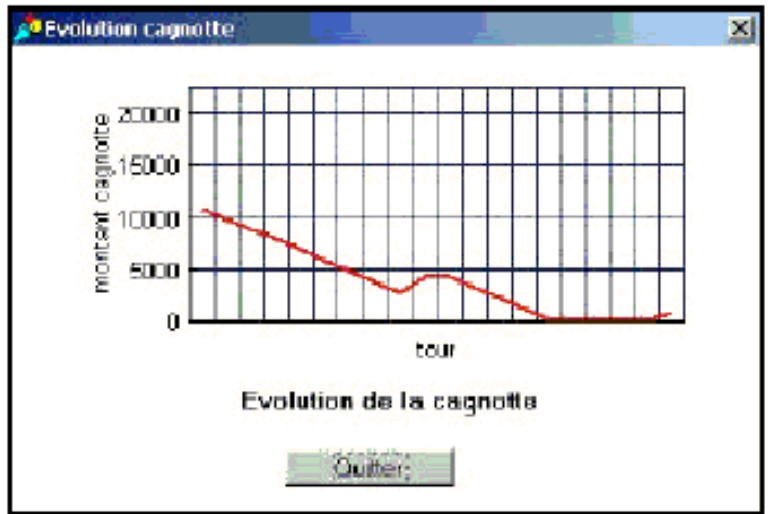

pumping station

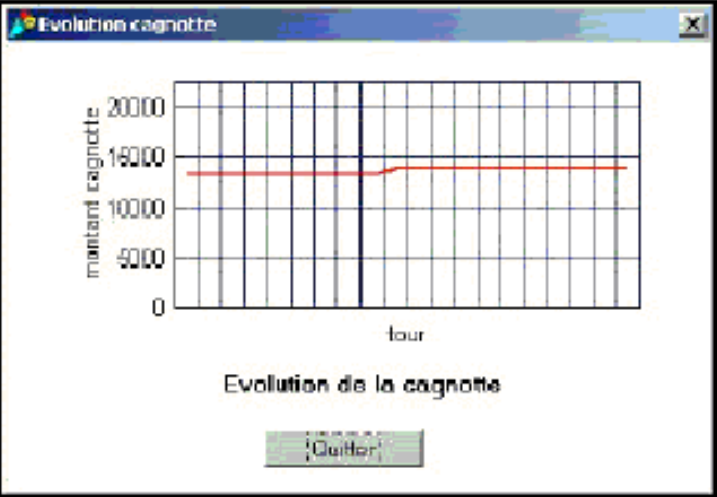

bank

Figura 9: Resultados da Simulação para a Estação de Bombeamento de Água e para o Banco (BARRETEAU et al., 2004).

- Avaliação: não existe um processo de avaliação explícito.

\subsection{SAMBA-Week}

SAMBA-Week é uma metodologia que visa habilitar o diálogo entre os atores em diversas situações locais no âmbito da agricultura (BOISSAU; CASTELLA, 2003). Sua aplicação se realizou em áreas rurais do norte do Vietnã. Seus principais objetivos foram:

- Coletar informações quantitativas e qualitativas sobre os agentes envolvidos no processo de participação nas decisões locais;

- Estudar a emergência de instituições sobre as ações individuais;

- Promover agricultura sustentável através do desenvolvimento de uma plataforma de comunicação, a partir de novas formas.

Esta metodologia esta subdivida em quatro etapas, indicadas na Figura 10:

- Informações Preliminares e Seleção dos Participantes: devem ser selecionados participantes que representem um grupo da sociedade.

- Simulação-Jogo: é realizado um RPG não computacional, onde cada participante deve tomar as decisões sobre uso e ocupação do solo de uma região fictícia.

- Entrevistas Individuais: na primeira fase das entrevistas, cada participante é questionado sobre as ações tomadas na etapa anterior. Na segunda fase os 


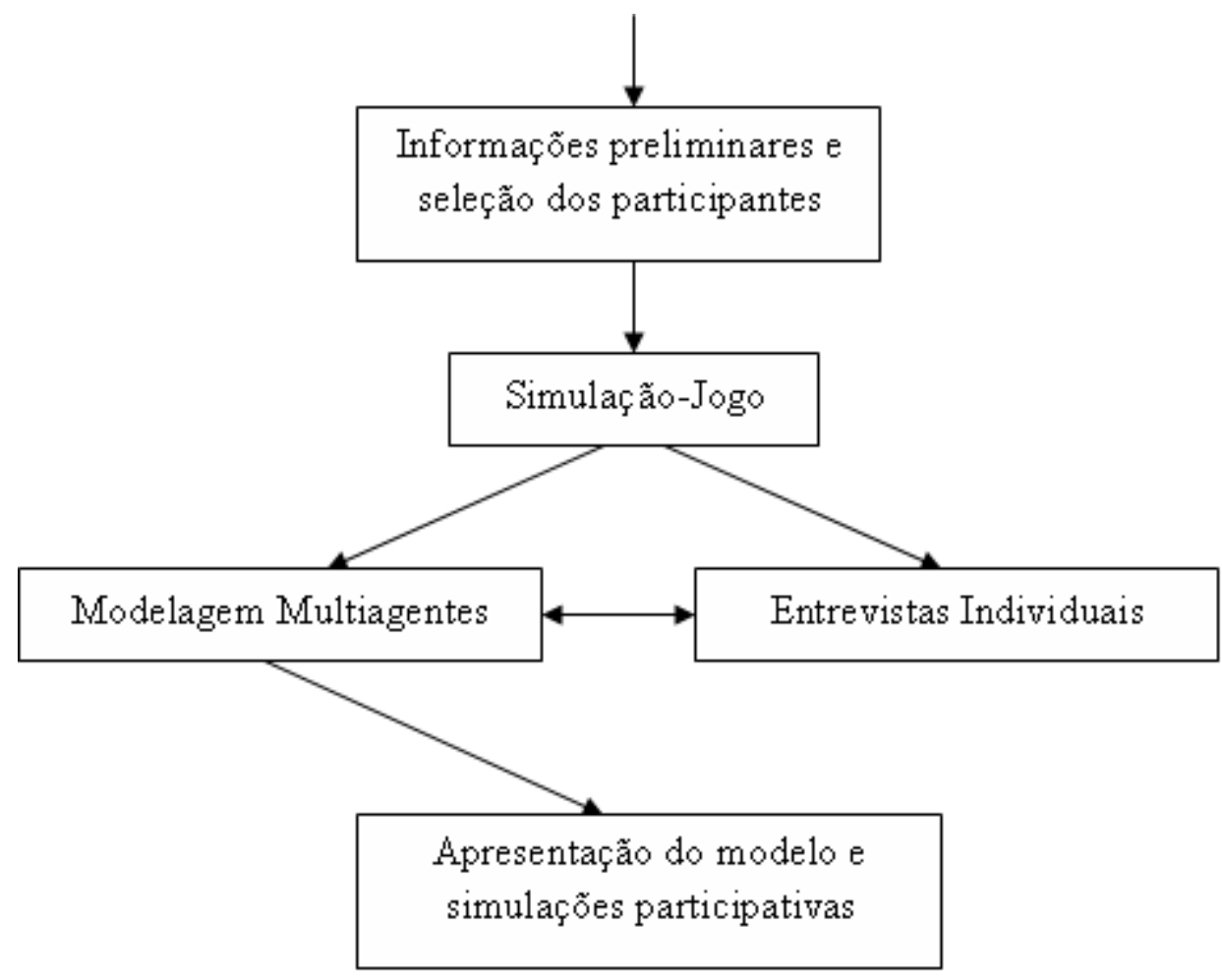

Figura 10: Etapas da Metodologia Samba-Week (BOISSAU; CASTELLA, 2003).

entrevistados irão comparar uma situação real que vivem com a situações criadas no jogo, a fim de verificar a similariedade do jogo com a realidade.

- Modelagem Multiagentes: em paralelo com as entrevistas, é desenvolvido um modelo multiagentes para representar a etapa de Simulação-Jogo no computador. O principal objetivo de desenvolver um modelo computacional é apresentar a evolução do ambiente físico a partir das ações escolhidas. Normalmente, na etapa de Simulação-Jogo, não é possível realizar muitas rodadas do jogo, de forma que, os participantes não podem visualizar a evolução do ambiente. As ações coletadas na etapa de Entrevistas Individuais também são implementadas na simulação.

O Samba-Week apresenta os seguintes aspectos:

- Técnicas Utilizadas: RPG e MABS isoladamente;

- Operador: após realizado o RPG não computacional, implementa-se o MABS e há um operador para apresentar as simulações realizadas;

- Objetivos: habilitar o diálogo entre os atores no âmbito da agricultura;

- Público-alvo: agricultores, tendo sido testado com agricultores no norte do Vietnã; 
- Avaliação: não existe um processo de avaliação explícito.

\subsection{SylvoPast}

SylvoPast é um modelo para simular estratégias opostas existentes nos planos de gerenciamento silvopastoris, de forma a prevenir o grande número de incêndios nas florestas do Mediterrâneo (ETIENNE, 2003). O modelo implementado é baseado em uma área florestal e em regras de gerenciamento para dois tipos de agentes: os criadores de ovelhas e os reflorestadores, que sofrem o mesmo problema (incêndio), porém têm objetivos diferentes.

O principal objetivo do modelo é identificar qual estrutura é mais eficiente para atender aos objetivos e comparar diversas estratégias de negociação entre os dois agentes. O modelo busca identificar estados de equilíbrio e comparar formas onde reflorestadores e criadores de ovelhas possam compartilhar informações.

A negociação sobre que ação cada agente irá escolher é realizada a partir de RPG. No caso, o jogo é realizado entre dois jogadores, que assumem o papel de reflorestador e de criador de ovelhas e têm que defender os objetivos estabelecidos no jogo para o seu papel, a partir de um conjunto de possíveis ações. Os objetivos do jogador "criador de ovelhas" são definir a rota e o período de pastagem do rebanho, a fim de aumentar o número de animais e utilizar a pastagem de forma correta (esperar até que atinga o tamanho correto para o uso). Os objetivos do jogador "reflorestador" são reduzir o risco de incêndio e produção de madeira.

A cada rodada do jogo, os jogadores têm um curto tempo para decidir qual ação irão realizar e em qual local. Depois, devem inserir suas ações no sistema e visualizar as transformações realizadas e verificar se estão obtendo êxito em seus objetivos. Para que o jogo não se torne monótono, após um determinado número de rodadas (que é randômica para cada novo jogo), um incêndio aparecerá em uma das células (também escolhida de forma randômica), gerando um novo cenário, ao qual os jogadores deverão analisar e escolher suas ações. A Figura 11 apresenta a interface de entrada de dados do SylvoPast (ETIENNE, 2003).

O SylvoPast é um jogo bastante interessante, pois coloca os jogadores em situações contrárias (com objetivos opostos), gerando discussão. Porém, como são apenas dois jogadores, a problemática de cada jogador está em saber o que o outro irá fazer. Assim, o processo de negociação é mais curto e gera menos polêmica do que em um grupo maior, onde, muitas vezes, não é possível "controlar" as ações dos outros jogadores de forma tão simplificada. 


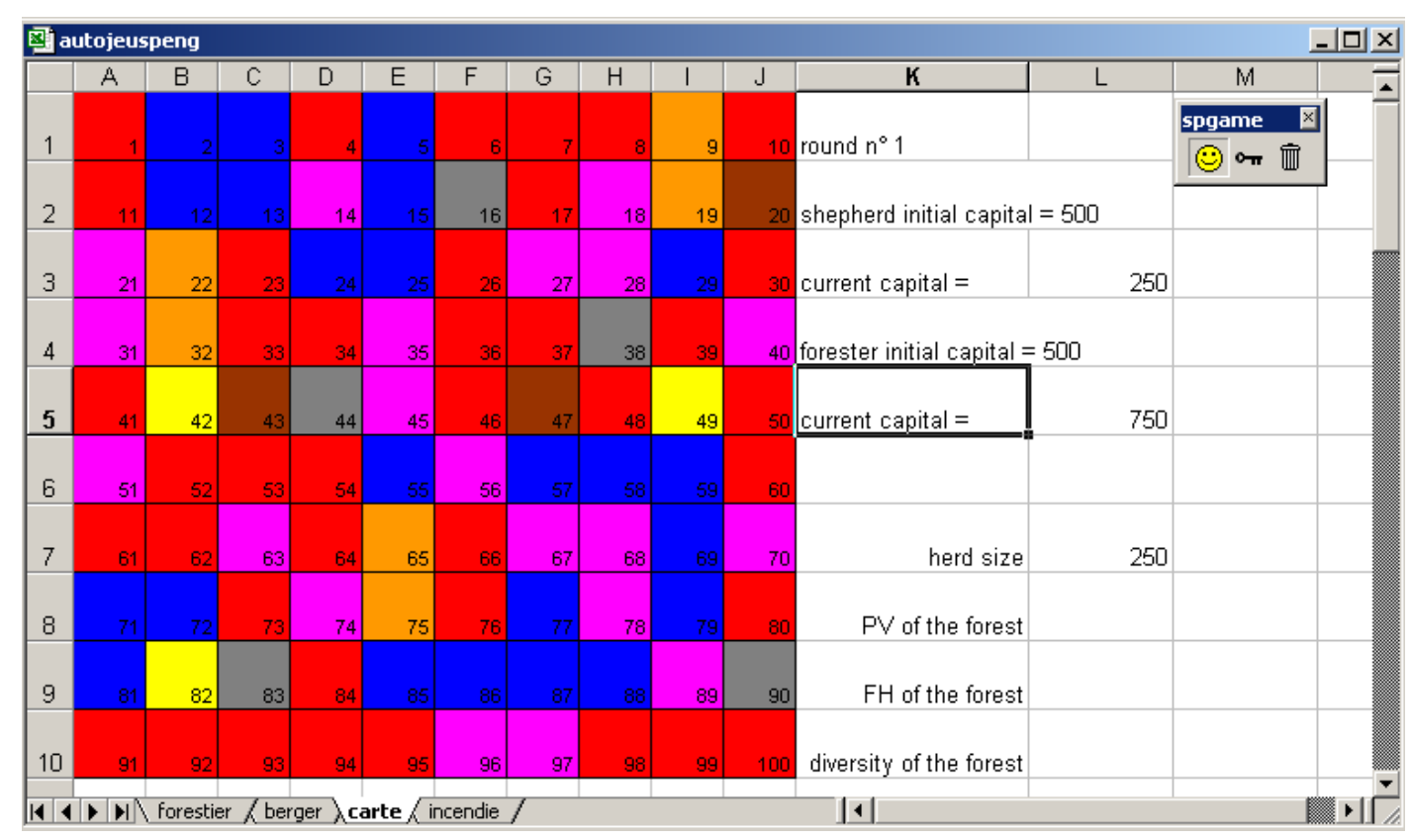

Figura 11: Interface de Entrada de Dados do SylvoPast (ETIEnNE, 2003).

O SylvoPast apresenta os seguintes aspectos:

- Técnicas Utilizadas: GMABS;

- Operador: os próprios jogadores inserem os dados no simulador MABS;

- Objetivos: identificar melhor estrutura para atender objetivos dos jogadores participantes;

- Público-alvo: pessoas envolvidas em atividades silvopastoris;

- Avaliação: não existe um processo de avaliação explícito.

\subsection{Análise Comparativa}

Dentre os quatro exemplos apresentados nas seções anteriores, o único que pode ser considerado no escopo deste trabalho, por trabalhar com a metodologia GMABS, é o SylvoPast. Os outros exemplos apresentados (Desafio das Águas, SHADOC e SAMBA-Week) também são importantes, pois auxiliaram na compreensão das técnicas, mesmo que de forma isolada.

Um dos aspectos mais complicados no processo de negociação no domínio de gestão de recursos naturais é a quantidade de atores. No SylvoPast, que trabalha com apenas dois jogadores, representando os atores criadores de ovelhas e os reflorestadores, a problemática da negociação fica muito restrita em um jogador saber o que o outro irá fazer, simplificando muito o processo. O jogo é muito 
interessante para entendimento do problema proposto, mas não é muito realista, pois o número de atores envolvidos no processo de negociação real é muito maior. Porém, uma vantagem muito grande do jogo é facilidade de realização do jogo, pois necessita apenas de dois jogadores.

No capítulo 5, será apresentado um dos protótipos desenvolvidos neste trabalho, denominado JogoMan. Este protótipo também se baseia na metodologia GMABS, mas possui um diferencial ao SylvoPast: são necessários 14 jogadores para que o jogo ocorra. Quando o número de jogadores cresce, também cresce a complexidade das negociações. Contudo, a veracidade do jogo, ou seja, sua similariedade com a realidade, também cresce. Desta forma, quando se deseja desenvolver um RPG, devem-se avaliar os objetivos propostos para o mesmo: um jogo deve ser mais realista e consequentemente, mais complexo, ou um jogo deve ser mais simples e de fácil realização.

\subsection{Considerações Finais}

Este capítulo apresentou quatro formas de utilização das técnicas de MABS e de RPG, aplicadas no contexto de recursos naturais. Estas técnicas podem ser utilizadas separadamente ou de forma integrada. Na seção 3.5 foi apresentada uma análise comparativa das quatro formas de uso das técnicas, dando ênfase ao último exemplo apresentado, o Sylvopast, que utiliza a metodologia GMABS, foco de estudo neste trabalho.

Um aspecto fundamental, porém ausente nos quatro exemplos apresentados neste capítulo, é a definição de um processo de avaliação dos resultados decorrentes do uso destas técnicas. Este aspecto é discutido no próximo capítulo. 


\section{Avaliação de Sistemas Computacionais}

O objetivo deste trabalho é a definição de uma arquitetura para a inserção de jogadores virtuais na metodologia GMABS. Para verificar se este objetivo foi bem cumprido, é necessário realizar algum tipo de avaliação do estudo de caso a ser desenvolvido. Contudo, para as áreas de RPG ou de MABS não foram encontrados trabalhos que realizassem a avaliação dos mesmos, como verificado no capítulo anterior. Assim, para que se possa definir alguma forma de avaliação para a metodologia GMABS com jogadores virtuais, decidiu-se estudar alguns métodos de avaliação utilizados em computação, que são apresentados na seção 4.1. Também foi analisado como outras áreas de estudo, correlacionadas ao foco de estudo deste trabalho, realizam a avaliação de seus sistemas. Na seção 4.2 esta análise é apresentada. Finalmente, as considerações finais deste capítulo são mostradas na seção 4.3 .

\subsection{Métodos de Avaliação}

Segundo Stern (STERN, 1991), pode-se considerar avaliação como qualquer atividade que habilita as pessoas envolvidas a aprender e realizar julgamentos sobre o assunto a ser avaliado. Contudo, esta visão sobre avaliação está relacionada à avaliação de programas sociais e/ou educacionais.

Na área de computação, avaliação é normalmente utilizada com forma de entender um sistema computacional e compará-lo a outros sistemas, dizendo que o mesmo é melhor (ou superior) a outros, ou para determinar se o sistema está "completo", segundo um conjunto de critérios pré-determinados. Para Hook et al. (HOOK, 1998; HOOK; SVENSSON, 1999), a avaliação de sistemas computacionais é uma tarefa difícil. O grande problema é definir os critérios de avaliação, que são extremamente subjetivos e dependentes do tipo de aplicação, e provar que os mesmos são válidos para todas as possíveis ações que o sistema está pré disposto 
a executar (completude).

Alguns métodos de avaliação foram especificamente desenvolvidos para a área de computação. Contudo, outros métodos foram trazidos de outras ciências, como a psicologia e a antropologia. A utilização de um método ou outro depende do objetivo desejado e do contexto do trabalho. Os métodos podem propor uma avaliação completa do sistema ou a análise de alguns dos aspectos do mesmo, como interface ou programação.

Existem ainda métodos que avaliam o desempenho do sistema, os chamados performance analysis. Contudo, o desempenho do sistema não é considerado um aspecto crítico para execução da metodologia GMABS, visto que a única operação que exige maior processamento de informações, e consequentemente, melhor desempenho, é o processamento das ações escolhidas (passo número 4 da Figura 2). Desta maneira, este tipo de método de avaliação não será analisado neste trabalho.

Segundo Ramage (RAMAGE, 1999), na literatura, podem-se dividir os métodos de avaliação em três grandes grupos: os baseados na etnografia (antropologia), onde o foco está na organização social do trabalho e os efeitos da tecnologia sobre o trabalho; os baseados na psicologia, focando na interação entre os usuários frente a tecnologia; e os baseados na construção de sistemas, que analisam formas de melhor implementar o sistema, ou seja a tecnologia, para os usuários.

\subsubsection{Métodos Baseados na Etnografia}

Existem três métodos baseados na etnografia:

1. Etnometodologia: baseado na sociologia, este método é o mais realista para avaliar um sistema. O novo sistema é colocado no local de trabalho dos usuários por um período de tempo prolongado. Um sistema pode ser qualquer processo, não necessariamente um sistema computacional. Por exemplo: uma nova lei fiscal em um setor administrativo exige que os funcionários alterem sua metodologia de trabalho. Normalmente, a monitoração dos dados é feita por meio de vídeos e anotações do avaliador. O foco está em detalhar o que as pessoas estão fazendo passo-a-passo, a fim de entender como foram realizadas as suas tomadas de decisão. O tempo de imersão do sistema pode demorar meses ou até mesmo anos. É muito utilizado em psicologia social. Contudo, no desenvolvimento e testes de sistemas de informação, o tempo necessário normalmente é muito longo, o que, muitas 
vezes, inviabiliza sua utilização (ROSS S.; ROGERS, 1995).

2. Análise de Conversação e de Interação: também baseado na sociologia, este método estuda as interações reais de um grupo de usuários, a partir de suas conversas e interações. A idéia é conseguir dividir os usuários em categorias (grupos sociais), principalmente visando o aumento da interação entre as pessoas e das pessoas com a nova tecnologia (WINOGRAD; FLORES, 1986; ROSS S.; ROGERS, 1995). Os avaliadores não ficam no mesmo ambiente que os usuários durante a avaliação, para que estes não se sintam inibidos por estarem sendo avaliados. Normalmente, o avaliador fica em uma sala em separado observando, ou utiliza-se de vídeos para realizar a avaliação dos usuários.

3. Análise de Breakdown: baseado na ciência da computação e na psicologia, onde um breakdown é definido como qualquer situação onde o usuário focaliza suas atividades em uma determinada tarefa do sistema. A idéia deste método é verificar como o usuário interage com o sistema para execução de determinadas tarefas. O avaliador escolhe a seqüência de tarefas a serem executadas pelos usuários, e verifica como cada uma delas é executada. É útil para identificar problemas associados a Interface Humano-Computador (IHC), onde analisa-se a comunicação do sistema como o usuário (RAMAGE, 1999).

\subsubsection{Métodos Baseados na Psicologia}

Os dois principais métodos baseados na psicologia são os seguintes:

1. Experimentos em Laboratório: baseado na psicologia social e/ou cognitiva, porém muito utilizado na área de Computer Supported Corporative Work (CSCW). Este método de avaliação procura armazenar dados quantitativos sobre um fator específico, ignorando os outros fatores existentes. Os usuários têm que executar uma série de tarefas e o avaliador observará se o fator escolhido para análise está sendo satisfeito. Por exemplo: em um sistema computacional, o avaliador deseja verificar se as "teclas de atalho" são úteis e fáceis de acessar. Assim, o interesse do avaliador estará apenas na forma como os usuários executam as tarefas utilizando (ou não) teclas de atalho, não se importando com as outras atividades dos usuários.

Para Twidale et al. (TWIDALE; RANDALL; BENTLEY, 1994), este método deve ser utilizado nas fases iniciais de avaliação de CSCW com estudantes, 
para verificação de problemas de usabilidade padrão, pois quando testado com usuários reais (normalmente com menos tempo para realização de testes), os problemas básicos já estarão solucionados (ROSS S.; ROGERS, 1995). Como no método de Análise de Breakdown, o foco de análise está apenas em uma tarefa por vez, o que restinge a avaliação realizada pelo mesmo (WINOGRAD; FLORES, 1986).

2. Entrevistas, Questionários, Grupos de Trabalho e Feedback: baseado na psicologia social, onde diversas informações sobre as experiências dos usuários com o sistema podem ser obtidas a partir de suas reações ao utilizar o mesmo. É normalmente utilizado para capturar dados para análises posteriores. Um exemplo de utilização é em pesquisa de mercado, onde dados sobre um produto são coletados junto ao consumidor para futuras análises de como vender o produto. A subjetividade deste tipo de método (normalmente perguntas abertas, que expressam as opiniões pessoais dos usuários) pode ser útil, porém também é limitada, pois em grandes grupos de usuários, checar as consistências entre as informações é bastante complicado (BECK; BELLOTTI, 1993).

\subsubsection{Métodos Baseados na Construção de Sistemas}

Os três métodos baseados na construção de sistemas que foram analisados são os seguintes:

1. Avaliação heurística (NIELSEN, 1993): normalmente utilizada na área de IHC. Esta avaliação é baseada nas reações, intuições e predições do avaliador, ou seja, é uma forma de avaliação subjetiva/intuitiva. O sistema em teste está pronto, porém quando os usuários realizam o teste, o avaliador deve verificar consistência, controle do usuário, aprendizagem, memorização, recuperação de erro, eficiência e satisfação subjetiva, a fim de detectar problemas no sistema. Para Ross et al. (ROSS S.; ROGERS, 1995), a avaliação heurística é uma parte essencial de qualquer processo de desenvolvimento, pois auxilia de forma eficaz na correção de erros.

2. Testes de Usuário: é a forma mais utilizada em IHC, pois realiza testes com usuários reais em um contexto semi-realista. A idéia é verificar no sistema usabilidade ou funcionalidades, a partir de questionários e feed back dos usuários. Desta forma, o avaliador é o próprio usuário, não existindo outra pessoa a observar e/ou anotar. Os dados coletados, normalmente, 
são qualitativos. Segundo Bannon (BANNON, 1991), os testes de usuário são uma parte fundamental no processo iterativo de desenvolvimento, mas a elaboração do teste deve ser realizado com atenção, visando os objetivos a serem alcançados pelo sistema. Contudo, existem problemas com a descontextualização e não naturalidade dos experimentos, pois os testes são realizados fora do contexto real.

3. Protótipo Iterativo / Desenvolvimento Participativo ${ }^{1}$ : consiste em construir um sistema em pequenas partes, testar separadamente cada uma delas com os usuários e realizar melhorias a partir dos testes realizados (NIELSEN, 1993). Assim, os usuários não têm uma visão global do sistema, mas apenas de pequenas partes do mesmo. Também neste método, o usuário é o próprio avaliador, sem a intervenção de outra pessoa durante a realização dos testes. É um método muito utilizado em IHC e faz com que os usuários se envolvam no processo de desenvolvimento, o que tende a facilitar a futura implementação do sistema na empresa, pois os usuários já possuirão afinidade com o sistema.

\subsubsection{Análise Comparativa}

Os métodos de avaliação anteriormente descritos podem ser analisados a partir de três aspectos:

1. Uso do sistema pelos usuários: a utilização do sistema é realizada de forma livre ou guiada para alguns aspectos, como uma seqüência de tarefas;

2. Quem avalia: existe uma pessoa para avaliar o usuário e sua interação com o sistema, ou o próprio usuário é quem realiza toda a avaliação;

3. Tipo de avaliação: os resultados da avaliação são qualitativos ou/e quantitativos

Desta forma, a Tabela 3 apresenta uma síntese dos métodos, a partir destes aspectos. Segundo esta tabela, alguns métodos não possuem variação entre os aspectos analisados, como Etnometodologia, Experimentos em Laboratório e Protótipo Iterativo/Desenvolvimento Participativo. Os outros métodos podem variar em alguns dos aspectos. O método de Análise de Conversação e

\footnotetext{
${ }^{1}$ Ramage (RAMAGE, 1999) utiliza esta definição, mas na verdade esta difere das anteriores, pois se trata mais de um método de desenvolvimento de sistemas do que um aprimoramento de um sistema a partir dos testes.
} 
de Interação pode usar uma avaliação qualitativa ou quantitativa, dependendo de como os "grupos sociais" foram formados. Se os parâmetros utilizados para a criação foram subjetivos, como empatia com determinado colega de trabalho, tem-se uma avaliação qualitativa. Porém, se os parâmetros forem objetivos, como a necessidade de troca de informações com outra pessoa ou o número de acessos a informação definida por outro colega, tem-se uma avaliação quantitativa. O mesmo tipo de dependência, relacionada ao tipo de avaliação, pode-se observar nos métodos Análise de Breakdown e Avaliação Heurística, onde o tipo de tarefa a ser executada pode ser avaliada de forma qualitativa ou quantitativa.

\begin{tabular}{|c|c|c|c|}
\hline \hline Método & Uso do sistema & Quem avalia & Tipo de aval. \\
\hline \hline Etnometodologia & Livre & Avaliador Externo & Qualitativo \\
\hline Anál. Conversação & Livre & Avaliador Externo & Qual./Quant. \\
\hline Anál. Breakdown & Seq.Tarefas & Avaliador Externo & Qual./Quant. \\
\hline Exp. Laboratório & Seq.Tarefas & Avaliador Externo & Quantitativa \\
\hline Entrevistas & Livre & Aval. Externo/Próp.Usuário & Qualitativa \\
\hline Aval. Heurística & Livre & Avaliador Externo & Qual./Quant. \\
\hline Testes de Usuário & Livre/Seq.Tarefas & Próprio Usuário & Qualitativa \\
\hline Prototipo Iterativo & Livre & Próprio Usuário & Quantitativa \\
\hline \hline
\end{tabular}

Tabela 3: Síntese dos Métodos de Avaliação Analisados.

Já o método de Entrevistas, Questionários, Grupos de Trabalho e Feedback varia na realização da avaliação, pois quando são realizados questionários, normalmente a avaliação é realizada pelo próprio usuário e quando são realizadas entrevistas, há um avaliador externo.

No método de Testes de Usuários pode haver variação em como é realizada a utilização do sistema: pode ser solicitada a execução de uma seqüência de tarefas ou o uso pode ser livre. Tal escolha irá depender dos objetivos que se pretende alcançar com a avaliação.

\subsection{Aplicação dos Métodos em Áreas Correla- cionadas}

O foco de aplicação deste trabalho está nas áreas de jogos e simulação computacional. Trabalhos envolvendo simulação computacional, normalmente, analisam a variação de alguns fatores do modelo no decorrer dos ciclos de simulação (NANDALAL; SIMONOVIC, 2003; THOYER et al., 2001). Este tipo de avaliação está baseada no método Análise de Breakdown e/ou Experimentos em Laboratório, onde cada fator é analisado separadamente. Esta análise é quantitativa, 
pois a simulação é representada por um conjunto finito de termos, diferentemente de questionários abertos aos usuários, onde a análise se torna qualitativa, pois o conjunto de possíveis respostas é indeterminado.

Já na área de jogos educacionais (computacionais ou não), a eficiência dos mesmos, e como medi-la, é um problema que vem sendo abordado há longo tempo (BREDEMEIER; GREENBLAT, 1981; DORN, 1989; EGENFELDT-NIELSEN, 2004; HOGLE, 1996). Estes trabalhos abordam a subjetividade da avaliação de jogos educacionais, pois o trabalho realizado com pessoas envolve reações diferentes, que são dependentes das experiências e convívio social que cada uma possui. Desta forma, cada pessoa pode aprender algo diferente e em níveis diferentes. Uma forma de avaliação muito utilizada desta área é a partir de questionários: um aplicado antes da realização do jogo e outro ao término. Este tipo de avaliação está baseada no método de Entrevistas, Questionários, Grupos de Trabalho e Feedback. Porém, o trabalho de Cárdenas e Ostrom (CARDENAS; OSTROM, 2004) apresenta a avaliação de jogos a partir de níveis de interação entre os usuários. Estes níveis determinam o que os usuários aprenderam e ensinaram uns aos outros durante o jogo (como foi realizada a cooperação entre eles). Esta avaliação está baseada no método de Análise de Conversação e de Interação, pois em cada nível, são formados "grupos de trabalho".

Especificamente para RPG, não foram encontrados trabalhos sobre a sua avaliação. Contudo, entende-se que em jogos do tipo RPG, a avaliação também fica dependente dos objetivos que o jogo tiver, como aprendizado, auxílio à negociação, etc., e desta forma, deve-se escolher um dos métodos de avaliação disponíveis. Devido à subjetividade envolvida no processo de avaliação deste tipo de jogo, fica quase impossível realizar comparação entre jogos. Isto só poderia acontecer se estes jogos tivessem os mesmos objetivos, parâmetros, regras e jogadores, o que não é muito factível. Como o principal objetivo deste trabalho é desenvolver uma arquitetura onde Jogadores Virtuais estarão inseridos em RPG, a avaliação da inserção de jogadores virtuais na metodologia GMABS é vital para validar a proposta.

A área de Interfaces Inteligentes (Agentes Assistentes) tem algumas correlações com a idéia da inserção de jogadores virtuais. Em Interfaces Inteligentes, o sistema é apresentado ao usuário de maneira dinâmica e autônoma, auxiliando na realização de tarefas, dando dicas, etc. Da mesma maneira, deseja-se que os Jogadores Virtuais realizem suas interações com os outros jogadores e com o ambiente de forma autônoma e dinâmica. 
O trabalho de Hook e Svensson (HOOK; SVENSSON, 1999) apresenta uma maneira de avaliar sistemas hipermídia (navegação em textos $W e b$ ). Para isso, alguns critérios foram escolhidos, como o número de visitas a cada link, o tempo para completar uma tarefa e quanto o usuário consegue lembrar da estrutura de informação já acessada (por onde já passou). Segundo os autores, os dois primeiros critérios são bons parâmetros para esta área de pesquisa e são fáceis de calcular. Já o terceiro parâmetro retorna mais informação, mas sua avaliação é mais subjetiva. Algo importante a ressaltar neste trabalho é que os autores acreditam que todas as atividades podem ter uma melhor avaliação se desenvolvidas em uma interface mais divertida e que os usuários não saibam que estão sendo avaliados, a fim de reduzir ansiedade e pressão psicológica. Este trabalho é baseado no método de Análise de Breakdown.

Já no trabalho de Vivacqua e Lieberman (VIVACQUA; LIEBERMAN, 2000) foi desenvolvido um assistente para programadores Java, o Expert Finder. A avaliação deste assistente foi realizada com um grupo de 10 usuários que deveriam responder questões sobre Java. O assistente calcula um "nível de conhecimento" de cada usuário, levando em conta o total de vezes que cada usuário utiliza uma classe, método ou biblioteca para responder às questões, ou seja, o número de tentativas até dar a resposta final. Existem três níveis de conhecimento: novice, intermediate e advanced ou expert. Quanto menos acesso aos dados, maior o nível. Após calcular esse nível, é realizada uma comparação entre as respostas corretas e o nível determinado de conhecimento de cada usuário, e uma das conclusões foi que os usuários foram colocados em níveis corretos, pois $85 \%$ das respostas corretas estavam relacionadas à usuários ditos "experts". Este trabalho é baseado no método de Experimentos em Laboratório, pois analisa apenas um aspecto (número de vezes que utilizou as informações) e é totalmente quantitativo.

Outro trabalho que envolve as áreas de interfaces e agentes inteligentes é apresentado por Pynadath e Tambe (PYNADATH; TAMBE, 2003), para utilização em domínios onde haja interação entre agentes de software e humanos, com a utilização do framework "Teamcore". Um dos exemplos de aplicação é a coordenação de atividades agendadas em um PDA, onde um agente de software monitora o agendamento das atividades de um usuário em seu PDA, a partir de uma interface inteligente, dando dicas, apresentando conflitos, etc. A avaliação realizada para este domínio levou em conta apenas aspectos computacionais: robustez do sistema; forma de programação do sistema; e adaptação dinâmica dos agentes de software. Para demonstrar robustez, o sistema ficou rodando, sem falhas, por três meses ininterruptos. Relacionado à forma de programação, a troca 
de mensagens realizada pelo sistema foi pequena e as rotas escolhidas para entrega e recebimento das mesmas foram muito boas (normalmente, as mais curtas), comprovando que o sistema foi implementado visando a otimização da troca de mensagens. Relacionado ao terceiro aspecto, adaptação dos agentes de software, os autores justificaram que, por serem implementados de forma dinâmica, estes agentes tiveram trocas de mensagens e rotas de entrega/recebimento reduzidas. Este trabalho baseia-se no método de Testes de Usuários.

Foram analisados também trabalhos de avaliação sobre "Equipes Virtuais", que envolvem as áreas de pesquisa de Administração e a Psicologia (MUCHINSKY, 2004; AVOLIO et al., 2001; ALCHIERI; CRUZ, 2003). Segundo Hassegawa (HASSEGAWA, 2002), equipes virtuais são grupos de pessoas, guiadas por um objetivo comum, que se interagem através de tarefas interdependentes. Porém, diferentemente das equipes tradicionais, onde os membros estão próximos fisicamente, as equipes virtuais funcionam através das fronteiras de espaço, tempo e organização e cujas ligações são estreitadas e fortalecidas através das tecnologias de comunicação. Um aspecto muito importante analisado pelas equipes virtuais é a negociação e como este processo pode acontecer de forma assíncrona entre os membros da equipe (MUCHINSKY, 2004). No caso dos Jogadores Virtuais, este aspecto deve ser avaliado, pois quando incluídos no RPG, não terão comunicação direta (face-a-face) como os outros jogadores, como acontece em RPGs convencionais (jogos de mesa, com todos os jogadores presentes em um mesmo local). Quando o jogo for realizado via $W e b$, todos os jogadores, sejam reais ou virtuais, não terão contado direto na interação e tomada de decisão. A forma de avaliação realizada por equipes virtuais nos trabalhos analisados (AVOLIO et al., 2001; HASSEGAWA, 2002; FJERMESTAD, 2004; ZHANG; FJERMESTAD; TREMAINE, 2005) foi baseada no método de Entrevistas, Questionários, Grupos de Trabalho e Feedback, a partir de questionários. Estes questionários analisaram alguns aspectos quantitativos, como idade ou tempo que executa a atividade, e alguns aspectos qualitativos, como espírito de equipe ou confiança mútua.

Alguns trabalhos envolvendo o processo de negociação via Internet foram analisados. Por exemplo, Kersten e Noronha (KERSTEN; NORONHA, 1999) apresentam um sistema para trabalhar com negociações via Internet utilizando o procotolo de Raiffa (apresentado na seção 2.4.2) como base teórica para entender as diferenças de negociação relacionadas as diferentes culturas e países de origem dos participantes. Os autores ressaltam que este tipo de análise só é possível graças a Internet, pois seria praticamente impossível reunir pessoas de países distantes, como nos testes realizados (Estados Unidos, Índia, China, etc), 
em um mesmo local para realização de negociações face-a-face. Toda a análise do trabalho é quantitativa, baseada nos arquivos de Log dos usuários. Com estes dados, os autores tentaram estabelecer perfis de comportamento durante as negociações de acordo com a nacionalidade do participante. O trabalho conclui que o computador é uma ferramenta essencial para o estudo das negociações e que negociações realizadas via Internet são mais eficientes, pois os participantes não agem emocionalmente em suas decisões, como ocorre normalmente em negociações facea-face. Também Peppet (PEPPET, 2002) afirma que negociações via Internet são mais produtivas, pois as pessoas sentem-se mais a vontade em expressar suas opiniões à distância. Em negociações face-a-face pode haver constrangimentos ou vulnerabilidade de alguns participantes, e percebendo isso, outros participantes podem utilizar estes fatos a seu favor na negociação. Estes exemplos de negociação via Internet trabalham de forma assíncrona, onde a primeira negociação é colocada em "jogo" e os participantes devem organizar suas idéias e enviar propostas e aguardar contra-propostas ou aceitação/rejeição das mesmas. Os trabalhos realizam análises quantitativas das negociações realizadas e concluem que os participantes, além de realizarem mais propostas em negociações via Internet, também gastam mais tempo organizando estas propostas, comparativamente a negociações realizadas face-a-face. Outros trabalhos interessantes, envolvendo negociação via Internet, podem ser encontrados em: (KROVI; GRAESSER; PRACHT, 1999; COMUZZI; PERNICI, 2004). Todos estes trabalhos baseiam-se no método de

\section{Análise de Conversação e de Interação.}

\subsection{Considerações Finais}

Este capítulo apresentou diversos métodos para avaliação de sistemas computacionais e uma análise comparativa entre estes métodos. Como não foram encontrados trabalhos que realizassem avaliação para a metodologia GMABS, foram analisados alguns trabalhos em áreas correlacionadas e verificados quais os métodos de avaliação que foram utilizados nestes trabalhos.

Os métodos aqui analisados e suas aplicações em áreas correlacionadas são extremamente importantes para a definição da metodologia de análise a ser adotada neste trabalho. Esta metodologia irá utilizar os métodos Análise de Conversação e de Interação e Entrevistas, Questionários, Grupos de Trabalho e Feedback e será melhor detalhada no capítulo 9.

Na Parte II, apresentada a seguir, a abordagem proposta neste trabalho é descrita em mais detalhes. 


\section{Parte II}

\section{Abordagem Proposta}




\section{Protótipo JogoMan}

Este capítulo apresenta o primeiro protótipo desenvolvido neste trabalho, referente à atividade número 2 da metodologia descrita na seção 1.3 e denominado JogoMan (Jogo dos Mananciais). Este protótipo tem por objetivo auxiliar no entendimento do domínio do problema escolhido, gestão de recursos naturais, bem como da utilização da metodologia GMABS. A seção 5.1 descreve os objetivos deste protótipo. Na seqüência, a descrição detalhada do jogo é apresentada na seção 5.2. A análise dos resultados obtidos nos testes é então mostrada na seção 5.3. Finalmente, na seção 5.4, apresentam-se as considerações finais deste capítulo.

\subsection{Objetivos}

O JogoMan está inserido no contexto do Projeto Negowat ${ }^{1}$ e envolve problemas de gerenciamento de água e de solo em 3 diferentes cidades, bem como o gerenciamento da pressão urbana sobre esta região, sendo uma simplificação da realidade.

O nome, "Jogo dos Mananciais", deve-se ao fato das regiões de captação de água estarem em área de mananciais e de proteção ambiental. No caso do Projeto Negowat, a região de estudo é a Região Metropolitana de São Paulo, que tem grande parte de sua área sobre a região dos Mananciais do Estado de São Paulo.

O objetivo principal deste jogo é apresentar alguns dos aspectos que influenciam na poluição das águas dos mananciais, como pressão urbana e uso do solo. Este protótipo visa a educação ambiental e é um SADs-G, pois auxilia no processo de negociação de uma questão muito complexa: a gestão de recursos hídricos, onde todo sistema é interligado e ações individuais têm conseqüências sobre o coletivo.

\footnotetext{
${ }^{1}$ Descrito no capítulo 1.
} 


\subsection{Descrição Detalhada}

A implementação do protótipo foi realizada no simulador Cormas (CORMAS, 2006), que é uma ferramenta de MABS desenvolvida para utilização nas áreas de gestão de recursos naturais. Maiores detalhes deste simulador são apresentados na seção 8.2 .

A distribuição do espaço físico no JogoMan é bidimensional e é representada por uma matriz 8x8, contendo 64 lotes, distribuídos entre 3 cidades. Cada lote tem diferentes possibilidades de usos do solo, como agricultura ou floresta, e pertence a um proprietário (jogador). O jogo necessita de 14 jogadores, que desempenham quatro papéis diferentes: 3 Prefeitos (um para cada cidade), 1 Administrador da AguaPura (único para as três cidades), 9 Proprietários Particulares e 1 Representante dos "Sem Teto". Existem três níveis de administração: companhia de água e Representante dos Sem Teto (com nível global), cidades (com nível parcial, a partir dos Prefeitos) e Proprietários Particulares (nível individual). A Figura 12 apresenta dois possíveis níveis de administração do jogo: a divisão das cidades e a área global, representando os usos do solo existentes no cenário inicial do jogo.

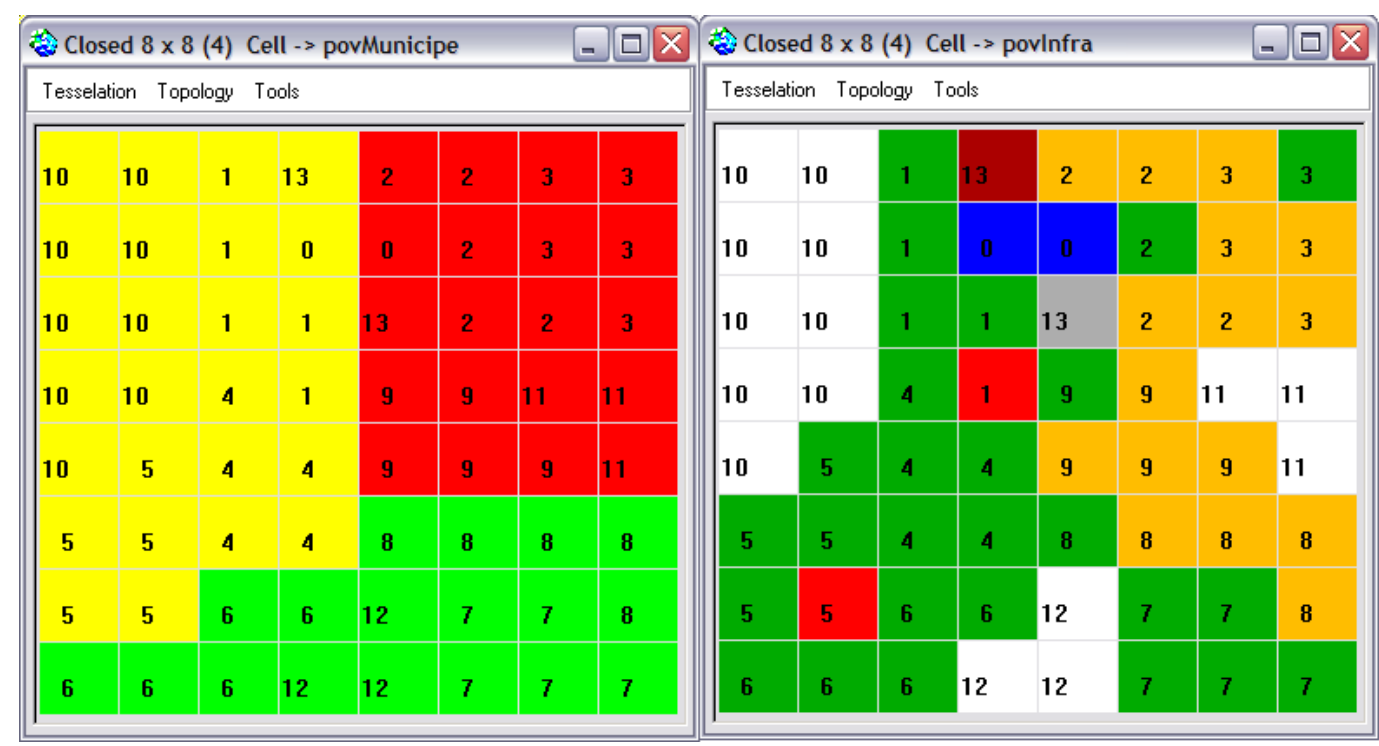

Figura 12: Níveis de Administração do JogoMan. A figura a esquerda representa a divisão das cidades (três diferentes cores). A figura a direita representa a divisão pelo uso do solo (diversas cores).

\subsubsection{Papéis Existentes}

Os quatro papéis do jogo são:

- Prefeitos: cada cidade tem uma atividade principal diferente: urbana, a- 
grícola ou de áreas preservadas (floresta). Desta maneira, o jogador que assumir o papel de Prefeito em cada uma destas cidades pode ter objetivos diferentes. Por exemplo, se a cidade C é uma área preservada, o jogador que assumir o papel de Prefeito de $\mathrm{C}$ pode persistir no objetivo de manter o município preservado.

Os Prefeitos podem construir novas infra-estruturas nas cidades: rede de água potável e de saneamento, escolas, postos de polícia e/ou hospitais. Por exemplo, durante o jogo, no processo de negociação, os Proprietários Particulares deveriam pedir, ou até mesmo exigir, que os Prefeitos implementem as infra-estruturas em suas cidades, visto que os proprietários pagam impostos.

Existem áreas urbanas consolidadas em cada uma das três cidades. Nestas áreas, existem pessoas morando e pagando impostos às prefeituras (IPTU). Na Figura 12 do lado direito, são as áreas em cor branca. Estas áreas não podem ser modificadas e ficam sob responsabilidade dos Prefeitos.

- Administrador da Companhia de Água: a companhia de água é uma empresa pública e pode construir as infra-estruturas de rede de água potável e de saneamento em qualquer área dos três municípios.

- Proprietários Particulares: cada um dos 9 proprietários possui 5 lotes, com diferentes usos do solo, como floresta, agricultura, sítio, etc. Para cada tipo de uso do solo, há diferentes valores de criação, retorno financeiro e geração de empregos. Este último aspecto é importante para os Prefeitos.

Cada lote pode ser vendido ou pode ter seu uso do solo modificado, sendo os valores de cada uso do solo mostrados na Tabela 4. Por exemplo, um Proprietário Particular que alterar o uso do solo de um de seus lotes para Agricultura não terá custos para "transformação" deste lote, e ao final de um turno de jogo obterá como retorno financeiro o valor de 1.200. A atividade de agricultura gerará ainda 10 novos empregos.

- Representante dos SemTeto: este jogador tem uma função especial no jogo, pois é responsável pela alocação de um número determinado de novas famílias em cada ciclo de simulação. Estas novas famílias chegam à região (o que caracteriza a pressão urbana) e podem ser alocadas em três diferentes locais:

1. Loteamentos regulares, onde os SemTeto são proprietários, pois compraram o lote de outro jogador. Estes lotes possuem infra-estruturas 
básicas de água e esgoto;

2. Loteamentos irregulares, onde os SemTeto também são proprietários, mas os lotes não possuem infra-estruturas básicas de água e esgoto;

3. Favelas, onde os SemTeto não são donos (são lotes invadidos) e não possuem infra-estruturas básicas de água e esgoto.

Dependendo da maneira que estas famílias forem alocadas, a qualidade e/ou quantidade de água da região é alterada.

\subsubsection{Tipos de Uso do Solo}

Os possíveis tipo de uso do solo do jogo, bem como os valores para criação, retorno financeiro e geração de empregos de cada tipo, são apresentados na Tabela 4. Os jogadores têm acesso às informações sobre os tipos de uso do solo, para que possam decidir sobre as ações a serem tomadas durante o jogo.

\begin{tabular}{|c|c|c|c|}
\hline \hline Tipo de Uso & Custo de Criação & Retorno Fin. & Empregos Ger. \\
\hline \hline Agricultura & 0 & 1.200 & 10 \\
\hline Agricultura Irrig. & 3.000 & 2.000 & 15 \\
\hline Campo & 0 & 0 & 0 \\
\hline Comércio & 50.000 & 10.000 & 100 \\
\hline Favela & 2.000 & 0 & 0 \\
\hline Floresta & 10.000 & 0 & 300 \\
\hline Indústria & 100.000 & 15.000 & 30 \\
\hline Loteamento & 25.000 & 0 & 0 \\
\hline Loteamento Irregular & 10.000 & 0 & 10 \\
\hline Plantação (eucaliptos) & 10.000 & 17.000 (antes 5 anos) & 30 \\
\hline Sítio & & 27.000 (após 5 anos) & 1.000 \\
\hline Urbano & 20.000 & 0 & 0 \\
\hline \hline
\end{tabular}

Tabela 4: Tipos e Valores dos Usos do Solo.

\subsubsection{Variáveis}

Durante o jogo, algumas variáveis são calculadas e armazenadas. Contudo, dependendo do papel desempenhado no jogo, algumas variáveis poderão estar disponíveis ou não aos jogadores. Tais variáveis foram propostas pelos participantes do Projeto Negowat ${ }^{2}$. As variáveis existentes no JogoMan são:

- Poupança: valores armazenados $(\$)$ por cada jogador durante o jogo. Cada jogador possui uma variável Poupança armazenada. Os valores iniciais para

${ }^{2}$ Citado no Capítulo 1. 
esta variável, conforme o papel que os jogadores desempenham no jogo, são os seguintes:

- Proprietários Particulares: \$2.000;

- Prefeitos: \$30.000;

- Administrador AguaPura: \$60.000;

- Representante dos SemTeto: \$0.

- Índice de Poluição do Reservatório: é realizado um cálculo a partir dos tipos de uso do solo em todos os lotes, a coleta e tratamento de esgoto e o número de famílias morando na região. Esta é a variável mais importante do jogo e está interligada à maioria das ações executadas no jogo, que influenciam na poluição na água. Apenas os jogadores no papel de Prefeitos e Administrador da AguaPura têm acesso a esta variável.

O valor inicial desta variável é de 4.800 "unidades de poluição", baseado em diversos fatores, como esgoto residencial e industrial, assoreamento do reservatório, etc. Este valor foi definido pelos especialistas do Projeto Negowat e é considerado um valor limite para poluição de um reservatório, relacionado ao custo $\mathrm{x}$ benefício do tratamento da água para se tornar potável. Sendo assim, os jogadores já iniciam o jogo com o reservatório em situação precária.

- Percentual de Famílias Conectadas à Rede de Água: relação entre o número de famílias com acesso à rede de água potável e o número total de famílias em cada cidade. Apenas os jogadores no papel de Prefeitos e Administrador da AguaPura têm acesso a esta variável.

Inicialmente, todas as famílias que moram em lotes onde o uso do solo é urbano possuem conexão à rede de água. Assim, praticamente $100 \%$ das famílias está conectada a rede de água.

- Percentual de Famílias Conectadas à Rede de Esgoto: relação entre o número de famílias com acesso à rede de esgoto e o número total de famílias de cada cidade. Apenas os jogadores no papel de Prefeitos e Administrador da AguaPura têm acesso a esta variável.

Inicialmente, apenas algumas famílias que moram em lotes onde o uso do solo é urbano possuem conexão à rede de esgoto. Assim, o percentual inicial de famílias conectadas à rede de esgoto é de aproximadamente $40 \%$. 
- Percentual de Serviços Urbanos: relação entre o número de famílias com acesso aos serviços públicos de escolas, postos de saúde e postos de polícia e o número total de famílias de cada cidade. Apenas os jogadores no papel de Prefeitos têm acesso a esta variável.

Inicialmente, esta variável é diferente entre as três cidades: no município A a situação é mais precária, com apenas $50 \%$ das famílias com acesso aos serviços; nos municípios B e C a situação é um pouco melhor, com certa de 84\% das famílias com acesso aos serviços.

- Percentual de Famílias Morando em Favelas: relação entre o número de famílias morando em lotes onde o uso do solo é favela e o número total de famílias de cada município. Apenas os jogadores no papel de Prefeitos têm acesso a esta variável.

Inicialmente, não existem famílias morando em favelas, sendo o valor desta variável de $0 \%$.

- Percentual de Desemprego: relação entre o número de pessoas empregadas e o número total de pessoas de cada município. Apenas os jogadores no papel de Prefeitos têm acesso a esta variável. Inicialmente, esta variável é diferente entre as três cidades: no município A a situação é mais precária, onde $10 \%$ das pessoas estão desempregadas; nos municípios B e C, não há desemprego, e a taxa de desemprego é de $0 \%$.

- Percentual de Desenvolvimento Social: calculado a partir da seguinte relação: $\frac{(\% \text { RedeAgua }+\% \text { RedeEsgoto }+\% \text { ServicosUrbanos }-\% \text { FamiliasFavelas })}{3}$

Onde:

\%RedeAgua é o percentual de Famílias Conectadas a Rede de Água;

\%RedeEsgoto é o Percentual de Famílias Conectadas a Rede de Esgoto;

\%ServicosUrbanos é o Percentual de Serviços Urbanos;

\%FamiliasFavelas é o Percentual de Famílias Morando em Favelas.

Esta variável é acessível apenas para os jogadores no papel de Prefeitos e é muito importante, pois a arrecadação de impostos para a prefeitura é relativa ao valor desta variável. Por exemplo, se o percentual de desenvolvimento social for de 90\%, a prefeitura arrecadará apenas $90 \%$ dos impostos a serem pagos.

Inicialmente, esta variável é diferente entre as três cidades: no município A, o percentual é de certa de $93 \%$ e nos municípios B e C é de certa de $92 \%$. 


\subsubsection{Funcionamento}

No JogoMan, os jogadores não têm acesso direto ao simulador MABS. Existe uma pessoa responsável por inserir os dados escolhidos pelos jogadores, chamada de operador. A ordem de execução das atividades do jogo é a seguinte, conforme Figura 13:

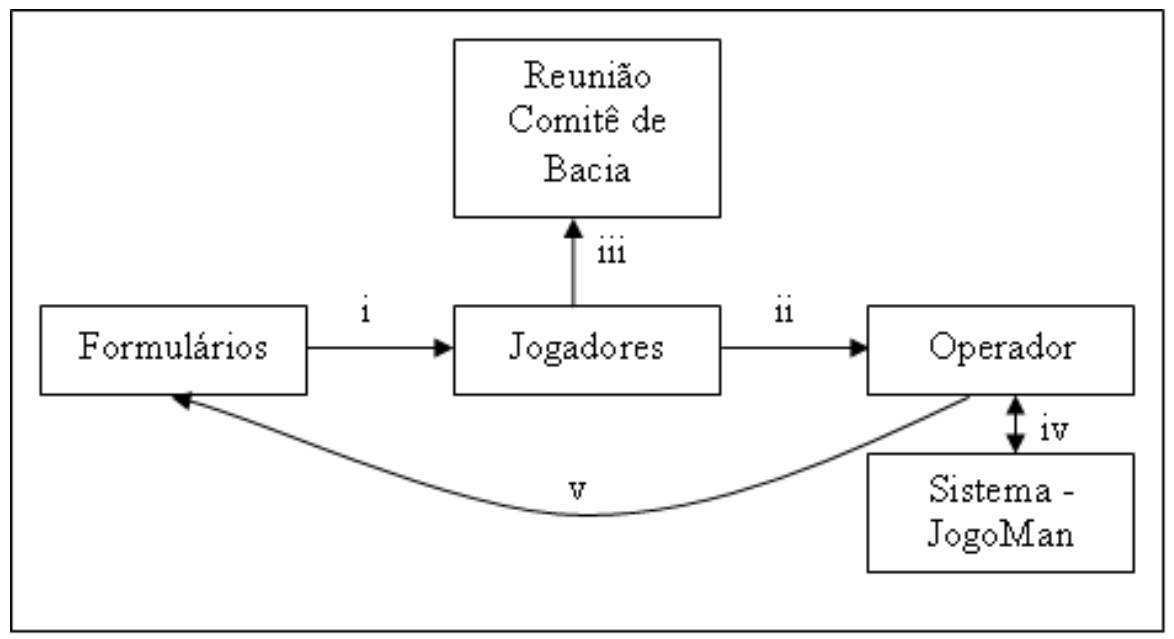

Figura 13: Funcionamento do JogoMan.

i) Em cada turno, os jogadores recebem um formulário para preencher com as ações escolhidas. Este formulário também possui informações sobre a situação do jogador na rodada. Um exemplo de formulário para o papel de Prefeito encontra-se na Figura 14.

ii) Ao final do tempo do turno, após escolherem suas ações e concluíram as negociações bilaterais, os jogadores entregam ao operador seus formulários;

iii) Os jogadores se reunem e discutem estratégias coletivas que devem ser seguidas no próximo turno de jogo, tentando simular a realidade de um "Comitê de Bacia". Estas estratégias podem ser seguidas ou não durante o próximo turno, mas ajudam a melhor entender que as ações individuais de cada jogador e como estas influenciam todo o sistema;

iv) O operador insere no sistema as ações escolhidas e estas "transformam" o ambiente;

v) Uma nova rodada é iniciada, com novas informações sobre a situação do jogador, em decorrência das ações tomadas.

As atividades i) e ii) referem-se à Fase 1 da metodologia GMABS. Já a atividade iii) refere-se à Fase 2 da metodologia GMABS. 


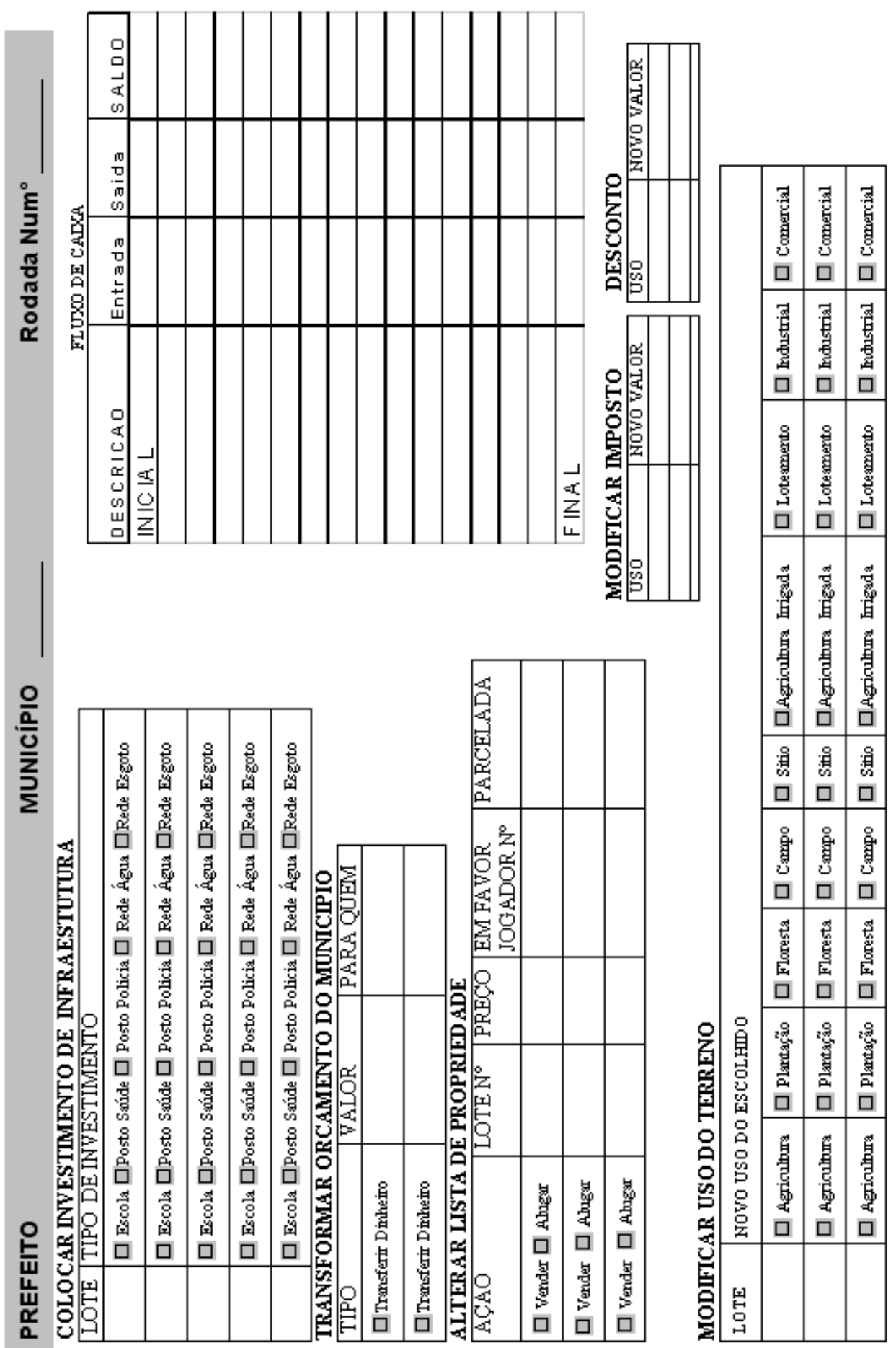

Figura 14: Formulário para o Papel de Prefeito no JogoMan.

Cada jogador escolhe suas ações individualmente. Por se tratar de um sistema interligado, as ações de cada um podem influenciar todos os outros, porque a qualidade e quantidade de água dependem do uso do solo, das infra-estruturas, da quantidade de pessoas vivendo em cada área, etc. Por exemplo, suponhase que um dos Prefeitos decida reduzir os impostos para que os Proprietários Particulares preservem suas áreas (florestas). Como resultado desta ação, vários 
Proprietários Particulares decidem manter suas áreas com florestas ou decidem investir em reflorestamento. Essa ação beneficia a qualidade e a quantidade da água. Em outro exemplo, suponha-se que um Proprietário Particular decida construir uma indústria, visando maior retorno financeiro. Tal ação pode prejudicar imensamente a qualidade das águas.

\subsubsection{Tipos de Negociação}

Na Fase 1 da metodologia GMABS existem dois tipos de ações possíveis: as individuais e as que exigem negociação, conforme já indicado na seção 2.3.2.

As ações individuais são mais simples, pois referem-se unicamente a tomada de decisão de cada jogador, referente a seus objetivos internos. No protótipo JogoMan estas ações são as seguintes:

- Mudança de uso do solo (realizada por todos os papéis);

- Alocação de famílias (realizada apenas pelo Representante dos SemTeto);

- Transferência de dinheiro (realizada pelos Prefeitos e pelo admininstrador da AguaPura).

Por exemplo, um Proprietário Particular que tem como objetivo obtenção de lucro pode escolher a ação de troca do uso do solo para Agricultura Irrigada, sem preocupação com os efeitos dessa ação sobre os demais jogadores e o ambiente e sem a necessidade de negociar com outros jogadores para executar esta ação.

As ações que exigem negociação, chamadas de Negociações Bilaterais (ver seção 2.3.2), envolvem dois jogadores. Neste protótipo, tais ações são as seguintes:

- Comprar lotes (realizada por todos os papéis);

- Alugar lotes (realizada por todos os papéis);

- Colocar infra-estrutura (realizada pelos Prefeitos e pelo Administrador da AguaPura);

- Modificar imposto (realizada pelos Prefeitos e pelo Administrador da AguaPura).

Por exemplo, caso um Prefeito deseje comprar um lote para doar ao Representante dos SemTeto, ele negocia a compra de um lote de um Proprietário 
Particular. A efetivação da compra do lote pode ou não ocorrer, dependendo dos objetivos do dono (Proprietário Particular). Para que esta ação seja concretizada, sempre haverá um processo de negociação entre os jogadores envolvidos.

Na Fase 2 da metodologia GMABS, representada no protótipo JogoMan pela "Reunião do Comitê de Bacia", todas as estratégias coletivas são consideradas negociáveis e envolvem todos os jogadores. São chamadas de Negociações Coletivas. A escolha das estratégias coletivas a serem negociadas pelos jogadores é aberta, ou seja, os jogadores decidem o que é importante para o coletivo. Exemplos de estratégias coletivas são a ampliação da rede de água potável ou a redução de impostos, que podem ser negociadas durante a Reunião do Comitê de Bacia por todos os jogadores.

Uma descrição mais detalhada das etapas para estruturação, implementação e testes do JogoMan são apresentadas no artigo (ADAMATTI et al., 2005).

\subsection{Análise dos Jogos Realizados}

Foram realizados quatro jogos-teste com o protótipo Jogoman, nos seguintes locais e datas:

1. PROCAM - Programa de Pós-Graduação em Ciência Ambiental da Universidade de São Paulo, em 29 de Outubro de 2004;

2. Faculdades Integradas Guarulhos, em 12 de Novembro de 2004;

3. Faculdade de Saúde Pública da Universidade de São Paulo, em 25 de Fevereiro de 2005;

4. Universidade de Mogi das Cruzes, em 02 de Maio de 2005.

Os jogos-teste realizados foram analisados de duas formas: mapeamento de estratégias de cada tipo de papel do jogo e questionários pré e pós-jogo, apresentados nas seções 5.3.1 e 5.3.2, respectivamente. Os jogos-teste realizados no protótipo JogoMan, bem como uma análise completa dos dados pode ser encontrada também na dissertação de mestrado de Maria Eugência S. A. Camargo (CAMARGO, 2006). Este trabalho analisa a utilização de jogos de papéis para educação ambiental, apresentando como estudo de caso o protótipo JogoMan. 


\subsubsection{Mapeamento das Estratégias dos Jogadores}

Em cada jogo-teste, os jogadores preencheram um formulário por rodada, onde descreviam suas ações. Todas as fichas utilizadas por cada jogador foram tabuladas para realização de análise de possíveis estratégias utilizadas. Estes dados encontram-se no Anexo B. Para cada papel disponível no jogo (Proprietário Particular, Administrador da AguaPura, Prefeito e Representante dos SemTeto), foi verificado se haviam ações que se repetiam em diferentes jogos-teste. A repetição de ações em diferentes jogos-teste confirma a formação autônoma de estratégias de jogo específicas para cada tipo de papel.

Verificou-se, por exemplo, que o Administrador da companhia de água, em todos os jogos-teste, colocou a infra-estrutura de Esgoto apenas em áreas onde já havia infra-estrutura de Água. Esta estratégia não faz parte das regras do jogo, mas foi utilizada por todas os jogadores que jogaram com Administrador da companhia de água.

Após encontrar diversas estratégias repetidas para cada tipo de jogador em diferentes jogos, especialistas do Projeto Negowat ${ }^{3}$ realizaram uma validação das mesmas. Esta validação verificou se as estratégias estão de acordo com o objetivo proposto para o jogo, sendo assim, estratégias válidas.

A seguir, todas as estratégias encontradas para os papéis são apresentadas.

\subsubsection{Estratégias Encontradas para os Papéis}

Os dados das fichas de cada um dos jogadores, em todas os turnos de todos os jogos-teste foram tabulados e analisados, a fim de verificar possíveis estratégias de jogo utilizadas por cada papel. Estas estratégias serão muito úteis na definição da base de conhecimento dos jogadores virtuais. As estratégias encontradas para cada um dos jogadores são as seguintes:

\section{a) Proprietários Particulares}

- (PRO01) Trocam o uso do solo para Agricultura e/ou Agricultura Irrigada, por ser um uso do solo que o investimento é baixo e tem retorno rápido, comparado aos outros usos do solo, como Indústria;

- (PRO02) Trocam o uso do solo de Floresta para Plantação, visando o ganho de supressão do corte das árvores. Depois, normalmente es-

\footnotetext{
${ }^{3}$ Raphaèle Ducrot, Pedro Jacobi, Maria Camargo e Sandra Granja.
} 
colhem colocar Agricultura/Agricultura irrigada, pelo motivo expresso no item anterior;

- (PRO03) Trocam o uso do solo para Loteamento, nas áreas próximas às áreas urbanas para comercialização junto ao Representante dos SemTeto, já que o Representante dos SemTeto sempre dá preferência por áreas próximas às áreas urbanas (ver estratégias do Representante dos SemTeto);

- (PRO04) Permutam (trocam) áreas próximas às áreas urbanas com Prefeitos e/ou Proprietários Particulares por áreas com Floresta.

\section{b) Administrador da Companhia de Água - AGUAPURA}

- (AGU01) Coloca infra-estrutura de Esgoto apenas em áreas onde já houver infra-estrutura de Água;

- (AGU02) Coloca qualquer infra-estrutura (Água ou Esgoto) primeiro em áreas onde o Representante dos SemTeto comprou ou invadiu;

- (AGU03) Negocia com Prefeitos para colocar infra-estruturas de Água e Esgoto e pede Transferência de Dinheiro;

- (AGU04) Procura comprar áreas próximas ao reservatório com o intuito de preservar a região e evitar aumentar a poluição do mesmo.

\section{c) Prefeitos}

- (PRE01) Colocam infra-estruturas de Escolas, Polícia e Hospitais apenas em áreas urbanas;

- (PRE02) As infra-estruturas de Água e Esgoto são, normalmente, colocadas pela AguaPura, e há transferência de dinheiro para compensar o investimento. Esta transferência pode ser maior que o custo inicial determinado para a infra-estrutura: por exemplo, colocar Água em uma área custa 15.000, mas os Prefeitos podem pagar até mais (17.000 20.000), por ser uma obra realizada pela AguaPura;

- (PRE03) Compram áreas de Proprietários Particulares (tentam comprar pelos menores preços) próximos a áreas urbanas para revender ao Representante dos SemTeto. Pode ser realizada a venda ou a doação para o Representante dos SemTeto, para reduzir o número de famílias "Faveladas" em seu município; 
- (PRE04) Quando já existe um número muito grande de áreas com uso do solo agrícola (Agricultura ou Agricultura Irrigada), aumentam o imposto para esse tipo de solo. Em um dos casos, por exemplo, o imposto sofreu um aumento de 5 vezes o valor inicial.

\section{d) Representante dos SemTeto}

- (SEM01) Tenta comprar áreas próximas às áreas urbanas por preços acessíveis (pode impor um limiar máximo de compra). Se não conseguir comprar as áreas, os invade;

- (SEM02) Nos jogos, normalmente os Prefeitos compraram as áreas e repassaram ao SemTeto a partir da segunda rodada, por preços mais acessíveis;

- (SEM03) Dá preferência por alocar o máximo de famílias em um mesmo lote, já comprado ou invadido. Por exemplo, se a capacidade máxima do lote é de 400 famílias, coloca 200 em uma rodada e mais 200 na próxima rodada.

\subsubsection{Questionários Aplicados aos Jogadores}

Uma das formas de avaliar jogos computacionais é a partir de questionários (BREDEMEIER; GREEnBlat, 1981; DORN, 1989). Segundo Nielsen (NIELSEN, 1993), para realizar a avaliação, sempre é necessário aplicar um questionário anterior à realização do teste (pré-questionário) e outro após (pós-questionário). O pré-questionário tem como objetivo descobrir o perfil dos jogadores, pois isso irá influenciar muito a forma que a análise dos testes será realizada. Já o pósquestionário tem como objetivo verificar o que os jogadores entenderam do sistema testado e qual foi a opinião final sobre o mesmo. Segundo os métodos de avaliação apresentados no capítulo 4, este tipo de avaliação é baseado no método Entrevistas, Questionários, Grupos de Trabalho e Feedback.

Os questionários pré e pós-jogo aplicados no JogoMan (Tabelas 5 e 6), bem como a análise das respostas fornecidas pelos jogadores são apresentadas a seguir. As principais respostas fornecidas pelos jogadores para estes questionários encontram-se no Anexo A.

\subsubsection{Análise das Respostas Fornecidas pelos Jogadores}

Pelas respostas dos questionários pré-jogo pode-se concluir que, em sua maioria, os jogadores tinham as seguintes características: 


\begin{tabular}{|l|}
\hline \hline Nome:.............................. e-mail:..................... \\
\hline $\begin{array}{l}\text { 1. Você conhece algum Jogo de papéis (RPG)? Qual? Já jogou? O que você entende } \\
\text { por jogo de papéis? }\end{array}$ \\
\hline 2. Quais são as suas expectativas para participar nessa sessão de jogo? Explique. \\
\hline 3. Na sua opinião quais são os maiores problemas da gestão dos recursos hídricos nas \\
bacias peri-urbanas? Pode especificar. \\
\hline 4. Para você quais são os fatores de sucesso de uma negociação, na área ambiental ? \\
\hline
\end{tabular}

Tabela 5: Questionário Pré-Jogo Aplicado nos Jogos-Teste do JogoMan.

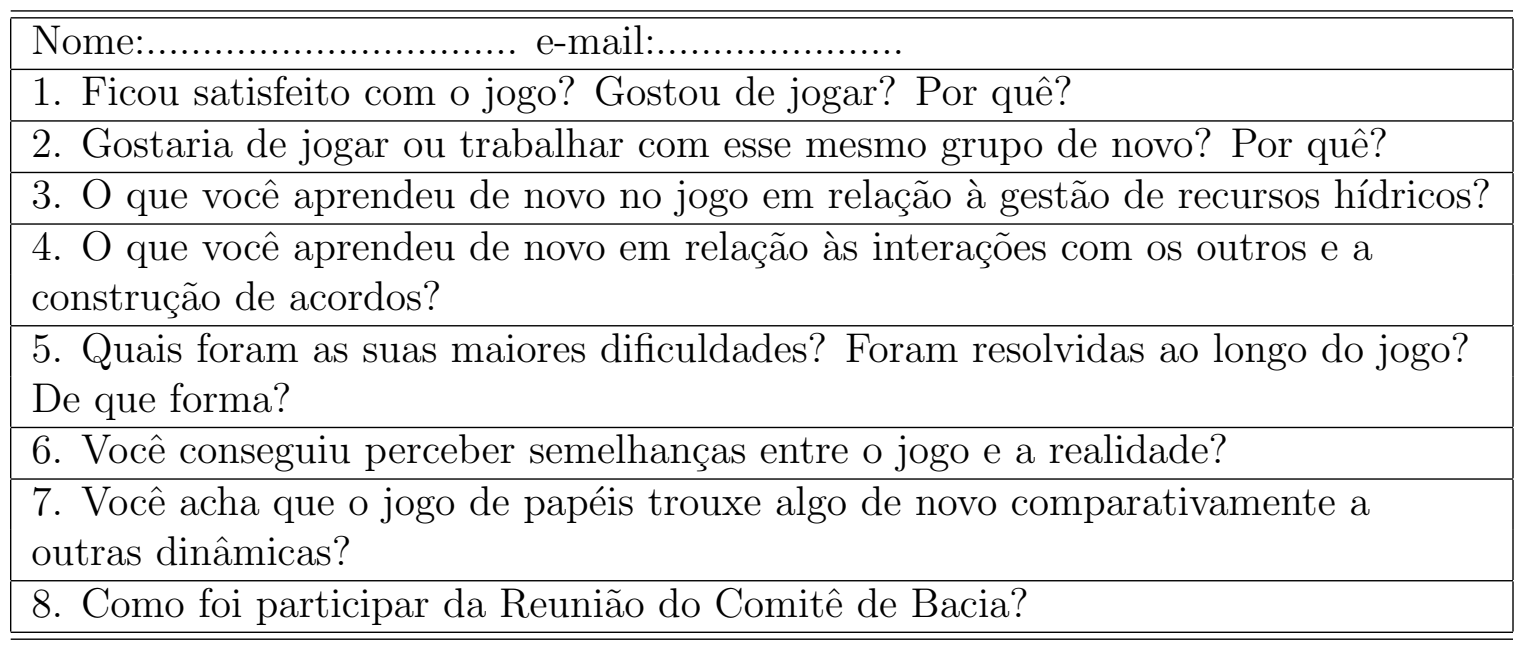

Tabela 6: Questionário Pós-Jogo Aplicado nos Jogos-Teste do JogoMan.

1. Eram inexperientes em relação ao RPG;

2. Tinham boas expectativas em relação ao jogo;

3. Conheciam a problemática da gestão de recursos hídricos, e;

4. Possuiam boas idéias e visão administrativa para que a negociação na área ambiental obtivesse sucesso.

Em relação ao primeiro aspecto, inexperiência quanto ao RPG, a grande maioria nunca havia jogado nenhum tipo de RPG. Contudo, tinham uma idéia da forma que o jogo funcionava, visto as respostas apresentadas para a questão número 2, como: "vivenciar o papel" ou "brincar e aprender ao mesmo tempo".

Como relação ao terceiro aspecto, conhecimento da problemática da gestão de recursos hídricos, foram apresentados nas respostas pontos muito importantes, como: "crescimento urbano" ou "problemas de poluição". Mesmo que nem todos fossem especialistas na área de recursos hídricos (pois alguns eram, principalmente alunos e professores da Pós-Graduação em Ciência Ambiental ou da Faculdade de Saúde Pública), as respostas demonstraram interesse na situação atual dos recursos hídricos. 
Já em relação ao quarto aspecto, foram apontados pontos significativos para uma negociação, como: "definir metas" ou "buscar o bem comum/interesses coletivos".

O questionário pós-jogo, por sua vez, verifica o que os jogadores acham do jogo, bem como o que aprenderam com o mesmo. As questões 1, 2 e 5 estavam relacionadas à opinião dos jogadores sobre o jogo. Pode-se concluir que os jogadores gostaram do jogo mas tiveram alguns problemas de entendimento, principalmente nos dois primeiros turnos dos jogo. As respostas à questão número 1 confirmam que os jogadores gostaram do jogo ("lúdico" ou "educativo"). Esta impressão se confirma também pelas respostas à questão número 2 , onde todos os jogadores afirmaram que voltariam a jogar com o mesmo grupo ("por ter sido um exercício muito gratificante").

Contudo, alguns jogadores apontaram problemas durante o jogo, relacionados ao entendimento de regras, tempo para negociação e tomada de decisão. Isto se confirma nas respostas à questão 1 ("limitação de tempo" ou "confuso/difícil de entender") e também nas respostas à questão número 5 ("falta de tempo", "tomar decisão" e "regras/objetivos").

Embora os jogadores tenham apontados vários problemas durante o jogo, todos se sentiram estimulados a jogar novamente, visto que a maioria dos problemas estava relacionado ao fato de não dominarem todas as funcionalidades que o jogo propicia. Pode-se perceber isso pelas respostas à questão número 2 ("jogar de novo seria mais produtivo agora que as regras e objetivos estão mais claros" ou "agora já entendi melhor como funciona o jogo"). Porém, as reações dos jogadores às dificuldades iniciais são normais, visto que segundo Daré e Barreteau (DARE; BARRETEAU, 2004) e Klimick (KLIMICK, 2003), o RPG não possui uma metodologia teórica para o seu desenvolvimento, e fica na dependência do públicoalvo, contexto e objetivos que se pretendem atingir e assim, para que todas as potencialidades do RPG possam ser postas em prática, é necessário conhecimento amplo do domínio que se deseja trabalhar.

As questões 3, 4, 6 e 7 eram relacionadas ao entendimento do jogo pelos jogadores. Pode-se concluir que os jogadores:

- Ampliaram seus conhecimentos na área de gestão de recursos hídricos;

- Entenderam (ou ampliaram) a importância da negociação para resolução de problemas na gestão de recursos hídricos;

- Conseguiram traçar semelhanças entre o jogo e a realidade; 
- Aprovaram o uso de RPG como ferramenta de apoio para gestão de recursos hídricos.

Em relação ao primeiro aspecto, conhecimento na área, as respostas à questão número 3 demonstram que os jogadores conseguiram ter "uma visão global da problemática". Relativo ao segundo aspecto, negociação, os jogadores perceberam quão complicado é o problema e que a gestão de recursos hídricos é complexa, a partir das respostas à questão número 4 ("díficil gerenciar os recursos para satisfação plena de todos" ou "não é fácil conciliar conflitos de interesse") e viram que a negociação é uma solução possível ("o diálogo é o melhor caminho").

Já o terceiro aspecto, semelhanças entre o jogo e a realidade, as respostas foram muito significantes, pois os jogadores levantaram alguns dos principais problemas existentes e que o jogo queria apresentar, como a pressão urbana gerada pelas invasões. Isto pode ser visto nas respostas à questão número 6 ("a água como fator essencial", "o problema das invasões" ou "o dilema desenvolvimento/conservação").

O quarto aspecto, uso do RPG, apresentou excelente aceitação dos participantes, visto que estes apontaram para as principais características do RPG: socialização e interatividade de forma lúdica. Isso se confirma nas respostas à questão número 7 ("cenário dinâmico", "debate em grupo", ou "experiência lúdica").

A questão 8 está relacionada à Reunião do Comitê de Bacia. A idéia de simular uma reunião este tipo no jogo se mostrou interessante aos jogadores, pois puderam entender como funciona a formação de estratégias coletivas. Isso pode ser visto em várias respostas ("Senti-me instigado a defender meus interesses e ao mesmo tempo direcionar a discussão para uma solução conjunta”).

\subsection{Considerações Finais}

Este capítulo apresentou o protótipo JogoMan, desenvolvido utilizando a metodologia GMABS para a área de Gestão de Recursos Naturais.

Inicialmente, foram apresentados os objetivos e papéis do jogo, bem como o seu funcionamento. Em seguida, foram apresentados os jogos-teste realizados, onde verificou-se a criação de estratégias executadas repetidamente por cada tipo de jogador (seção 5.3.1). Nestes jogos-teste foram aplicados questionários, que apresentaram respostas bastante positivas sobre o jogo (seção 5.3.2). 
Sendo este protótipo uma instância de um sistema de apoio a decisão em grupo (SAD-G) e visando a educação ambiental, ele deve auxiliar no entendimento da problemática envolvida na gestão de recursos hídricos e como o processo de negociação para este domínio pode acontecer de uma melhor forma. Pelos jogos-teste realizados com os grupos e a partir das respostas dos jogadores nos questionários pré e pós jogo, pode-se verificar que o protótipo atingiu seus objetivos.

Uma vez desenvolvido este protótipo, o passo seguinte na metodologia adotada foi o de prover uma arquitetura que pudesse contemplar jogadores virtuais, como mostrado a seguir. 


\section{Arquitetura ViP-GMABS}

Este capítulo tem por objetivo a definição de uma arquitetura genérica, onde jogadores virtuais possam ser integrados na metodologia GMABS. Também é necessário definir uma arquitetura cognitiva para os jogadores virtuais, de modo que estes possuam tomada de decisão parecida a dos jogadores reais. A definição desta arquitetura refere-se a atividade número 3 da metodologia adotada, descrita na seção 1.3.

A seção 6.1 apresenta qual foi a motivação para desenvolver a arquitetura genérica e as seções 6.2 e 6.3 apresentam, respectivamente, a arquitetura genérica e a arquitetura cognitiva dos jogadores virtuais. As considerações finais deste capítulo são então apresentadas na seção 6.4.

\subsection{Motivação}

A proposta desta tese é integrar jogadores virtuais na metodologia GMABS, sendo tal extensão denominada ViP-GMABS (Virtual Players in Games and Multi-Agent-Based Simulation).

O RPG é um jogo com muitas vantagens e baseia-se na idéia que cada jogador assumirá um papel e tomará decisões a partir das regras estabelecidas pelo jogo. Entretanto, um fator muito importante no RPG é o aspecto socializante, a partir da interação dos jogadores, fazendo com que os mesmos aprendam uns com os outros. E é esse fator que pode ser um dos grandes problemas do RPG: se por um lado o processo de negociação entre os jogadores é importante para que haja veracidade do mesmo em relação à realidade, por outro lado existe a dificuldade de realizar o jogo com um número grande de jogadores.

Um dos fatores que mais influenciaram na escolha deste tema de pesquisa foi a experiência de não ter o número de jogadores necessários para a realização de um jogo. Quando foram realizados os jogos-teste no protótipo JogoMan, que necessita de 14 jogadores, percebeu-se a necessidade da existência de algum tipo 
de ferramenta computacional para esta finalidade. A razão é simples: agendar com 14 pessoas para estarem em um mesmo local por um período completo do dia (manhã/tarde/noite) para realização dos testes é uma tarefa complicada.

Além da necessidade do número mínimo de jogadores, outra tarefa que pode ser realizada por jogadores virtuais é a de forçar determinadas situações no jogo, como forma de mostrar outras possíveis escolhas que podem ser feitas, visando apresentar novas "visões" do jogo.

Desta forma, a idéia de integração de jogadores virtuais na metodologia GMABS, de forma a poder substituir os jogadores reais ou forçar determinadas situações, de maneira verossímel, é um trabalho altamente desafiador, porque a integração já pode ser considerada complexa. Adicionalmente, deve-se ainda representar a tomada de decisão destes jogadores.

Na definição da arquitetura genérica e dos jogadores virtuais, deve-se determinar seus elementos e os requisitos necessários para suas interações, sempre apresentando os elementos de forma abstrata para que os mesmos sejam independentes de domínio e de ferramentas.

\subsection{Arquitetura Genérica}

Os elementos necessários na metodologia GMABS são apresentados na Figura 15, onde o sistema computacional é representado pelo simulador MABS e o elemento RPG representa os jogadores reais que participam do jogo.

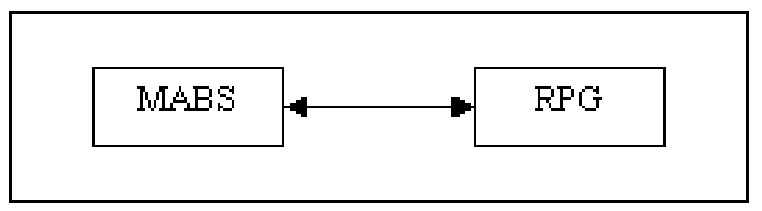

Figura 15: Elementos da Metodologia GMABS.

Para a inserção de jogadores virtuais no RPG, é necessário expandir o RPG em dois sub-elementos, os jogadores reais e os jogadores virtuais, conforme mostra a Figura 16.

Para que o simulador MABS não seja alterado com a inserção de jogadores virtuais no RPG, se faz necessária uma camada de comunicação intermediária comum entre os dois elementos, já que deseja-se que o simulador MABS não faça diferenciação entre os jogadores reais e os virtuais. Desta forma, com a camada de comunicação, a troca de informações entre os dois elementos, visto do ponto 


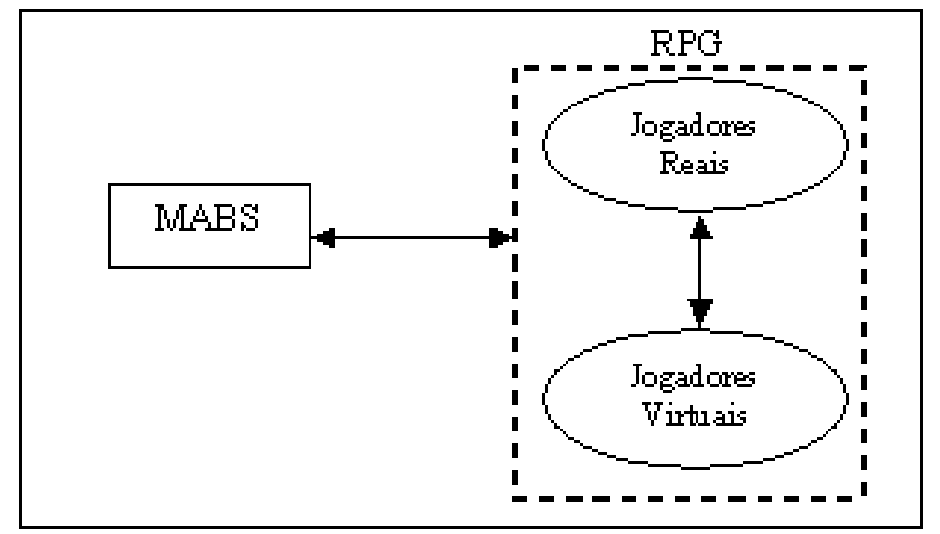

Figura 16: Elementos da Arquitetura ViP-GMABS.

de vista do simulador MABS, é igual à troca realizada quando da não existência de jogadores virtuais, conforme a Figura 15. Esta camanda também serve como meio de comunicação entre os jogadores reais e virtuais, pois durante o processo de tomada de decisão, estes podem trocar informações. Assim, os elementos da arquitetura ViP-GMABS são apresentados na Figura 17.

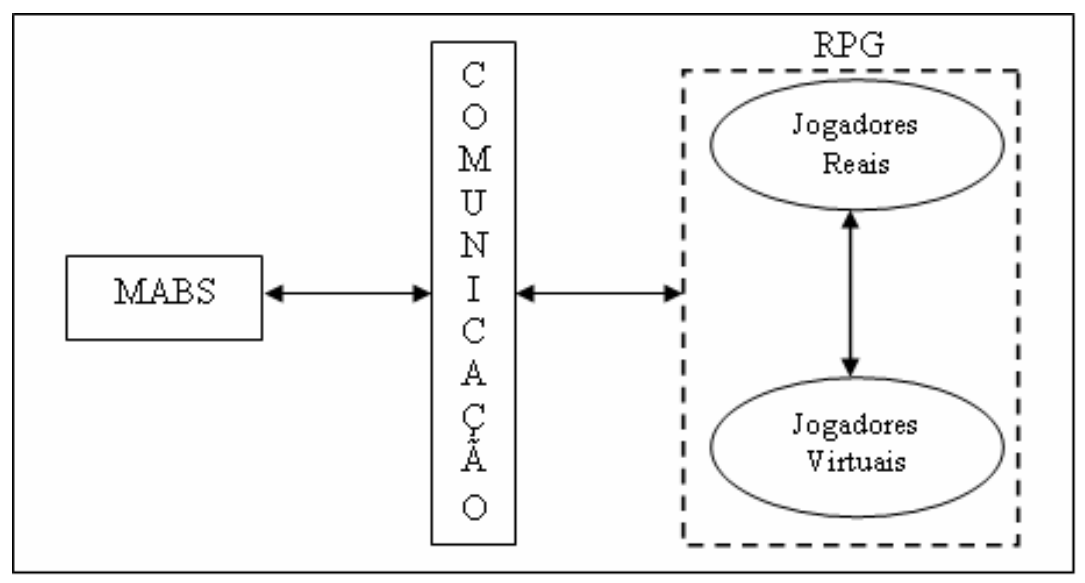

Figura 17: Arquitetura Genérica ViP-GMABS.

Com a definição da arquitetura desta maneira, espera-se atingir os seguintes objetivos:

- Independência de domínio;

- Independência de ferramenta.

Deste modo, a metodologia GMABS poderá ser implementada para qualquer área de conhecimento, não apenas na gestão de recursos naturais, que será o foco dos estudos de caso deste trabalho. Deseja-se também que esta possa ser utilizada com qualquer ferramenta de simulação multiagentes existente, e não apenas para o simulador Cormas, que é a ferramenta utilizada nos estudos de 
caso deste trabalho, bem como para qualquer ferramenta que possa estruturar a arquitetura dos jogadores virtuais.

Os requisitos para que haja a comunicação entre os elementos MABS e RPG são os seguintes:

1. O simulador MABS deve fornecer, em algum formato padrão de troca de informações (por exemplo ASCII ou XML), os dados informativos do sistema, como situação atual do cenário e dos jogadores;

2. A camada de comunicação deve receber as informações do simulador MABS e repassá-las de forma integral e uniforme para os jogadores reais e virtuais. Também deve retornar as ações escolhidas pelos jogadores ao simulador, a fim de executá-las;

3. Os jogadores virtuais devem receber as informações da camada de comunicação e serem capazes de manipulá-las, e se necessário comunicar-se com os outros jogadores (reais e/ou virtuais), a fim de obter novas informações sobre o cenário e/ou jogadores que julgarem importantes.

Os requisitos definidos para esta arquitetura não especificam, em primeira instância, o desempenho do sistema. O foco está na utilização da metodologia GMABS, independente de domínios e de ferramentas. A ausência de especificação de desempenho da arquitetura vale-se do fato que a comunicação entre os jogadores, bem como a tomada de decisão e processamento das ações escolhidas por estes, podem efetuar-se em um tempo maior, conforme o passo número 2 da metodologia GMABS (ver seção 2.3.2). É claro que, as ações descritas acima não podem demorar um tempo longo demais. Entretanto, como não se trata de um sistema de tempo real, não há preocupação em especificar nesta arquitetura critérios rígidos de desempenho do sistema.

\subsection{Arquitetura Cognitiva dos Jogadores Virtu- ais}

Para alcançar o objetivo do trabalho, é necessário ainda definir uma arquitetura cognitiva para os jogadores virtuais. Esta arquitetura cognitiva deve atender aos requisitos citados anteriormente, que são de receber novas informações e manipulá-las, a partir de objetivos internos pré-definidos, bem como comunicar-se com os outros jogadores, sejam reais ou virtuais, de forma a obter novas informações sobre o cenário. Também devem retornar à camada de comunicação, e 
conseqüentemente ao simulador MABS, a(s) ação(ões) escolhidas pelos jogadores no ciclo de simulação.

Os jogadores virtuais devem definir a priori os objetivos e estratégias a serem tomadas no domínio do problema. Além de receber informações sobre o cenário e os outros jogadores, devem decidir que estratégia tomar, ou seja, devem possuir tomada de decisão.

Entende-se por objetivos as metas que os jogadores desejam alcançar durante o jogo. As estratégias são as formas de alcançar estes objetivos. A tomada de decisão é a escolha da melhor estratégia em um determinado cenário, segundo os objetivos e estratégias definidos. Por exemplo, considere que um jogador assuma o papel de industrial em um jogo, e seu objetivo seja obter dinheiro. Ele pode alcançá-lo através de duas estratégias distintas: ampliar sua(s) empresa(s) ou dobrar o turno de trabalho de seus funcionários. A tomada de decisão da melhor estratégia dependerá, por exemplo, da situação econômica do país.

Desta maneira, a arquitetura dos jogadores virtuais deve possuir os elementos apresentados na Figura 18.

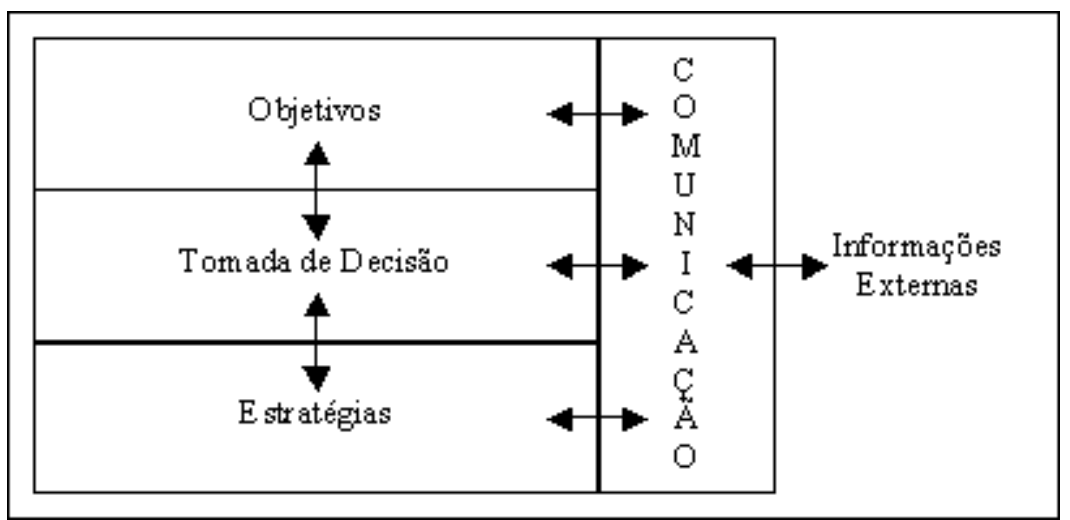

Figura 18: Arquitetura Cognitiva dos Jogadores Virtuais.

A camada de comunicação interna de cada jogador virtual, apresentada na Figura 18, deve ser compatível com a camada de comunicação da arquitetura genérica, apresentada na Figura 17, para que a integração entre as duas arquiteturas seja possível. Assim, a configuração interna da arquitetura de cada jogador virtual fica independente das ferramentas que forem utilizadas para a sua implementação.

A Figura 18 também apresenta setas de comunicação entre todos os elementos da arquitetura. Isso implica que todos os elementos podem trocar informações e também podem buscar informações externas, em outros agentes ou no ambiente, a fim de escolher a melhor estratégia a partir dos objetivos definidos. 
Desta forma, os requisitos da arquitetura cognitiva dos jogadores virtuais são:

1. Definição de objetivos e estratégias a priori;

2. Mecanismo para tomada de decisão;

3. Camada de comunicação interna compatível com a camada de comunicação da arquitetura genérica, viabilizando a comunicação entre os jogadores virtuais e reais;

4. Compatibilidade entre todos os elementos da arquitetura (Objetivos, Estratégias, Tomada de Decisão e Comunicação), visando a troca de informações entre os mesmos e com o ambiente.

\subsection{Considerações Finais}

Este capítulo apresentou a definição da arquitetura genérica ViP-GMABS para inserção de jogadores virtuais na metodologia GMABS, a partir dos elementos e dos requisitos necessários para seu funcionamento. Também foi apresentada a arquitetura cognitiva dos jogadores virtuais, que deve ser integrada com a arquitetura genérica.

A arquitetura cognitiva dos jogadores virtuais deve servir para que estes exibam um comportamento semelhante ao dos jogadores humanos. Para isto, devem-se definir seus perfis de comportamento, como mostrado a seguir. 


\section{Perfis para os Jogadores Virtuais}

Este capítulo apresenta a forma de estruturação dos objetivos e das estratégias para os jogadores virtuais, baseada em perfis comportamentais. A definição destes perfis é baseada no mapeamento das estratégias dos jogadores nos jogos-teste do protótipo JogoMan, apresentadas na seção 5.3 .1 e refere-se à atividade número 4 da metodologia adotada, descrita na seção 1.3. Os perfis são descritos na seção 7.1 e alguns comentários pertinentes são apresentados na seção 7.2. As considerações finais do capítulo encontram-se na seção 7.3.

\subsection{Perfis Comportamentais}

Quando as estratégias dos jogadores reais que participaram dos jogos-teste do protótipo JogoMan foram mapeadas, conforme apresentado na seção 5.3.1, podese perceber que para um mesmo papel, como Proprietário Particular, haviam interesses diversos, alguns com maior preocupação econômica, outros maior preocupação ambiental ou social. Baseado nestes interesses, foi possível definir perfis comportamentais diferentes para cada papel do jogo.

Além das estratégias encontradas nas fichas de escolha dos jogadores nos jogos-teste do protótipo JogoMan, também foram incluídas algumas estratégias "desejadas" para os jogadores, ou seja, seqüências de ações que podem apresentar novas visões de jogo aos outros jogadores.

Todos os perfis comportamentais definidos foram validados por um grupo de especialistas do Projeto Negowat ${ }^{1}$ para verificar a corretude das estratégias definidas.

Os dados completos obtidos dos jogos-teste no protótipo JogoMan, que deram origem aos perfis comportamentais, encontram-se no Anexo B. Também neste anexo, encontra-se uma explicação, baseada nos dados, de como cada estratégia

\footnotetext{
${ }^{1}$ Raphaèle Ducrot, Pedro Jacobi, Maria Camargo e Sandra Granja.
} 
foi definida para os perfis comportamentais.

Foram definidos 9 perfis diferentes, envolvendo os quatro diferentes papéis disponíveis no jogo: dois para o Proprietário Particular, dois para o administrador da AguaPura, três para o Prefeito e dois para o Representante dos SemTeto. A seguir, tais perfis comportamentais definidos são apresentados, e para cada um deles apresentam-se o objetivo e as diversas estratégias relacionadas ao perfil. Para cada uma das estratégias apresentadas para os perfis, é realizada uma correlação com as estratégias definidas na seção 5.3.1, a partir de uma sigla. Estas siglas identificam cada uma das estratégias mapeadas no protótipo JogoMan e sua utilização na definição dos perfis. Por exemplo, a primeira estratégia mapeada para os Proprietários Particulares foi identificada pela sigla PRO01, utilizada no perfil comportamental dos Proprietários Particulares com interesse econômico. Já as siglas DESXX, referem-se a estratégias desejadas e incluídas nos perfis comportamentais, sem correlação com o mapeamento anteriormente realizado.

\subsubsection{Proprietários Particulares}

\subsubsection{Perfil Comportamental: Interesse Econômico}

Objetivo: Todas as suas ações visam retorno financeiro (lucro). Suas ações não levam em conta a situação de poluição do reservatório, nem os índices sociais dos municípios.

Estratégias:

- (PRO03) Se tiver áreas próximas às áreas urbanas, trocar o uso do solo para Loteamento, para comercialização junto ao Representante dos SemTeto, já que o Representante dos SemTeto sempre dá preferência por áreas próximas às áreas urbanas.

- (DES01) Tentar vender áreas com Loteamento ao Representante dos SemTeto. O valor de oferta mínimo é o retorno do investimento realizado (implantação do Loteamento);

- (PRO01) Se uso do solo atual não for Floresta, trocar o uso do solo para Agricultura e/ou Agricultura Irrigada, por ser um uso do solo cujo investimento é baixo e tem retorno rápido, comparado aos outros usos do solo, como Indústria; 
- (PRO02) Se uso do solo atual for Floresta, trocar para Plantação, visando o ganho de supressão do corte das árvores. Depois, utilizar a estratégia anterior, transformando em Agricultura/Agricultura Irrigada;

\subsubsection{Perfil Comportamental: Interesse Ambientalista}

Objetivo: Todas as suas ações procuram melhorar a situação ambiental da região. Há uma preocupação muito grande com a situação de poluição do reservatório.

Estratégias:

- (PRO04) Se tiver áreas próximas às áreas urbanas, permutar (trocar) com Prefeitos e/ou Proprietários Particulares por áreas com Floresta mais afastadas do perímetro urbano;

- (DES02) Tenta comprar áreas próximas ao reservatório para preservação;

- (DES03) Se tiver áreas com florestas, não realizar a mudança de uso do solo, nem vender a nenhum outro jogador.

\subsubsection{Administrador da Companhia de Água (AGUAPURA)}

\subsubsection{Perfil Comportamental: Interesse Racional}

Objetivo: Todas as suas ações procuram melhorar a rede de Água e Esgoto de forma racional e lucrativa financeiramente. Tenta otimizar as áreas de implantação de infra-estrutura, bem como receber algum retorno financeiro dos Prefeitos pela prestação deste serviço.

Estratégias:

- (AGU01) Colocar infra-estrutura de Esgoto apenas em áreas onde já houver infra-estrutura de Água;

- (AGU02) Colocar qualquer infra-estrutura (Água ou Esgoto) primeiro em áreas onde o Representante dos SemTeto comprou ou invadiu;

- (AGU03) Negociar com Prefeitos para colocar infra-estrutura de Água e Esgoto e pedir Transferência de Dinheiro, visando lucro sobre o custo mínimo da infra-estrutura; 
- (DES03) Colocar infra-estrutura de Água e Esgoto até chegar à Estação de Água (ETA) e à Estação de Esgoto (ETE). É importante salientar que se o Esgoto for coletado mas não for tratado (não houver ligação com a ETE), os índices de poluição global não são muito reduzidos.

\subsubsection{Perfil Comportamental: Interesse Protetor-Ambientalista}

Objetivo: Todas as suas ações procuram melhorar a situação ambiental da região, colocando infra-estrutura de Água e Esgoto em áreas onde pessoas estejam morando e fazendo a ligação com a Estação de Tratamento de Água (ETA) e com a Estação de Tratamento de Esgoto (ETE).

Estratégias:

- (AGU04) Procurar comprar áreas próximos ao reservatório com o intuito de preservar a região e evitar aumentar a poluição do mesmo.

- (AGU01) Colocar infra-estrutura de Esgoto apenas em áreas onde já houver infra-estrutura de Água;

- (AGU02) Colocar qualquer infra-estrutura (Água ou Esgoto) primeiro em áreas onde o Representante dos SemTeto comprou ou invadiu;

- (DES03) Colocar infra-estrutura de Água e Esgoto até chegar à ETA e à ETE.

\subsubsection{Prefeitos}

\subsubsection{Perfil Comportamental: Interesse Social}

Objetivo: Todas as suas ações procuram melhorar a qualidade de vida dos habitantes do município, e tenta diminuir a quantidade de pessoas morando em situação precárias (favelas).

Estratégias:

- (PRE01) Colocar infra-estrutura de Escolas, Polícia e Hospitais apenas em áreas urbanas e/ou habitadas (áreas urbanas ou favelas);

- (PRE03) Comprar áreas de Proprietários Particulares (tentam comprar pelos menores preços) próximos a áreas urbanas para revender ao Representante dos SemTeto. Pode ser realizada a venda ou a doação para o Representante, para reduzir o número de famílias "Faveladas" em seu município; 
- (DES04) Colocar infra-estrutura de Água e Esgoto em áreas habitadas (áreas urbanas ou favelas).

\subsubsection{Perfil Comportamental: Interesse Ambientalista}

Objetivo: Todas as suas ações procuram melhorar a situação ambiental da região. Há uma preocupação muito grande com a situação de poluição do reservatório, e o efeito das mudanças de uso do solo mais poluentes, bem como com a colocação de infra-estrutura de Água e Esgoto.

Estratégias:

- (PRE04) Quando já houver um número muito grande de áreas com uso do solo agrícola (Agricultura ou Agricultura Irrigada), aumentar o imposto para esse tipo de solo;

- (DES05) Reduzir imposto sobre áreas com Florestas, com intuito de aumentar o número de proprietários que deixam suas áreas com este uso do solo;

- (DES04) Colocar infra-estrutura de Água e Esgoto em áreas habitadas (áreas urbanas ou favelas).

\subsubsection{Perfil Comportamental: Interesse Econômico}

Objetivo: Todas as ações têm preocupação com a qualidade de vida dos habitantes do município, porém, só executa as ações se tiver dinheiro em caixa para isso.

Estratégias: Segue as estratégias do Perfil "Interesse Social", porém só executa as atividades se tiver dinheiro na poupança, evitando a todo custo fica com saldo negativo.

\subsubsection{Representante dos SemTeto}

\subsubsection{Perfil Comportamental: Interesse Econômico}

Objetivo: Todas as suas ações visam retorno financeiro (lucro). Suas ações não levam em conta a situação de poluição do reservatório, nem os índices sociais dos municípios.

Estratégias: 
- (SEM01) Tentar comprar áreas por preços baixos (a partir de um limiar), independente da região ou da infra-estrutura da área. Se não for possível comprar, invadir áreas próximas às regiões urbanas;

- (SEM03) Alocar máximo de famílias em um mesmo lote, já comprado ou invadido. Por exemplo, se a capacidade máxima do lote é de 400 famílias, coloca 200 em uma rodada e mais 200 na próxima rodada.

\subsubsection{Perfil Comportamental: Interesse Social}

Objetivo: Todas as suas ações procuram alojar os moradores sem teto em áreas com melhor situação (localização próxima às áreas urbanas e com infraestrutura).

Estratégias:

- (SEM02) Negociar com Prefeitos a compra ou doação de áreas;

- (SEM01) Comprar áreas próximas à região urbana, de preferência com uso do solo Loteamento, para que as famílias alocadas estejam em áreas com melhor situação. Se não conseguir comprar os lotes, os invade;

- (SEM03) Alocar o máximo de famílias em um mesmo lote, já comprado ou invadido. Por exemplo, se a capacidade máxima do lote é de 400 famílias, coloca 200 em uma rodada e mais 200 na próxima rodada.

\subsection{Comentários sobre os Perfis}

Os perfis comportamentais para os jogadores virtuais definidos neste capítulo foram baseados na análise dos jogos-teste do protótipo JogoMan, apresentados no capítulo 5. A análise das ações dos jogadores nestes jogos-teste foi realizada de forma isolada (ação a ação) para definição dos perfis comportamentais. Contudo, alguns jogadores comportaram-se de forma muito parecida aos perfis comportamentais definidos, executando algumas ações em seqüência durante as rodadas de jogo, conforme as estratégias definidas para os perfis. 


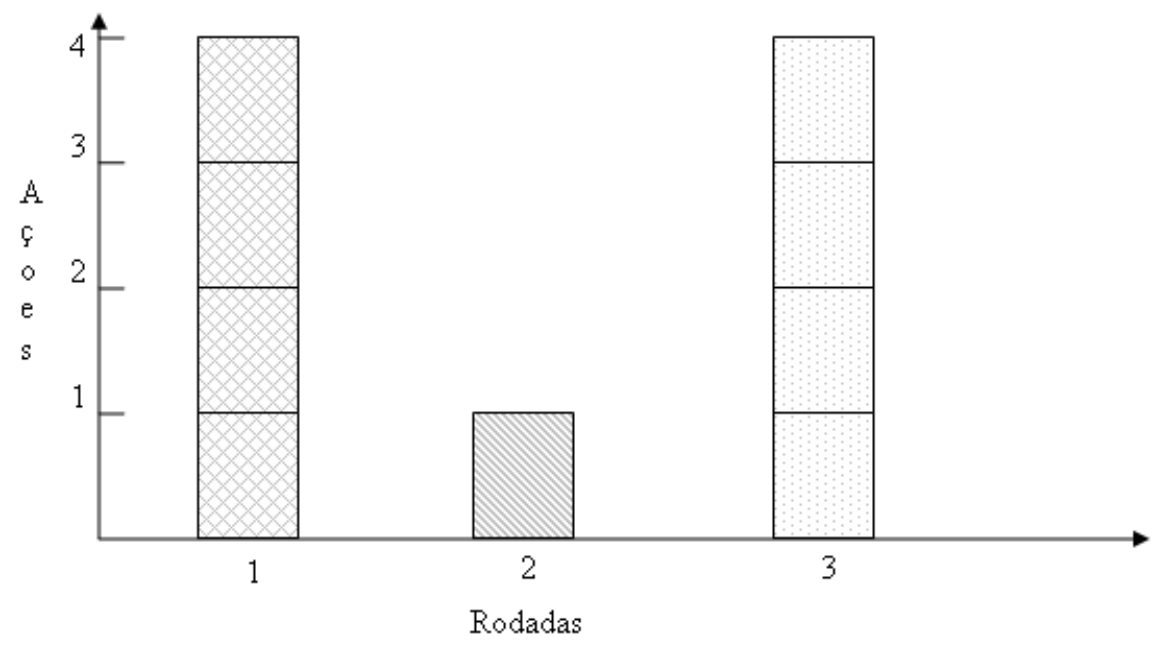

Mudança de uso do solo para Plantação (Estratégia 4)

Venda de área para outro proprietário particular

Mudança de uso do solo para Agricultura Irrigada (Estratégia 3)

Figura 19: Proprietário Particular 4 - Jogo 2 - Faculdade Integrada de Guarulhos - Utiliza um Perfil Econômico.
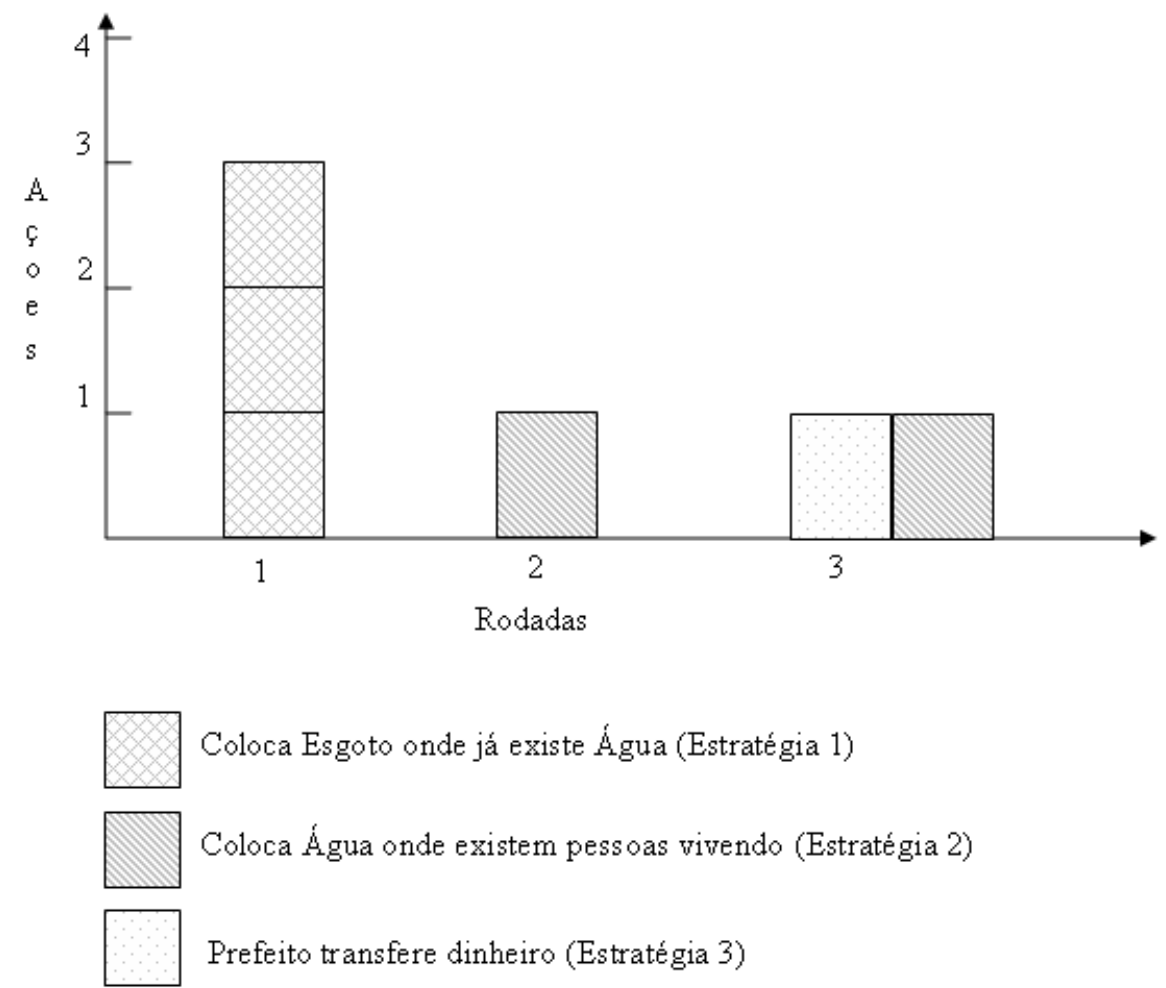

Figura 20: Administrador AGUAPURA - Jogo 2 - Faculdade Integrada de Guarulhos - Utiliza um Perfil Racional.

Nas Figuras 19, 20, 21 e 22 são apresentadas algumas destas seqüências de ações escolhidas por alguns jogadores, durante as rodadas do jogo, para cada um dos papéis do jogo. Por exemplo, a Figura 20 apresenta a seqüência de ações 


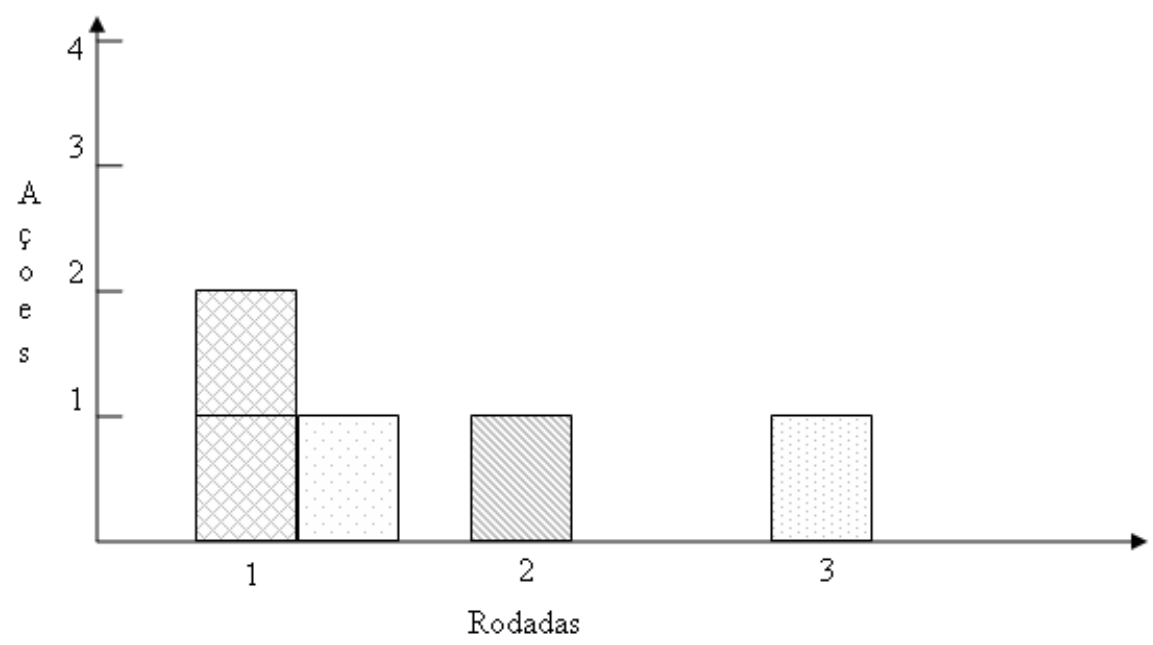

Coloca infra-estruturas de escola, polícia, hospital (Estratégia 1)

Modifica valor do imposto em áreas agrícolas (Estratégia 1)

Coloca infra-estrutura de Agua e Esgoto onde existem pessoas vivendo

(Estratégia 3)

Figura 21: Prefeito C - Jogo 3 - Faculdade de Saúde Pública da USP - Utiliza um Perfil Ambientalista.

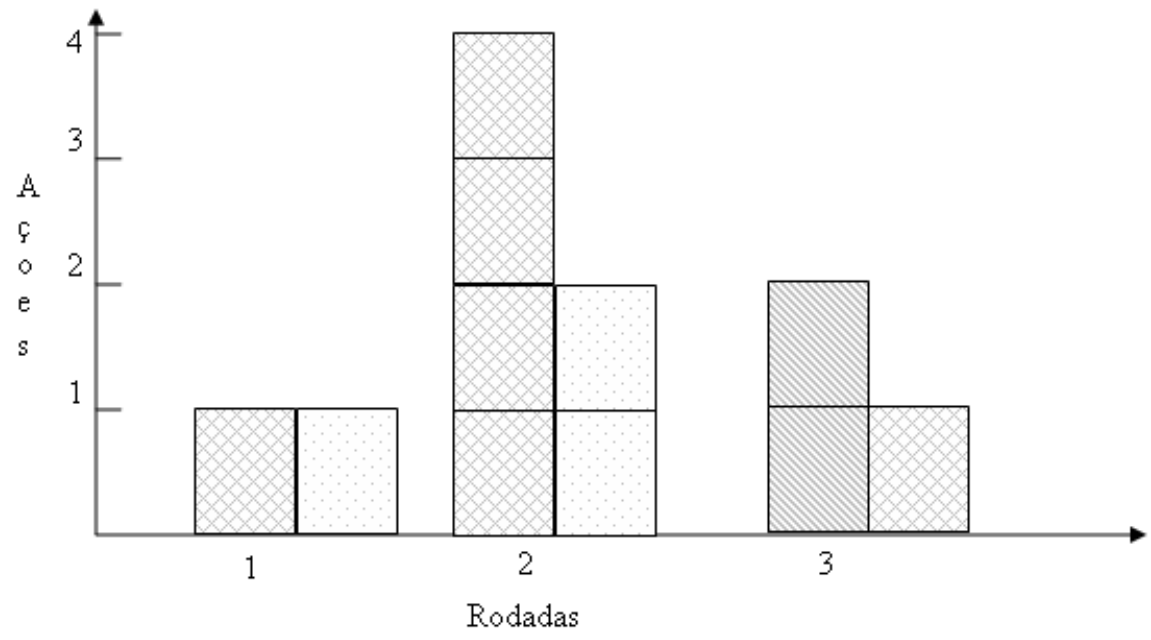

Aloca famílias em áreas próximas a áreas urbanas (Estratégia 2) e como número máximo possível para alocação (Estratégia 3)

Invade áreas próximas a áreas urbanas (Estratégia 2) e como número máximo possivel para alocação (Estratégia 3)

Negocia a compra de áreas com Prefeitos (Estratégia 1)

Figura 22: Representante dos SemTeto - Jogo 4 - Universidade de Mogi das Cruzes - Utiliza um Perfil Social.

do jogador no papel de Administrador da AguaPura no jogo-teste 2, realizado na Faculdade Integrada de Guarulhos. Este jogador utiliza um perfil comporta- 
mental com interesse racional, pois executa as três primeiras estratégias definidas para este perfil:

- Estratégia 1: colocou três infra-estruturas de esgoto apenas onde já havia infra-estruturas de água;

- Estratégia 2: colocou uma infra-estrutura de água onde haviam pessoas vivendo, no caso, novas famílias que invadiram lotes;

- Estratégia 3: negociou com Prefeito B para colocar infra-estrutura de água e esgoto e este Prefeito transferiu dinheiro ao Administrador da AguaPura para prestar este serviço.

Uma das especialistas do projeto, a cientista social Sandra Granja, questionou se os perfis comportamentais definidos não eram "caricaturados", ou seja, se as estratégias definidas não eram demasiadamente boas ou ruins para o meio-ambiente ou pessoas ou economia. Por exemplo, um Prefeito com perfil comportamental de interesse social tem apenas preocupação com a qualidade de vida dos habitantes de seu município, e não tem definidas estratégias de preservação do meio ambiente. Já um Prefeito com interesse ambientalista tem suas ações apenas voltadas para os problemas do meio-ambiente e não tem definidas estratégias para solução dos problemas sociais. Na realidade, um Prefeito deve tentar agir sobre todos esses aspectos, buscando um equilíbrio global.

Contudo, esta forma "caricaturada" para os perfis comportamentais foi a maneira encontrada para ressaltar em cada um dos papéis do jogo alguns aspectos relevantes. No caso do papel de Prefeito, por exemplo, definir um perfil comportamental com interesse social, onde o jogador virtual que utilizar este perfil apenas tenha preocupação com o aspecto social de sua cidade, fará com que os outros jogadores percebam, a partir de suas estratégias, os objetivos propostos para este perfil de forma clara e assim, possam ter outras visões do jogo, podendo seguir ou não o objetivo deste perfil.

\subsection{Considerações Finais}

Este capítulo apresentou os perfis comportamentais definidos, baseados no mapeamento das estratégias nos jogos-teste do protótipo JogoMan. Estes perfis serão utilizados para definir a base de conhecimento dos jogadores virtuais, apresentada na seção 8.3. 
Um aspecto levantado pelos especialistas que avaliaram os perfis comportamentais foi a forma que estes perfis foram definidos. Para que novas visões de jogo possam ser verificadas pelos outros jogadores, foi escolhido "forçar" algumas situações. Assim, os objetivos definidos para cada perfil comportamental podem ser identificados pelos outros jogadores de forma clara.

No próximo capítulo, descreve-se o protótipo ViP-JogoMan, onde tais perfis comportamentais forma efetivamente implementados. 


\section{Protótipo ViP-JogoMan}

Este capítulo apresenta o segundo protótipo desenvolvido neste trabalho, utilizado para executar as atividades 5, 6 e 7 da metodologia descrita na seção 1.3. Este protótipo, denominado ViP-JogoMan (Virtual Players in JogoMan), é uma instância da arquitetura ViP-GMABS, definida no capítulo 6.

Na seção 8.1, a visão geral do protótipo é apresentada. A descrição da ferramenta MABS e da implementação da arquitetura cognitiva dos jogadores virtuais são descritas, respectivamente, nas seções 8.2 e 8.3. A interface humanocomputador é descrita na seção 8.4 e a seção 8.5 mostra os protocolos de comunicação utilizados. Finalmente, as considerações finais do capítulo encontram-se na seção 8.6.

\subsection{Visão Geral}

O protótipo ViP-JogoMan utiliza os mesmos papéis, regras e variáveis definidos para o protótipo JogoMan, descrito no capítulo 5. O protótipo também é um SAD-G e visa auxiliar no processo de negociação na gestão de recursos hídricos.

Contudo, diferentemente do protótipo JogoMan, onde a única ferramenta computacional é o simulador Cormas, no protótipo ViP-JogoMan são necessárias outras ferramentas que atendam os requisitos estabelecidos para a arquitetura ViP-GMABS. Além disso, deseja-se que este protótipo possa ser executado via Web, de maneira que os jogadores tenham acesso ao jogo de forma remota. Para os três elementos (MABS, Comunicação e RPG) as ferramentas escolhidas foram as seguintes, conforme mostra a Figura 23:

- Ferramenta MABS: o simulador Cormas (CORMAS, 2006) foi utilizado na implementação do protótipo do JogoMan e assim, pode-se reaproveitar todas as funcionalidades já implementadas para ele. O Cormas também possui funções específicas para retorno de dados em diferentes formatos, como ASCII, e este aspecto era um dos pré-requisitos definidos na arquitetura 


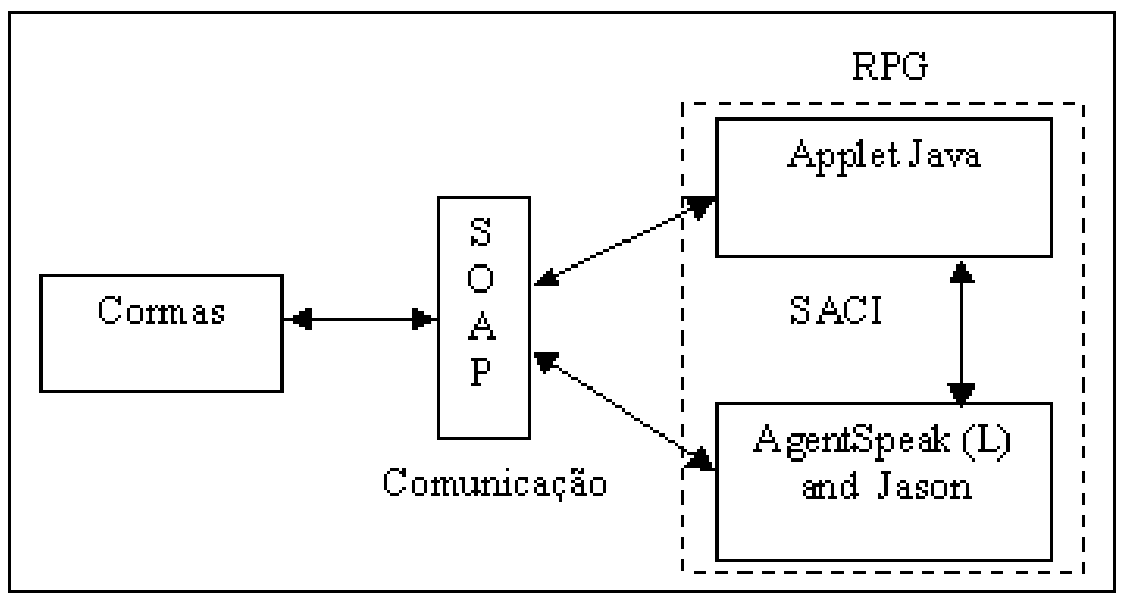

Figura 23: Ferramentas Escolhidas.

abstrata definida no capítulo 6 .

- $R P G$ :

- Jogadores Virtuais: escolheu-se a arquitetura BDI (Beliefs, Desires and Intentions), pois esta arquitetura possui uma lógica definida a partir da linguagem AgentSpeak(L) (RAO, 1996) e um interpretador chamado Jason (BORDINI; HUBNER, 2004). Este interpretador permite que cada passo da lógica desenvolvida possa ser visualizado e analisado individualmente, e permite que haja comunicação entre os jogadores virtuais e o ambiente, ou seja, com os outros jogadores virtuais e/ou reais e com o simulador MABS, requisitos estes definidos para a arquitetura cognitiva (seção 6.3).

- Jogadores Reais: para cada jogador, um Applet Java foi implementado, onde os jogadores podem escolher suas ações e também realizar a troca de informações com os outros jogadores (reais e/ou virtuais) via um chat pré-definido. No protótipo JogoMan, os jogadores não possuem uma interface computacional para acessar o simulador MABS, onde suas ações são anotadas em formulários de papel e entregues a um operador que as insere no simulador. Já no protótipo ViP-JogoMan, os jogadores acessam diretamente o simulador MABS, via uma interface gráfica.

- Camada de Comunicação:

- Comunicação entre os jogadores (reais e/ou virtuais): escolheu-se a plataforma SACI (Simple Agent Communication Infrastructure) (HUBNER; SICHMAN, 2000), que realiza comunicação a partir da linguagem 
KQML (Knowledge Query and Manipulation Language) (LABROU; FININ, 1997). O interpretador Jason possui uma API para utilizar a plataforma SACI, sendo a implementação da comunicação entre os jogadores facilitada.

- Comunicação entre os elementos MABS e RPG: escolheu-se o protocolo SOAP (Simple Object Access Protocol) (W3C, 2005), pois foi necessário um middleware entre o simulador Cormas e o interpretador Jason / Applets, visto que o primeiro foi desenvolvido em SmallTalk e o segundo em Java. Tanto SmallTalk quanto Java possuem APIs para SOAP. O formato das mensagens em SOAP é o XML, o que possibilita sua utilização na $W e b$.

O ViP-JogoMan segue a mesma seqüência de passos definida para o JogoMan, anteriormente apresentada pela Figura 13. Neste novo protótipo, o que foi alterado é que os jogadores poderão estar em lugares remotos, pois o jogo é jogado via Web, o que suprime o "Operador", pois o próprio jogador escolhe suas ações e as envia ao simulador Cormas, de forma automática.

A seguir, cada uma das ferramentas utilizadas para implementar o protótipo ViP-JogoMan será apresentada em um nível maior de detalhamento.

\subsection{Ferramenta MABS: Cormas}

Cormas (COmmon-pool Resources and Multi-Agent Systems) (CORMAS, 2006) é uma plataforma multiagentes especialmente desenvolvida para simulação de recursos naturais. Foi desenvolvida pela equipe Green-CIRAD (França) e neste trabalho foi utilizada a versão de Dezembro de 2005. Como este simulador é baseado na linguagem orientada a objetos SmallTalk, ele pode ser executado em diversos sistemas operacionais, como Linux e Windows. A versão do SmallTalk utilizada é o VisualWorks 7.3.1.

Cormas propõe uma forma de representação dos agentes a partir de um grid espacial. Os agentes podem ou não estar situados em uma posição do grid. Entretanto, na área de gestão de recursos naturais, a localização espacial é muito importante, porque algumas dinâmicas naturais são mais fáceis de descrever a partir do nível espacial e também porque a modelagem das ações do agente social (ator) está extremamente relacionada com o gerenciamento da unidade física (espacial) (BOUSQUET et al., 1999; DUCROT et al., 2004; D'AQUINO et al., 2003). 
Nos dois protótipos desenvolvidos, JogoMan e ViP-JogoMan, a unidade espacial é importante, pois é a partir destas unidades que os lotes pertencentes a cada jogador são definidos. Utiliza-se uma matriz $8 \times 8$ com 64 lotes e tem diferentes possibilidades de usos do solo, infra-estruturas e um dono (jogador).

Independente de como as ações são manipuladas dentro da ferramenta Cormas, é necessário que seja possível informar novos dados para o ciclo de simulação, e também extrair os dados após a manipulação pelo sistema. O Cormas permite tanto a leitura quanto a escrita em diversas formas, o que facilita tanto a comunicação quanto a análise de dados futuros. Contudo, não existe uma ferramenta interna que realize a análise de dados. No caso do protocolo SOAP, utilizado para realizar a comunicação entre a ferramenta MABS (Cormas) e os jogadores do RPG (Jason/Applets), o SmallTalk possui uma API ${ }^{1}$ que suporta esse protocolo e foi possível utilizar em Cormas todas as funcionalidades definidas em SOAP.

\subsection{Arquitetura Cognitiva dos Jogadores Virtu- ais}

\subsubsection{Linguagem AgentSpeak(L)}

AgentSpeak(L) (RAO; GEORGEFF, 1995) é uma linguagem lógica que implementa a arquitetura BDI, e seus elementos básicos são um conjunto de crenças e um conjunto de planos (RAO, 1996). Permite a definição de objetivos (predicados) para cada agente. Os objetivos podem ser de dois tipos:

- Objetivos de Realização (Achievement Goals): quando um agente quer executar um plano em um estado do mundo que está associado a um predicado verdadeiro.

- Objetivos de Teste (Test Goals): são o retorno da associação de um predicado com uma crença do agente.

Estes objetivos são prefixados com operadores '!' para objetivos de realização e '?' para os de testes.

Um evento inicializador (triggering event) define quais eventos podem iniciar a execução de um plano. Um evento pode ser interno, quando um sub-objetivo precisa ser realizado, ou externo, quando gerado por uma atualização de crença,

\footnotetext{
${ }^{1}$ Web Service Wizard API.
} 
como resultado da percepção pelo agente de seu ambiente. Existem dois tipos de evento inicializador: os que determinam uma adição ('+') ou os que determinam uma deleção ('-') dos estados mentais (crenças ou objetivos).

Planos especificam as ações básicas que um agente está habilitado a executar em seu ambiente. Estas ações são definidas como predicados de primeira ordem, mas com símbolos de predicados especiais (chamados símbolos de ação), usados para distinguí-los dos outros predicados. Um plano sempre terá um evento inicializador, seguido de uma conjunção de crenças literais, que representam um contexto. Para que um plano seja aplicável, o contexto deve ser uma seqüência lógica baseada em crenças atuais dos agentes, pois crenças antigas não podem ser testadas.

Um exemplo de implementação em $\operatorname{AgentSpeak(L)~de~um~plano~para~o~perfil~}$ comportamental com interesse econômico para o jogador Proprietário Particular é o seguinte:

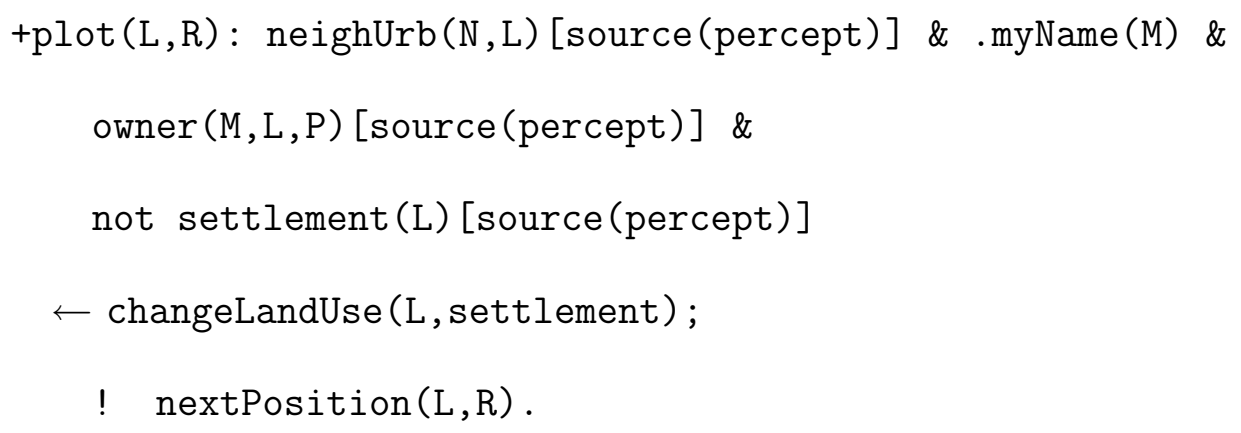

Este plano mostra um evento inicializador $(+p l o t(L, R))$, que indica o próximo lote a ser analisado. Se este lote for próximo a área urbana (neighUrb $(N, L)$ $[\operatorname{source}($ percept $)])$, pertencer ao próprio jogador (.myName(M) \& owner $(M, L, P)$ [source(percept)]) e não for um loteamento (not settlement(L) [source(percept)]), ele irá alterar o uso do solo para loteamento (estratégia número 1 deste perfil comportamental - ver seção 7.1), a partir da ação atômica changeLandUse(L, settlement), que enviará essa ação diretamente ao simulador Cormas. Em seguida, a partir de um objetivo de realização, o plano busca a próxima posição no espaço para agir (nextPosition $(L, R))$.

Todos os perfis comportamentais definidos no capítulo 7 foram implementados utilizando a linguagem AgentSpeak(L).

\subsubsection{Interpretador Jason}

Jason (Java-based $\boldsymbol{A}$ gentSpeak intepreter used with $\boldsymbol{S}$ aci for multi-agent distribution $\boldsymbol{O}$ ver the $\boldsymbol{N e t}$ )(BORDINI; HUBNER, 2004) é um intepretador para a lin- 
guagem AgentSpeak(L), que abrange todas as definições de $\operatorname{AgentSpeak(L)~e~mais~}$ algumas extensões definidas posteriormente por (BORDINI et al., 2002; MOREIRA; BORDINI, 2002; BORDINI et al., 2003; MOREIRA; VIEIRA; BORDINI, 2003; BORDINI; MOREIRA, 2004)), a fim de tornar a linguagem mais expressiva no uso de agentes cognitivos. Outra vantagem deste interpretador é que os agentes podem ser facilmente configurados para rodar em máquinas diferentes (fisicamente), com a utilização de SACI (Simple Agent Communication Infrastructure), que é uma ferramenta que provê infra-estrutura de comunicação para agentes (descrita na seção 8.5.2) que podem ser executados num ambiente distribuído (HUBNER; SICHMAN, 2000; HUBNER, 2003).

A maior diferença existente entre a linguagem $\operatorname{AgentSpeak(L)}$ padrão e a versão utilizada em Jason é que os predicados podem ter anotações, que são uma lista de termos que seguem o predicado. Estas anotações são utilizadas para registrar informações sobre o predicado. Existem dois tipos especiais de anotações, percept e self. O primeiro tipo denota uma crença sobre a percepção do ambiente e o segundo tipo explicita a adição de uma crença em sua própria base para a execução de um plano que exija que a crença seja adicionada.

Jason possui algumas ações padrão que facilitam sua utilização. Por exemplo, a ação send, que é uma ação interna de cada agente para comunicação interagentes, sendo utilizada no formato .send(receiver, illocutionary_forces, propositional_content), onde receiver é o agente que receberá a mensagem; illocutionay_forces determina o tipo de mensagem, podendo ser: tell, untell, achieve, unachieve, tellHow, untellHow, askIf, askHow ou askAll; e propositional_content contém o conteúdo da mensagem.

Os agentes definidos em AgentSpeak(L) devem ser colocados em arquivos de extensão .asl. Depois de definir as crenças e os planos dos agentes, é necessário definir ainda o ambiente onde os agentes se encontram, quais agentes fazem parte neste ambiente, e o tipo de arquitetura que o ambiente terá (centralizada ou distribuída).

A definição do ambiente é realizada em um arquivo Java (.class), que deve conter dados sobre o ambiente, como o seu tamanho (normalmente bidimensional, definido em uma matriz $\mathrm{N}$ x M) e indicações sobre como adicionar e/ou remover as percepções do ambiente. Jason implementa estas percepções em uma lista, e tem os métodos addPercept(percept) e removePercept(percept) definidos para inserção ou remoção das percepções do ambiente desta lista. Desta forma, é necessário definir que crenças relativas à percepção do ambiente serão incluídas e em que 
momento.

Jason cria um arquivo .xml com todas estas definições (agentes, ambiente e arquitetura). Para que os agentes definidos sejam iniciados de forma não gráfica, basta executar o comando:

\section{java org.apache.tools.ant.launch.Launcher -e -f build.xml}

Também é possível realizar todo o processo de definição dos arquivos asl e .xml através de uma interface gráfica, conforme apresentado na Figura 24, onde o perfil comportamental com interesse econômico para o papel de Proprietário Particular é apresentado. No caso dos jogadores virtuais definidos, a interface gráfica disponível em Jason não é utilizada, pois a integração com os jogadores reais pode ser mais facilmente realizada utilizando a forma não-gráfica, via linha de comando, visto que os jogadores virtuais são executados em um servidor de HTTP.

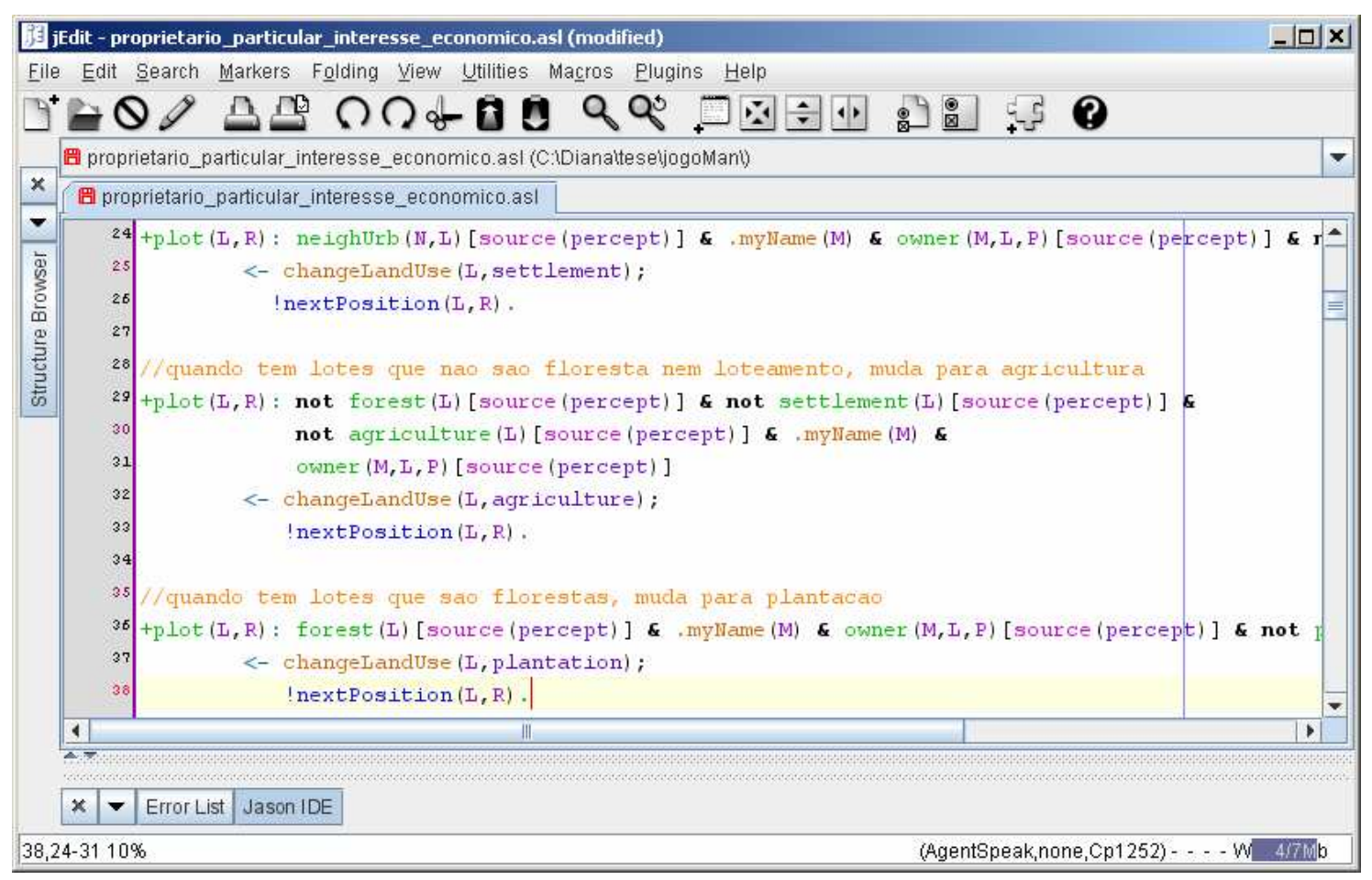

Figura 24: Interface gráfica do perfil comportamental com interesse econômico para o papel de Proprietário Particular, codificada em Jason.

\subsubsection{Protocolo de Negociação}

\subsubsection{Negociações Bilaterais}

As Negociações Bilaterais, que são ações que exigem negociação na Fase 1 da metodologia GMABS, para o protótipo ViP-JogoMan são: 
- Comprar/Alugar lote: pode ser realizada por todos os tipos de jogadores;

- Colocar infra-estrutura: os Proprietários Particulares e o Representantes dos SemTeto podem solicitar infra-estruturas, e os Prefeitos e o Administrador da AguaPura podem perguntar se os jogadores necessitam das infraestruturas;

- Buscar por Lote Específico: todos os jogadores podem solicitar a outro(s) jogador(es) informações sobre um tipo de lote específico.

As negociações bilaterais serão tratadas entre duas partes negociando e um objeto de negociação (2:1), seguindo a teoria de Raiffa, descrita na seção 2.4.2.

Um conjunto fechado de possíveis justificativas para as perguntas e/ou respostas foi definido para as negociações bilaterais e é apresentada no Anexo C. Este conjunto de justificativas foi analisado e validado pela pesquisadora Raphaèle Ducrot.

O protocolo de negociação da ação Comprar é apresentado na Figura 25. O protocolo foi desenvolvido, baseando-se nas especificações da FIPA-ACL (Foundation for Intelligent Phisical Agents - Agent Communication Language) (FIPA, 2002a) e Contract Net (FIPA, 2002b) . O comprador inicia o processo de negociação, enviando uma proposta de compra (Propose(action)). Quando recebe a proposta, o vendedor pode executar três diferentes ações: (i) rejeitar a proposta (Reject_proposal(action)); (ii) solicitar uma nova contra proposta de compra (Request(action)); (iii) aceitar a proposta feita pelo comprador (Accept_proposal(action)). A ação de rejeitar a proposta é final; a ação de solicitar uma contra proposta implica que o comprador faça uma nova proposta (Propose(action)) - esta ação é, em prática, a utilização da Teoria de Raiffa, onde com o envio de contra propostas, espera-se chegar ao "Intervalo Comum" de Negociação; e a ação de aceitar a proposta feita implica no comprador informar o ambiente (no caso, o simulador) sobre a ação a ser efetuada no jogo ( $I n$ form(action)). O protocolo de negociação para as ações Alugar e Buscar por Lote Específico são exatamente iguais ao da ação Comprar.

O protocolo de negociação da ação Colocar Infra-estrutura é apresentado na Figura 26. O Proprietário inicia o processo de negociação, enviando uma solicitação de infra-estrutura ao Prefeito ou ao Administrador da AguaPura (Request(action)). Quando recebe a solicitação, o Prefeito (ou AguaPura), pode confirmar a mesma (Confirm(action)) ou recusá-la (Refuse(action)). A ação de recusar é final e pelas especificações da FIPA, uma mensagem do tipo Refuse sem- 


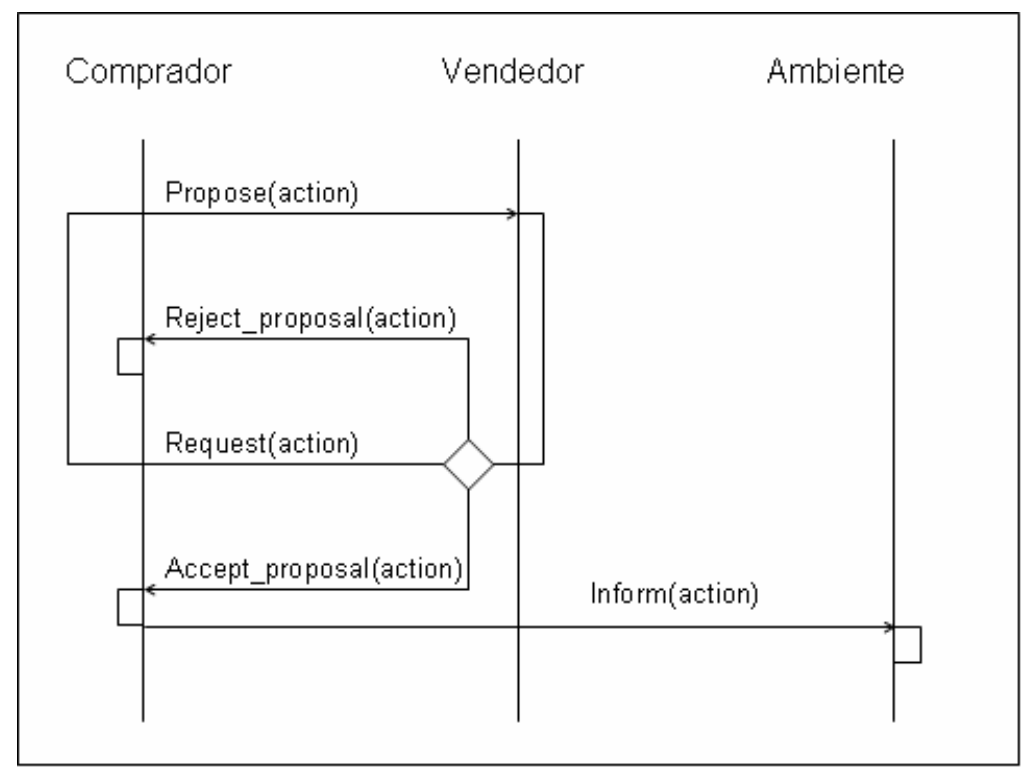

Figura 25: Protocolo de Negociação para as Ações Comprar, Alugar e Buscar por Lote Específico.

pre apresenta o motivo de não estar executando a ação solicitada. Desta forma, caso a solicitação seja recusada, o Proprietário saberá o motivo da recusa, como a falta de recursos públicos para a realização da infra-estrutura. Confirmar a ação implica no Prefeito (ou AguaPura) em informar o ambiente sobre a ação a ser efetuada no jogo (Inform(action)).

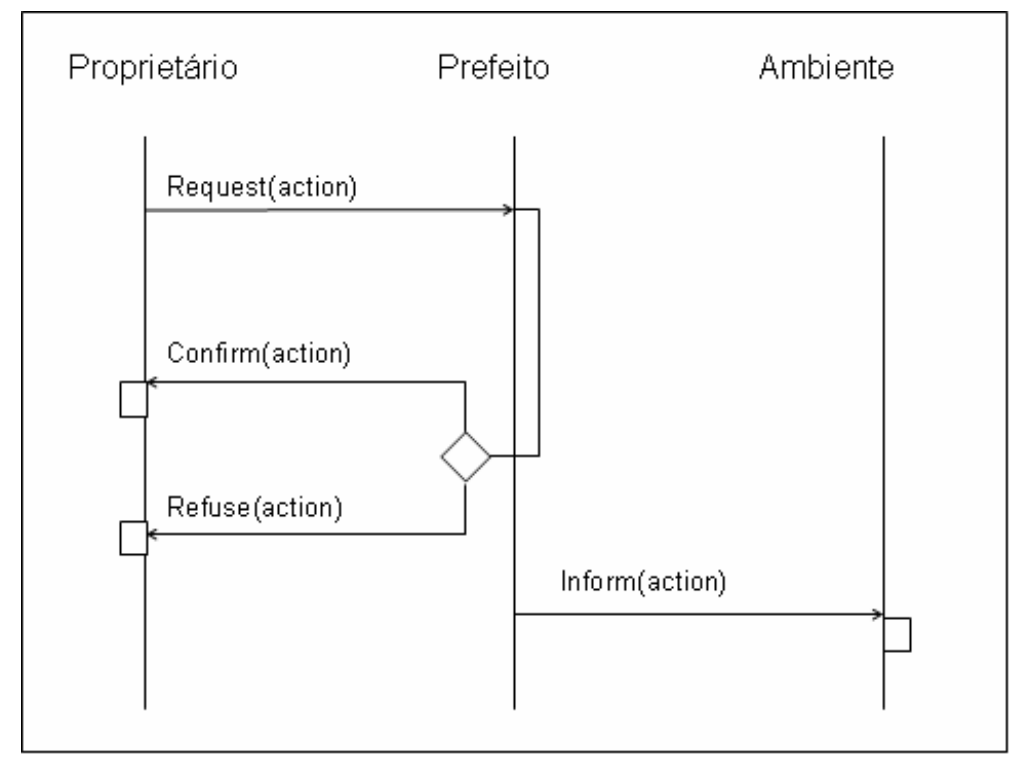

Figura 26: Protocolo de Negociação para as Ações de Colocar Infra-estrutura.

\subsubsection{Negociações Coletivas}

Para as Negociações Coletivas, referentes à Fase 2 da metodologia GMABS e representadas pela Reunião do Comitê de Bacia, todas as estratégias coletivas 
são consideradas negociáveis e envolvem todos os jogadores. Desta forma, o protocolo de negociação poder ser considerado como um broadcast. As negociações coletivas serão tratadas entre $\boldsymbol{n}$ partes negociando e $\boldsymbol{n}$ objetos de negociação ( $\boldsymbol{n}: \boldsymbol{n})$, seguindo a teoria de Raiffa, descrita na seção 2.4.2.

Também para as negociações coletivas, um conjunto fechado de possíveis estratégias coletivas foi definido e validado pela pesquisadora Raphaèle Ducrot. Todas as estratégias coletivas definidas encontram-se no Anexo D.

Contudo, para que as negociações coletivas possam acontecer, é necessário definir estratégias coletivas no escopo do protótipo ViP-JogoMan. Estratégias coletivas são definidas a partir da tupla \{estratégia, ação, justificativa\}. A estratégia é a proposta de negociação em mais alto nível, ou seja, a "sugestão" de mudança desejada. A ação é a forma que a estratégia proposta pode ser executada pelos jogadores, e a justificativa define o porquê do jogador escolher tal estratégia e possível ação a ser tomada, podendo ser uma justificativa a favor (concordando com a estratégia coletiva proposta) ou contra (discordando com a estratégia coletiva proposta).

Dentro do processo de negociação, a estratégia é o Objeto de Negociação, pois ela é o alvo de discussão. Contudo, uma estratégia nunca pode estar separada de uma possível ação e sua justificativa, senão esta perde significado. Por exemplo, em um processo de negociação coletiva, não basta apenas "lançar" a idéia de Ampliar a rede de água, tem-se também que propor uma forma de realizar essa estratégia, a partir de uma ação, como Prefeitos repassam dinheiro para AguaPura colocar infra-estruturas, bem como o porquê dessa escolha, a partir de uma justificativa, como Sou Prefeito e acho que ampliar a rede de água e necessário para manter a qualidade de água dos mananciais.

Existem quatro tipos de negociações coletivas possíveis aos jogadores:

1. Propor uma nova estratégia coletiva;

2. Concordar com uma estratégia coletiva existente;

3. Não concordar com uma estratégia coletiva existente;

4. Fazer uma contra-proposta a uma estratégia coletiva existente.

Quando uma nova proposta coletiva é realizada, o jogador deve escolher a Estratégia, a Ação e a Justificativa, assim todos os jogadores poderão analisar a estratégia proposta e negociar a partir da mesma. Se um jogador concordar 
com a proposta feita, este deve escolher a mesma Estratégia e Ação do jogador que fez a proposta, mas pode alterar sua Justificativa (provavelmente a favor), dizendo porque considera essa estratégia importante (concorda). Se um jogador não concordar com a proposta feita, este deve escolher a mesma Estratégia e Ação do jogador que fez a proposta, mas pode alterar sua Justificativa (provavelmente contra), dizendo porque acha que a estratégia proposta não é importante (não concorda). Para realizar uma contra-proposta, se um jogador concorda com a estratégia proposta, mas não concordar com a Ação para realização desta estratégia, ele pode fazer uma proposta para a mesma estratégia com uma Ação diferente e uma Justificativa para isso, explicando o porquê de sugerir outra ação para a mesma estratégia.

Todas as estratégias, ações e justificativas apresentadas aos jogadores são um conjunto fechado de possibilidades, ou seja, os jogadores devem escolher entre as possíveis estratégias existentes, apresentadas no Anexo D. Estas estratégias foram definidas a partir da observação das reuniões do Comitê de Bacia realizadas nos jogos de mesa do JogoMan, e foram analisadas e validadas pela coordenadora do Projeto Negowat, professora Raphaèle Ducrot.

Um exemplo de negociação coletiva seria o seguinte:

1. Um jogador no papel de Prefeito lança uma nova estratégia coletiva formada pela seguinte tupla:

- Estratégia: Delimitar área urbana de meu município;

- Ação possível: Prefeitos se comprometem a não instalam infra-estruturas de escola, posto de polícia ou posto de saúde fora destas áreas;

- Justificativa a favor: Sou Prefeito e acredito que as infra-estruturas devem ficar na área urbana.

2. A seguir, um jogador no papel de Proprietário Particular responde a esta estratégia concordando com a mesma, a partir da seguinte tupla:

- Estratégia: Delimitar área urbana de meu município;

- Ação possível: Prefeitos se comprometem a não instalam infra-estruturas de escola, posto de polícia ou posto de saúde fora destas áreas;

- Justificativa a favor: Sou Proprietário Particular e acredito que áreas mais afastadas devem ser preservadas.

3. Contudo, um outro jogador no papel de Proprietário Particular responde a esta estratégia não concordando com a mesma, a partir da tupla: 
- Estratégia: Delimitar área urbana de meu município;

- Ação possível: Prefeitos se comprometem a não instalam infra-estruturas de escola, posto de polícia ou posto de saúde fora destas áreas;

- Justificativa contra: Sou Proprietários Particular em áreas afastadas e preciso valorizar o meu patrimônio fundiário.

4. Finalmente, o jogador no papel do Representante dos SemTeto responde a esta estratégia propondo uma nova idéia para a mesma estratégia (contraproposta), alterando a ação possível e a justificativa, a partir da tupla:

- Estratégia: Delimitar área urbana de meu município;

- Ação Possível: SemTeto não compram, nem invadem áreas fora do limite determinado

- Justificativa a favor: Sou SemTeto e tenho preferência por ficar em lotes próximos a área urbana, com mais infra-estruturas e empregos.

\subsubsection{Negociações Bilaterais e Coletivas nos Perfis Comportamen- tais}

Os perfis comportamentais têm implementados os mesmos protocolos de negociação definidos nas seções 8.3.3.1 e 8.3.3.2 para negociações bilaterais e coletivas do protótipo ViP-JogoMan. Entretanto, cada perfil pode utilizar apenas um subconjunto destas estratégias de negociação bilateral e/ou coletiva, e estas descrições encontram-se nos Anexo C e D, respectivamente.

Como as negociações bilaterais e coletivas fazem parte da base de conhecimento de cada perfil comportamental definido, todas as informações referentes as negociações (Anexos C e D) para os perfis comportamentais foram implementadas em AgentSpeak(L).

\subsection{Interfaces dos Jogadores Reais}

Para cada papel do ViP-JogoMan (Proprietário Particular, administrador da AguaPura, Prefeito e Representante dos SemTeto) foram implementados Applets Java. Estes applets são interfaces gráficas disponibilizadas via Web, para acesso remoto dos jogadores.

Para acessar a interface de um tipo de papel específico, primeiramente o participante do jogo deve acessar a página inicial do jogo, apresentada na Figura 27. 


\begin{tabular}{|c|c|}
\hline 장 JOGOMAN - Escolha Jogador - Copyright @ LTI/POLI/USP - Mozilla Firefor & 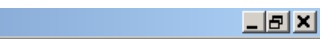 \\
\hline Eile Edit Wiew Go Bookmarks Iools Help & $\%$ \\
\hline 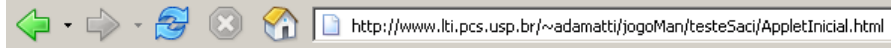 & I (1) Go G \\
\hline
\end{tabular}

\section{JogoMan - Jogo dos Mananciais}

Este jogo é parte do Projeto Negowat: Facilitating Negotiations Over Land and Water Conflicts in Latin American Peri-Urban Upstream Catchments: Combining Multi-Agent Modelling with Role-Playing Games.

Financiado pela Comunidade Européia e pela FAPESP.

O JOGOMAN envolve problemas de gerenciamento de água, de uso do solo e de pressẫo urbana em três diferentes cidades.

Escolha um jogadores ainda disponíveis para jogar: \begin{tabular}{|l|l|}
\hline Proprietário Particular 3 & $>$ \\
\hline
\end{tabular}

Créditos

Universidade de Sẫo Paulo

Escola Politécnica - Engenharia Elétrica

Departamento de Engenharia de Computaçẫo e Sistemas Digitais

Laboratório de Técnicas Inteligentes

Diana F. Adamatti - diana.adamatti@poli.usp.br

Jaime S. Sichman - jaime.sichman@poli.usp.b

Copyright@LLTISOLIIUSP

Figura 27: Interface Inicial de Acesso ao Jogo.

Nesta interface, são apresentados dados sobre o jogo, créditos de desenvolvimento e um ComboBox de seleção do jogador (pelo nome que utilizará no jogo). Assim, se um participante escolher o jogador "Proprietário Particular 3", desempenhará o papel de um Proprietário Particular.

Nas Figuras 28, 29, 30 e 31 são apresentadas as diferentes interfaces, para a Fase 1, dos diferentes papéis existentes no jogo. Em todas estas interfaces, há uma divisão entre escolha e confirmação de ações da rodada e comunicação com outros jogadores. Na parte superior, os jogadores podem escolher as ações a tomar. Por exemplo, na Figura 28 é apresentada a interface do Administrador da AguaPura, e este papel pode: comprar ou alugar lotes, modificar o uso do solo, colocar infra-estruturas, modificar impostos sobre a distribuição de água e a coleta de esgoto ou transferir dinheiro para qualquer outro jogador. Pode-se verificar pelas Figuras 29, 30 e 31 que os outros papéis têm possibilidades de execução de ações diferentes, dependendo das regras definidas, descritas no capítulo 5.

Na parte inferior da Figura 28 é apresentada a forma de troca de mensagens com os demais jogadores. Este jogador pode enviar uma mesma mensagem para 1 ou n outros jogadores, selecionando o tipo de mensagem a ser enviada, especificando o número do lote em negociação, o valor (quando se aplicar) e a justificativa 
da mensagem, podendo todas as justificativas serem acessadas no Anexo C. Um exemplo de envio de mensagem para compra de um lote é a seguinte:

- Selecionar o jogador "proprietário 1";

- Selecionar o tipo de mensagem "proposta";

- Selecionar o lote número "3";

- Digitar o valor "2000";

- Selecionar a justificativa "Este lote fica próximo a área urbana, e quero construir uma indústria /comércio / loteamento";

- Pressionar o botão "Envia Msg".

Com esta mensagem, o jogador está enviando uma mensagem ao jogador proprietário 1, fazendo uma proposta de compra do lote 3, pelo valor de $\mathrm{R} \$ 2.000,00$, e tendo como justificativa a proximidade do lote a área urbana.

A interface gráfica de negociação descrita acima para o papel de Administrador da AguaPura é igual para todos os papéis, conforme mostram as Figuras 29, 30 e 31 .

Também nas Figuras 28, 29, 30 e 31 verifica-se que todos os papéis têm disponíveis quatro botões de informações: MAPA, Custos e Ganhos, Regras do Jogo e Ações Coletivas. O primeiro botão, MAPA, apresenta os lotes de cada jogador (no caso dos proprietários e do Representante dos SemTeto); os Prefeitos vêem toda sua cidade e o Administrador da AguaPura vê toda a região. O segundo botão, Custos e Ganhos, apresenta os pagamentos (impostos, compra de lotes, etc.) e os ganhos (rendimento de um tipo de uso do solo, etc.) da rodada anterior apenas do próprio jogador. O terceiro botão, Regras do jogo, apresenta as regras do jogo específicas de cada um dos quatro papéis. Já o quarto botão, Ações Coletivas, apresenta as ações coletivas tomadas na rodada anterior por todos os jogadores.

A Figura 32 apresenta a Fase 2 (coletiva) do jogo, representada pela Reunião do Comitê de Bacia. Nesta interface são apresentadas as estratégias coletivas pré-definidas, conforme mostra o Anexo D. Esta interface é apresentada de modo igual a todos os papéis. Seguindo a mesma idéia de divisão da interface, na parte superior, os jogadores podem escolher as estratégias, possíveis ações e justificativas, e enviar enviar a mensagem, pressionando o botão "Envia Mensagem a todos os outros Jogadores". Na parte inferior da interface são apresentadas todas as 


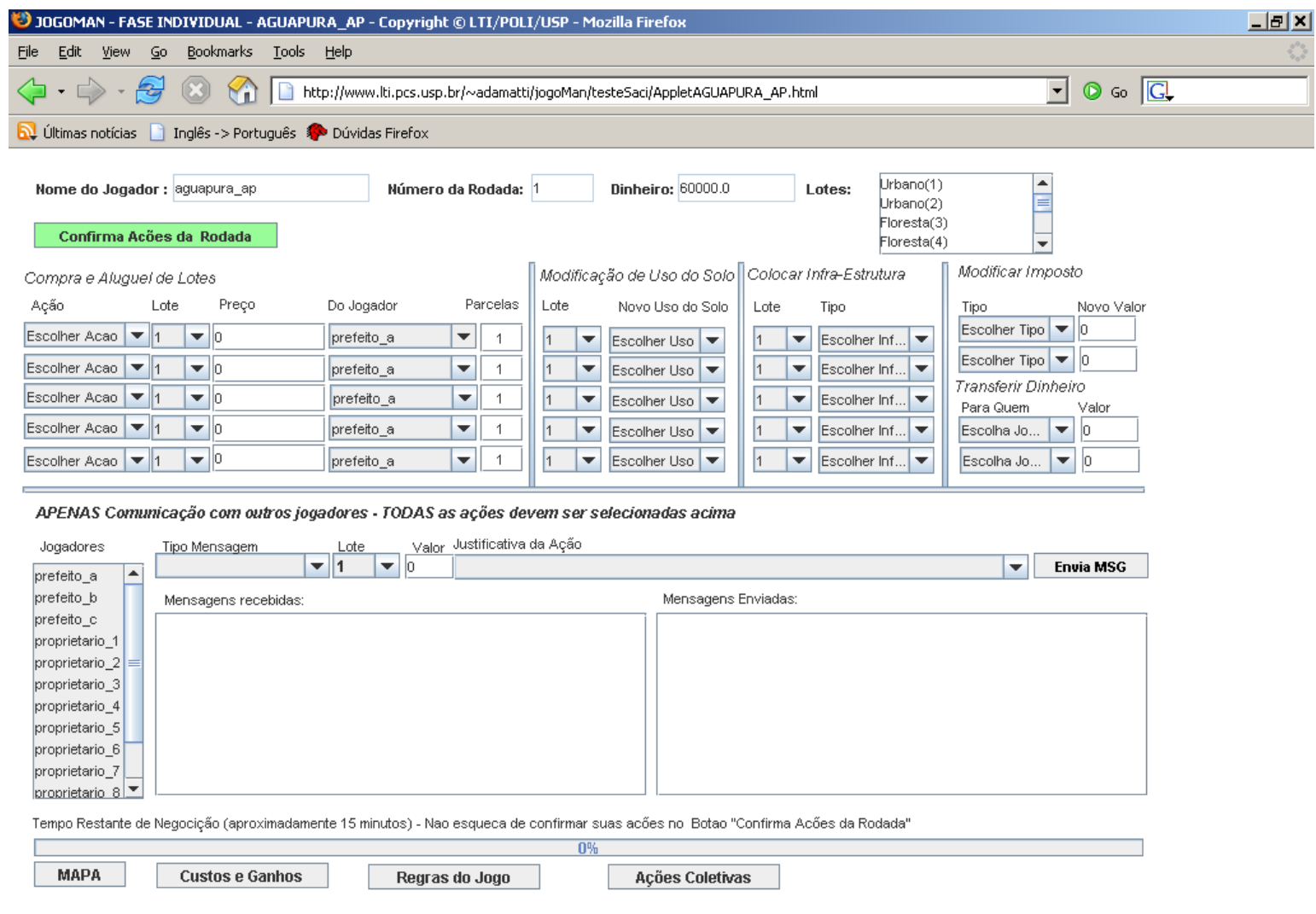

Applet aguapura_ap started

Figura 28: Interface do Administrador da AguaPura.

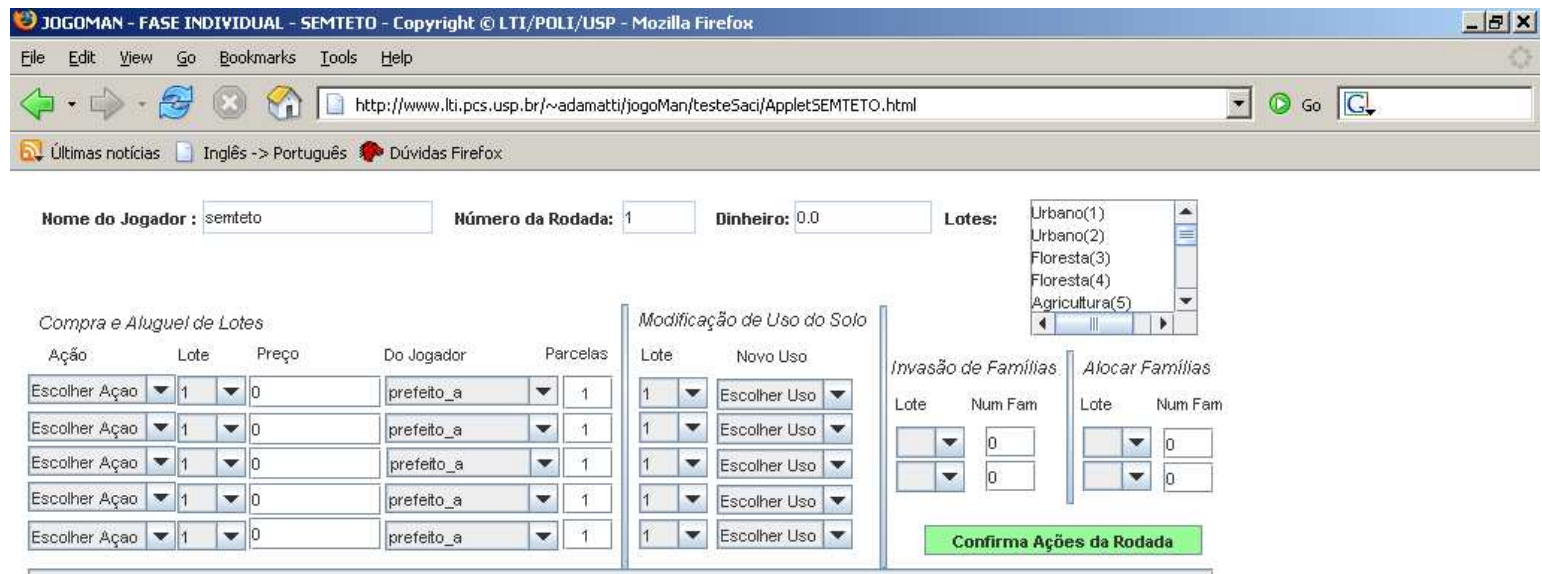

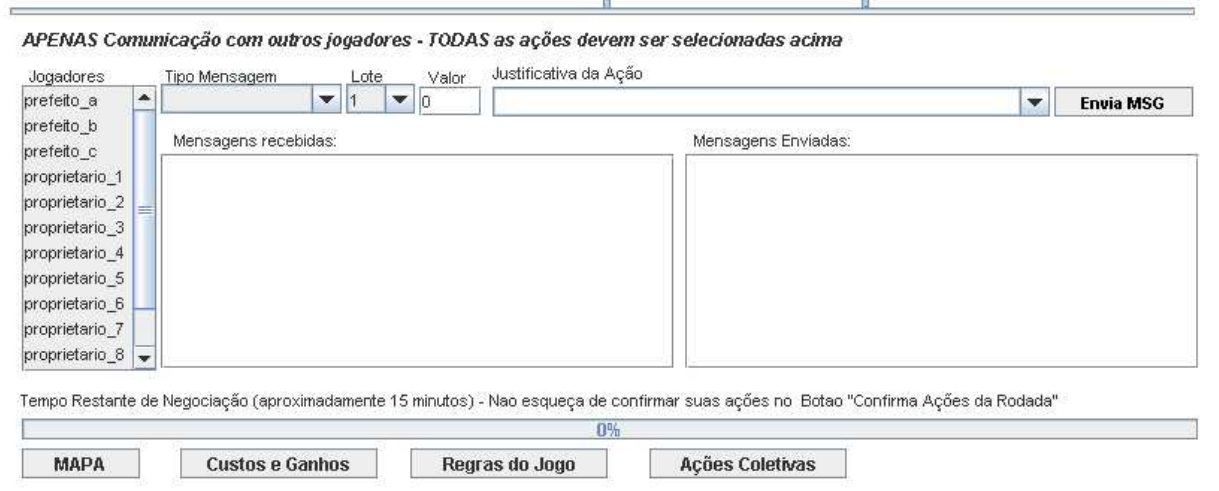

Figura 29: Interface do Representante dos SemTeto. 


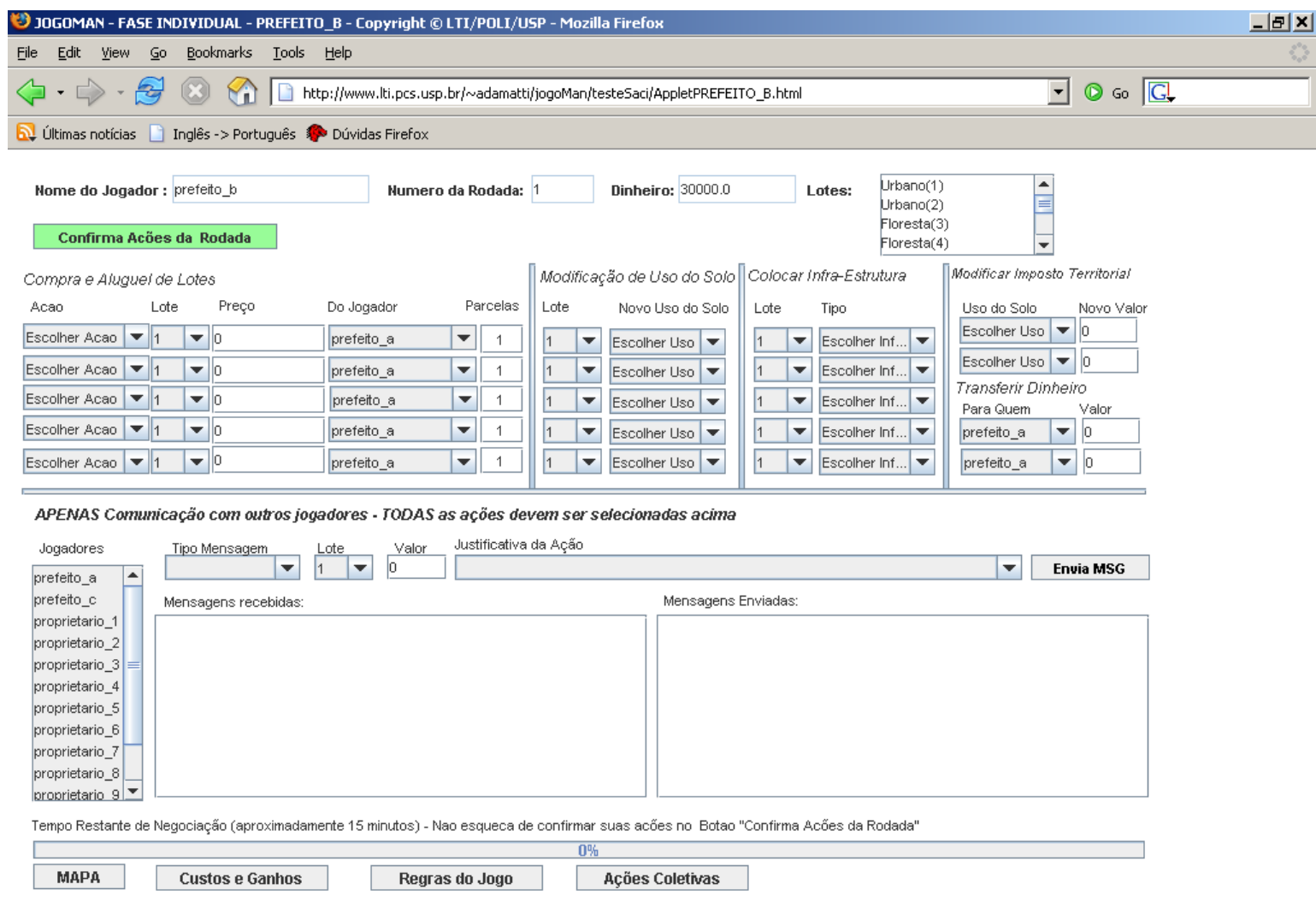

Applet prefeito_b started

Figura 30: Interface dos Prefeitos.

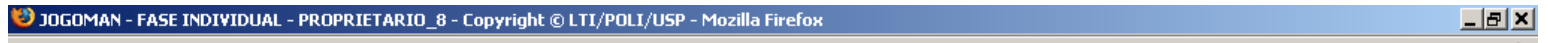

Eile Eddit Wiew $\underline{\underline{G} 0}$ Bookmarks Iools Help

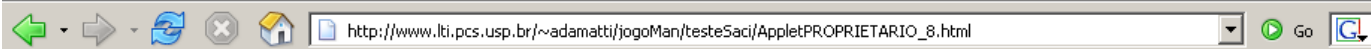

Qu últimas noticias $\square$ Inglês -> Português Dúvidas Firefox

Home do Jogador : proprietario_8

Múmero da Rodada: 1

Dinheiro: 2000.0

Lotes:

Compra e Aiuguel de Lotes

\begin{tabular}{|c|c|c|c|c|c|c|}
\hline Açẫo & & & Preco & Do Jogador & & elas \\
\hline Escolher Acao & $\nabla$ & 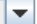 & & prefeito_a & $\nabla$ & 1 \\
\hline Escolher Acao & $\nabla$ & $\nabla$ & & prefeito_a & $\nabla$ & 1 \\
\hline Escolher Acao & $\nabla 1$ & $\nabla$ & & prefeito_a & $\nabla$ & 1 \\
\hline Escolher Acao & $\nabla$ & $\nabla$ & 0 & prefeito_a & $\nabla$ & 1 \\
\hline Escolher Acao & $\nabla$ & - & & prefeito_a & $\nabla$ & 1 \\
\hline
\end{tabular}

Modificação de Uso do Solo de Lotes

Lote Novo Uso do Solo

\begin{tabular}{|l|l|l|l|}
\hline 1 & $\mathbf{V s c o l h e r ~ U s o ~}$ & $\mathbf{V}$
\end{tabular}

\begin{tabular}{l|l|l|l|l|}
\hline 1 & $\mathbf{V}$ & Escolher Uso & $\mathbf{V}$
\end{tabular}

\begin{tabular}{l|l|l|l|l|}
\hline 1 & $\mathbf{V}$ & Escolher Uso & $\mathbf{V}$ \\
\hline
\end{tabular}

\begin{tabular}{|l|l|l|l|l|}
\hline 1 & $\mathbf{V}$ & Escolher Uso & $\mathbf{V}$
\end{tabular}

\begin{tabular}{l|l|l|l|l|}
\hline 1 & $\mathbf{V}$ & Escolher Uso & $\mathbf{V}$
\end{tabular}

APENAS Comunicação com outros jogadores - TODAS as açöes devem ser sejecionadas acima

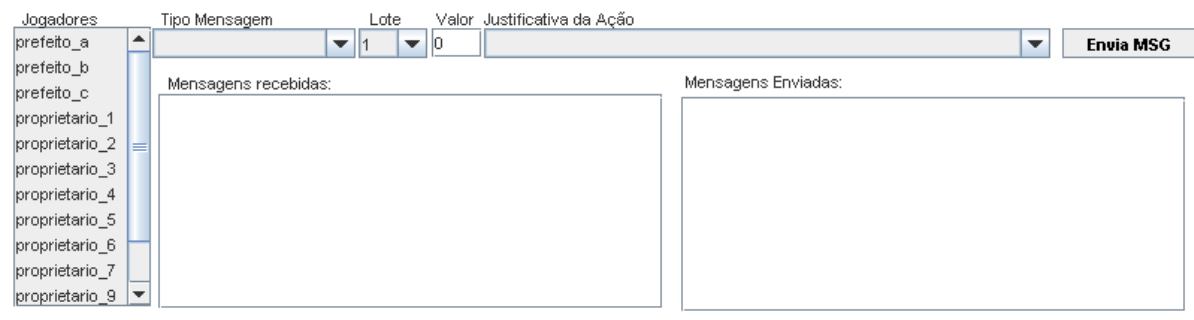

Tempo Restante de Negociacao (aproximadamente 15 minutos) - Nao esqueca de confirmar suas acôes no Botao "Contirma Acổes da Rodada"

$0 \%$ \%

\begin{tabular}{l|l|l|}
\hline MAPA & Custos e Ganhos & Regras do Jogo \\
\hline
\end{tabular}

Figura 31: Interface dos Proprietários Particulares. 


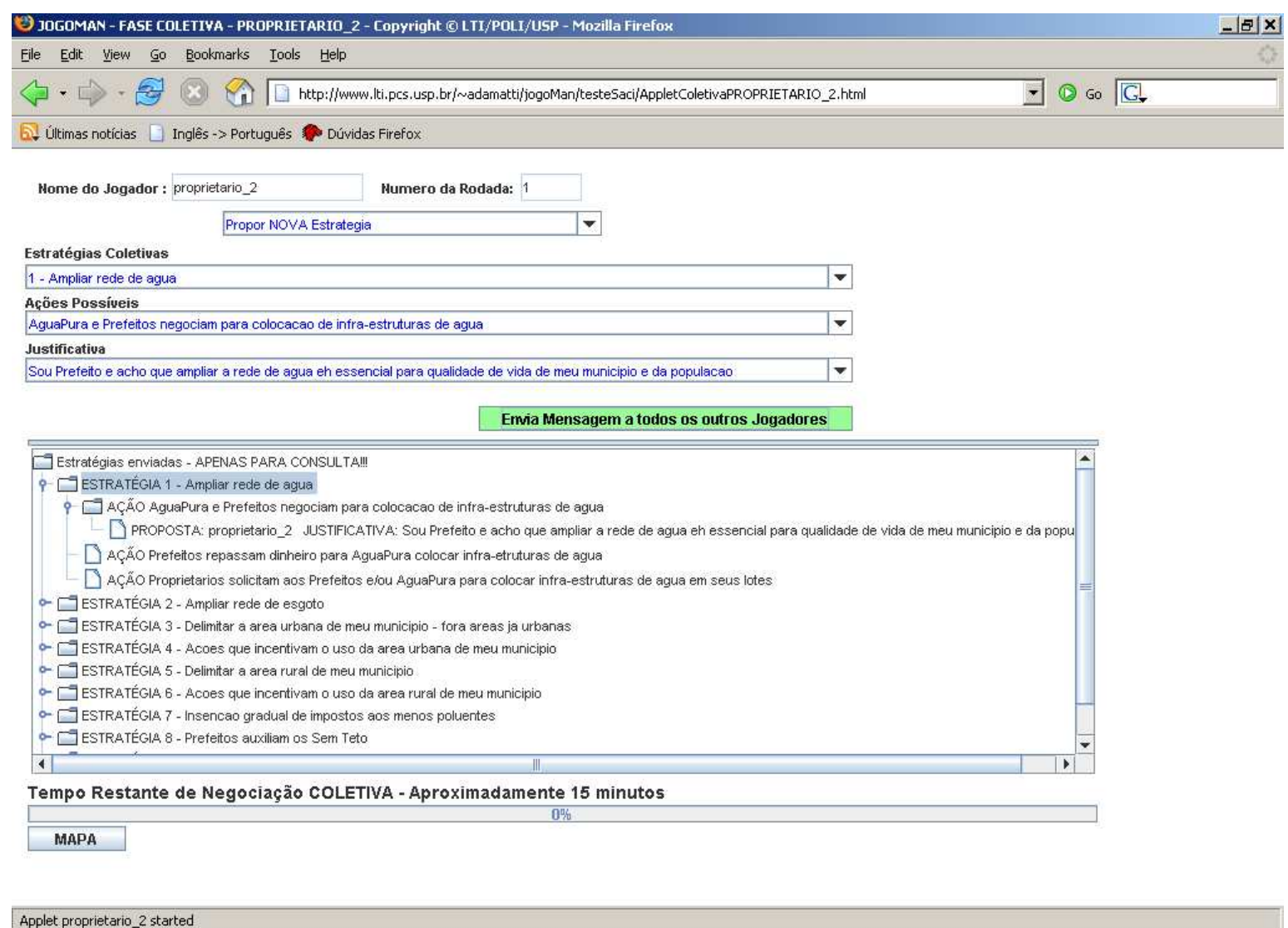

Applet proprietario_2 started

Figura 32: Interface de Interação Coletiva para Todos os Papéis.

mensagens já enviadas pelos jogadores (incluindo o próprio jogador), em ordem cronológica de envio. Ainda é possível nesta parte do jogo visualizar o mapa, pressionando o botão MAPA.

\subsection{Camada de Comunicação: Protocolo SOAP e SACI}

\subsubsection{Protocolo SOAP}

O Protocolo SOAP (Simple Object Access Protocol) (W3C, 2005) é um protocolo para a troca de informações em ambientes distribuídos e descentralizados, como é o ambiente da Internet (ROMMEL, 2006). A idéia do protocolo SOAP é habilitar a comunicação de dois processos, desconsiderando o hardware e/ou software utilizado. SOAP define uma gramática XML especializada, porém flexível, que padroniza o formato das estruturas das mensagens.

As funcionalidades previstas do SOAP são (W3C, 2005):

- Interoperabilidade entre sistemas utlizando linguagens e protocolos padronizados largamente difundidos, como XML; 
- Permitir a comunicação entre sistemas protegidos por firewalls, sem precisar abrir portas adicionais e possivelmente não-seguras, pois utiliza normalmente a porta 80 ;

- Descrever completamente cada elemento da mensagem, facilitando o entendimento e a proteção contra erros.

Sendo assim, este protocolo acaba com a disputa entre linguagens, garantindo que o programador possa desenvolver sua aplicação no ambiente que seja mais adequado às suas necessidades (ROMMEL, 2006).

No caso do ViP-JogoMan, o simulador Cormas foi desenvolvido em SmallTalk e o interpretador Jason, bem como os Applets dos jogadores reais, foram desenvolvidos em Java. As duas linguagens possuem APIs para SOAP, sendo o processo de comunicação entre as linguagens bastante facilitado e ocorrendo de forma completa (sem perda de dados) e segura.

Na linguagem SmallTalk, a definição dos serviços e comunicação disponíveis via SOAP é declarada da seguinte maneira:

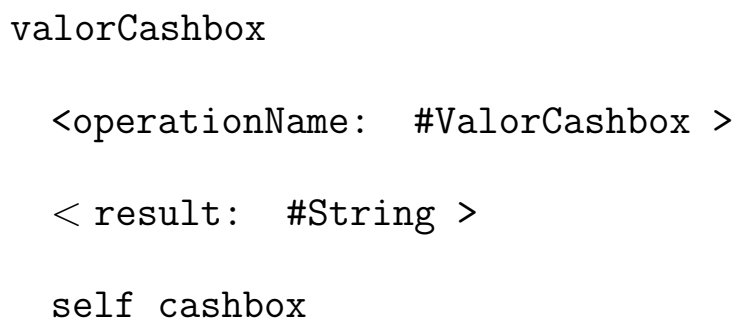

Neste exemplo, o serviço irá retornar o valor da poupança (cashbox) para todos os jogadores na rodada atual do jogo. Os dados entre $<>$ estão no padrão definido pelo W3C para comunicação (W3C, 2005).

Na linguagem Java, a definição dos serviços e comunicação disponíveis via SOAP está definida no pacote javax.xml.soap.*.

\subsubsection{SACI}

A plataforma SACI (Simple Agent Communication Infrastructure) (HUBNER; SICHMAN, 2000) é uma ferramenta para comunicação entre agentes, que utiliza a linguagem KQML (Knowledge Query and Manipulation Language) (LABROU; FININ, 1997).

SACI possui as seguintes características (HUBNER; SICHMAN, 2000):

1. Os agentes utilizam KQML para se comunicar. Há funções para compor, 
enviar e receber mensagens KQML;

2. Os agentes são identificados por um nome. As mensagens são transportadas utilizando-se somente o nome do receptor, sua localização na rede é transparente;

3. Um agente pode conhecer os outros por meio de um serviço de páginas amarelas. Agentes podem registrar seus serviços no facilitador e perguntálo sobre que serviços são oferecidos por quais agentes;

4. Os agentes podem ser implementados como applets e terem sua interface em uma homepage;

5. Os agentes podem ser iniciados remotamente;

6. Os agentes podem ser monitorados. Os eventos sociais (entrada na sociedade, saída, recebimento ou envio de mensagens) podem ser visualizados e armazenados para análise futura.

Dentre as características especificadas acima, duas são importantes para o protótipo ViP-JogoMan: o fato dos agentes poderem ser implementados como applets (4) e o fato dos agentes poderem ser iniciados remotamente (5), pois deseja-se que cada jogador possa iniciar o jogo via Web, e mesmo assim, este jogador possa ser monitorado e realizar a comunicação com os outros jogadores.

Além disso, como já citado na seção 8.3.2, o interpretador Jason utiliza SACI para realizar a comunicação entre os agentes definidos.

Tanto os jogadores virtuais quanto os jogadores reais realizam trocas de mensagens via SACI. Para os jogadores reais, cada Applet Java realiza uma conexão com à plataforma SACI no momento que é acessado remotamente, via Web. Para os jogadores virtuais, o próprio Jason se encarrega de realizar a conexão de todos os agentes iniciados no interpretador.

\subsection{Considerações Finais}

Este capítulo apresentou como o protótipo ViP-JogoMan foi definido e implementado. Todas as ferramentas escolhidas para esta implementação foram apresentadas. Estas ferramentas atendem aos requisitos definidos para a arquitetura ViP-GMABS, definidos no capítulo 6. 
Na parte III, apresentada a seguir, são discutidos e analisados os resultados dos testes realizados com o protótipo ViP-JogoMan. 


\section{Parte III}

\section{Resultados Obtidos}




\section{Metodologia para Avaliação do Protótipo ViP-JogoMan}

Este capítulo apresenta a metodologia adotada para avaliar a inserção de jogadores virtuais na arquitetura ViP-GMABS, cujo escopo é discutido na seção 9.1. Três formas de avaliação foram adotadas: avaliação dos perfis comportamentais definidos, questionários aos jogadores reais e análise de troca de mensagens entre jogadores, apresentadas respectivamente nas seções 9.2, 9.3 e 9.4. As considerações finais deste capítulo encontram-se descritas na seção 9.5.

\subsection{Escopo da Avaliação}

Um dos interesses deste trabalho é avaliar como os jogadores virtuais inseridos na metodologia GMABS podem contribuir na apresentação de novas visões do jogo, bem como poderiam ser projetados e implementados de modo a não serem facilmente "descobertos" pelos jogadores reais. Como apresentado no capítulo 4, não foram encontrados trabalhos que realizem avaliação da metodologia GMABS. Assim, decidiu-se estudar como é realizada a avaliação em áreas correlacionadas a deste trabalho. Uma destas áreas é a de Interfaces Inteligentes (Agentes Assistentes), que possui alguns aspectos similares aos objetivos propostos aos jogadores virtuais. Por exemplo, as Interfaces Inteligentes apresentam aos usuários o sistema de maneira dinâmica e autônoma, auxiliando na realização de tarefas, dando dicas, etc. Deseja-se que os jogadores virtuais apresentem novas visões do jogo aos jogadores reais, também de maneira autônoma e dinâmica.

A inserção de jogadores virtuais na metodologia GMABS possibilita realizar diversas formas de avaliação, dependendo do foco de estudo. Dentro dos objetivos deste trabalho, deseja-se encontrar respostas as seguintes questões, conforme enunciado na seção 1.4:

1. Os comportamentos de cada tipo de jogador virtual foram definidos de forma que a tomada de decisão dos mesmos não fosse trivial? 
2. A capacidade de discussão e aprendizado do RPG foi mantida com a inclusão de jogadores virtuais? As negociações e interações para tomada de decisão continuarão ocorrendo entre os jogadores reais e/ou virtuais?

3. A realização do jogo via $W e b$ dificultou a interação entre os jogadores, sejam eles reais ou virtuais?

A partir destas três perguntas, foram definidas três formas de avaliação para os testes com Jogadores Virtuais:

- Definição de Perfis Comportamentais: para todos os papéis do jogo foram definidos perfis de comportamento (Proprietários Particulares, Prefeito, Administrador da AguaPura e Representante dos SemTeto), apresentados no capitulo 7. Estes perfis têm objetivos definidos, e para realizar a avaliação será necessário analisar certas variáveis de forma quantitativa. Estas variáveis terão relação direta com os objetivos definidos para cada perfil. Por exemplo, se um Proprietário Particular utilizar um perfil com interesse econômico, a variável a ser analisada será a poupança adquirida, a fim de verificar se a renda deste Proprietário Particular aumentou, ou se, comparativamente aos outros jogadores, é mediana ou superior.

Perfis comportamentais são muito utilizados na área de IHC, normalmente utilizando o método de avaliação "Análise de Conversação e de Interação", definido no capítulo 4.

A avaliação das variáveis dos perfis comportamentais tem por objetivo responder de forma quantitativa à primeira questão, relacionada a tomada de decisão dos jogadores virtuais.

- Aplicação de Questionários aos jogadores reais (pré e pós-jogo): o questionário pré-jogo tem o intuito de verificar o nível de conhecimento dos jogadores reais, para o domínio do problema, RPGs e uso da Internet. O questionário pós-jogo verificará se o jogo atingiu os objetivos propostos, bem como se a negociação ocorreu de maneira similar à negociação face a face, dos jogos de mesa. Também verificará se os jogadores virtuais foram verossímeis aos "olhos" dos jogadores reais.

Segundo Dennis e Valacich (DENNIS; VALACICH, 2001), o uso de questionários auxilia de forma direta na identificação dos usuários e da percepção dos mesmos em relação ao sistema que está sendo testado. 
A maioria das avaliações na área de jogos computacionais utiliza questionários, baseado no método de avaliação Entrevistas, Questionários, Grupos de Trabalho e Feedback, definido no capítulo 4.

A análise dos questionários aplicados aos jogadores reais tem por objetivo responder de forma qualitativa às três questões, pois nos questionários propostos (apresentados na seção 9.3), existem perguntas relacionadas aos jogadores virtuais, à interação com os jogadores e à inserção da tecnologia (computador).

- Análise de Trocas de Mensagens entre Jogadores: todas as trocas de mensagens realizadas pelos jogadores serão armazenadas em arquivos de Log para análise. Serão analisadas as negociações bilaterais e coletivas de todos os jogadores.

Este tipo de avaliação é baseada no método de "Análise de Conversação e de Interação", definido no capítulo 4. Este método busca avaliar a interação entre as pessoas e das pessoas com a nova tecnologia.

As informações obtidas a partir da análise das trocas de mensagens entre os jogadores têm por objetivo responder de forma quantitativa à segunda e à terceira questões, relacionadas à interação entre os jogadores e à inserção da tecnologia (computador).

Estas formas de avaliação são discutidas nas próximas seções.

\subsection{Avaliação dos Perfis Comportamentais}

Para verificar se os perfis comportamentais foram implementados de forma correta e se atendem aos objetivos definidos, foram escolhidas 8 variáveis para análise. Esta avaliação é feita de forma quantitativa.

Todas as variáveis armazenadas, para os dois protótipos desenvolvidos, são apresentadas na seção 5.2.3. As variáveis escolhidas para cada perfil comportamental foram definidas a partir dos objetivos que os mesmos possuem. Algumas variáveis podem ser avaliadas global ou individualmente. Por exemplo, o perfil comportamental "Interesse Ambiental" do jogador Proprietário Particular, tem definido como variável para análise "Índice de Poluição do Reservatório", que representa a quantidade de poluição do reservatório gerada por todos os jogadores durante o jogo, sendo uma variável a nível global. Já o perfil comportamental "Interesse Econômico" do mesmo tipo de jogador tem definido como variável a 
"Poupança", que representa a quantidade de dinheiro de cada jogador, sendo uma variável a nível individual.

A Tabela 7 apresenta as variáveis para análise de cada um dos perfis comportamentais definidos.

\begin{tabular}{|c|c|c|}
\hline Papel & Perfil & Variáveis \\
\hline 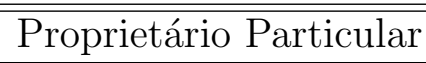 & Econômico & Poupança \\
\hline Proprietário Particular & Ambientalista & Índice Poluição Reservatório \\
\hline AguaPura & Racional & $\begin{array}{l}\text { Índice Poluição Reservatório } \\
\text { Poupança } \\
\text { \% Famílias Conectadas Água } \\
\text { \% Famílias Conectadas Esgoto }\end{array}$ \\
\hline AguaPura & Protetor-Amb. & $\begin{array}{l}\text { Índice Poluição Reservatório } \\
\text { \% Famílias Conectadas Água } \\
\text { \% Famílias Conectadas Esgoto }\end{array}$ \\
\hline Prefeito & Social & $\begin{array}{l}\text { Índice Social Desenvolvimento } \\
\text { \%Pessoas Favela } \\
\text { \% Famílias Conectadas Água } \\
\text { \% Famílias Conectadas Esgoto } \\
\text { \% Desemprego } \\
\text { \% Serviços Urbanos }\end{array}$ \\
\hline Prefeito & Ambientalista & $\begin{array}{l}\text { Índice Social Desenvolvimento } \\
\text { Índice Poluição Reservatório } \\
\text { \% Famílias Conectadas Água } \\
\text { \% Famílias Conectadas Esgoto } \\
\text { Índice Poluição Reservatório }\end{array}$ \\
\hline Prefeito & Econômico & $\begin{array}{l}\text { Índice Social Desenvolvimento } \\
\text { Índice Poluição Reservatório } \\
\text { Poupança } \\
\text { \% Famílias Conectadas Água } \\
\text { \% Famílias Conectadas Esgoto }\end{array}$ \\
\hline SemTeto & Social & $\begin{array}{l}\text { \%Pessoas Favela } \\
\text { \% Famílias Conectadas Água } \\
\text { \% Famílias Conectadas Esgoto }\end{array}$ \\
\hline SemTeto & Econômico & $\begin{array}{l}\text { Poupança } \\
\% \text { Pessoas Favela }\end{array}$ \\
\hline
\end{tabular}

Tabela 7: Perfis Comportamentais e Variáveis.

\subsection{Questionários aos Jogadores Reais}

Os questionários definidos baseiam-se nos questionários originais aplicados aos jogadores no JogoMan, apresentados na seção 5.3.2. Contudo, o ViP-JogoMan será jogado na $W e b$, exigindo dos jogadores conhecimento mínimo de informática. No JogoMan, os jogadores estavam em um mesmo local e as ações escolhidas 
eram anotadas em formulários de papel e entregues a um operador do simulador MABS. Assim, no JogoMan, os jogadores não necessitavam de conhecimento em informática. Já no ViP-JogoMan, todo o processo de negociação e escolha de ações é realizado de forma eletrônica, sendo necessário avaliar este aspecto.

As Tabelas 8 e 9 apresentam os questionários pré e pós-jogo. No questionário pré-jogo, a questão 1 busca definir quais são suas expectativas em participar do jogo. As questões 2 e 3 buscam definir qual o conhecimento em informática dos jogadores, bem como se já jogaram algum RPG na Internet. Já as questões 4 e 5 buscam verificar os conhecimentos específicos em gestão de recursos hídricos e sobre as formas de negociacão nesta área por parte dos jogadores.

No questionário pós-jogo, as questões 1 e 2 buscam verificar se o jogo atendeu as expectativas dos jogadores. A questão 3 tem por objetivo verificar se os jogadores entenderam o jogo e aprenderam algo novo com o mesmo. A questão 4 tem o intuito de verificar se as negociações foram realizadas de forma coerente e satisfatória, ou seja, que os jogadores virtuais conseguiram "trocar" informações de forma satisfatória. As questões 5, 6 e 7 buscam verificar se houve algum tipo de hierarquia durante o processo de negociação, bem como cada jogador reagiu ao jogo (cooperativa ou competitivamente). A questão 8 está relacionada à Reunião do Comitê de Bacia, ou seja, às negociações coletivas. A questão 9 procura saber como foi a tomada de decisão de cada jogador. Já a questão 10 busca definir quais os principais problemas que ocorreram no jogo, e a questão 11 deseja verificar se os jogadores perceberam se algum dos jogadores eram virtuais ou não.

\begin{tabular}{|l|}
\hline \hline Nome:............................. e-mail:..................... \\
\hline 1. Quais são as suas expectativas para participar nessa sessão de jogo? Explique. \\
\hline 2. Você acessa a Internet quantas vezes por semana? \\
( ) Todos os dias ( ) 2 a 3 vezes por semana ( ) Uma vez por semana \\
( ) Menos de uma vez por semana \\
\hline 3. Você já jogou algum jogo (RPG ou não) via Internet? ( )Sim ( )Não Qual? \\
\hline 4. Na sua opinião quais são os maiores problemas da gestão dos recursos hídricos \\
nas bacias peri-urbanas? Pode especificar. \\
\hline 5. Para você quais são os fatores de sucesso de uma negociação, na área ambiental? \\
\hline \hline
\end{tabular}

Tabela 8: Questionário Pré-Jogo para ViP-JogoMan.

\subsection{Análise de Trocas de Mensagens entre os Jogadores}

Segundo McKersie e Fonstad (MCKERSIE; FOnSTAD, 1997), em negociações realizadas via Internet, todos os dados são armazenados e assim é possível analisá- 


\begin{tabular}{l}
\hline \hline Nome:........................... e-mail................... \\
\hline 1. Que papel você desempenhou durante o jogo? Ficou satisfeito com as suas \\
atuações durante o jogo? Quais eram seus objetivos no jogo, para o papel que \\
desempenhou? Conseguiu atingir esses objetivos? Como? \\
\hline 2. O jogo atendeu as suas expectativas? Por quê? \\
\hline 3. O que você aprendeu de novo no jogo em relação à gestão de recursos hídricos? \\
\hline 4. Em relação as negociações entre os jogadores, houve algum problema? Foi \\
possível negociar com todos os jogadores e de forma ampla? Você achou que a \\
forma de negociação, similar a um "chat", foi satisfatória? \\
\hline 5. Na sua opinião, quem tinha maior poder de negociação? (nome dos jogadores) \\
\hline 6. Que tipo de relação existiu entre os jogadores? (cooperação ou competição) \\
Por quê? \\
\hline 7. O que você aprendeu de novo com a negociação? \\
\hline 8. Durante o jogo, você entendeu o que ia acontecendo, ou seja, sua evolução para o \\
resultado final apresentado? Você achou que as ações coletivas foram positivas? \\
Elas foram seguidas pelos jogadores durante o jogo? \\
\hline 9. Durante o jogo, que tipo de informações você utilizou para tomar suas decisões? \\
\hline 10. Suas maiores dificuldades estavam relacionadas a: \\
( ) Negociação via Internet ( ) Entendimento das regras do jogo \\
( ) Limite de tempo em cada rodada do jogo ( )Tomar decisões. Outras. \\
\hline 11. Este jogo pode ter tido a inclusão de alguns jogadores sintéticos (não humanos). \\
Você percebeu se algum dos jogadores teve comportamento não humano? \\
Qual e por quê? \\
\hline \hline
\end{tabular}

Tabela 9: Questionário Pós-Jogo para o ViP-JogoMan.

los com bastante atenção e entender melhor todo o processo de negociação. Van Es et. al (ES; FRENCH; STELLMAZEK, 2004) afirmam que as negociações via Internet devem ser planejadas de maneira diferente das negociações face a face, pois são técnicas diferentes, que utilizam recursos diferentes. Normalmente, em negociação via Internet, há uma menor necessidade de fornecer explicações aos participantes, pois os manuais são mais completos e os participantes sabem que estão "sozinhos" e devem tentar entender as regras antes do início da negociação, estudando e diminuindo suas dúvidas antes do momento em que as negociações efetivamente se iniciam. Sobre este assunto, Mckersie e Fonstad (MCKERSIE; FONSTAD, 1997) ainda reforçam que os manuais e as instruções precisam ser muito claros, pois são a fonte inicial de pesquisa e análise dos participantes para a negociação. Se os manuais estiverem mal projetados, o processo de negociação pode ser comprometido. Assim, uma das grandes limitações da negociação via Internet é que toda a informação deve estar expressa nos manuais e dados adicionais entregues aos participantes.

Neste trabalho, serão analisadas as trocas de mensagens de todos os jogadores durante os jogos-teste a serem realizados. Esta análise será quantitativa, obser- 
vando o número de propostas realizadas. Dois tipos possíveis de negociações serão analisados:

- Negociações Bilaterais: todas as ações que exigem negociação na Fase 1, definidas na seção 8.3.3.1.

Todas as propostas realizadas durantes as rodadas do jogo serão armazenadas, mesmo aquelas que não tiveram resposta do jogador que recebeu a proposta, ou que foram rejeitadas. Com esta análise, pode-se verificar quais são os jogadores mais atuantes durante o jogo, bem como quais são os objetivos de cada jogador, a partir de suas negociações.

- Negociações Coletivas: negociações realizadas na Fase 2 do jogo, definidas na seção 8.3.3.2 e melhor detalhadas no Anexo D.

Todas as estratégias coletivas propostas, aceitas, rejeitadas ou que tiverem contra-propostas, serão analisadas. Com esta análise, pode-se verificar quais são os maiores interesses de cada de jogador.

\subsection{Considerações Finais}

Este capítulo apresentou as três formas de avaliação utilizadas para os testes realizados neste trabalho: Avaliação dos Perfis Comportamentais, Questionários aos Jogadores Reais e Análise de Troca de Mensagens entre Jogadores. A definição de uma metodologia para avaliação para este trabalho foi necessária, visto que não foram encontrados trabalhos que realizassem a avaliação para GMABS.

A avaliação pode focar em dois aspectos: jogadores (virtuais ou reais) e sistema. A primeira forma de avaliação, através dos perfis comportamentais, tenta avaliar os jogadores virtuais e sua interação com o sistema. A segunda forma de avaliação, através dos questionários aos jogadores reais, tenta avaliar os jogadores reais e sua interação com o sistema e também a sua percepção (ou não) da existência dos jogadores virtuais. A terceira forma de avaliação, através da análise de trocas de mensagens, tenta avaliar a interação entre todos os jogadores, buscando verificar como as negociações ocorreram durante o jogo.

A seguir, apresentam-se de forma detalhada os testes realizados com o protótipo ViP-JogoMan. 


\section{Testes e Avaliação no Protótipo ViP-JogoMan}

Este capítulo tem por objetivo testar e avaliar o protótipo ViP-JogoMan, apresentado no capítulo 8. Três tipos de testes foram realizados com este protótipo:

1. Jogos Exclusivamente com Jogadores Virtuais (JV): têm por objetivo verificar se os perfis comportamentais definidos estão funcionando de forma correta, a partir das variáveis definidas;

2. Jogos Exclusivamente com Jogadores Humanos (JH): têm por objetivo verificar como ocorre a interação dos jogadores com a tecnologia - computador e $W e b$ - e o entendimento das regras do jogo pelos jogadores;

3. Jogos Mistos (JM): têm por objetivo verificar como ocorre a tomada de decisão dos jogadores virtuais na presença de jogadores reais e se a inclusão de jogadores virtuais influencia as negociações entre todos os jogadores.

Em todos os tipos de jogos, foi utilizado um cenário de jogo com 14 jogadores. Três grupos de 14 pessoas realizaram os testes com JH, totalizando 42 pessoas. Já para os JM foram utilizados três grupos de 7 pessoas, totalizando 21 pessoas. Todos os participantes dos JM também foram participantes dos JH. Os testes dos JH e JM foram realizados entre os dias 11 e 14 de dezembro de 2006, de forma totalmente remota, estando os jogadores fisicamente localizados em diversos estados do Brasil (Rio Grande do Sul, São Paulo, Santa Catarina, Paraná, Bahia e Pernambuco) e alguns jogadores no exterior (França e Escócia). O sistema foi executado no servidor HTTP do Laboratório de Técnicas Inteligentes (LTI) da Escola Politécnica da Universidade de São Paulo (EP/USP), em São Paulo. Para cada um dos testes dos JH e JH foram executadas 4 rodadas, com duração de 30 minutos cada, totalizando 2 horas por jogo-teste. As seções 10.1, 10.2 e 10.3 apresentam os testes realizados com JV, JH e JM, respectivamente. As considerações finais deste capítulo encontram-se na seção 10.4. 


\subsection{Jogos Exclusivamente com Jogadores Vir- tuais $(\mathrm{JV})$}

Foram realizados apenas dois jogos-teste com jogadores virtuais, cada um com quatro rodadas, para verificar a eficácia na utilização deste tipo de jogador, a partir dos objetivos propostos para cada tipo de perfil comportamental definido no capítulo 7. É utilizada uma única forma de avaliação para estes testes: análise de variáveis dos perfis comportamentais dos jogadores virtuais, apresentada no capítulo 9.

Como dois papéis do jogo, Administrador da AguaPura e Representante dos SemTeto, têm apenas um jogador por jogo e para estes papéis foram definidos dois perfis comportamentais diferentes, não há necessidade de realizar jogos-teste para testar todas as combinações de perfis comportamentais para estes dois papéis, pois a análise dos perfis é realizada de forma isolada, não dependente dos outros papéis. Deste modo, dois jogos-teste com JV foram suficientes para os propósitos desta verificação.

A análise completa de todos os dados dos dois jogos-teste com JV encontrase no Anexo E. A seguir, apresenta-se a análise resumida dos dois jogos-teste realizados e a avaliação dos perfis comportamentais utilizados.

\subsubsection{Jogos-Teste com JV}

A composição dos perfis comportamentais nos dois jogos-teste realizados é apresentada nas Tabelas 10 e 11.

\begin{tabular}{|l|l|l|l|}
\hline \hline \multicolumn{5}{|c|}{ JV - Jogo-Teste 1 } \\
\hline Papel & Perfil Comp. & Identif. Jogadores & Tipo Jogador \\
\hline Proprietário Particular & Ambientalista & Proprietários 1,3,5,7,9 & Virtual \\
\hline Proprietário Particular & Econômico & Proprietários 2,4,6,8 & Virtual \\
\hline Prefeito & Econômico & Prefeito A & Virtual \\
\hline Prefeito & Ambientalista & Prefeito B & Virtual \\
\hline Prefeito & Social & Prefeito C & Virtual \\
\hline Administrador AguaPura & Racional & AguaPura & Virtual \\
\hline Representante SemTeto & Econômico & SemTeto & Virtual \\
\hline \hline
\end{tabular}

Tabela 10: Composição do Jogo-Teste 1 com JV.

A avaliação dos perfis comportamentais com JV é realizada a partir das variáveis definidas na seção 9.2. A variável a nível global mais importante do jogo é o Índice de Poluição do Reservatório. As Tabelas 12 e 13 apresentam os 


\begin{tabular}{|l|l|l|l|}
\hline \hline \multicolumn{5}{c|}{ JV - Jogo-Teste 2 } \\
\hline Papel & Perfil Comp. & Identif. Jogadores & Tipo Jogador \\
\hline Proprietário Particular & Ambientalista & Proprietários $1,3,5,7,9$ & Virtual \\
\hline Proprietário Particular & Econômico & Proprietários $2,4,6,8$ & Virtual \\
\hline Prefeito & Econômico & Prefeito A & Virtual \\
\hline Prefeito & Ambientalista & Prefeito B & Virtual \\
\hline Prefeito & Social & Prefeito C & Virtual \\
\hline Administrador AguaPura & Prot. Ambient. & AguaPura & Virtual \\
\hline Representante SemTeto & Social & SemTeto & Virtual \\
\hline \hline
\end{tabular}

Tabela 11: Composição do Jogo-Teste 2 com JV.

valores encontrados para esta variável nos dois jogos-teste realizados. Pode-se verificar que nos dois jogos-teste realizados, da primeira para a segunda rodada o índice aumentou muito (de 4.800 para $6.343,44$ ), devido a diversas ações tomadas pelos jogadores com perfil comportamental com interesse econômico. A partir da terceira rodada, este índice continuou crescendo, mas de forma controlada, devido à ações do Prefeito com perfil ambientalista. Um aspecto que impediu que a redução da poluição ocorresse de forma mais conclusiva no jogo-teste 1 foi o fato de que o Representante dos SemTeto visou o lucro e instalou famílias em favelas, sem infra-estruturas básicas, conforme mostra a Tabela 14. Já para o segundo jogo-teste, pode-se verificar que o valor final é inferior ao do primeiro jogo-teste, principalmente pelas ações do Representante dos SemTeto, que tem um perfil com interesse social, não alocando famílias em favelas, conforme mostra a Tabela 15.

\begin{tabular}{|l|r|}
\hline \hline \multicolumn{3}{|c|}{ JV - Jogo-Teste 1 } \\
\hline Rodada & Índice de Poluição do Reservatório \\
\hline \hline Rodada 1 & $4.800,00$ \\
\hline Rodada 2 & $6.343,44$ \\
\hline Rodada 3 & $7.180,87$ \\
\hline Rodada 4 & $7.926,94$ \\
\hline \hline
\end{tabular}

Tabela 12: Poluição Global do Reservatório no Jogo-Teste 1 com JV.

\begin{tabular}{|l|r|}
\hline \hline \multicolumn{2}{|c|}{ JV - Jogo-Teste 2 } \\
\hline Rodada & Índice de Poluição do Reservatório \\
\hline \hline Rodada 1 & $4.800,00$ \\
\hline Rodada 2 & $6.343,44$ \\
\hline Rodada 3 & $7.277,10$ \\
\hline Rodada 4 & $7.795,47$ \\
\hline \hline
\end{tabular}

Tabela 13: Poluição Global do Reservatório no Jogo-Teste 2 com JV. 


\begin{tabular}{|l|r|}
\hline \hline \multicolumn{2}{|c|}{ JV - Jogo-Teste 1 } \\
\hline Rodada & \% Moradores em Favelas \\
\hline \hline Rodada 1 & 0.0 \\
\hline Rodada 2 & 0.0 \\
\hline Rodada 3 & 0.0586510 \\
\hline Rodada 4 & 0.0554017 \\
\hline \hline
\end{tabular}

Tabela 14: Percentual de Famílias Morando em Favelas no Jogo-Teste 1 com JV.

\begin{tabular}{|l|r|}
\hline \hline \multicolumn{2}{|c|}{ JV - Jogo-Teste 2 } \\
\hline Rodada & \% Moradores em Favelas \\
\hline \hline Rodada 1 & 0.0 \\
\hline Rodada 2 & 0.0 \\
\hline Rodada 3 & 0.0 \\
\hline Rodada 4 & 0.0 \\
\hline \hline
\end{tabular}

Tabela 15: Percentual de Famílias Morando em Favelas no Jogo-Teste 2 com JV.

por município. As Tabelas 16 e 17 apresentam os valores encontrados para esta variável. No município onde o jogador no papel de Prefeito tem um perfil comportamental com interesse econômico (Prefeito A), o percentual de desemprego é superior, pois não há preocupação com esta variável nos objetivos definidos para este perfil. Mesmo tendo o maior percentual de desemprego, o Prefeito A teve uma variação grande entre os dois jogos-teste, pois no primeiro, o percentual ao final da quarta rodada é de 0,299423 e no segundo jogo-teste, ao final da quarta rodada, é de 0,118785. Essa variação deve-se, principalmente, às ações do Representante dos SemTeto nos dois jogos-teste. No primeiro, o Representante dos SemTeto tem um perfil comportamental com interesse econômico e aloca as famílias em favelas e sem preocupação com a situação social, incluindo número de empregos disponíveis. Já no segundo jogo-teste, este jogador tem um perfil comportamental com interesse social e aloca as famílias em melhores situações, onde haja infra-estrutura de água e de esgoto e com empregos disponíveis.

\begin{tabular}{|l|r|r|r|}
\hline \hline \multicolumn{4}{|c|}{ JV - Jogo-Teste 1 } \\
\hline Rodada & \multicolumn{2}{|c|}{ \% Desemprego por Município } \\
\hline & Município A & Município B & Município C \\
\hline \hline Rodada 1 & 0,100000 & 0,000000 & 0,000000 \\
\hline Rodada 2 & 0,197347 & 0,011111 & 0,075000 \\
\hline Rodada 3 & 0,267722 & 0,000000 & 0,075000 \\
\hline Rodada 4 & 0,299423 & 0,104762 & 0,075000 \\
\hline \hline
\end{tabular}

Tabela 16: Percentual de Desemprego por Município no Jogo-Teste 1 com JV. 


\begin{tabular}{|l|r|r|r|}
\hline \hline \multicolumn{4}{|c|}{ JV - Jogo-Teste 2 } \\
\hline Rodada & \multicolumn{2}{|c|}{ \% Desemprego por Município } \\
\hline & Município A & Município B & Município C \\
\hline \hline Rodada 1 & 0,100000 & 0,000000 & 0,000000 \\
\hline Rodada 2 & 0,118785 & 0,036111 & 0,052778 \\
\hline Rodada 3 & 0,118785 & 0,019444 & 0,044444 \\
\hline Rodada 4 & 0,118785 & 0,019444 & 0,044444 \\
\hline \hline
\end{tabular}

Tabela 17: Percentual de Desemprego por Município no Jogo-Teste 2 com JV.

\subsubsection{Análise dos Jogos-Teste com JV}

Pelos testes realizados, conclui-se que os perfis comportamentais definidos funcionam de forma correta, a partir da análise das variáveis definidas para cada perfil comportamental. Por exemplo, a variável Percentual de Famílias Morando em Favelas, apresentada pelas Tabelas 14 e 15, sofre enormes alterações do jogoteste 1 para o 2, pois o jogador no papel de Representante dos SemTeto assumiu perfis comportamentais diferentes nos dois jogos-teste.

Com a mudança de dois perfis comportamentais do jogo-teste 1 para o 2, os valores das variáveis analisadas foram alterados de forma conclusiva, mostrando que, dependendo do objetivo proposto para o perfil comportamental, suas ações influenciam os resultados globais do jogo.

Os primeiros resultados dos testes realizados com os jogadores virtuais, com Jogos com jogadores exclusivamente virtuais foram apresentados em (ADAMATTI; SICHMAN; COELHO, 2006; ADAMATTI; SICHMAN; COELHO, 2007d; ADAMATTI; SICHMAN; COELHO, 2007e).

\subsection{Jogos Exclusivamente com Jogadores $\mathrm{Hu}-$ $\operatorname{manos}(\mathrm{JH})$}

Os Jogos Exclusivamente com Jogadores Humanos (JH) foram realizados de forma remota, via Web. Foi utilizado o cenário com 14 jogadores, o que envolveu um total de 42 pessoas para os três jogos-teste.

O objetivo destes testes é verificar como ocorre a interação dos jogadores com a tecnologia (computador) e o entendimento das regras do jogo pelos jogadores.

São utilizadas duas formas de avaliação destes testes: questionários pré e pósjogo e análise de troca de mensagens durante o jogo, apresentadas no capítulo 9. A análise completa de todos os dados dos três jogos-teste somente com jogadores 
humanos encontram-se no Anexo E.

\subsubsection{Jogo-Teste 1 com JH}

\subsubsection{Análise das Respostas Fornecidas pelos Jogadores nos Ques- tionários Pré e Pós-Jogo}

Pelas respostas dos jogadores aos questionários pré-jogo, conclui-se que os jogadores tinham boas expectativas em relação ao jogo e que tinham conhecimentos sobre os problemas relacionados à gestão de recursos hídricos. Também se conclui que os jogadores eram experientes quanto ao uso da Internet e inexperientes quanto a jogos do tipo RPG.

Já pelas respostas dadas nos questionários pós-jogo, quatro aspectos podem ser analisados:

1. Avaliação do jogo: os jogadores gostaram do jogo e este atendeu às expectativas, havendo sugestões de melhorias, principalmente relacionadas à interface;

2. Análise do jogo: os jogadores concluíram que a relação existente entre os jogadores durante o jogo foi de competição. Os jogadores ressaltaram que a colaboração é fator decisivo para que mudanças aconteçam e que a comunicação é a chave para haver negociação;

3. Uso da ferramenta: os jogadores reclamaram da grande quantidade de mensagens enviadas/recebidas e da dificuldade de gerenciar/analisar esta grande quantidade de dados. Também sugeriram um chat com mensagens abertas ou uma maior opção de respostas no chat fechado;

4. Existência de jogadores virtuais: nenhum jogador percebeu jogadores virtuais no jogo.

Grande parte dos jogadores afirmou que estava ansiosa para jogar novamente, o que mostra a motivação dos jogadores em relação ao jogo.

\subsubsection{Análise da Troca de Mensagens}

\section{a) Negociações Bilaterais}

A Tabela 18 apresenta as negociações bilaterais para compra/aluguel de lotes da rodada 1 do jogo-teste 1 com JH. Esta tabela apresenta os dados das negociações bilaterais para compra/aluguel de lotes de forma resumida, baseada no 
protocolo de negociação definido para esta ação no capítulo 8. Para um melhor entendimento, a título de exemplo, a explicação ampliada para a negociação número 8, que foi a única negociação de compra concluída na rodada:

- Prefeito C propõe comprar o lote 59 do Proprietário Particular 6, pelo valor de 1.000. O Proprietário Particular 6 solicita contra-proposta de 1.200, e Prefeito C aceita. Assim o Proprietário Particular 6 vende o lote 59 ao Prefeito $\mathrm{C}$ por este valor.

\begin{tabular}{|c|c|c|c|c|c|}
\hline \hline \multicolumn{7}{|c|}{ JH - Jogo-Teste 1 - Rodada 1 } \\
\hline & Comprador & Vendedor & Tipo & Lote & Valor \\
\hline \hline 1 & AguaPura & Proprietário1 & propose & 1 & 1.000 \\
\hline 2 & AguaPura & Proprietário1 & propose & 20 & 1.000 \\
\hline 3 & AguaPura & Proprietário2 & propose & 2 & 1.000 \\
\hline 4 & AguaPura & Proprietário2 & propose & 22 & 1.000 \\
& AguaPura & Proprietário2 & request & 22 & 40.000 \\
& AguaPura & Proprietário2 & propose & 22 & 2.500 \\
& AguaPura & Proprietário2 & request & 22 & 30.000 \\
& AguaPura & Proprietário2 & propose & 22 & 2.500 \\
\hline 5 & Proprietário6 & Proprietário4 & propose & 43 & 1.000 \\
\hline 6 & Proprietário6 & Proprietário5 & propose & 42 & 1.000 \\
\hline 7 & Proprietário6 & Proprietário5 & propose & 49 & 1.000 \\
\hline 8 & PrefeitoC & Proprietário6 & propose & 59 & 1.000 \\
& PrefeitoC & Proprietário6 & request & 59 & 1.200 \\
& PrefeitoC & Proprietário6 & accept_proposal & 59 & 1.200 \\
\hline 9 & PrefeitoC & Proprietário6 & propose & 52 & 1.000 \\
& PrefeitoC & Proprietário6 & request & 52 & 3.000 \\
& PrefeitoC & Proprietário6 & propose & 52 & 1.500 \\
\hline 10 & Proprietário2 & Proprietário8 & rent & 46 & 500 \\
\hline \hline
\end{tabular}

Tabela 18: Negociações Bilaterais de Compra/Aluguel no Jogo-Teste 1 com JH na Rodada 1.

A Tabela 19 apresenta as negociações bilaterais para solicitação de infraestrutura, também de forma resumida. Para um melhor entendimento dos dados apresentados, a primeira solicitação de infra-estrutura significa que o Proprietário Particular 1 solicita água no lote 19 para o Prefeito A, que não respondeu à sua proposta.

Considerando as negociações bilaterais para solicitação de infra-estrutura, em todos os jogos-teste realizados com JH e JM, os jogadores que receberam as solicitações (Prefeitos ou Administrador da AguaPura) não responderam aos jogadores solicitantes (normalmente Proprietários Particulares) sobre a implantação ou não da infra-estrutura solicitada. Estas solicitações são consideradas, perante 
o protocolo de negociação definido na seção 8.3.3.1, como não concluídas. Contudo, é importante analisar este tipo de negociação bilateral, para entender os objetivos dos jogadores que solicitam as infra-estruturas.

\begin{tabular}{|c|c|c|c|c|}
\hline \hline \multicolumn{5}{|c|}{ JH - Jogo-Teste 1 - Rodada 1 } \\
\hline & Prefeito & Quem solicita & Tipo & Lote \\
\hline \hline 1 & PrefeitoA & Proprietário1 & need_water & 19 \\
\hline 2 & PrefeitoA & Proprietário2 & need_water & 6 \\
\hline 3 & PrefeitoB & Proprietário2 & need_hospital & 6 \\
\hline 4 & PrefeitoB & Proprietário6 & need_water & 58 \\
\hline 5 & PrefeitoC & Proprietário6 & need_water & 57 \\
\hline 6 & PrefeitoC & Proprietário6 & need_water & 58 \\
\hline
\end{tabular}

Tabela 19: Negociações Bilaterais de Infra-estrutura no Jogo-Teste 1 com JH na Rodada 1.

Verifica-se que o número de negociações bilaterais realizadas pelos jogadores foi alto, se comparado com as negociações realizadas nos testes do protótipo JogoMan e apresentadas no Anexo B. No caso de compra/aluguel, alguns jogadores tiveram maior interação, como o Administrador da AguaPura e os Prefeitos B e C. Para as solicitações de infra-estrutura, a maior preocupação dos Proprietários Particulares foi a solicitação de infra-estruturas básicas (água e esgoto).

\section{b) Negociações Coletivas}

A Tabela 20 apresenta todas as negociações coletivas realizadas na rodada 1 do jogo-teste 1 com $\mathrm{JH}^{1}$. Os dados nesta tabela são apresentados de forma resumida. Para um melhor entendimento dos dados apresentados, a primeira estratégia coletiva (Ampliar rede de água) foi:

- Proposta pelos jogadores: Proprietários Particulares 1 e 2 e pelo administrador da AguaPura;

- Aceita pelos jogadores: Proprietários Particulares 1,6 e 8 e pelo Prefeito C.

- Rejeitada: por nenhum jogador;

- Realizada Contra-Proposta: por nenhum jogador.

\footnotetext{
${ }^{1}$ Legenda: Proprietários de 1 a 9: denominados pelos números de 1 a 9; Prefeitos A, B ou C: denominados pelas letras A,B ou C; Representante dos SemTeto: denominado pelas letras ST; Administrador da AguaPura: denominado pelas letras AP; C-Proposta: Contra-Proposta. Esta legenda será adotada em todas as tabelas deste tipo, presentes neste capítulo.
} 


\begin{tabular}{|l|c|c|c|c|}
\hline \hline \multicolumn{6}{|c|}{ JH - Jogo-Teste 1 - Rodada 1 } \\
\hline Estratégia & Propor & Aceitar & Rejeitar & C-Proposta \\
\hline \hline 1 - Ampliar rede de água & $1,2, \mathrm{AP}$ & $1,6,8, \mathrm{C}$ & & \\
\hline 2 - Ampliar rede de esgoto & $2,6, \mathrm{AP}$ & $2, \mathrm{C}$ & & 8 \\
\hline $\begin{array}{l}\text { 3 - Delimitar a área urbana de } \\
\text { meu município: Lotes 54, 62 }\end{array}$ & 6 & & & 2 (Lote 23) \\
\hline $\begin{array}{l}\text { 6 - Ações que incentivam o uso } \\
\text { da área rural de meu município }\end{array}$ & 8 & $1,2,6,8, \mathrm{C}$ & & \\
\hline \hline
\end{tabular}

Tabela 20: Negociações Coletivas no Jogo-Teste 1 com JH na Rodada 1.

Pela Tabela 20, as estratégias coletivas mais negociadas foram as solicitações de infra-estruturas, onde os jogadores propuseram e negociaram mais sobre as estratégias coletivas 1 (Ampliar a rede de água) e 2 (Ampliar a rede de esgoto). Pelas estratégias coletivas, pode-se verificar que muitos Proprietários Particulares tinham preocupação com a preservação da área rural (estratégia 6 - Ações que incentivam o uso da área rural de meu município), o que contradiz as informações dos questionários pós-jogo, onde os jogadores afirmaram que os Proprietários Particulares tinham interesses econômicos e no jogo as atividades rurais não são as mais lucrativas.

Um aspecto interessante a ser analisado nas negociações coletivas é a verificação, por parte dos jogadores, do cumprimento das estratégias coletivas definidas na "Reunião do Comitê de Bacia" em rodadas posteriores. Segundo a Tabela 20, na primeira rodada, o Prefeito $\mathrm{C}$ aceitou as estratégias: 1 - Ampliar rede de água, 2 - Ampliar rede de esgoto e 6 - Ações que incentivam o uso da área rural do meu município. Pela Tabela 21, na segunda rodada de jogo, o Prefeito C instalou rede de esgoto nos lotes 60 e 61, cumprindo a estratégia 2, anteriormente negociada. Também reduziu os impostos para uso do solo Floresta para $\mathrm{R} \$ 0,00$, tentando incentivar este tipo de uso, e cumprindo a estratégia 6. Já o Administrador da AguaPura, que apenas propôs as estratégias 1 e 2, não realizou nenhuma ação com intuito de cumprí-las em rodadas posteriores, pois não instalou a infra-estrutura de água ou de esgoto em nenhum lote durante o jogo. As Tabelas 21, 22 e 23 apresentam a aplicação das estratégias coletivas discutidas pelos jogadores em rodadas posteriores. A quarta rodada não é apresentada, pois sendo a última, é impossível verificar se as estratégias coletivas negociadas foram ou não cumpridas pelos jogadores. Pode-se verificar que apenas alguns jogadores cumpriram as negociações coletivas firmadas. De fato, neste primeiro jogo-teste, dentre os papéis que possuem poder para alterar o coletivo (Prefeitos e Administrador da AguaPura), apenas os jogadores nos papéis de Prefeito B e Prefeito C cumpriram o que foi firmado durante as negociações coletivas. Tanto o Administrador da 
AguaPura quanto o Prefeito A não executaram ações referentes às estratégias coletivas negociadas.

\begin{tabular}{|l|c|c|}
\hline \hline \multicolumn{3}{|c|}{ JH - Jogo-Teste 1 - Rodada 1 } \\
\hline Estratégia & Jogador Aceitou & Ações Executadas Post. \\
\hline \hline 1 - Ampliar rede de água & $\mathrm{C}$ & \\
\hline 2 - Ampliar rede de esgoto & $\mathrm{C}$ & Esgoto em lotes 60 e 61 \\
\hline $\begin{array}{l}\text { 6 - Ações que incentivam o uso } \\
\text { da área rural de meu município }\end{array}$ & $\mathrm{C}$ & Redução Imposto Floresta \\
\hline
\end{tabular}

Tabela 21: Estratégias Coletivas Aceitas na Rodada 1 e Ações Executadas em Rodadas Posteriores no Jogo-Teste 1 com JH.

\begin{tabular}{|l|c|c|}
\hline \hline \multicolumn{3}{|c|}{ JH - Jogo-Teste 1 - Rodada 2 } \\
\hline Estratégia & Jogador Aceitou & Ações Executadas Post. \\
\hline \hline 1 - Ampliar rede de água & AP & \\
\hline 2 - Ampliar rede de esgoto & B & Esgoto em lotes 32 e 40 \\
\hline
\end{tabular}

Tabela 22: Estratégias Coletivas Aceitas na Rodada 2 e Ações Executadas em Rodadas Posteriores no Jogo-Teste 1 com JH.

\begin{tabular}{|l|c|c|}
\hline \hline \multicolumn{3}{|c|}{ JH - Jogo-Teste 1 - Rodada 3 } \\
\hline Estratégia & Jogador Aceitou & Ações Executadas Post. \\
\hline \hline 2 - Ampliar rede de esgoto & AP & \\
\hline $\begin{array}{l}\text { 10 - Limitar áreas residenciais } \\
\text { para Sem Teto }\end{array}$ & B & Venda de lote ao SemTeto \\
\hline \hline
\end{tabular}

Tabela 23: Estratégias Coletivas Aceitas na Rodada 3 e Ações Executadas em Rodadas Posteriores no Jogo-Teste 1 com JH.

Pela quantidade de troca de mensagens pelos jogadores pode-se concluir que a interação entre os jogadores ocorreu de forma ampla, tendo alguns jogadores interagido mais que outros, o que ocorre também com Jogos de mesa. Uma possível explicação para isso, segundo Peppet (PEPPET, 2002), é o fato de que participantes em negociações via Internet normalmente sentem-se mais a vontade para interagir com os outros jogadores do que face a face, pois não há problemas de inibição, preconceitos, etc, e a negociação é muito mais transparente e direta.

\subsubsection{Jogo-Teste 2 com JH}

No segundo jogo-teste com JH aconteceram apenas três rodadas, pois houve um problema no momento de computar as ações dos jogadores na terceira rodada, quando o simulador Cormas travou devido a problemas de programação para uma ação dos Proprietários Particulares em relação ao aluguel. No primeiro jogoteste não houve esse problema, pois essa ação não foi executada por nenhum dos 
jogadores. Contudo, os dados obtidos foram suficientes para realizar a análise. Para os jogos-teste seguintes, tal problema foi sanado.

\subsubsection{Análise das Respostas Fornecidas pelos Jogadores nos Ques- tionários Pré e Pós-Jogo}

Pelas respostas dos jogadores aos questionários pré-jogo conclui-se que os jogadores tinham boas expectativas em relação ao jogo, buscando diversão e novos conhecimentos, e que tinham conhecimentos sobre os problemas relacionados a gestão de recursos hídricos. Também se conclui que os jogadores eram experientes quanto ao uso da Internet e que metade dos jogadores já havia jogado jogos via Internet, inclusive RPGs e a outra metade era inexperiente em relação a este tipo de jogo.

Já pelas respostas dadas nos questionários pós-jogo, foram analisados quatro aspectos:

1. Avaliação do jogo: os jogadores ficaram satisfeitos com o jogo, pois entenderam seu funcionamento e suas regras, atendendo a suas expectativas. Foram feitas sugestões para melhorar a interface, a comunicação entre os jogadores e dar mais tempo em cada rodada para os jogadores escolherem suas ações e negociarem;

2. Análise do jogo: os jogadores concluíram que a relação existente entre os jogadores durante o jogo foi de cooperação, diferentemente do jogo-teste anterior, onde a relação apontada entre os jogadores foi de competição. Os jogadores ressaltaram que a comunicação é vital para haver negociação;

3. Uso da ferramenta: os jogadores reclamaram da grande quantidade de mensagens enviadas/recebidas e da dificuldade de gerenciamento. Também sugeriram um chat com mensagens abertas ou com maior opção de respostas, para atender melhor às possíveis respostas e também sugeriram aumentar o tempo por rodada;

4. Existência de jogadores virtuais: um jogador achou que um outro era virtual, pois escolhia suas ações e jogava muito rápido.

Novamente, grande parte dos jogadores estava ansiosa para jogar novamente, mostrando a motivação em relação ao jogo. 


\subsubsection{Análise da Troca de Mensagens}

\section{a) Negociações Bilaterais}

A Tabela 24 apresenta as propostas de compra/aluguel de lotes e a Tabela 25 apresenta as solicitações de infra-estrutura dos jogadores para a rodada 1 do jogo-teste 2 .

\begin{tabular}{|c|c|c|c|c|c|}
\hline \hline \multicolumn{7}{|c|}{ JH - Jogo-Teste 2 - Rodada 1 } \\
\hline & Comprador & Vendedor & Tipo & Lote & Valor \\
\hline \hline 1 & AguaPura & Proprietário7 & propose & 45 & 2.500 \\
\hline 2 & AguaPura & Proprietário2 & propose & 14 & 10.000 \\
\hline 3 & SemTeto & Proprietário1 & propose & 3 & 100 \\
\hline 4 & PrefeitoB & Proprietário9 & propose & 39 & 2.000 \\
\hline 5 & SemTeto & Proprietário8 & propose & 45 & 500 \\
\hline 6 & PrefeitoC & Proprietário8 & propose & 45 & 500 \\
& PrefeitoC & Proprietário8 & request & 45 & 700 \\
& PrefeitoC & Proprietário8 & propose & 45 & 680 \\
\hline \hline
\end{tabular}

Tabela 24: Negociações Bilaterais de Compra/Aluguel no Jogo-Teste 2 com JH na Rodada 1.

\begin{tabular}{|c|c|c|c|c|}
\hline \hline \multicolumn{5}{|c|}{ JH - Jogo-Teste 2 - Rodada 1 } \\
\hline & Prefeito & Quem solicita & Tipo & Lote \\
\hline \hline 1 & PrefeitoB & AguaPura & need_sanitation & 30 \\
\hline 2 & PrefeitoB & Proprietário2 & need_water & 23 \\
\hline 3 & PrefeitoB & Proprietário2 & need_sanitation & 23 \\
\hline 4 & PrefeitoC & AguaPura & need_sanitation & 45 \\
\hline \hline
\end{tabular}

Tabela 25: Negociações Bilaterais de Infra-estrutura no Jogo-Teste 2 com JH na Rodada 1.

Pela Tabela 24, verifica-se que este jogo-teste teve um número menor de interações entres os jogadores do que o jogo-teste 1 com JH, realizando uma comparação das três primeiras rodadas de ambos os jogos-teste para as propostas de compra/aluguel de lotes. Pela Tabela 25, verifica-se que os jogadores solicitaram apenas infra-estruturas básicas (água e esgoto).

\section{b) Negociações Coletivas}

A Tabela 26 apresenta as estratégias coletivas negociadas na rodada 1 do jogo-teste 2 com JH.

A Tabela 26 mostra que as estratégias coletivas mais negociadas foram as solicitações de infra-estrutura, através das estratégias 1 (Ampliar rede de água) e 2 (Ampliar rede de esgoto). 


\begin{tabular}{|l|c|c|c|c|}
\hline \hline \multicolumn{5}{|c|}{ JH - Jogo-Teste 2 - Rodada 1 } \\
\hline Estratégia & Propor & Aceitar & Rejeitar & C-Proposta \\
\hline \hline 1 - Ampliar rede de água & $3, \mathrm{~B}$ & $2,6,7, \mathrm{~B}$ & $\mathrm{AP}$ & \\
\hline 2 - Ampliar rede de esgoto & $2,8, \mathrm{C}$ & 6 & $\mathrm{AP}$ & \\
\hline $\begin{array}{l}\text { 3 - Delimitar a área urbana de } \\
\text { meu município: Lotes 45,46,47,48 }\end{array}$ & 9 & 9 & & 2 (Lotes 22,23,24) \\
\hline $\begin{array}{l}4 \text { - Ações que incentivam o uso da } \\
\text { área urbana de meu município }\end{array}$ & $2, \mathrm{C}$ & 8 & & \\
\hline $\begin{array}{l}\text { 5 - Delimitar a área rural de } \\
\text { meu município: } \\
\text { Lotes 3,4,5,6,11,14,19 }\end{array}$ & & & & \\
\hline $\begin{array}{l}\text { 6 - Ações que incentivam o uso } \\
\text { da área rural de meu município }\end{array}$ & 9 & 7 & & \\
\hline $\begin{array}{l}\text { 7 - Insenção gradual de impostos } \\
\text { aos menos poluentes }\end{array}$ & B,C & 7,9 & & \\
\hline $\begin{array}{l}\text { 8 - Prefeitos auxiliam os } \\
\text { Sem Teto }\end{array}$ & B,C,ST & 6 & & \\
\hline $\begin{array}{l}\text { 10 - Limitar áreas residenciais } \\
\text { para Sem Teto }\end{array}$ & C & & & \\
\hline \hline
\end{tabular}

Tabela 26: Negociações Coletivas no Jogo-Teste 2 com JH na Rodada 1.

Em relação às estratégias aceitas pelos jogadores que podem alterar o coletivo e cumpridas em rodadas posteriores, as Tabelas 27 e 28 apresentam as ações executadas com intuito de efetivar as estratégias negociadas. Observa-se que apenas o jogador no papel de Prefeito B aceitou e cumpriu as estratégias coletivas negociadas. Na rodada 1, o Prefeito B aceitou a estratégia coletiva 1 - Ampliar rede de água e na rodada seguinte instalou infra-estrutura de água nos lotes 30 e 39. Como este jogo-teste teve apenas três rodadas, a análise das ações relacionadas as estratégias coletivas ocorreu apenas até a segunda rodada coletiva.

\begin{tabular}{|l|c|c|}
\hline \hline \multicolumn{3}{|c|}{ JH - Jogo-Teste 2 - Rodada 1 } \\
\hline Estratégia & Jogador Aceitou & Ações Executadas Post. \\
\hline \hline 1 - Ampliar rede de água & B & Água em lotes 30 e 39 \\
\hline \hline
\end{tabular}

Tabela 27: Estratégias Coletivas Aceitas na Rodada 1 e Ações Executadas em Rodadas Posteriores no Jogo-Teste 2.

\begin{tabular}{|l|c|c|}
\hline \hline \multicolumn{2}{|c|}{ JH - Jogo-Teste 2 - Rodada 2 } \\
\hline Estratégia & Jogador Aceitou & Ações Executadas Post. \\
\hline \hline 1 - Ampliar rede de água & B & Água em lote 38 \\
\hline $\begin{array}{l}\text { 8 - Prefeitos auxiliam os } \\
\text { Sem Teto }\end{array}$ & B & Esgoto em lote 38 (invadido) \\
\hline \hline
\end{tabular}

Tabela 28: Estratégias Coletivas Aceitas na Rodada 2 e Ações Executadas em Rodadas Posteriores no Jogo-Teste 2. 
Tanto para as negociações bilaterais quanto para as coletivas, alguns jogadores interagiram mais que outros. Uma possível explicação para este fato pode ser um problema de entendimento das regras do jogo por alguns jogadores, fazendo com que os mesmos não pudessem interagir de forma ampla.

\subsubsection{Jogo-Teste 3 com JH}

\subsubsection{Análise das Respostas Fornecidas pelos Jogadores nos Ques- tionários Pré e Pós-Jogo}

Pelas respostas dos jogadores aos questionários pré-jogo conclui-se que os jogadores gostariam de aprender mais sobre o domínio do problema e que tinham conhecimentos sobre os problemas relacionados à gestão de recursos hídricos. Também se conclui que os jogadores eram experientes quanto ao uso da Internet e quanto a jogos do tipo RPG ou jogos via Internet. Este grupo de jogadores, comparativamente aos jogadores dos jogos-teste 1 e 2 , era o mais experiente em relação a jogos do tipo RPG e/ou jogos via Internet.

Os quatro aspectos analisados pelas respostas dos jogadores nos questionários pós-jogo foram:

1. Avaliação do jogo: os jogadores não ficaram satisfeitos com o jogo, pois não conseguiram atingir os objetivos que se propuseram. Contudo, acharam que o jogo atendeu às expectativas iniciais;

2. Análise do jogo: os jogadores concluíram que a relação existente entre os jogadores durante o jogo foi de competição. Os jogadores concluíram que a gestão de recursos hídricos é um problema de todos e que a execução de ações individuais, sem pensar no conjunto, não ajuda na melhoria da qualidade ambiental, nem no processo de negociação;

3. Uso da ferramenta: os jogadores acharam que as negociações ocorreram de forma ampla e clara, mas gostariam de um chat com mensagens abertas. Este grupo de jogadores foi o único que não reclamou da quantidade de mensagens recebidas/enviadas entre os jogadores. Uma possível resposta para isso é a maior experiência com Jogos deste tipo;

4. Existência de jogadores virtuais: dois jogadores acharam que outros dois jogadores era virtuais, pois agiram de forma muito "correta", executando ações voltadas ao bem estar de todos, ou porque as ações foram escolhidas muito rapidamente durante o jogo. 
Novamente, vários jogadores comentaram que gostariam de participar de uma nova sessão do jogo, mostrando-se bastante motivados.

\subsubsection{Análise da Troca de Mensagens}

\section{a) Negociações Bilaterais}

A Tabela 29 apresenta as propostas de compra/aluguel de lotes dos jogadores na rodada 1 do jogo-teste 3 . A Tabela 30 apresenta as solicitações de infraestrutura dos jogadores para a rodada 2 do jogo-teste 3 , visto que na rodada 1 não foram realizadas negociações deste tipo. Já as Tabelas 31 e 32 apresentam as ações específicas do Representante dos SemTeto para com os outros jogadores. Este tipo de negociação não foi utilizada pelos jogadores no papel de Representante dos SemTeto nos jogos-teste 1 e 2, aparecendo agora pela primeira vez.

\begin{tabular}{|c|c|c|c|c|c|}
\hline \hline \multicolumn{7}{|c|}{ JH - Jogo-Teste 3 - Rodada 1 } \\
\hline & Comprador & Vendedor & Tipo & Lote & Valor \\
\hline \hline 1 & Proprietário2 & Proprietário3 & propose & 7 & 500 \\
\hline 2 & Proprietário8 & Proprietário7 & propose & 55 & 1.000 \\
\hline 3 & PrefeitoC & Proprietário6 & propose & 59 & 1.500 \\
\hline 4 & PrefeitoC & Proprietário6 & propose & 52 & 1.500 \\
& PrefeitoC & Proprietário6 & request & 52 & 3.000 \\
& PrefeitoC & Proprietário6 & propose & 52 & 2.000 \\
\hline 5 & PrefeitoC & Proprietário7 & propose & 54 & 1.500 \\
\hline 6 & PrefeitoC & Proprietário7 & propose & 62 & 1.500 \\
\hline 7 & Proprietário4 & Proprietário1 & propose & 28 & 800 \\
\hline 8 & Proprietário4 & Proprietário5 & propose & 34 & 800 \\
\hline 9 & Proprietário7 & Proprietário8 & propose & 56 & 1.000 \\
\hline \hline
\end{tabular}

Tabela 29: Negociações Bilaterais de Compra/Aluguel no Jogo-Teste 3 com JH na Rodada 1.

\begin{tabular}{|c|c|c|c|c|}
\hline \hline \multicolumn{5}{|c|}{ JH - Jogo-Teste 3 - Rodada 2 } \\
\hline & Prefeito & Quem solicita & Tipo & Lote \\
\hline \hline 1 & PrefeitoB & AguaPura & need_sanitation & 29 \\
\hline 2 & PrefeitoB & AguaPura & need_sanitation & 37 \\
\hline
\end{tabular}

Tabela 30: Negociações Bilaterais de Infra-estrutura no Jogo-Teste 3 com JH na Rodada 2.

Pela Tabela 29, verifica-se que os jogadores interagiram com os outros jogadores de forma ampla, pela quantidade de propostas de compra/aluguel realizadas em todas as rodadas. Este número foi superior aos dos JH 1 e 2.

Como já verificado nos dois outros jogos-teste com JH, as solicitações por infra-estrutura priorizaram água e esgoto (Tabela 30). 


\begin{tabular}{|c|c|c|}
\hline \hline \multicolumn{3}{|c|}{ JH - Jogo-Teste 3 - Rodada 2 } \\
\hline & Ação & A quem solicita \\
\hline \hline 1 & search_plots & Proprietários 1,2,4,5,6,7,8 e AguaPura \\
\hline 2 & help & Proprietário2 \\
\hline
\end{tabular}

Tabela 31: Negociações Bilaterais Específicas do Representante dos SemTeto no Jogo-Teste 3 com JH na Rodada 2.

\begin{tabular}{|c|c|c|}
\hline \hline \multicolumn{2}{|c|}{ JH - Jogo-Teste 3 - Rodada 4 } \\
\hline & Ação & A quem solicita \\
\hline \hline 1 & help & Proprietário3 \\
\hline \hline
\end{tabular}

Tabela 32: Negociações Bilaterais Específicas do Representante dos SemTeto no Jogo-Teste 3 com JH na Rodada 4.

As Tabelas 31 e 32 apresentam os dados das negociações bilaterais específicas do Representante dos SemTeto, de forma resumida. Para um melhor entendimento, segue-se a título de exemplo a explicação ampliada para as negociações números 1 e 2 da rodada 2. Na negociação número 1, o Representante dos SemTeto está procurando lotes e envia mensagem aos Proprietários Particulares 1,2,4,5,6,7 e 8 e também ao Administrador da AguaPura, mas não obtém resposta de nenhum destes jogadores. Já na negociação número 2, o Representante solicita ajuda $^{2}$ do Proprietário Particular 2.

\section{b) Negociações Coletivas}

A Tabela 33 apresenta as estratégias coletivas negociadas na rodada 1 do jogo-teste 3 com JH.

Pela Tabela 33, observa-se que a estratégias coletivas mais negociadas neste jogo-teste foram as solicitações de infra-estrutura. Contudo, no Anexo E, onde são apresentados todos os dados dos jogos-teste, pode-se observar também que nas rodadas 2 e 3 deste jogo-teste, os Proprietários Particulares solicitaram a isenção de impostos (Estratégia 7 - Insenção gradual de impostos aos menos poluentes). Esta informação foi colocada pelos jogadores em suas respostas nos questionários pós-jogo ${ }^{3}$, questão 8, onde houve reclamação sobre aumento de impostos por parte dos Proprietário Particulares aos Prefeitos e nas ações coletivas pode-se verificar esse questionamento. Como os Proprietários Particulares não têm poder para alterar os valores de impostos e os Prefeitos, que tinham este poder, não

\footnotetext{
${ }^{2} \mathrm{O}$ tipo de negociação help é uma forma do jogador no papel do Representante dos SemTeto para procurar lotes para alocar novas famílias. Os Prefeitos podem fazer doações de lotes para o Representante dos SemTeto.

${ }^{3}$ Ver as principais respostas dos jogadores no Anexo E.
} 


\begin{tabular}{|l|c|c|c|c|}
\hline \hline \multicolumn{5}{|c|}{ JH - Jogo-Teste 3 - Rodada 1 } \\
\hline Estratégia & Propor & Aceitar & Rejeitar & C-Proposta \\
\hline \hline 1 - Ampliar rede de água & $2,4,8, \mathrm{C}, \mathrm{ST}$ & $4, \mathrm{ST}$ & & \\
\hline 2 - Ampliar rede de esgoto & $8, \mathrm{C}$ & 2,8 & & \\
\hline $\begin{array}{l}\text { 3 - Delimitar a área urbana de } \\
\text { meu município: } \\
\text { Lotes 45,51,52,54,59,62,63 }\end{array}$ & & & & \\
\hline $\begin{array}{l}\text { 6 - Ações que incentivam o uso } \\
\text { da área rural de meu município }\end{array}$ & 4,8 & $7, \mathrm{C}$ & & \\
\hline $\begin{array}{l}\text { 9 - Incentivo a construção de } \\
\text { novas indústrias na região urbana } \\
\text { para geração de empregos }\end{array}$ & & & & \\
\hline \hline
\end{tabular}

Tabela 33: Negociações Coletivas no Jogo-Teste 3 com JH na Rodada 1.

aceitaram e não executaram ações para reduzir impostos, a estratégia 7 continuou sendo um assunto de interesse dos proprietários durante todas as rodadas.

\begin{tabular}{|l|c|c|}
\hline \hline \multicolumn{3}{|c|}{ JH - Jogo-Teste 3 - Rodada 1 } \\
\hline Estratégia & Jogador Aceitou & Ações Executadas Poster. \\
\hline \hline 6 - Ações que incentivam o uso & & \\
da área rural de meu município & $\mathrm{C}$ & Redução Imposto Agricultura \\
\hline \hline
\end{tabular}

Tabela 34: Estratégias Coletivas Aceitas na Rodada 1 e Ações Executadas em Rodadas Posteriores no Jogo-Teste 3.

\begin{tabular}{|l|c|c|}
\hline \hline \multicolumn{3}{|c|}{ JH - Jogo-Teste 3 - Rodada 2 } \\
\hline Estratégia & Jogador Aceitou & Ações Executadas Poster. \\
\hline \hline 2 - Ampliar rede de esgoto & B & \\
\hline
\end{tabular}

Tabela 35: Estratégias Coletivas Aceitas na Rodada 2 e Ações Executadas em Rodadas Posteriores no Jogo-Teste 3.

Em relação às estratégias aceitas pelos jogadores que podem alterar o coletivo e cumpridas em rodadas posteriores, as Tabelas 34, 35 e 36 apresentam as ações executadas com intuito de efetivar as estratégias negociadas. Conforme a Tabela 33, na rodada 1, o Prefeito $\mathrm{C}$ aceitou a estratégia coletiva 6 - Ações que incentivam o uso da área rural de meu município, e na rodada seguinte alterou o valor do imposto para agricultura, como forma de incentivar este tipo de uso do solo, conforme Tabela 34. Outros jogadores aceitaram estratégias coletivas (Prefeito B e Administrador da AguaPura), mas não executaram ações relacionadas as estratégias aceitas, ou seja, não cumpriram o que foi negociado na fase 2 (coletiva). 


\begin{tabular}{|l|c|c|}
\hline \hline \multicolumn{3}{|c|}{ JH - Jogo-Teste 3 - Rodada 3 } \\
\hline Estratégia & Jogador Aceitou & Ações Executadas Poster. \\
\hline \hline 6 - Ações que incentivam o uso & AP & \\
da área rural de meu município & AP \\
\hline
\end{tabular}

Tabela 36: Estratégias Coletivas Aceitas na Rodada 3 e Ações Executadas em Rodadas Posteriores no Jogo-Teste 3.

\subsubsection{Análise dos Jogos-Teste com JH}

A partir dos três jogos-teste com JH, verifica-se que o protótipo ViP-JogoMan ofereceu aos jogadores condições de jogo, proporcionando sensação de interação, divertimento e aprendizagem aos jogadores. Isso pode ser confirmado pelas respostas dos jogadores e pela análise da troca de mensagens tanto para as negociações bilaterais quanto para as negociações coletivas.

Conclui-se também que a utilização da $W e b$ para a metodologia GMABS é eficiente e prática, pois disponibiliza sua utilização de lugares remotos, viabilizando sua utilização por um grupo maior de pessoas. Sendo o principal objetivo da realização de JH verificar se a tecnologia (computador) influencia na interação entre os jogadores, pode-se concluir o computador auxilia na maior utilização deste tipo de jogo.

Os jogadores também propuseram melhorias ao jogo, a partir das respostas dos questionários pós-jogo. As principais melhorias/críticas apresentadas pelos jogadores foram:

- Grande parte dos jogadores sugeriram a utilização de um sistema de chat aberto, onde as justificativas das mensagens pudessem ser digitadas de forma aberta. Alguns sugeriram, que se não fosse possível utilizar um chat aberto, que então fosse ampliado o número de justificativas possíveis no chat fechado;

- Muitos jogadores reclamaram que a fase 1 era muito curta e a fase 2 (coletiva) muito longa. As duas fases tinham a mesma duração (15 minutos cada). Sugeriram que a fase 1 fosse mais longa e a fase 2 mais curta, e também o aumento de rodadas do jogo, para melhor entendimento da evolução global;

- Também relacionado à evolução global, houve reclamação sobre a apresentação das informações globais do jogo. Os jogadores gostariam que todas as informações da região fossem visíveis a todos os jogadores. Nesta 
primeira versão do ViP-JogoMan, que é idêntica em suas regras ao JogoMan, apenas o Administrador da AguaPura tem a visão global de toda a região;

- Muitos jogadores gostariam de um número maior de ferramentas gráficas, principalmente ligado ao envio e ao recebimento de mensagens, para um melhor entendimento.

Relacionado às negociações, tanto ao nível bilateral quanto ao nível coletivo, conclui-se que os jogadores, em todos os jogos-teste, negociaram de forma ampla, o que pode ser comprovado pela quantidade de negociações realizadas. O número de negociações varia em cada jogo-teste, sendo uma restrição relacionada ao grupo de jogadores, que não é homogêneo. Este aspecto não atrapalha em nada a realização dos testes, pois na verdade a heterogeneidade dos jogadores é fator de destaque para que novas formas de negociação aconteçam durante os jogos (ES; FRENCH; STELLMAZEK, 2004).

Nos jogos-teste 2 e 3 com JH, alguns jogadores acharam que outros jogadores pudessem ser virtuais. Nos JH, apenas pessoas participaram dos testes, mas é interessante verificar que alguns jogadores tenham suspeitado da presença de jogadores virtuais. Os motivos expressos pelos jogadores da presença de jogadores virtuais foi a forma que alguns jogadores agiram durante o jogo: ou tendo escolhas ditas "corretas" ou escolhendo suas ações rapidamente. Contudo, estes motivos não representam a real existência de jogadores virtuais nos jogos-teste. Nos próximos jogos-teste, com Jogos mistos, onde jogadores virtuais estarão incluídos nos jogo, será interessante verificar se as pessoas perceberam sua existência e quais serão os motivos expressos para tal percepção.

\subsection{Jogos com Jogadores Mistos (JM)}

Os Jogos com Jogadores Mistos (JM) também foram realizados de forma remota, via Web. Para os três jogos-teste realizados, o cenário com 14 jogadores foi utilizado em cada jogo, sendo 7 jogadores reais (pessoas) e 7 jogadores virtuais nos dois primeiros jogos-teste e 8 jogadores reais e 6 jogadores virtuais no terceiro jogo-teste. Os 7 (8) jogadores reais já haviam participado de uma sessão do jogo-teste com JH. Adicionalmente, nas sessões de jogos-teste com JM, os jogadores reais executaram o mesmo papel que nas seções dos jogos-teste com JH. Como já haviam participado de uma sessão anterior do jogo, os jogadores reais possuíam um maior entendimento das regras do jogo, bem como da interface e 
das formas de negociação entre os jogadores. Esta "adaptação" às regras do jogo e à sua interface é importante para os jogadores reais, pois os jogadores virtuais não têm problemas relacionados com a interação com a tecnologia e têm total conhecimento das regras do jogo, a partir dos perfis comportamentais definidos para tipo de papel.

Os objetivos da realização dos jogos-teste com JM são: i) verificar como ocorre a tomada de decisão dos jogadores virtuais com os jogadores reais; e ii) verificar se a inclusão de jogadores virtuais influencia no processo de negociação entre todos os jogadores.

As configurações de jogadores virtuais utilizadas em cada um dos nos três jogos-teste realizados são diferentes, pois é necessário testar todos os perfis comportamentais definidos.

São utilizadas três formas de avaliação nestes testes: questionários pós-jogo, análise das variáveis de cada perfil comportamental dos jogadores virtuais e análise de troca de mensagens durante o jogo, apresentadas no capítulo 9. A análise completa de todos os dados dos três jogos-teste mistos encontram-se no Anexo E.

\subsubsection{Jogo-Teste 1 com JM}

A composição utilizada para os jogadores no jogo-teste 1 com JM encontra-se na Tabela 37.

\begin{tabular}{|l|c|r|r|}
\hline \hline \multicolumn{5}{|c|}{ JM - Jogo-Teste 1 } \\
\hline Papel & Perfil Comp. & Identif. Jogadores & Tipo Jogador \\
\hline \hline Proprietário Particular & Econômico & Proprietários 3 e 6 & Virtual \\
\hline Proprietário Particular & Ambientalista & Proprietários 8 e 9 & Virtual \\
\hline Proprietário Particular & - & Proprietários 1,2,4,5 e 7 & Real \\
\hline Prefeito & - & Prefeitos A e B & Real \\
\hline Prefeito & Econômico & Prefeito C & Virtual \\
\hline Administrador AguaPura & Protetor-Amb. & AguaPura & Virtual \\
\hline Representante SemTeto & Econômico & SemTeto & Virtual \\
\hline \hline
\end{tabular}

Tabela 37: Composição Papéis e Perfis Comportamentais no Jogo-Teste 1 com JM. 


\subsubsection{Análise das Respostas Fornecidas pelos Jogadores nos Ques- tionários Pós-Jogo}

Das respostas dos jogadores nos questionários pós-jogo foram analisados quatro aspectos:

1. Avaliação do jogo: os jogadores ficaram satisfeitos com o jogo, pois conseguiram atingir seus objetivos e o jogo atendeu as suas expectativas, sendo dinâmico e divertido, dando oportunidade de observar a reação dos outros jogadores frente à colaboração/competição;

2. Análise do jogo: os jogadores acharam que os Prefeitos tiveram uma relação de cooperação e que os Proprietários Particulares uma relação de competição. Também concluíram que o fator mais importante para a gestão de recursos hídricos é a negociação e a comunicação;

3. Uso da ferramenta: todos os jogadores afirmaram que negociaram de forma ampla, mas que a apresentação gráfica das mensagens deve ser revista;

4. Existência de jogadores virtuais: dois jogadores acharam que poderia haver algum jogador virtual para o papel de Proprietário Particular. Um dos jogadores no papel de Proprietário Particular elogiou as negociações que teve com o Representante dos SemTeto (jogador virtual), dizendo que o mesmo foi muito habilidoso durante a negociação.

\subsubsection{Variáveis Definidas para os Perfis Comportamentais}

A avaliação dos perfis comportamentais dos jogadores virtuais é realizada a partir das variáveis definidas para cada um dos perfis, apresentadas na seção 9.2. Aqui, são apresentadas algumas destas variáveis ${ }^{4}$, que apresentam resultados interessantes para análise.

Por exemplo, para o Prefeito C, que tinha um perfil comportamental com interesse econômico, os valores iniciais da porcentagem dos serviços urbanos (0,833333), na Tabela 38 e dos índices sociais de desenvolvimento (0,916670), na Tabela 39, não foram alterados, visto que não houve novas famílias instaladas no município e este jogador não realizou nenhuma ação que pudesse alterar estes dados, já que esta estratégia não faz parte de seus objetivos. Já o percentual de desemprego do município, mostrado na Tabela 40 foi reduzido da terceira para a

\footnotetext{
${ }^{4}$ Verificar no Anexo E todos os valores encontrados para as variáveis definidas para os perfis comportamentais, bem como a análise completa destes dados.
} 
quarta rodada (de 0,072222 para 0,0680556) pois um indústria foi instalada no município. Tal fato gerou um crescimento no índice de poluição global da terceira para a quarta rodada (de $6.539,70$ para $8.188,59$ ), conforme mostrado na Tabela 41. Este índice é superior aos índices apresentados nas rodadas anteriores.

\begin{tabular}{|l|rr|}
\hline \hline \multicolumn{3}{|c|}{ JM - Jogo-Teste 1 } \\
\hline Rodada & \% Serviços Urbanos - Município C \\
Rodada 1 & 0,833333 \\
\hline Rodada 2 & 0,833333 \\
\hline Rodada 3 & 0,833333 \\
\hline Rodada 4 & 0,833333 \\
\hline
\end{tabular}

Tabela 38: Percentual de Serviços Urbanos no Município C no Jogo-Teste 1 com JM.

\begin{tabular}{|l|r|}
\hline \hline \multicolumn{2}{|c|}{ JM - Jogo-Teste 1 } \\
\hline Rodada & \% Desenvolvimento Social - Município C \\
Rodada 1 & 0,916670 \\
\hline Rodada 2 & 0,916670 \\
\hline Rodada 3 & 0,916670 \\
\hline Rodada 4 & 0,916670 \\
\hline
\end{tabular}

Tabela 39: Percentual de Desenvolvimento Social no Município C no Jogo-Teste 1 com JM.

\begin{tabular}{|l|r|}
\hline \hline \multicolumn{2}{|c|}{ JM - Jogo-Teste 1 } \\
\hline Rodada & \% Desemprego - Município C \\
Rodada 1 & 0,000000 \\
\hline Rodada 2 & 0,072222 \\
\hline Rodada 3 & 0,072222 \\
\hline Rodada 4 & 0,0680556 \\
\hline
\end{tabular}

Tabela 40: Percentual de Desemprego para o Jogador Virtual Prefeito C no Jogo-Teste 1 com JM.

A partir dos resultados apresentados nas variáveis dos jogadores virtuais utilizados no primeiro jogo-teste misto, pode-se afirmar que os jogadores virtuais executaram os papéis definidos de acordo com perfis comportamentais definidos.

\subsubsection{Análise da Troca de Mensagens}

\section{a) Negociações Bilaterais}

A Tabela 42 apresenta as propostas de compra/aluguel de lotes entre os jogadores e a Tabela 43 apresenta as solicitações de infra-estrutura dos jogadores, para a rodada 1. 


\begin{tabular}{|l|r|}
\hline \hline \multicolumn{2}{|c|}{ JM - Jogo-Teste 1 } \\
\hline Rodada & Índice de Poluição do Reservatório \\
\hline \hline Inicial & $4.800,00$ \\
\hline Rodada 1 & $6.343,44$ \\
\hline Rodada 2 & $6.823,20$ \\
\hline Rodada 3 & $6.539,70$ \\
\hline Rodada 4 & $8.188,59$ \\
\hline \hline
\end{tabular}

Tabela 41: Poluição Global do Reservatório - Jogo-Teste 1 com JM.

\begin{tabular}{|l|c|c|c|c|c|}
\hline \hline \multicolumn{7}{|c|}{ JM - Jogo-Teste 1 - Rodada 1 } \\
\hline & Comprador & Vendedor & Tipo & Lote & Valor \\
\hline \hline 1 & SemTeto & Proprietário1 & propose & 3 & 2.000 \\
\hline 2 & SemTeto & AguaPura & propose & 4 & 2.000 \\
\hline 3 & SemTeto & Proprietário2 & propose & 5 & 2.000 \\
\hline 4 & AguaPura & Proprietário1 & propose & 3 & 2.000 \\
\hline 5 & AguaPura & Proprietário2 & propose & 4 & 2.000 \\
\hline 6 & AguaPura & Proprietário2 & propose & 6 & 2.000 \\
\hline 7 & AguaPura & Proprietário1 & propose & 11 & 2.000 \\
& AguaPura & Proprietário1 & request & 11 & 3.000 \\
\hline 8 & AguaPura & Proprietário2 & propose & 14 & 2.000 \\
\hline 9 & AguaPura & Proprietário1 & propose & 19 & 2.000 \\
\hline 10 & AguaPura & Proprietário1 & propose & 20 & 2.000 \\
\hline 11 & AguaPura & Proprietário2 & propose & 22 & 2.000 \\
\hline 12 & AguaPura & Proprietário9 & propose & 29 & 3.000 \\
\hline 13 & AguaPura & Proprietário9 & propose & 30 & 3.000 \\
\hline 14 & AguaPura & Proprietário1 & propose & 28 & 3.000 \\
& AguaPura & Proprietário1 & accept_proposal & 28 & 3.000 \\
\hline 15 & Proprietário8 & Proprietário3 & propose & 16 & 4.000 \\
& Proprietário8 & Proprietário3 & accept_proposal & 16 & 4.000 \\
\hline 16 & Proprietário9 & Proprietário3 & propose & 16 & 4.000 \\
\hline 17 & Proprietário9 & Proprietário3 & propose & 24 & 4.000 \\
& Proprietário9 & Proprietário3 & accept_proposal & 24 & 4.000 \\
\hline 18 & Proprietário8 & Proprietário3 & propose & 24 & 4.000 \\
\hline 19 & Proprietário7 & Proprietário3 & propose & 16 & 1.000 \\
\hline \hline
\end{tabular}

Tabela 42: Negociações Bilaterais de Compra/Aluguel no Jogo-Teste 1 com JM na Rodada 1.

\begin{tabular}{|c|c|c|c|c|}
\hline \hline \multicolumn{5}{|c|}{ JM - Jogo-Teste 1 - Rodada 1 } \\
\hline & Prefeito & Quem solicita & Tipo & Lote \\
\hline \hline 1 & PrefeitoA & Proprietário4 & need_water & 27 \\
\hline 2 & PrefeitoA & Proprietário4 & need_water & 35 \\
\hline 3 & PrefeitoA & Proprietário4 & need_water & 43 \\
\hline 4 & PrefeitoA & Proprietário4 & need_water & 44 \\
\hline \hline
\end{tabular}

Tabela 43: Negociações Bilaterais de Infra-estrutura no Jogo-Teste 1 com JM na Rodada 1. 
O jogo-teste 1 com JM teve um número de propostas de compra/aluguel bastante elevado. Comparativamente ao jogo-teste 1 com JH (mesmo grupo de jogadores), pode-se perceber que os jogadores reais tinham maior domínio das regras do jogo e que negociaram de forma ampla. Pelas propostas apresentadas na Tabela 42, verifica-se que os jogadores virtuais iniciaram a maioria das negociações de compra/aluguel de lotes e conseguiram concluir algumas negociações. Talvez esse seja um dos fatores do maior número de negociações, em comparação aos jogos-teste com JH.

Outro fator de relevância é que este grupo de jogadores reais era o mais inexperiente dos três grupos de teste em relação a jogos do tipo RPG e foi o que apresentou uma grande motivação para jogar, entender e aprender sobre o jogo e o domínio do problema, apresentando o melhor desempenho, em termos de quantidade de negociações realizadas nos três jogos-teste com JM.

\section{b) Negociações Coletivas}

A Tabela 44 apresenta as estratégias coletivas negociadas na rodada 1 do jogo-teste 2 com JM.

\begin{tabular}{|l|c|c|c|c|}
\hline \hline \multicolumn{5}{|c|}{ JM - Jogo-Teste 1 - Rodada 1 } \\
\hline Estratégia & Propor & Aceitar & Rejeitar & C-Proposta \\
\hline \hline 1 - Ampliar rede de água & $1,4,5,6,7,8,9$ & $2,7, \mathrm{AP}$ & $\mathrm{C}$ & \\
\hline 2 - Ampliar rede de esgoto & $1,4,8,9$ & $1, \mathrm{AP}$ & $\mathrm{C}$ & \\
\hline $\begin{array}{l}\text { 3 - Delimitar a área urbana de } \\
\text { meu município: Lotes 27 }\end{array}$ & 4 & & & 2 (Lote 23) \\
\hline $\begin{array}{l}\text { 3 - Delimitar a área urbana de } \\
\text { meu município: Lotes 23,24,39 }\end{array}$ & $\mathrm{B}$ & & & \multirow{2}{*}{ (Lote 23) } \\
\hline $\begin{array}{l}\text { 5 - Delimitar a área rural de } \\
\text { meu município: } \\
\text { Lotes 5,6,22,30,37,38 }\end{array}$ & & & & \\
\hline $\begin{array}{l}\text { 5 - Delimitar a área rural de } \\
\text { meu município: Lotes 63,64 }\end{array}$ & 7 & & & \\
\hline $\begin{array}{l}\text { 6 - Ações que incentivam o uso } \\
\text { da área rural de meu município }\end{array}$ & 5 & 8,9 & $2,3, \mathrm{ST}$ & \\
\hline 8 - Prefeitos auxiliam os SemTeto & $2, \mathrm{ST}$ & & $\mathrm{C}$ & \\
\hline $\begin{array}{l}\text { 10 - Limitar áreas residenciais } \\
\text { para Sem Teto }\end{array}$ & $\mathrm{A}$ & $\mathrm{A}, \mathrm{ST}$ & 2 & \\
\hline \hline
\end{tabular}

Tabela 44: Negociações Coletivas no Jogo-Teste 1 com JM na Rodada 1.

A Tabela 44 mostra que as estratégias coletivas mais negociadas foram as solicitações de infra-estrutura, onde os jogadores negociaram mais fortemente sobre as estratégias 1 (Ampliar rede de água) e 2 (Ampliar rede de esgoto). 


\begin{tabular}{|l|c|c|}
\hline \hline \multicolumn{2}{|c|}{ JM - Jogo-Teste 1 - Rodada 1 } \\
\hline Estratégia & Jogador Aceitou & Ações Executadas Posterior. \\
\hline \hline 1 - Ampliar rede de água & AP & Água em lote 28 \\
\hline 2 - Ampliar rede de esgoto & AP & Esgoto em lote 25 \\
\hline \hline
\end{tabular}

Tabela 45: Estratégias Coletivas Aceitas na Rodada 1 e Ações Executadas em Rodadas Posteriores no Jogo-Teste 1 com JM.

\begin{tabular}{|l|c|c|}
\hline \hline \multicolumn{2}{|c|}{ JM - Jogo-Teste 1 - Rodada 2 } \\
\hline Estratégia & Jogador Aceitou & Ações Executadas Posterior. \\
\hline \hline 1 - Ampliar rede de água & AP & Água em lote 11 \\
\hline 2 - Ampliar rede de esgoto & AP & - \\
\hline \hline
\end{tabular}

Tabela 46: Estratégias Coletivas Aceitas na Rodada 2 e Ações Executadas em Rodadas Posteriores no Jogo-Teste 1 com JM.

Em relação às estratégias aceitas pelos jogadores que podem alterar o coletivo e cumpridas em rodadas posteriores, as Tabelas 45, 46 e 47 apresentam as ações executadas com este intuito. O único jogador que aceitou estratégias coletivas e tinha poder de alterar o coletivo foi o jogador no papel de Administrador da AguaPura, que era um jogador virtual. Este jogador agiu de acordo com as regras definidas para o seu perfil comportamental. Contudo, percebe-se que na rodada 1 coletiva, este jogador aceitou ampliar a rede de esgoto (Tabela 44), mas na rodada posterior, não executou nenhuma ação neste sentido (Tabela 46). Como nenhuma das regras definidas no perfil comportamental deste jogador foi atendida, o jogador virtual não pode cumprir com o que foi negociado na fase 2 (coletiva). Este fato mostra que a definição do perfil comportamental com interesse protetor-ambientalista para o papel de Administrador da AguaPura está incompleto. Um dos objetivos deste papel é a ampliação da rede de esgoto e na fase 2 este papel interage corretamente e aceita efetivar esta ação, mas não há em sua base de conhecimento uma regra que atenda este objetivo em todas as possíveis situações do jogo, para posterior efetivação.

A atuação de todos os jogadores virtuais nas negociações bilaterais e coletivas ocorreu de forma eficiente perante os jogadores reais.

\begin{tabular}{|l|c|c|}
\hline \hline \multicolumn{2}{|c|}{ JM - Jogo-Teste 1 - Rodada 3 } \\
\hline Estratégia & Jogador Aceitou & Ações Executadas Posterior. \\
\hline \hline 1 - Ampliar rede de água & AP & Água em lote 22 \\
\hline 2 - Ampliar rede de esgoto & AP & Esgoto em lote 22 \\
\hline \hline
\end{tabular}

Tabela 47: Estratégias Coletivas Aceitas na Rodada 3 e Ações Executadas em Rodadas Posteriores no Jogo-Teste 1 com JM. 


\subsubsection{Jogo-Teste 2 com JM}

A composição utilizada para os jogadores virtuais encontra-se na Tabela 48.

\begin{tabular}{|l|c|r|r|}
\hline \hline \multicolumn{4}{|c|}{ JM - Jogo-Teste 2 } \\
\hline Papel & Perfil Comp. & Identif.Jogadores & Tipo Jogador \\
\hline \hline Proprietário Particular & Econômico & Proprietários 2 e 3 & Virtual \\
\hline Proprietário Particular & Ambientalista & Proprietários 8 e 9 & Virtual \\
\hline Proprietário Particular & - & Proprietários 1,4,5,6 e 7 & Real \\
\hline Prefeito & Social & Prefeito C & Virtual \\
\hline Prefeito & - & Prefeitos A e B & Real \\
\hline Administrador AguaPura & Racional & AguaPura & Virtual \\
\hline Representante SemTeto & Social & SemTeto & Virtual \\
\hline \hline
\end{tabular}

Tabela 48: Composição Papéis e Perfis Comportamentais no Jogo-Teste 2 com JM.

\subsubsection{Análise das Respostas Fornecidas pelos Jogadores nos Ques- tionários Pós-Jogo}

Das respostas dos jogadores nos questionários pós-jogo foram analisados quatro aspectos:

1. Avaliação do jogo: os jogadores ficaram satisfeitos com suas atuação no jogo e disseram que o mesmo atendeu suas expectativas. Sugeriram mais rodadas, para um melhor entendimento da evolução de todo sistema e também que a fase 2 (coletiva) fosse mais curta;

2. Análise do jogo: os jogadores acharam que durante o jogo houve uma relação de competição entre os jogadores, diferentemente do jogo-teste $2 \mathrm{com} \mathrm{JH}$, onde este grupo de jogadores apontou uma relação de cooperação entre os jogadores. Também concluíram que em relação à gestão de recursos hídricos os recursos são compartilhados e limitados, e que a comunicação é decisiva para a negociação;

3. Uso da ferramenta: os jogadores afirmaram que um chat fechado é muito utilizando em comércio via Internet e que atende às necessidades do jogo, diferentemente do que foi dito no jogo-teste $2 \mathrm{com} J H$, onde sugeriram um chat com mensagens abertas. Sugeriam que para cada jogador fosse definida uma cor para as mensagens, de forma a facilitar a comunicação;

4. Existência de jogadores virtuais: um jogador achou que o Prefeito C era um jogador virtual pois emitia muitas mensagens durante o jogo e que o Representante dos SemTeto também era virtual pois era muito experiente. 


\subsubsection{Variáveis Definidas para os Perfis Comportamentais}

Novamente, apenas algumas variáves dos perfis comportamentais são analisadas nesta seção ${ }^{5}$. No caso do Prefeito C com perfil comportamental com interesse social obteve um percentual de servicos urbanos superior a $100 \%(1,11111)^{6}$, conforme mostra a Tabela 49, e um bom percentual índice de desenvolvimento social $(0,888889)$, conforme indica a Tabela 50. O índice de desenvolvimento social decresceu pois o percentual de desemprego aumentou muito, terminando a rodada 4 em mais de $30 \%$, conforme Tabela 51 .

O Administrador da AguaPura tinha preocupação com a poluição do reservatório e segundo os dados da Tabela 52 conseguiu controlar os índices até a rodada 3. Como houve uma exploção de famílias morando em favelas, conforme indica a Tabela 53, tanto o percentual de desemprego quanto a poluição aumentaram muito na rodada 4.

\begin{tabular}{|l|r|}
\hline \hline \multicolumn{3}{|c|}{ JM - Jogo-Teste 2 } \\
\hline Rodada & \%Percentual Serviços Urbanos \\
\hline \hline Rodada 1 & 0,83333 \\
\hline Rodada 2 & 1,25000 \\
\hline Rodada 3 & 1,07143 \\
\hline Rodada 4 & 1,11111 \\
\hline \hline
\end{tabular}

Tabela 49: Percentual de Serviços Urbanos no Município C no Jogo-Teste 2 com JM.

\begin{tabular}{|l|r|}
\hline \hline \multicolumn{2}{|c|}{ JM - Jogo-Teste 2 } \\
\hline Rodada & \%Desenvolvimento Social \\
\hline \hline Rodada 1 & 0,916670 \\
\hline Rodada 2 & 0,958333 \\
\hline Rodada 3 & 0,907143 \\
\hline Rodada 4 & 0,888889 \\
\hline \hline
\end{tabular}

Tabela 50: Percentual de Serviços Urbanos no Município C no Jogo-Teste 2 com JM.

Pode-se afirmar que os jogadores virtuais utilizados no jogo-teste 2 com JM executaram, para os papéis escolhidos, corretamente os perfis comportamentais definidos.

\footnotetext{
${ }^{5}$ Verificar no Anexo E todos os valores encontrados para as variáveis definidas para os perfis comportamentais, bem como a análise completa destes dados.

${ }^{6} \mathrm{O}$ Prefeito $\mathrm{C}$ instalou infra-estruturas em número superior ao necessário, proporcionalmente ao número de famílias morando em seu município. O cálculo de todas as variáveis é apresentado na seção 5.2.3.
} 


\begin{tabular}{|l|r|}
\hline \hline \multicolumn{2}{|c|}{ JM - Jogo-Teste 2 } \\
\hline Rodada & \%Desemprego \\
\hline \hline Rodada 1 & 0,069444 \\
\hline Rodada 2 & 0,009722 \\
\hline Rodada 3 & 0,147619 \\
\hline Rodada 4 & 0,310185 \\
\hline \hline
\end{tabular}

Tabela 51: Percentual de Desemprego no Município C no Jogo-Teste 2 com JM.

\begin{tabular}{|l|r|}
\hline \hline \multicolumn{2}{|c|}{ JM - Jogo-Teste 2 } \\
\hline Rodada & Índice de Poluição do Reservatório \\
\hline \hline Inicial & $4.800,00$ \\
\hline Rodada 1 & $6.343,44$ \\
\hline Rodada 2 & $6.602,89$ \\
\hline Rodada 3 & $7.216,36$ \\
\hline Rodada 4 & $9.475,80$ \\
\hline \hline
\end{tabular}

Tabela 52: Poluição Global do Reservatório no Jogo-Teste 2 com JM.

\begin{tabular}{|l|r|}
\hline \hline \multicolumn{2}{|c|}{ JM - Jogo-Teste 2 } \\
\hline Rodada & \% Moradores em Favelas \\
\hline \hline Inicial & 0,0 \\
\hline Rodada 1 & 0,0 \\
\hline Rodada 2 & 0,0 \\
\hline Rodada 3 & 0,060423 \\
\hline Rodada 4 & 0,110803 \\
\hline
\end{tabular}

Tabela 53: Percentual de Famílias Morando em Favelas - Jogo-Teste 2 com JM. 


\subsubsection{Análise da Troca de Mensagens}

\section{a) Negociações Bilaterais}

A Tabela 54 apresenta as propostas de compra/aluguel de lotes entre os jogadores e a Tabela 55 apresenta as solicitações de infra-estrutura dos jogadores para a rodada 1 do jogo-teste 2 com JM.

\begin{tabular}{|c|c|c|c|c|c|}
\hline \multicolumn{6}{|c|}{ JM - Jogo-Teste 2 - Rodada 1} \\
\hline & Comprador & Vendedor & Tipo & Lote & Valor \\
\hline \multicolumn{6}{|l|}{ Rodada 1} \\
\hline \multirow[t]{8}{*}{1} & PrefeitoB & Proprietário9 & propose & 39 & 1.300 \\
\hline & PrefeitoB & Proprietário9 & request & 39 & 1.300 \\
\hline & PrefeitoB & Proprietário9 & propose & 39 & 1.700 \\
\hline & PrefeitoB & Proprietário9 & request & 39 & 1.700 \\
\hline & PrefeitoB & Proprietário9 & propose & 39 & 1.900 \\
\hline & PrefeitoB & Proprietário9 & request & 39 & 1.900 \\
\hline & PrefeitoB & Proprietário9 & request & 39 & 2.000 \\
\hline & PrefeitoB & Proprietário9 & accept_proposal & 39 & 2.000 \\
\hline \multirow[t]{4}{*}{2} & PrefeitoB & Proprietário2 & propose & 5 & 1.300 \\
\hline & PrefeitoB & Proprietário2 & request & 5 & 1.300 \\
\hline & PrefeitoB & Proprietário2 & propose & 5 & 2.000 \\
\hline & PrefeitoB & Proprietário2 & accept_proposal & 5 & 2.000 \\
\hline \multirow[t]{3}{*}{3} & PrefeitoB & Proprietário3 & propose & 24 & 1.700 \\
\hline & PrefeitoB & Proprietário3 & request & 24 & 1.700 \\
\hline & PrefeitoB & Proprietário3 & propose & 24 & 1.900 \\
\hline \multirow[t]{2}{*}{4} & Proprietário8 & Proprietário3 & propose & 16 & 4.000 \\
\hline & Proprietário8 & Proprietário3 & accept_proposal & 16 & 4.000 \\
\hline 5 & Proprietário9 & Proprietário3 & propose & 16 & 4.000 \\
\hline \multirow[t]{2}{*}{6} & Proprietário8 & Proprietário2 & propose & 22 & 4.000 \\
\hline & Proprietário8 & Proprietário2 & accept_proposal & 22 & 4.000 \\
\hline 7 & Proprietário9 & Proprietário2 & propose & 22 & 4.000 \\
\hline \multirow[t]{2}{*}{8} & Proprietário9 & Proprietário2 & propose & 23 & 4.000 \\
\hline & Proprietário9 & Proprietário2 & accept_proposal & 23 & 4.000 \\
\hline 9 & Proprietário8 & Proprietário2 & propose & 23 & 4.000 \\
\hline \multirow[t]{2}{*}{10} & Proprietário8 & Proprietário3 & propose & 24 & 4.000 \\
\hline & Proprietário8 & Proprietário3 & accept_proposal & 24 & 4.000 \\
\hline
\end{tabular}

Tabela 54: Negociações Bilaterais de Compra/Aluguel no Jogo-Teste 2 com JM na Rodada 1.

Pela Tabela 54, verifica-se a maioria das propostas de compra/aluguel foram realizadas por jogadores reais interagindo com jogadores virtuais. Relacionado às solicitações de infra-estrutura, novamente houve apenas solicitações de infraestrutura de água e de esgoto, sendo a maioria destas solicitadas por jogadores virtuais (Proprietários Particulares 8 e 9).

\section{b) Negociações Coletivas}




\begin{tabular}{|l|l|l|l|c|}
\hline \hline \multicolumn{5}{|c|}{ JM - Jogo-Teste 2 - Rodada 1 } \\
\hline & Prefeito & Quem solicita & Tipo & Lote \\
\hline \hline Rodada 1 & & & & \\
\hline 1 & PrefeitoB & Proprietário8 & need_sanitation & 60 \\
\hline 2 & PrefeitoB & Proprietário8 & need_sanitation & 61 \\
\hline 3 & PrefeitoB & Proprietário9 & need_sanitation & 60 \\
\hline 4 & PrefeitoB & Proprietário9 & need_sanitation & 61 \\
\hline \hline
\end{tabular}

Tabela 55: Negociações Bilaterais de Infra-estrutura no Jogo-Teste 2 com JM na Rodada 1.

A tabela 56 apresenta as estratégias coletivas negociadas na rodada 1 do jogo-teste 2 com JM.

\begin{tabular}{|l|c|c|c|c|}
\hline \hline \multicolumn{5}{|c|}{ JM - Jogo-Teste 2 - Rodada 1 } \\
\hline Estratégia & Propor & Aceitar & Rejeitar & C-Proposta \\
\hline \hline 1 - Ampliar rede de água & $8,9,4, \mathrm{C}, \mathrm{AP}$ & $\mathrm{B}$ & & \\
\hline $\begin{array}{l}\text { 4 - Ações que incentivam o uso da } \\
\text { área urbana de meu município }\end{array}$ & $\mathrm{B}$ & 2,3 & $8,9, \mathrm{AP}$ & \\
\hline $\begin{array}{l}\text { 6 - Ações que incentivam o uso } \\
\text { da área rural de meu município }\end{array}$ & 4 & 8,9 & 2,3 & \\
\hline $\begin{array}{l}\text { 9 - Incentivo a construção de } \\
\text { novas indústrias na região urbana } \\
\text { para geração de empregos }\end{array}$ & $\mathrm{A}$ & $\mathrm{AP}$ & & \\
\hline $\begin{array}{l}\text { 10 - Limitar áreas residenciais } \\
\text { para SemTeto }\end{array}$ & $\mathrm{ST}$ & $\mathrm{A}, \mathrm{C}$ & 2 & \\
\hline \hline
\end{tabular}

Tabela 56: Negociações Coletivas no Jogo-Teste 2 com JM Rodada 1.

A Tabela 56 apresenta, novamente, que as estratégias 1 (Ampliar rede de água) e 2 (Ampliar rede de esgoto) foram as mais negociadas entre os jogadores na primeira rodada. Os dados completos mostram também houve uma redução de ações negociadas no decorrer das rodadas (ver no Anexo E). O jogador virtual no papel de Prefeito C, que tinha um perfil comportamental com interesse social, teve grande preocupação em alocar as famílias de SemTeto da melhor forma possível, como pode ser verificado pelas estratégias coletivas que aceitou executar em rodadas posteriores: 8 - Prefeitos auxiliam os SemTeto e 10 - Limiar áreas residenciais aos SemTeto.

Em relação às estratégias aceitas pelos jogadores que podem alterar o coletivo e cumpridas em rodadas posteriores, as Tabelas 57, 58 e 59 apresentam as ações executadas com este intuito. Todos os jogadores que tinham poder de alterar o coletivo as aceitaram estratégias coletivas: Prefeitos A, B e C e Administrador da AguaPura. Dois destes jogadores eram virtuais: Prefeito C e Administrador da AguaPura. Destes jogadores, o Administrador da AguaPura tem definido 


\begin{tabular}{|l|c|c|}
\hline \hline \multicolumn{2}{|c|}{ JM - Jogo-Teste 2 - Rodada 1 } \\
\hline Estratégia & Jogador Aceitou & Ações Executadas Posterior. \\
\hline \hline 1 - Ampliar rede de água & B & \\
\hline $\begin{array}{l}\text { 9 - Incentivo a construção de } \\
\text { novas indústrias na região } \\
\text { urbana para geração de } \\
\text { empregos }\end{array}$ & & \\
\hline $\begin{array}{l}\text { 10 - Limitar áreas residenciais } \\
\text { para Sem Teto }\end{array}$ & AP & A: - C: Escola em lotes 60 e 61 \\
\hline
\end{tabular}

Tabela 57: Estratégias Coletivas Aceitas na Rodada 1 e Ações Executadas em Rodadas Posteriores no Jogo-Teste 2 com JM.

\begin{tabular}{|l|c|c|}
\hline \hline \multicolumn{2}{|c|}{ JM - Jogo-Teste 2 - Rodada 2 } \\
\hline Estratégia & Jogador Aceitou & Ações Executadas Posterior. \\
\hline \hline 2 - Ampliar rede de esgoto & AP & Esgoto em lote 26 \\
\hline $\begin{array}{l}\text { 8 - Prefeitos auxiliam os } \\
\text { SemTeto }\end{array}$ & C & Água em lote 52 (invadido) \\
\hline $\begin{array}{l}\text { 10 - Limitar áreas residenciais } \\
\text { para Sem Teto }\end{array}$ & $\mathrm{C}$ & \\
\hline
\end{tabular}

Tabela 58: Estratégias Coletivas Aceitas na Rodada 2 e Ações Executadas em Rodadas Posteriores no Jogo-Teste 2 com JM.

\begin{tabular}{|l|c|c|}
\hline \hline \multicolumn{2}{|c|}{ JM - Jogo-Teste 2 - Rodada 3 } \\
\hline Estratégia & Jogador Aceitou & Ações Executadas Posterior. \\
\hline \hline Rodada 3 & & \\
\hline 1 - Ampliar rede de água & AP & Água em lote 15 \\
\hline 2 - Ampliar rede de esgoto & AP & Esgoto em lote 15 \\
\hline $\begin{array}{l}\text { 8 - Prefeitos auxiliam os } \\
\text { SemTeto }\end{array}$ & C & Esgoto em lote 52 (invadido) \\
\hline
\end{tabular}

Tabela 59: Estratégias Coletivas Aceitas na Rodada 3 e Ações Executadas em Rodadas Posteriores no Jogo-Teste 2 com JM. 
como objetivo de seu perfil comportamental aceitar a estratégia coletiva número 9 - Incentivo a construção de novas indústrias na região urbana para geração de empregos, mas não tem ações para cumprir este compromisso em sua base de conhecimento. Neste jogo-teste, esta foi a única estratégia coletiva aceita pelos jogadores virtuais não cumprida em rodadas seguintes. No jogo-teste $1 \mathrm{com}$ JM foi verificado que outra estratégia coletiva (2 - Ampliar rede de esgoto) foi aceita, mas não foi cumprida por um jogador virtual (administrador da AguaPura com o perfil comportamental com interesse protetor-ambientalista). Neste jogoteste, novamente o papel de Administrador da AguaPura possui uma base de conhecimento incompleta, mas agora para o perfil comportamental com interesse racional. Já os jogadores reais que executaram os papéis de Prefeito A e Prefeito $\mathrm{B}$ aceitaram estratégias coletivas, mas não executaram as ações relacionadas nas rodadas seguintes.

O levantamento dos dados das negociações bilaterais e coletivas contradiz o que os jogadores reais responderam na questão 4 do questionário pós-jogo ${ }^{7}$, onde desejariam um número maior de rodadas de jogo para colocar todas as suas ações em prática. Pelos dados analisados, verifica-se uma redução do número de negociações durante as rodadas, podendo-se imaginar que os jogadores estivessem desmotivados ou sem opções de jogo. Talvez uma possível resposta é que os jogadores reais afirmaram que ainda tinham dificultades em entender as regras do jogo no questionário pós-jogo (questão 10), o que influenciou na menor interação entre os jogadores.

Novamente, os jogadores virtuais participaram das negociações de forma eficiente, interagindo entre si e com os jogadores reais, tanto na fase 1 quanto na fase 2 (coletiva).

\subsubsection{Jogo-Teste 3 com JM}

A composição utilizada para os jogadores virtuais é indicada na Tabela 60.

No jogo-teste 3 com JM, diferentemente dos outros dois apresentados anteriormente, foram utilizados somente 6 jogadores virtuais, visto que um dos jogadores reais solicitou para jogar novamente, resultando então em 8 jogadores humanos. Como os testes dos perfis comportamentais não seriam prejudicados, visto que todos os perfis definidos seriam testados, foi realizada esta mudança de configuração na quantidade de jogadores reais/virtuais neste jogo-teste misto. Este aspecto também pode ser importante para verificar a influência do número

\footnotetext{
${ }^{7}$ Ver as principais respostas dos jogadores no Anexo E.
} 


\begin{tabular}{|l|c|c|c|}
\hline \hline \multicolumn{5}{|c|}{ JM - Jogo-Teste 3 } \\
\hline Papel & Perfil Comp. & Identif.Jogadores & Tipo Jogador \\
\hline \hline Proprietário Particular & Econômico & Proprietários 2,4 e 8 & Virtual \\
\hline Proprietário Particular & Ambientalista & Proprietários 1 e 9 & Virtual \\
\hline Proprietário Particular & - & Proprietários 3,5,6 e 7 & Real \\
\hline Prefeito & Ambientalista & Prefeito C & Virtual \\
\hline Prefeito & - & Prefeitos A e B & Real \\
\hline Administrador AguaPura & - & AguaPura & Real \\
\hline Representante SemTeto & - & SemTeto & Real \\
\hline \hline
\end{tabular}

Tabela 60: Composição Papéis e Perfis Comportamentais no Jogo-Teste 3 com JM.

de jogadores virtuais no jogo, visto que neste jogo-teste a maioria dos papéis ditos "importantes" no jogo (Prefeitos, Administrador da AguaPura e Representante dos SemTeto) foi executado por jogadores reais.

\subsubsection{Análise das Respostas Fornecidas pelos Jogadores nos Ques- tionários Pós-Jogo}

Quatro aspectos foram analisados a partir das respostas dos jogadores nos questionários pós-jogo:

1. Avaliação do jogo: os jogadores ficaram satisfeitos com o jogo, mas não com suas atuações. Sugeriram um aumento no tempo de negociação da Fase 1;

2. Análise do jogo: segundo os jogadores, os Proprietários Particulares tinham uma relação de competição com os outros jogadores e os Prefeitos e o administrador da AguaPura uma relação de cooperação com os outros jogadores. Os jogadores concluíram que ações individuais não ajudam na preservação ambiental;

3. Uso da ferramenta: os jogadores acharam que a interface não era intuitiva (tipos de mensagens, justificativas, etc.) e que o sistema de chat aberto seria melhor para as negociações;

4. Existência de jogadores virtuais: dois jogadores acharam que os Proprietários Particulares 2 e 8 eram virtuais, pois respondiam muito rápido as mensagens enviadas durante as negociações. Outro jogador achou que o Prefeito A fosse virtual pois tinha um comportamento muito correto durante o jogo. 


\subsubsection{Variáveis Definidas para os Perfis Comportamentais}

Apenas algumas variáves dos perfis comportamentais são analisadas nesta seção ${ }^{8}$. O Prefeito C, que tinha um perfil comportamental com interesse ambientalista realizou diversos investimentos em infra-estrutura, o que pode ser comparado pelo percentual de famílias conectadas a rede de esgoto, conforme mostrado na Tabela 62, que ao final da rodada 4 foi de mais de $63 \%$. Contudo, os percentuais para o índice de desenvolvimento social, indicado na Tabela 63, diminuiram progressivamente, visto que o percentual de famílias morando em favelas aumentou rapidamente, conforme mostra a Tabela 64, gerando uma taxa de desemprego elevada, superior a $22 \%$, conforme mostra a Tabela 65. Com estes dados, pode-se verificar também que a poluição do reservatório, indicada na Tabela 66, foi elevada. Aliás, este foi o maior índice de poluição obtido em todos os jogos-teste com JM. O jogador real que executou o papel de Representante dos SemTeto não teve preocupação social e alocou as famílias em quaisquer condições. Isso se confirma pela resposta para a questão 1 do questionário pós-jogo dada pelo jogador real que executou o Representante dos SemTeto sobre seus objetivos no jogo, onde este declarou que "queria testar as diferentes possibilidades do seu papel, como invasão, alocação, pressionar os Prefeitos". Assim, o Prefeito C, que tinha um perfil comportamental com interesse ambientalista, tentou exercer seu papel de forma a melhorar a qualidade ambiental de seu município e da região, que são os objetivos deste perfil, mas foi "anulado" pela massiva quantidade de ações negativas realizadas pelo Representante dos SemTeto.

\begin{tabular}{|l|r|}
\hline \hline \multicolumn{2}{|c|}{ JM - Jogo-Teste 3 } \\
\hline Rodada & \%Serviços Urbanos \\
\hline \hline Rodada 1 & 0,833333 \\
\hline Rodada 2 & 0,833333 \\
\hline Rodada 3 & 0,833333 \\
\hline Rodada 4 & 0,714286 \\
\hline \hline
\end{tabular}

Tabela 61: Percentual de Serviços Urbanos no Jogo-Teste 3 com JM.

Verifica-se que os jogadores virtuais utilizados no jogo-teste 3 com JM executaram suas ações de forma correta, a partir os objetivos pré-definidos para cada um dos tipos de perfil comportamental utilizados, o que não necessariamente gerou um resultado final similar ao que os objetivos definidos nos perfis se propunham a fazer. Por exemplo, o Prefeito $\mathrm{C}$ teve por objetivo melhorar a qualidade ambiental da região, mas não teve os resultados finais esperados, devido às ações

\footnotetext{
${ }^{8}$ Verificar no Anexo E todos os valores encontrados para as variáveis definidas para os perfis comportamentais, bem como a análise completa destes dados.
} 


\begin{tabular}{|l|r|r|}
\hline \hline \multicolumn{3}{|c|}{ JM - Jogo-Teste 3 } \\
\hline Rodada & \% Rede Esgoto & \% Rede Água \\
\hline \hline Inicial & 0,398671 & 0,996678 \\
\hline Rodada 1 & 0,385852 & 0,96463 \\
\hline Rodada 2 & 0,404984 & 0,965732 \\
\hline Rodada 3 & 0,626781 & 0,883191 \\
\hline Rodada 4 & 0,639386 & 0,895141 \\
\hline \hline
\end{tabular}

Tabela 62: Percentuais de Famílias Conectadas a Rede de Esgoto e a Rede de Água no Jogo-Teste 3 com JM.

\begin{tabular}{|l|r|}
\hline \hline \multicolumn{2}{|c|}{ JM - Jogo-Teste 3 } \\
\hline Rodada & \%Desenvolvimento Social \\
\hline \hline Rodada 1 & 0,916670 \\
\hline Rodada 2 & 0,916670 \\
\hline Rodada 3 & 0,950000 \\
\hline Rodada 4 & 0,900000 \\
\hline \hline
\end{tabular}

Tabela 63: Percentual de Desenvolvimento Social no Jogo-Teste 3 com JM.

\begin{tabular}{|l|r|}
\hline \hline \multicolumn{2}{|c|}{ JM - Jogo-Teste 3 } \\
\hline Rodada & \% Moradores em Favelas \\
\hline \hline Inicial & 0,0 \\
\hline Rodada 1 & 0,0321543 \\
\hline Rodada 2 & 0,0623053 \\
\hline Rodada 3 & 0,0854701 \\
\hline Rodada 4 & 0,1534530 \\
\hline \hline
\end{tabular}

Tabela 64: Percentual de Famílias Morando em Favelas no Jogo-Teste 3 com JM.

\begin{tabular}{|l|r|}
\hline \hline \multicolumn{2}{|c|}{ JM - Jogo-Teste 3 } \\
\hline Rodada & \%Desenvolvimento Social \\
\hline \hline Rodada 1 & 0,0958333 \\
\hline Rodada 2 & 0,0916667 \\
\hline Rodada 3 & 0,0916667 \\
\hline Rodada 4 & 0,221429 \\
\hline \hline
\end{tabular}

Tabela 65: Percentual de Desemprego no Jogo-Teste 3 com JM.

\begin{tabular}{|l|r|}
\hline \hline \multicolumn{2}{|c|}{ JM - Jogo-Teste 3 } \\
\hline Rodada & Índice de Poluição do Reservatório \\
\hline \hline Inicial & $4.800,00$ \\
\hline Rodada 1 & $6.343,44$ \\
\hline Rodada 2 & $8.075,12$ \\
\hline Rodada 3 & $9.589,71$ \\
\hline Rodada 4 & $10.242,20$ \\
\hline \hline
\end{tabular}

Tabela 66: Poluição Global do Reservatório no Jogo-Teste 3 com JM. 
dos outros jogadores.

\subsubsection{Análise da Troca de Mensagens}

\section{a) Negociações Bilaterais}

A Tabela 67 apresenta as propostas de compra/aluguel de lotes entre os jogadores para a rodada 1 do jogo-teste 3. As Tabelas 68, 69 e 70 apresentam as solicitações de infra-estrutura dos jogadores para as rodadas 2, 3 e 4, pois os jogadores não fizeram solicitações deste tipo na rodada 1. Já as Tabelas 71,72 e 73 apresentam as ações específicas realizadas pelo Representante dos SemTeto relacionadas com os outros jogadores.

Na primeira rodada, os jogadores realizaram muitas propostas de compra/aluguel de lotes por parte dos jogadores, conforme Tabela 67. No decorrer das rodadas, este número foi sendo reduzido ${ }^{9}$. Contudo, este tipo de atitude é normal por parte dos jogadores, visto que estes iniciam o jogo com metas pré-definidas e tentam executá-las já no início do jogo. No que se refere às solicitações de infra-estrutura, pode-se verificar que existiram tentativas de negociação entre o Administrador da AguaPura e o Prefeito B sobre a colocação de esgoto no lote 39, o que anteriormente não havia sido negociado pelos jogadores desta forma, conforme a Tabela 70. O Representante dos SemTeto tentou buscar lotes para alocar novas famílias junto a diversos jogadores, sem retorno a estas solicitações, como mostram as Tabelas 71, 72 e 73.

\section{b) Negociações Coletivas}

A tabela 74 apresenta as estratégias coletivas negociadas na rodada 1 do jogo-teste 3 com JM.

Pela Tabela 74, o maior número de negociações esteve relacionado as estratégias 1 (Ampliar rede de água) e 2 (Ampliar rede de esgoto). O jogador real no papel de Administrador da AguaPura negociou muito, mas não cumpriu os acordos feitos na fase 2 (coletiva), como pode ser visto pelas Tabelas 75, 76 e 77, apresentadas a seguir.

Em relação às estratégias aceitas pelos jogadores que podem alterar o coletivo e cumpridas em rodadas posteriores, as Tabelas 75, 76 e 77 apresentam as ações executadas com este intuito. Novamente, todos os jogadores que tinham

\footnotetext{
${ }^{9}$ Ver todos os dados no Anexo E.
} 


\begin{tabular}{|c|c|c|c|c|c|}
\hline \multicolumn{6}{|c|}{ "JM - Jogo-Teste 3 - Rodada 1} \\
\hline & Comprador & Vendedor & Tipo & Lote & Valor \\
\hline \multirow[t]{2}{*}{1} & AguaPura & Proprietário2 & propose & 22 & 1.500 \\
\hline & AguaPura & Proprietário2 & request & 22 & 1.500 \\
\hline \multirow[t]{2}{*}{2} & AguaPura & Proprietário5 & propose & 34 & 1.500 \\
\hline & AguaPura & Proprietário5 & accept_proposal & 34 & 1.500 \\
\hline \multirow[t]{2}{*}{3} & AguaPura & Proprietário8 & propose & 47 & 2.500 \\
\hline & AguaPura & Proprietário8 & accept_proposal & 47 & 2.500 \\
\hline \multirow[t]{2}{*}{4} & PrefeitoA & Proprietário8 & propose & 47 & 1.350 \\
\hline & PrefeitoA & Proprietário8 & request & 47 & 1.350 \\
\hline \multirow[t]{2}{*}{5} & Proprietário9 & Proprietário2 & propose & 22 & 4.000 \\
\hline & Proprietário9 & Proprietário2 & accept_proposal & 22 & 4.000 \\
\hline 6 & Proprietário1 & Proprietário2 & propose & 22 & 4.000 \\
\hline 7 & Proprietário9 & Proprietário2 & propose & 23 & 4.000 \\
\hline \multirow[t]{4}{*}{8} & Proprietário6 & Proprietário2 & propose & 22 & 1.000 \\
\hline & Proprietário6 & Proprietário2 & request & 22 & 1.000 \\
\hline & Proprietário6 & Proprietário2 & propose & 22 & 1.500 \\
\hline & Proprietário6 & Proprietário2 & reject_proposal & 22 & 1.500 \\
\hline \multirow[t]{2}{*}{9} & Proprietário5 & Proprietário7 & propose & 57 & 1.500 \\
\hline & Proprietário5 & Proprietário7 & request & 57 & 1.500 \\
\hline \multirow[t]{2}{*}{10} & Proprietário5 & Proprietário2 & propose & 22 & 1.500 \\
\hline & Proprietário5 & Proprietário2 & request & 22 & 1.500 \\
\hline \multirow[t]{4}{*}{11} & Proprietário5 & Proprietário8 & propose & 46 & 1.500 \\
\hline & Proprietário5 & Proprietário8 & request & 46 & 1.500 \\
\hline & Proprietário5 & Proprietário8 & propose & 46 & 2.000 \\
\hline & Proprietário5 & Proprietário8 & accept_proposal & 46 & 2.000 \\
\hline \multirow[t]{2}{*}{12} & Proprietário5 & Proprietário8 & propose & 47 & 1.500 \\
\hline & Proprietário5 & Proprietário8 & request & 47 & 1.500 \\
\hline \multirow[t]{2}{*}{13} & Proprietário5 & Proprietário8 & propose & 48 & 1.500 \\
\hline & Proprietário5 & Proprietário8 & request & 48 & 1.500 \\
\hline \multirow[t]{2}{*}{14} & Proprietário3 & Proprietário2 & propose & 6 & 600 \\
\hline & Proprietário3 & Proprietário2 & request & 6 & 600 \\
\hline
\end{tabular}

Tabela 67: Negociações Bilaterais de Compra/Aluguel no Jogo-Teste 3 com JM na Rodada 1.

\begin{tabular}{|c|c|c|c|c|}
\hline \hline \multicolumn{5}{|c|}{ JM - Jogo-Teste 3 - Rodada 2 } \\
\hline & Prefeito/AguaPura & Quem solicita & Tipo & Lote \\
\hline \hline 1 & AguaPura & Proprietário6 & need_water & 22 \\
\hline \hline
\end{tabular}

Tabela 68: Negociações Bilaterais de Infra-estrutura no Jogo-Teste 3 com JM na Rodada 2. 


\begin{tabular}{|c|c|c|c|c|}
\hline \hline \multicolumn{5}{|c|}{ JM - Jogo-Teste 3 - Rodada 3 } \\
\hline & Prefeito/AguaPura & Quem solicita & Tipo & Lote \\
\hline \hline 1 & PrefeitoA & AguaPura & need_sanitation & 1 \\
\hline 2 & PrefeitoB & Proprietário6 & need_water & 22 \\
\hline 3 & PrefeitoC & AguaPura & need_water & 46 \\
\hline 4 & AguaPura & SemTeto & need_water & 46 \\
\hline
\end{tabular}

Tabela 69: Negociações Bilaterais de Infra-estrutura no Jogo-Teste 3 com JM na Rodada 3.

\begin{tabular}{|c|c|c|c|c|}
\hline \hline \multicolumn{5}{|c|}{ JM - Jogo-Teste 3 - Rodada 4 } \\
\hline & Prefeito/AguaPura & Quem solicita & Tipo & Lote \\
\hline \hline 1 & PrefeitoB & AguaPura & need_sanitation & 39 \\
\hline 2 & PrefeitoC & SemTeto & need_water & 46 \\
\hline 3 & AguaPura & PrefeitoB & need_sanitation & 39 \\
\hline 4 & PrefeitoB & AguaPura & need_sanitation & 39 \\
\hline \hline
\end{tabular}

Tabela 70: Negociações Bilaterais de Infra-estrutura no Jogo-Teste 3 com JM na Rodada 4.

\begin{tabular}{|c|c|c|}
\hline \hline \multicolumn{3}{|c|}{ JM - Jogo-Teste 3 - Rodada 1 } \\
\hline & Ação & A quem solicita \\
\hline \hline 1 & search_plots & Proprietários $2,8,9$ \\
\hline
\end{tabular}

Tabela 71: Negociações Bilaterais Específicas do Representante dos SemTeto no Jogo-Teste 3 com JM na Rodada 1.

\begin{tabular}{|c|c|c|}
\hline \hline \multicolumn{3}{|c|}{ JM - Jogo-Teste 3 - Rodada 2 } \\
\hline & Ação & A quem solicita \\
\hline \hline 1 & help & Proprietário6 \\
\hline
\end{tabular}

Tabela 72: Negociações Bilaterais Específicas do Representante dos SemTeto no Jogo-Teste 3 com JM na Rodada 2.

\begin{tabular}{|c|c|c|}
\hline \hline \multicolumn{3}{|c|}{ JM - Jogo-Teste 3 - Rodada 4 } \\
\hline & Ação & A quem solicita \\
\hline \hline 1 & search_plots & Proprietários $1,2,8,9$ \\
\hline \hline
\end{tabular}

Tabela 73: Negociações Bilaterais Específicas do Representante dos SemTeto no Jogo-Teste 3 com JM na Rodada 4. 


\begin{tabular}{|l|c|c|c|c|}
\hline \hline \multicolumn{5}{|c|}{ JM - Jogo-Teste 3 - Rodada 1 } \\
\hline Estratégia & Propor & Aceitar & Rejeitar & C-Proposta \\
\hline \hline 1 - Ampliar rede de água & $1,5,6,9$ & $5, \mathrm{~A}, \mathrm{C}$ & & \\
\hline 2 - Ampliar rede de esgoto & 3,6 & $1,9, \mathrm{C}, \mathrm{AP}$ & & \\
\hline $\begin{array}{l}\text { 4 - Ações que incentivam o uso da } \\
\text { área urbana de meu município }\end{array}$ & $2,4,8$ & AP & & \\
\hline $\begin{array}{l}5 \text { - Delimitar a área rural de } \\
\text { meu município: Lotes 57,58 }\end{array}$ & 6 & AP & & \\
\hline $\begin{array}{l}\text { 7 - Insenção gradual de impostos } \\
\text { aos menos poluentes }\end{array}$ & 3,5 & 3,6 & AP & \\
\hline $\begin{array}{l}\text { 10 - Limitar áreas residenciais } \\
\text { para Sem Teto }\end{array}$ & 6 & & & \\
\hline \hline
\end{tabular}

Tabela 74: Negociações Coletivas no Jogo-Teste 3 com JM na Rodada 1.

\begin{tabular}{|l|c|c|}
\hline \hline \multicolumn{2}{|c|}{ JM - Jogo-Teste 3 - Rodada 1 } \\
\hline Estratégia & Jogador Aceitou & Ações Executadas Posterior. \\
\hline \hline 1 - Ampliar rede de água & A,C & C: Água em lote 52 \\
\hline 2 - Ampliar rede de esgoto & C,AP & C: Esgoto em lote 61 \\
\hline $\begin{array}{l}4 \text { - Ações que incentivam o } \\
\text { uso da área urbana de meu } \\
\text { município }\end{array}$ & AP & \\
\hline $\begin{array}{l}5 \text { - Delimitar a área rural de } \\
\text { meu município: Lotes } 57,58\end{array}$ & AP & - \\
\hline
\end{tabular}

Tabela 75: Estratégias Coletivas Aceitas na Rodada 1 e Ações Executadas em Rodadas Posteriores no Jogo-Teste 3 com JM.

\begin{tabular}{|c|c|c|}
\hline \multicolumn{3}{|c|}{ JM - Jogo-Teste 3 - Rodada 2} \\
\hline Estratégia & Jogador Aceitou & Ações Executadas Posterior. \\
\hline 1 - Ampliar rede de água & $\mathrm{C}, \mathrm{AP}$ & $\begin{array}{l}\text { C: Água em lote } 52 \\
\text { AP: }\end{array}$ \\
\hline 2 - Ampliar rede de esgoto & $\mathrm{B}, \mathrm{AP}$ & $\begin{array}{c}\text { B: Esgoto em lotes } 30,32,40 \\
\text { AP: }\end{array}$ \\
\hline $\begin{array}{l}6 \text { - Ações que incentivam } \\
\text { o uso da área rural de meu } \\
\text { município }\end{array}$ & $\mathrm{AP}$ & - \\
\hline
\end{tabular}

Tabela 76: Estratégias Coletivas Aceitas na Rodada 2 e Ações Executadas em Rodadas Posteriores no Jogo-Teste 3 com JM. 


\begin{tabular}{|l|c|c|}
\hline \hline \multicolumn{2}{|c|}{ JM - Jogo-Teste 3 - Rodada 2 } \\
\hline Estratégia & Jogador Aceitou & Ações Executadas Posterior. \\
\hline \hline 1 - Ampliar rede de água & AP & Esgoto em lote 4 \\
\hline 2 - Ampliar rede de esgoto & A & Redução imposto Floresta \\
\hline $\begin{array}{l}\text { 4 - Ações que incentivam o } \\
\text { município área urbana de meu }\end{array}$ & AP & $\begin{array}{c}\text { B: Água e esgoto } \\
\text { em lote 14 (invadido) } \\
\text { AP: }\end{array}$ \\
\hline $\begin{array}{l}\text { 6 - Ações que incentivam área rural de meu } \\
\text { município }\end{array}$ & A \\
\hline $\begin{array}{l}\text { 8 - Prefeitos auxiliam os } \\
\text { SemTeto }\end{array}$ & B,AP & \\
\hline
\end{tabular}

Tabela 77: Estratégias Coletivas Aceitas na Rodada 3 e Ações Executadas em Rodadas Posteriores no Jogo-Teste 3 com JM.

poder de alterar o coletivo aceitaram estratégias coletivas: Prefeitos A, B e C e Administrador da AguaPura. Destes jogadores, apenas o jogador no papel do Prefeito C, que era um jogador virtual, executou as ações relativas às estratégias coletivas aceitas. Dentre os jogadores reais que aceitaram estratégias coletivas, o Administrador da AguaPura foi o que mais negociou e o que menos agiu para colocar em prática as negociações coletivas firmadas.

Este jogo-teste com JM teve apenas 6 jogadores virtuais e 8 jogadores reais, e de acordo com o questionário pré-jogo dos jogadores reais, estes eram o grupo de teste onde os jogadores tinham maior experiência com jogos do tipo RPG. Pelos valores das variáveis a nível global, os jogadores reais tiveram influência negativa no conjunto de ações globais. O Representante dos SemTeto influenciou de forma decisiva na poluição do reservatório e no percentual de desemprego na região, pois não efetivou nenhuma compra/aluguel de lotes durante todo o jogo, tendo sempre alocado as novas famílias em favelas.

Novamente, os jogadores virtuais interagiram de forma ampla e eficiente com todos os outros jogadores, tanto na fase 1 quanto na fase 2 (coletiva), executando corretamente suas ações.

\subsubsection{Análise dos Jogos-Teste com JM}

A partir dos três jogos-teste realizados com JM, pode-se verificar que o protótipo ViP-JogoMan ofereceu aos jogadores sensação de interação, divertimento e aprendizado. Isto se confirma pelas respostas dos jogadores nos questionários pós-jogo e pela análise da troca de mensagens tanto para as negociações 
bilaterais quanto para as negociações coletivas.

Os jogos-teste com JM tinhas dois objetivos principais:

1. Verificar se cada tipo de jogador virtual (perfis comportamentais) teve tomada de decisão apropriada durante os jogos-teste;

2. Verificar se com a inclusão dos jogadores virtuais, as negociações e interações para tomada de decisão continuaram ocorrendo entre todos os tipos de jogadores (reais ou virtuais).

Relacionado ao primeiro objetivo, pode-se concluir pela análise das variáveis dos perfis comportamentais de cada jogo-teste que os jogadores virtuais executaram suas ações de acordo com os objetivos definidos para cada tipo de perfil comportamental. Pelas respostas dos questionários pós-jogo, pode-se perceber que a maioria dos jogadores virtuais não foram facilmente descobertos pelos jogadores reais. Na verdade, o que fez com que alguns dos jogadores virtuais fossem descobertos foi a velocidade de suas respostas durante as negociações e não a forma com que interagiam com os outros jogadores. Quando os JH foram realizados, alguns jogadores afirmaram que haviam jogadores virtuais nos jogosteste e os motivos expressos para tal afirmação foram exatamente os mesmos que os apresentados nos JM: velocidade de resposta durante as negociações ou porque as ações executadas eram ditas muito "corretas". Isso confirma que a tomada de decisão dos jogadores virtuais foi parecida a dos jogadores reais, gerando dúvidas de sua presença no jogo ou não.

Quanto ao segundo objetivo deste tipo de jogo-teste, pode-se concluir que os jogadores virtuais interagiram de forma ampla com os jogadores reais. Em alguns casos, foram até elogiados pelas suas ações (caso do Representante dos SemTeto no jogo-teste 1). Isso também pode ser confirmado pela quantidadade de negociações bilaterais e coletivas em que os jogadores virtuais participaram. Por exemplo, no jogo-teste 1 com JM, a maioria das negociações bilaterais foi iniciada por jogadores virtuais. Contudo, não se pode concluir que os jogadores virtuais aumentaram, de uma forma global, o número de negociações entre os jogadores, pois nos jogos-teste 2 e 3 com JM, o número de negociações, sejam bilaterais ou coletivas, foi menor do que nos jogos-teste 2 e 3 com JH, onde não haviam jogadores virtuais.

Outro aspecto que foi muito importante nestes jogos-teste foi a influência de cada um dos papéis do jogo na evolução global da região. Quando jogadores virtuais executaram papéis ditos de maior importância no jogo, como de admi- 
nistrador da AguaPura e de Representante dos SemTeto (no primeiro e segundo jogos-teste), a situação global da região evoluiu de forma menos caótica que no terceiro jogo-teste, onde jogadores reais executaram estes papéis. Isto se confirma pela análise de variáveis globais, como o Índice de Poluição do Reservatório dos três jogos-teste. Este aspecto é um dos objetivos da tese: mostrar que as ações de cada jogador podem influenciar todo o sistema e que determinadas ações podem ser executadas, apresentando novas possibilidades, novas visões de jogo.

Nos jogos-teste 1 e 2, onde o papel de Administrador da AguaPura foi executado por um jogador virtual, descobriu-se que a base de conhecimento para este papel está incompleta, para os dois perfis comportamentais definidos. No caso do perfil comportamental com interesse protetor-ambientalista, no jogo-teste 1, este aceitou a estratégia coletiva 2 - Ampliar a rede de esgoto na rodada 2 e não executou nenhuma ação neste sentido posteriormente. Já no jogo-teste 2 , na rodada 1 , o perfil comportamental com interesse racional aceitou a estratégia 9 - Incentivo a construção de novas indústrias na região urbana para geração de empregos e também não executou nenhuma ação neste sentido. É necessário reavaliar a base de crenças, desejos e intenções destes dois tipos de perfis comportamentais para que estes executem as ações propostas de forma integral, dentro dos objetivos pré-definidos para cada perfil comportamental.

Os jogadores propuseram melhorias ao jogo, a partir das respostas dos questionários pós-jogo. As principais melhorias/críticas apresentadas pelos jogadores foram:

- Reduzir a fase 2 (coletiva) e aumentar a fase 1 ;

- Apresentar os gráficos da evolução global do sistema ao final de cada uma das rodadas do jogo, para que a evolução fique mais clara no decorrer do jogo;

- Identificar cada jogador por uma foto (figura) para facilitar a negociação;

- Melhorar a interface gráfica, principalmente relacionado ao envio e ao recebimento de mensagens, para que seja mais intuitiva. Um dos jogadores sugeriu um sistema de cores, onde cada jogador tem uma cor e assim ficaria mais fácil identificar as mensagens recebidas de cada jogador. 


\subsection{Considerações Finais}

Este capítulo apresentou os testes realizados com o protótipo ViP-JogoMan. Foram realizados três tipos diferentes de jogos-teste com este protótipo: Jogos Exclusivamente com Jogadores Virtuais (JV), Jogos Exclusivamente com Jogadores Humanos (JH) e Jogos com Jogadores Mistos (JM). Para realizar a análise destes jogos-teste, foram utilizadas três formas de avaliação: análise de questionários aos jogadores reais, de variáveis definidas para cada perfil comportamental e de troca de mensagens entre jogadores.

Os questionários pré e pós-jogo deram uma grande quantidade de informações qualitativas sobre os jogadores, seu entendimento do jogo, objetivos de cada jogador e sugestões e críticas sobre o protótipo. Todas essas informações são muito utéis na avaliação do sistema como um todo.

As variáveis definidas para cada perfil comportamental mediram, de forma quantitativa, o desempenho de cada um dos perfil comportamentais definidos, perante os outros jogadores, sejam eles reais ou virtuais.

Já a análise de troca de mensagens entre os jogadores mediu quantitativamente as negociações realizadas por todos os jogadores e se as interações ocorreram de forma ampla. Diferentemente dos jogos de mesa, onde apenas as ações finais de compra/aluguel são registradas ${ }^{10}$, nos jogos realizados com o protótipo ViP-JogoMan pode-se acompanhar todo o processo de negociação dos jogadores, inclusive as negociações não concluídas ou rejeitadas. Desta maneira, entende-se melhor o processo de negociação realizado pelos jogadores durante o jogo.

Já para as negociações coletivas, negociadas na "Reunião do Comitê de Bacia" dos jogos de mesa, as únicas informações armazenadas são as respostas para a questão 8 do questionário pós-jogo ${ }^{11}$. No caso do ViP-JogoMan, têm-se, além das respostas a esta questão, todas as informações que cada jogador propôs, aceitou, rejeitou ou contra-propôs para cada uma das estratégias coletivas definidas ${ }^{12}$. Desta forma, pode-se definir os objetivos de cada jogador, suas preocupações e futuras metas, ajudando a melhor entender cada jogador.

A Tabela 78 apresenta a quantidade de negociações bilaterias e coletivas realizadas para os seis jogos-teste que envolveram jogadores humanos (3 jogos-teste com JH e 3 jogos-teste com JM).

\footnotetext{
${ }^{10}$ Ver dados no Anexo B.

${ }^{11}$ Ver dados no Anexo A.

${ }^{12}$ Ver dados no Anexo D.
} 


\begin{tabular}{|c|c|c|c|}
\hline \hline Tipo & Número & Negociações Bilaterais & Negociações Coletivas \\
\hline \hline JH & 1 & 29 compra/aluguel & 74 \\
& & 17 infra-estrutura & 77 \\
\hline JH & 2 & 20 compra/aluguel & 90 \\
& & 36 infra-estrutura & \\
\hline JH & 3 & $\begin{array}{c}11 \text { infra-estrutura } \\
3 \text { busca por lote }\end{array}$ \\
& & 53 compra/aluguel & 136 \\
& & 10 infra-estrutura & 59 \\
\hline \hline JM & 1 & 8 infra-estrutura & 112 \\
& & 25 compra/aluguel & \\
\hline JM & 2 & 3 busca por lote & \\
\hline JM & 3 & \multicolumn{2}{|}{} \\
& & & \\
\hline \hline
\end{tabular}

Tabela 78: Quantidade de Negociações Bilaterais e Coletivas nos JH e JM.

Pelos valores indicados na Tabela 78, verifica-se que, em sua maioria, o número de negociações bilaterais e coletivas aumentou nos JM. Isso prova que a inserção de jogadores virtuais amplia (ou "força") o processo de negociação. Assim, os jogadores reais participam mais amplamente deste processo, auxiliando no aprendizado do domínio que o jogo propõe.

Pode-se concluir que os todos os tipos de jogos-teste realizados foram extremamente importantes em todo o processo de desenvolvimento do protótipo ViP-JogoMan e que cada tipo de jogo-teste atingiu os objetivos propostos. Com a realização destes testes, pode-se ter um melhor entendimento do uso da arquitetura ViP-GMABS, objetivo principal desta tese. 


\title{
11 Conclusões
}

\author{
"Os afortunados não são necessariamente os que têm o melhor \\ do melhor. Mas, buscam o melhor daquilo que encontram em seu \\ caminho."(Autor Desconhecido)
}

Este trabalho propôs uma arquitetura para incorporar Jogadores Virtuais em Sistemas de Apoio à Decisão em Grupos (SADs-G) utilizando a metodologia GMABS, denominada ViP-GMABS. Foi implementada uma instância desta arquitetura, no contexto da gestão dos recursos naturais, denominada ViP-JogoMan. Esta instância foi utilizada para testes e análise, a fim de validar a arquitetura ViP-GMABS e alcançar o objetivo principal da tese, de definir jogadores virtuais com comportamento similar ao comportamento de jogadores reais e que estes jogadores virtuais pudessem apresentar novas visões do jogo aos jogadores reais. Pode-se concluir que os jogadores virtuais atenderam a este objetivo, sendo utilizados com eficiência nos jogos-testes realizados.

A seguir, apresentam-se respectivamente nas seções 11.1 e 11.2 as contribuições deste trabalho e algumas possíveis extensões futuras.

\subsection{Contribuições}

Na seção 1.4, algumas questões foram levantadas para o entendimento e a utilização de jogadores virtuais em GMABS. Retomando estas questões, apresentamse a seguir as respostas que destacam as principais contribuições desta tese:

- Como podem ser definidos os comportamentos de cada jogador virtual, de forma que estes tenham tomada de decisão parecida com a dos jogadores reais?

A utilização da arquitetura BDI e definição de perfis comportamentais diferentes para os tipos de papéis do jogo permitiu aos jogadores virtuais exibir comportamentos com tomada de decisão bastante parecida aos dos jogadores reais. 
Nos jogos-teste com JM, a maioria dos jogadores virtuais não foi percebida pelos jogadores reais durante os jogos. Em alguns casos, os jogadores reais elogiaram a forma de negociação/interação de jogadores virtuais (sem saber que eram jogadores virtuais), como no caso do representante dos SemTeto, no primeiro jogo-teste com JM. Na verdade, a tomada de decisão dos jogadores virtuais não foi questionada pelos jogadores reais, pois os jogadores reais que perceberam a existência de jogadores virtuais basearam suas afirmações na velocidade que os jogadores virtuais respondiam às propostas durante as negociações. Em alguns casos, entretanto, os jogadores reais indicaram como jogadores virtuais outros jogadores reais, pelo mesmo motivo.

O fato das negociações utilizarem um chat de troca de mensagens fechado fez com que os jogadores virtuais não fossem facilmente percebidos pelos jogadores reais. Se um sistema de negociação aberto fosse utilizado, onde qualquer texto pudessem ser enviado aos jogadores, provavelmente seria necessário utilizar algum algoritmo de processamento de linguagem natural para os jogadores virtuais.

O fato dos perfis comportamentais dos jogadores virtuais terem sido definidos a partir de informações de jogos de mesa, utilizando dados colhidos dos jogos-teste do protótipo JogoMan, e consequentemente, de ações de jogadores reais, ajudou no desenvolvimento de perfis comportamentais verossímeis.

Desta maneira, a primeira contribuição do trabalho foi a utilização da arquitetura BDI e dos perfis comportamentais para modelar a tomada de decisão dos jogadores virtuais, fazendo com que esta fosse parecida a dos jogadores reais.

- Diversos trabalhos mostram a capacidade de discussão e aprendizado de técnicas de RPG (BARRETEAU et al., 2004; D'AQUINO et al., 2003; DARE; BARRETEAU, 2004; GUYOT; DROGOUL, 2005). Com a inserção de jogadores virtuais, esta capacidade continuará ativa? As negociações e interações para tomada de decisão continuarão ocorrendo entre os jogadores reais e/ou virtuais?

Para que esta pergunta pudesse ser respondida foi necessário realizar os dois tipos de jogos-teste via $W e b$ : jogos exclusivamente com jogadores humanos (JH) e jogos com jogadores mistos (JM). Os JH não envolviam jogadores virtuais e se queria medir a influência da tecnologia (computador) na reali- 
zação do jogo. Se os jogadores reais conseguissem interagir de forma ampla nos jogos-teste com JH, quando houvesse a inserção de jogadores virtuais nos jogos-teste com JM se poderia então medir a influência dos jogadores virtuais no processo de negociação/interação entre os jogadores.

Analisando quantativamente as negociações bilaterais e coletivas dos jogosteste com JH e com JM, pode-se verificar que a inserção de jogadores virtuais, na maioria das vezes, ampliou o processo de negociação, aumentando o número de propostas trocadas entre os jogadores.

Quanto à capacidade de discussão e aprendizado das técnicas de RPG, pelas respostas dadas pelos jogadores reais nos questionários pós-jogo conclui-se que nos jogos-teste com JM esta capacidade continuou presente. Observase que os jogadores reais entenderam a importância da gestão de recursos naturais e a complexidade de negociação nesta área.

Assim, pode-se afirmar que a segunda contribuição do trabalho foi confirmar que com a inserção de jogadores virtuais as capacidades inerentes dos jogos do tipo RPG continuaram presentes, bem como a interação entre todos os jogadores.

- O protótipo será implementado para ser jogado via Web. Esta forma de jogo (remota) dificultará as interações entre os jogadores (reais ou virtuais)? Haverá dificuldade dos jogadores reais de interagir com o sistema (problemas de interface ou demora na execução das ações remotas)?

Esta questão está relacionada à questão anterior, pois os dois tipos de jogosteste realizados, JH e JM, foram realizados via Web e as negociações deveriam acontecer de forma ampla, onde a tecnologia (computador) não interferisse neste processo.

Como já apresentado anteriormente, diversos trabalhos mostram que negociações via Internet têm vantagens, se comparadas a negociações face-a-face (MCKERSIE; FONSTAD, 1997; KERSTEN; NORONHA, 1999; PEPPET, 2002; ES; FRENCH; STELLMAZEK, 2004). A principal vantagens é um "mapeamento" completo de todas as negociações realizadas, independente de serem completadas ou não. Isso permite definir com maior precisão os jogadores e seus objetivos. Pelos dados dos jogos-testes, tanto para as negociações bilaterais como para as coletivas, verifica-se um número de interações superior ao dos jogos de mesa realizados.

No que diz respeito as dificuldades dos jogadores de interagir com o sistema, pode-se verificar pelas respostas dos questionários pós-jogo que al- 
gumas alterações na interface do protótipo, principalmente relacionado à apresentação das mensagens enviadas e recebidas, devem ser realizadas. Quanto à demora na execução das ações remotas, o grande problema esteve relacionado à inicialização do Applet Java na primeira rodada, visto que nas rodadas seguintes não era necessário realizar atualizações constantes, diminuindo os problemas com desempenho.

Desta forma, a terceira contribuição deste trabalho foi verificar que a Internet não é um problema para a realização de jogos do tipo RPG, mas sim uma nova ferramenta para que estes tipos de jogos possam ser realizados. Contudo, deve-se projetar as interfaces de forma que as informações necessárias aos jogadores sejam disponibilizadas de forma prática e rápida.

Adicionalmente, 9 publicações foram geradas durante os trabalhos desenvolvidos como parte da elaboração esta dtese. As publicações estão relacionadas às diferentes atividades descritas na metodologia (seção 1.3):

- Aplicação da metodologia GMABS (atividade 1): (ADAMATTI; SICHMAN; DUCROT, 2004);

- Protótipo JogoMan (atividade 2): (ADAMATTI et al., 2005);

- Proposta inicial da inserção de jogadores virtuais na metodologia GMABS (atividade 3): (ADAMATTI; SICHMAN, 2004);

- Definição dos perfis comportamentais para os jogadores virtuais e primeiros testes (atividades 4 e 5): (ADAMATTI; SICHMAN; COELHO, 2006), (ADAMATTI; SICHMAN; COELHO, 2007e) e (ADAMATTI; SICHMAN; COELHO, 2007d);

- Protótipo ViP-JogoMan (atividades 6 e 7): (ADAMATTI; SICHMAN; COELHO, 2007a), (ADAMATTI; SICHMAN; COELHO, 2007c) e (ADAMATTI; SICHMAN; COELHO, 2007b).

\subsection{Trabalhos Futuros}

Este trabalho apresentou resultados bastante interessantes e promissores. Entretanto, alguns problemas foram encontrados e poderiam ser solucionados em extensões possíveis deste trabalho, bem como novos caminhos poderiam ser explorados, tais como: 
- Desenvolver a base de dados dos jogadores virtuais de forma dinâmica, onde novas crenças e novos planos fossem inseridos durante o jogo, ao final de cada rodada. Isso traria maior realismo ao jogo, visto que jogadores reais agem desta forma: no decorrer do jogo vão entendendo melhor as regras, os outros jogadores, a influência de cada ação no ambiente, e assim mudam suas ações, com intuito de alcançar seus objetivos. Técnicas de Aprendizado de Máquina, como algoritmos genéticos ou redes neurais, poderiam ser utilizadas para gerar estas novas crenças e planos de forma automática, buscando as informações nos arquivos de Log ao final de cada rodada;

- Desenvolver planos que envolvam emoções, para que os jogadores virtuais tenham reações emocionais distintas em diferentes planos de sua base de dados. O modelo proposto por Ortony et. al (ORTONY; CLORE; COLLINS, 1988) poderia ser utilizado, visto que é um modelo proposto por psicólogos para implementação de emoções em máquinas. Com a utilização de emoções, as ações dos jogadores virtuais também ser tornariam mais realistas;

- Utilizar um algoritmo de processamento de linguagem natural para os jogadores virtuais, para que o sistema de negociação pudesse ser aberto, onde os jogadores pudessem escrever suas mensagens. A implementação deste recurso certamente traria ao sistema uma veracidade ainda maior sobre os objetivos, idéias e problemas de cada jogador;

- Utilizar ontologias na camada de comunicação (definida na arquitetura ViPGMABS), fazendo com que a comunicação fosse padronizada e homogênea. Com isto, um "dicionário" do domínio proposto seria criado, o que facilitaria uma análise mais completa do processo de negociação entre os jogadores e a própria implementação de um algortimo de processamento de linguagem natural;

- Utilizar algum sistema de temporização para os jogadores virtuais. Pelos jogos-teste realizados, a velocidade de resposta durante a tomada de decisão dos jogadores virtuais foi um fator que possibilitou, em alguns casos, a descoberta destes jogadores. Com a utilização métricas para determinar o "tempo de resposta" destes jogadores, talvez sua utilização torne-se ainda mais transparente;

- Melhorar a interface do protótipo ViP-JogoMan, tornando-a mais dinâmica, com mais recursos gráficos, principalmente na apresentação de dados do jogo. Uma nova forma de apresentar as mensagens enviadas e recebidas 
deve ser desenvolvida. Alguns jogadores sugeriram utilizar um sistema de cores, separação de mensagens por tipo ou por jogador em modelos do tipo árvore (como o Windows Explorer apresenta os diretórios do computador). Também sugeriram a inclusão de figuras para cada jogador, auxiliando a identificá-los;

- Do ponto de vista de implementação, dois outros aspectos poderiam ser melhorados:

- Poucos jogadores comentaram em seus questionários pós-jogo, mas foi percebido durante os jogos-teste que a interface do protótipo ViPJogoMan demora um pouco para ser iniciada na primeira rodada. O protótipo foi implementado em Java e na primeira rodada ele necessita recuperar do servidor diversos arquivos com extensão .jar necessários para a utilização do protocolo SOAP, que não estão disponíveis nas versões do Java padrão. Como os Applets Java sempre são executados locamente na máquina do usuário, é necessário realizar está transferência de dados na primeira rodada. Assim, a implementação dos Applets Java deve ser o mais "leve" possível, para que não seja necessário definir uma banda de comunicação mínima ou configuração de hardware mínimo no computador do usuário;

- O protótipo ViP-JogoMan foi testado para utilização em dois browsers: Internet Explorer e Mozilla Firefox. No caso do segundo browser, diversos usuários estavam utilizando o sistema operacional Linux. Em teoria, implementações em Java poderiam ser executadas para qualquer sistema operacional ou em qualquer browser. Contudo, o protótipo foi testado apenas para os browsers citados e para os sistemas operacionais Windows e Linux. Versões para outros navegadores poderiam ser disponibilizadas. 


\section{Anexos em CD}

ANEXO A: Questionários Aplicados no JogoMan

ANEXO B: Dados Extraídos dos Jogos Realizados no JogoMan

ANEXO C: Definição das Justificativas das Negociações Bilaterais no ViPJogoMan

ANEXO D: Definição das Estratégias Coletivas no ViP-JogoMan

ANEXO E: Dados Extraídos dos Jogos Realizados no ViP-JogoMan 


\title{
Referências Bibliográficas
}

\author{
ADAMATTI, D. F.; SICHMAN, J.; DUCROT, R. Using multi-agent systems \\ and role-playing games to simulate water management in peri-urban catchments. \\ In: GILBERT, N.; TROITZSCH, K. G. (Ed.). Sixth International Conference \\ on Social Science Methodology. Amsterdam: Social Science Methodology, 2004. \\ CD-ROM.
}

ADAMATTI, D. F.; SICHMAN, J. S. Inserção de jogadores virtuais em jogo de papéis no contexto de gestão de recursos naturaiss. In: ALVARES, L. O. (Ed.). Workshop de Teses e Dissertações em Inteligência Artificial WTDIA 2004. São Luís, Maranhão - Brasil: SBC, 2004. p. 31. Poster.

ADAMATTI, D. F. et al. JogoMan: A prototype using multi-agent-based simulation and role-playing games in water management. In: FERRAND, N. (Ed.). Join Conference on Multi-Agent Modeling for Environmental Management. CABM-HEMA-SMAGET. Bourg-Saint-Maurice, Les Arcs, France: IRD, 2005. CD-ROM.

ADAMATTI, D. F.; SICHMAN, J. S.; COELHO, H. Jogadores virtuais em jogos de papéis. In: RAMALHO, G. (Ed.). V Brazilian Symposium on Computer Games and Digital Entertainment (SBGAMES 2006). Recife - Pernambuco, 2006. CD-ROM.

ADAMATTI, D. F.; SICHMAN, J. S.; COELHO, H. Inserção de jogadores virtuais na metodologia gmabs: uma aplicação em gestão de recursos naturais. In: DUTRA, I. (Ed.). Encontro Nacional de Inteligência Artificial 2007 (ENIA2007). Rio de Janeiro: SBC, 2007. To appear.

ADAMATTI, D. F.; SICHMAN, J. S.; COELHO, H. Using virtual players in gmabs methodology: a case study in natural resources management. In: AMBLARD, F. (Ed.). The Fourth European Social Simulation Association Conference (ESSA 2007). Toulosse, France: ESSA, 2007.

ADAMATTI, D. F.; SICHMAN, J. S.; COELHO, H. Utilização de rpg e mabs no desenvolvimento de sistemas de apoio à decisão em grupos. In: GEROSA, M. (Ed.). Simpósio Brasileiro de Sistemas Colaborativos 2007 (SBSC2007). Rio de Janeiro: SBC, 2007. To appear.

ADAMATTI, D. F.; SICHMAN, J. S.; COELHO, H. Virtual players: From manual to semi-autonomous RPG. In: FRYDMAN, C. (Ed.). AI, Simulation and Planning in High Autonomy Systems (AIS) and Conceptual Modeling and Simulation (CMS). Join to International Modeling and Simulation Multiconference 2007 (IMSM07). Buenos Aires - Argentina, 2007. p. 159-164.

ADAMATTI, D. F.; SICHMAN, J. S.; COELHO, H. Virtual players in RPG. In: HUANG, T. S. et al. (Ed.). International Workshop on AI for Human Computing (IJCAI 2007). Hyderabad, India, 2007. 
AGAR, S. Artificial Intelligence and Diplomacy. March 1994. Www.diplomacyarchive.com/resources/postal/artificial.html. Accessed in July 2005.

ALCHIERI, J. C.; CRUZ, R. M. Avaliação Psicológica - Conceitos, Métodos e Instrumentos. $1^{\mathrm{a}}$ edição. ed. São Paulo - Brasil: Casa do Psicólogo, 2003.

ALVARES, L. O. C.; SICHMAN, J. S. Introdução aos sistemas multiagentes. In: SOCIEDADE BRASILEIRA DE COMPUTACÃO. Jornada De Atualização Em Informática. Brasília - UnB, 1997. p. 1-37.

ANDERSON, J.; MATESSA, M. The rational analysis of categorization and the ACT-R architecture. In: OAKSFORD, M.; CHATER, N. (Ed.). Rational Models of Cognition. Oxford: Oxford Univertisy Press, 1998.

ANDERSON, J. R. A simple theory of complex cognition. American Psychologist, v. 51, n. 4, p. 355-365, April 1996.

ANDERSON, J. R. et al. Production system models of complex cognition. In: Proceedings of the Seventeenth Annual Conference of the Cognitive Science Society. Hillsdale, NJ: Lawrence Erlbaum Associates, 1995. p. 9-12.

ANDERSON, J. R.; LEBIERE, C. The atomic components of thought. Mahwah, NJ: Erlbaum, 1998.

ANDERSON, J. R.; SCHUNN, C. D. Implications of the ACT-R learning theory: No magic bullets. In: GLASER, R. (Ed.). Advances in instructional psychology. Mahwah, NJ: Erlbaum, 2000. v. 5.

ANTUNES L. BALSA, J.; COELHO, H. Agents that collude to evade taxes. In: DURFEE, E. H. (Ed.). International Conference on Autonomous Agents and Multiagent Systems (AAMAS 2007). Honolulu, Hawai: ACM, 2007.

AVOLIO, B. et al. Virtual teams: Implications for e-leadership and team development. In: LONDON, M. (Ed.). How People Evaluate Others in Organizations. Mahwah, New Jersey: Lawrence Erlbaum Associates, 2001.

BANDINI, S.; MANZONI, S.; VIZZARI, G. RPG-Profiler: a MAS for Role Playing Games Based Tests in Employee Assessment. Università di Milano-Bicocca, Italia: Springer Verlag, 2002. WOA 2002.

BANNON, L. Design at Work - Chapter: From Human Factors to Human Actors: The Role of Psychology and HCI Studies in System Design. Hillsdale, New Jersey: Lawrence Erlbaum, 1991. 25-44 p.

BARRETEAU, O. The joint use of role-playing games and models regarding negotiation processes: characterization of associations. JASSS, v. 6, n. 2, March 2003. Http://jasss.soc.surrey.ac.uk/6/2/3.html.

BARRETEAU, O.; BOUSQUET, F.; ATTONATY, J. Role-playing games for opening the black box of multi-agent systems: method and lessons of its application to Senegal River Valley irrigated systems. JASSS, v. 4, n. 2, March 2001. Http://www.soc.surrey.ac.uk/JASSS/4/2/5.html.

BARRETEAU, O. et al. Suitability of multi-agent simulations to study irrigated system viability: Application to case studies in the segal river valley. Agricultural Systems, v. 80, n. 3, p. 255-275, June 2004. 
BARRETEAU, O.; PAGE, C. L.; D'AQUINO, P. Role-playing games, models and negotiation. JASSS, v. 6, n. 2, March 2003. Http://jasss.soc.surrey.ac.uk/6/2/10.html.

BECK, E. E.; BELLOTTI, V. Informed opportunism as strategy: supporting coordination in distributed collaborative writing. In: European Conference on Computer-Supported Cooperative Work (ECSCW). Milano: Kluwer Academic Publishers, 1993. p. 233-248.

BIANCHINI, R. Uma arquitetura BDI para comportamentos interativos de agentes em jogos computacionais tridimensionais. Tese (Tese de doutorado) Escola Politécnica da Universidade de São Paulo, São Paulo, 2005.

BISPO, C. A. F. Uma Análise da Nova Geração de Sistemas de Apoio à Decisão. Dissertação (Mestre em Engenharia de Produção) - Universidade de São Paulo, São Carlos - SP, 1998.

BITTENCOURT, G. Inteligência artificial distribuída. In: CTA/ITA. WORKSHOP DE COMPUTAÇÃO (WORKCOMP). São José dos Campos, 1998.

BOISSAU, S.; CASTELLA, J. Constructing a common representation of local institutions and land use systems through simulation-gaming and multiagnet modelling in rural areas of northern vietnam: The SAMBA-Week methodology. Simulation 83 Gaming, v. 34, n. 3, p. 342-357, September 2003.

BORDINI, R.; HUBNER, J. JASON: A Java-based AgentSpeak interpreter used with Saci for multi-agent distribution over the Net. 2004. Http://jason.sourceforge.net/.

BORDINI, R. H. et al. AgentSpeak(XL): Efficient intention selection in BDI agents via decision-theoretic task scheduling. In: CASTELFRANCHI, C.; JOHNSON, W. L. (Ed.). International Joint Conference on Autonomous Agents and Multi-Agent Systems (AAMAS-2002). Bologna, Italy: ACM Press, 2002. p. $1294-1302$.

BORDINI, R. H. et al. Model checking agentspeak. In: ROSENSCHEIN, J. S. et al. (Ed.). International Joint Conference on Autonomous Agents and Multi-Agent Systems (AAMAS-2003). Melbourne, Australia: ACM Press, 2003. p. $409-416$.

BORDINI, R. H.; MOREIRA, A. F. Proving BDI properties of agent-oriented programming languages: The asymmetry thesis principles in AgentSpeak(L). Mathematics and Artificial Intelligence, v. 1-3, n. 42, 2004. Special Issue on Computational Logic in Multi-Agent Systems.

BOUSQUET, F. et al. An environmental modelling approach. the use of multi-agent simulations. In: BLASCO, F.; WEILL, A. (Ed.). Advances in environmental and ecological modelling. Paris: Elsevier, 1999. p. 113-122.

BRATMAN, M. E. Intention, Plans and Practical Reason. Cambridge, Massachusets: Harvard University Press, 1987.

BREDEMEIER, M. E.; GREENBLAT, C. S. The educational effectiveness of simulation games. Simulation $\& 6$ Games, v. 12, n. 3, p. 307-333, September 1981. 
BRIOT, J. P.; GUYOT, P.; IRVING, M. Participatory simulation for collective management of protected areas for biodiversity conservation and social inclusion. In: FRYDMAN, C. (Ed.). International Modeling and Simulation Multiconference 2007 (IMSM07). Buenos Aires - Argentina, 2007.

CAMARGO, M. E. S. A. Jogos de Papéis (RPG) em Diálogo com a Educação Ambiental: Aprendendo a Participar da Gestão dos Recursos Hidricos na Região Metropolitana de São Paulo. Dissertação (Mestrado) — Programa de Pós-Graduação em Ciência Ambiental PROCAM - Universidade de São Paulo, São Paulo, 2006.

CARDENAS, J.; OSTROM, E. What do people bring into the game? experiments in the field about cooperation in the commons. Agricultural Systems, v. 82, n. 3, p. 307-326, December 2004.

CARVAlHO, M. N. Inteligência Artificial para Jogos de Tabuleiro. Dissertação (Dissertação de Mestrado) - Instituto de Matemática e Estatística da Universidade de São Paulo, Março 2004.

COMUZZI, M.; PERNICI, B. Negotiation support for web service selection. In: TES 2004. Berlin: Springer-Verlag, 2004. p. 29-38. LNCS 3324.

CORMAS. Natural Resources and Multi-Agent Simulations. 2006. Http://cormas.cirad.fr.

COSTA, C. J. et al. Sistemas de apoio a reuniões: Limitações actuais e oportunidades de disseminação da tecnologia. In: Primeiro Workshop de Sistemas Multimédia Cooperativos e Distribuidos, CoopMedia 2000. Coimbra, Portugal: http://www.di.fc.ul.pt/ paa/papers/coopmedia-00-sala.pdf, 2000.

COSTIKYAN, G. I have no words and I must design. Interactive Fantasy, v. 2, 1994.

CUSTODIO, V. A Questão das Águas na RMSP (Região Metropolitana de São Paulo) - Projeto Educação Ambiental. São Paulo/SP, Dezembro 2004.

DANIELS, M. The Swarm Simulation System - A tool for studying complex systems. 2006. <www.swarm.org >.

D'AQUINO, P. et al. Using self-designed role-playing games and a multi-agent systems to empower a local decision-making process for land use management: The selfcormas experiment in Senegal. JASSS, v. 6, n. 3, June 2003. Http://jasss.soc.surrey.ac.uk/6/3/5.html.

DARE, W.; BARRETEAU, O. Agent-based simulatins backing use of role-playing games as dialogue support tools: Teaching from experiments. In: GILBERT, N.; TROITZSCH, K. G. (Ed.). Sixth International Conference on Social Science Methodology. Amsterdam: Social Science Methodology, 2004.

DENNIS, A. R.; VALACICH, J. V. Conducting research in infromation system. Communications of the Association for Information Systems, v. 7, n. 5, p. 2-24, 2001.

DORAN, J. Intervening to achieve co-operative ecosystem management: Towards an agent based model. JASSS, v. 4, n. 2, March 2001. Http://www.soc.surrey.ac.uk/JASSS/4/2/4.html. 
DORN, D. S. Simulation games: One more tool on the pedagogical shelf. Teaching Sociology, v. 17, n. 1, p. 1-18, January 1989.

DORNELAS, J. S. Impactos da adoção de sistemas de apoio à decisão para grupos em um processo decisório público participativo: o caso do orçamento de Porto Alegre. Tese (Doutor em Administração) — Universidade Federal do Rio Grande do Sul, Porto Alegre, Março 2000.

DOUSE, N.; MCMANUS, I. The personality of fantasy game players. British Journal of Psychology, v. 84, n. 4, p. 505-509, 1993.

DROGOUL, A.; FERBER, J. Multi-agent simulation as a tool for modeling societies: Application to social differentiation in ant colonies. In: Proceedings of Workshop on Modelling Autonomous Agents in a Multi-Agent World (MAAMAW'92). Viterbo: Elsevier North-Holland, 1992.

DUCROT, R. et al. Water management at the urban fringe in metropolitam catchment: Example of the São Paulo upstream catchment (Brasil). In: 5th Internacional Ecocity Conference. Yokohama: UNU/IAS, 2003.

DUCROT, R. et al. Articulating land and water dynamics with urbanization: an attempt to model natural resources management at the urban edge. Computers, environment and urban systems, v. 28, n. 1-2, p. 85-106, 2004.

EDMONDS, B.; BARTHELEMY, O.; MOSS, S. Domestic Water Demand and Social Influence: an agent-based modelling approach. Manchester Metropolitan University Business School, 2002.

EGENFELDT-NIELSEN, S. Review of the Research on Educational Usage of Games. 2004. Http:///itu.dk/people/sen/public.htm.

ELLIS, C. A.; GIBBS, S. J.; REIN, G. Readings in Groupware and ComputerSupported Cooperative Work - Assisting Human-Human Collaboration - Chapter: Group Ware: Some issues and experiences. San Francisco, California: Morgan Kaufamann Publishers, 1993. 9-28 p.

ES, R. V.; FRENCH, W.; STELLMAZEK, F. Resolving conflicts over ethical issues: Face-to-face versus internet negotiations. Journal of Business Ethics, v. 53, n. 1, p. 165-172, 2004.

ETIENNE, M. SYLVOPAST: a multiple target role-playing game to assess negotiation processes in sylvopastoral management planning. JASSS, v. 6, n. 2, March 2003. Http://jasss.soc.surrey.ac.uk/6/2/5.html.

FALSARELLA, O. M.; CHAVES, E. O. Sistemas de Informação e Sistema de Apoio à Decisão. 2003.

Http://www.chaves.com.br/TEXTSELF/COMPUT/sad.htm.

FERBER, J. Multi-Agent Systems - An Introduction to Distributed Artificial Intelligence. London: Addison-Wesley, 1999. 509 p.

FIPA. Communicative Act Library Specification. 2002. Http://www.fipa.org.

FIPA. Contract Net Interaction Protocol Specification. 2002. Http://www.fipa.org. 
FJERMESTAD, J. An analysis of communication mode in group support systems research. Decision Support Systems, n. 37, p. 239-263, 2004. Available online in www.elsevier.com/locate/dsw.

FONSECA, J. M. M. R. d. Protocolos de negociação com coligações em sistemas multi-agente - Uma aplicação à gestão distribuída de recursos. Tese (Especialidade de Robótica e Manufactura Integrada) — Universidade Nova de Lisboa, Faculdade de Ciências e Tecnologia, Lisboa, 2000.

FROZZA, R. SIMULA: Ambiente para Desenvolvimento de Sistemas Multiagentes Reativos. Dissertação (Mestrado) — UFRGS, Universidade Federal do Rio Grande do Sul - Brasil, Rio Grande do Sul, Brasil, 1997.

GENESERETH, M.; LOVE, N.; PELL, B. General game playing: Overview of the AAAI competition. AI Magazine, p. 63-72, June 2005.

GILBERT, N.; TROITZSCH, K. G. Simulation for the Social Scientist. London: Buckingham and Philadelphi: Open University Press, 1999. 255p p.

GUTKNECHT, O.; FERBER, J. The MadKit Project: a Multi-Agent Development Kit. 2006. <http://www.madkit.org/>.

GUYOT, P.; DROGOUL, A. Two sides of emergence in participatory simulations. In: Proceedings of Social Inspired Computing. Hatfield, UK: Engineering and Physical Sciences Research Council, 2005.

GUYOT, P.; DROGOUL, A.; HONIDEN, S. Power and negotiation: Lessons from agent-based participatory simulations. In: International Joint Conference on Autonomous Agents and Multiagent Systems (AAMAS-06). Hakodate: ACM Press, 2006. p. 27-33.

GUYOT, P.; DROGOUL, A.; LEMAîTRE, C. Using emergence in participatory simulations to design multi-agent systems. In: DIGNUM, F. e. a. (Ed.). International Joint Conference on Autonomous Agents and Multiagent Systems (AAMAS-05). Utrech: ACM Press, 2005. p. 199-203.

GUYOT, P.; HONIDEN, S. Agent-based participatory simulations: Merging multi-agent systems and role-playing games. Journal of Artificial Societies and Social Simulation, v. 9, n. 4, 2006. ISSN 1460-7425. Http://jasss.soc.surrey.ac.uk/9/4/8.html.

HASSEGAWA, L. N. O Papel das Interfaces no Sucesso de Projetos Utilizando Equipes Virtuais. Dissertação (Mestrado) — Faculdade de Economia, Administração e Contabilidade (FEA) - Departamento de Administração, Universidade de São Paulo, 2002.

HOGLE, J. G. Considering Games as Cognitive Tools: In Search of Effective Edutainment. Georgia, USA, 1996.

HOOK, K. Designing and evaluating intelligent user interfaces. In: ACM. International Conference on Intelligent User Interfaces. San Francisco California - USA: ACM Press, 1998. p. 5-6.

HOOK, K.; SVENSSON, M. Footsteps in the snow: personal and social navigation in information space - Chapter: Evaluating Adaptive Navigation Support. Berlin: Springer, 1999. 
HUBER, G. P. Issues in the design of group decision support systems. Management Information Systems Quarterly, v. 8, n. 1, p. 195-204, 1984.

HUBNER, J. F. Um Modelo de Reorganização de Sistemas Multiagentes. Tese (Doutorado) - Escola Politecnica da Universidade de São Paulo, 2003.

HUBNER, J. F.; SICHMAN, J. S. SACI: Uma ferramenta para implementação e monitoração da comunicação entre agentes. In: MONARD, M.; SICHMAN, J. S. (Ed.). IBERAMIA/SBIA 2000, Open Discussion Track. Atibaia - São Paulo Brasil: Springer Verlag, 2000. p. 47-56.

JAPIASSU, H.; MARCONDES, D. Dicionário Básico de Filosofia. Rio de Janeiro: Jorge Zahar Editora, 1996.

JUnQUeIRA, R. G. P.; MATTOS, L. M. Projeto de Educação Ambiental Desafio das Águas. 2004. Http://www.ecoar.org.br/.

KERSTEN, G.; NORONHA, S. Negotiation via the world wide web: a cross-cultural study of decision making. Group Decision and Negotiation, v. 8, n. 1, p. 251-279, 1999.

KLIMICK, C. Construção de Personagem \& Aquisição de Linguagem: O Desafio do RPG no INES. Dissertação (Dissertação de Mestrado) - Programa de Pós-graduação do Departamento de Artes e Design - PUC, Rio de Janeiro, 2003.

KLUEGL, F.; OECHLEIN, C.; PUPPE, F. SeSAm. The Multi-Agent Simulation Environment. 2006. <http://www.simsesam.de>.

KROVI, R.; GRAESSER, A. C.; PRACHT, W. E. Agent behaviors in virtual negotiation environments. IEEE Transaction on Systems Man. and Cybernetics - Part C: Applications and Reviews, v. 29, n. 1, p. 15-25, February 1999.

LABROU, Y.; FININ, T. A proposal for a new KQML Specification. UMBC Baltimore, 1997.

LAIRD, J. The SOAR 8 Tutorial. 2003.

Http://sitemaker.umich.edu/soar/documentation. University of Michigan.

LAIRD, J.; NEWELL, A.; ROSENBLOOM, P. SOAR - an architecture for general intelligence. Artificial Intelligence, v. 1, n. 33, p. 1-64, 1987.

LAIRD, J. E.; CONGDON, C. B. The SOAR User's Manual - Version 8.5. University of Michigan, 2004.

LAIRD, J. E.; LENT, M. van. Human-level ai's killer application: Interactive computer games. AI Magazine, p. 15-25, 2001.

LEDERMAN, L. C. Debriefing : toward a systematic assessment of theory and practice. Simulation \& Gaming, v. 23, n. 2, p. 145-160, 1992.

LUCK, M.; MCBURNEY, P.; PREIST, C. Agent Technology: Enabling Next Generation Computing - A Roadmap for Agent Based Computing. 2003. Http://eprints.ecs.soton.ac.uk/7309/01/al2roadmap.pdf. 
MAES, P. The agent network architecture. Sigart Bulletin, v. 4, n. 2, p. 115-120, 1991.

MCKERSIE, R. B.; FONSTAD, N. O. Teaching negotiation theory and skills over the internet. Negotiation Journal, v. 13, n. 4, p. 363-368, October 1997.

MINAR, N. et al. The Swarm simulation system: a toolkit for building multi-agent simulations. 1996. Working Paper 96-06-042, Santa Fe Institute, Santa Fe. Http://www.swarm.org/archive/overview.ps.

MOREIRA, A. F.; BORDINI, R. H. An operational semantics for a BDI agent-oriented programming language. In: MEYER, J. C.; WOOLDRIDGE, M. J. (Ed.). Proceedings of the Workshop on Logics for Agent-Based Systems (LABS-02), held in conjunction with the Eighth International Conference on Principles of Knowledge Representation and Reasoning (KR2002). Toulouse, France: KR, Inc., 2002. p. $45-59$.

MOREIRA, A. F.; VIEIRA, R.; BORDINI, R. H. Extending the operational semantics of a BDI agent-oriented programming language for introducing speech-act based communication. In: Workshop on Declarative Agent Languages and Technologies (DALT-03), held with AAMAS-03. Melbourne, Australia: Springer Verlag, 2003.

MUCHINSKY, P. Psicologia Organizacional. São Paulo/SP: Thomson, 2004.

NANDALAL, K. D. W.; SIMONOVIC, S. P. Resolving conflicts in water sharing: a systemic approach. Water resources research, v. 39, n. 12, p. 1-10, 2003 .

NAREYEK, A. Constraint-Based Agents - An Architecture for Constraint-Based Modeling and Local-Search-Based Reasoning for Planning and Scheduling in Open and Dynamic Worlds. Berlin: Springer, 2001. LNAI 2062.

NEWELL, A.; SIMON, H. Human Problem Solving. Englewood Cliffs, NJ: Prentice-Hall, 1972.

NIELSEN, J. Usability Engineering. New Jersey: Academic Press, 1993.

NORLING, E.; SONENBERG, L.; RONNQUIST, R. Enhancing multi-agent based simulation with human decision-making strategies. In: MABS - The Second Workshop on Multi Agent Based Simulation. Bologna - Italy: Springer Verlag, 2000.

ORTONY, A.; ClORE, G. L.; COLlinS, A. The Cognitive Structure of Emotions. Cambridge, UK: Cambridge University Press, 1988.

PEPPET, S. R. Teaching negotiation using web-based straming video. Negotiation Journal, v. 18, n. 3, p. 271-283, July 2002.

PETERS, V.; VISSERS, G.; MEER, F.-B. v. d. Debriefing depends on purpose. In: GEURTS, J.; JOLDERSMA, F. (Ed.). Gaming/Simulation for Policy Development and Organizational Change - Proceedings of the 28Th Annual International Conference International Simulation and Gaming Association (ISAGA). Tilburg: Tilburg University Press, 1998. p. 399-404. 
PYNADATH, D. V.; TAMBE, M. An automated teamwork infrastructure for heterogeneous software agents and humans. Journal of Autonomous Agents and Multi-Agent Systems, v. 7, n. 1, p. 7-71, July 2003.

RAIFFA, H. The art $\&$ science of negotiation - How to resolve conflicts and get the best out of bargaining. MA: Harvard University Press, 1982.

RAMAGE, M. The Learning Way: Evaluating Co-operative Systems. Tese (Doctor of Philosophy) — Department of Computing - Lancaster University, April 1999.

RAO, A. S. AgentSpeak (L): BDI agents speak out in a logical computable language. In: VELDE, W. V. de; PERRAM, J. (Ed.). MAAMAW'96. London: Lecture Notes in Articial Inelligence - Springer-Verlag, 1996. p. 42-55.

RAO, A. S.; GEORGEFF, M. P. BDI agents: From theory to practice. Melbourne, Australia, 1995.

REBOnatTo, M. T. Um Estudo sobre Simulação Paralela. Dissertação (Mestrado) - Instituto de Informática, UFRGS, Porto Alegre, 1999. Mestrado em Ciência da Computação.

ROMMEL, M. Simple Object Access Protocol - Entendendo o Simple Object Access Protocol (SOAP). 2006.

Http://www.msdnbrasil.com.br/secure/sharepedia/arquivos/SOAP.pdf.

ROSS S., R. M.; ROGERS, Y. PETRA: Participatory Evaluation Through Redesign and Analysis. Interacting with Computers, v. 4, n. 7, p. 335-360, 1995.

RYDER, J.; ZACHARY, W. Experimental validation of the attention switching component of the COGNET framework. In: HUMAN FACTORS AND ERGONOMICS SOCIETY. Human Factors Society 35th Annual Meeting. Santa Monica, CA, 1991. p. 72-76.

RYDER, J. M. et al. Cognitive engineering of a new telephone operator workstation using COGNET. Internacional Journal of Industrial Ergonomics, v. 22, n. 6, p. 417-429, 1998.

SANDHOLM, T. Negotiation among Self-Interested Computationally Limited Agents. Tese (Doutorado) - University of Massachusetts at Amherst, Department of Computer Science, 1996.

SMITH, R.; DAVIS, R. Distributed problem solving: the contract-net approach. In: Proceedings of the Second National Conference of the Canadian Society for Computational Studies of Intelligence. Toronto, Canada: Canadian Society for Computational Studies of Intelligence, 1978. p. 278-287.

STERN, E. The evaluation of policy and the politics of evaluation. Tavistock Institute Annual Review, p. 28-30, 1991.

STRACK, J. GPSS: modelagem e simulação de sistemas. Rio de Janeiro: LTC, 1984. $174 \mathrm{p}$.

THOYER, S. et al. A bargaining model to simulate negotiations between water users. Journal of Artificial Societies and Social Simulation, v. 4, n. 2, 2001. Http://www.soc.surrey.ac.uk/JASSS/4/2/6.html. 
TWIDALE, M.; RANDALL, D.; BENTLEY, R. Situated evaluation for cooperative systems. In: $C S C W$ 94. Chapel Hill, North Carolina, USA: CSCW Press, 1994. p. 441-452.

VIVACQUA, A.; LIEBERMAN, H. Agents to assist in finding help. In: TURNER, T. et al. (Ed.). Proceedings of the ACM CHI 2000 Human Factors in Computing Systems Conference. The Hague, The Netherlands, 2000. p. 65-72.

W3C. W3C - World Wide Web Consortium - SOAP - Simple Object Access Protocol - Specifications. 2005. Http://www.w3.org/TR/soap/.

WEBOPEDIA. What is decision support system? A word definition from the Webopedia Computer Dictionary. December 2006. Http://www.webopedia.com/TERM/D/decision_support_system.html.

WINOGRAD, T.; FLORES, F. Understanding Computers and Cognition. Reading, MA: Addison-Wesley, 1986.

ZACHARY, W.; RYDER, J. M.; HICINBOTHOM, J. Cognitive task analysis and modeling of decision making in complex environments. In: CANNONBOWERS, J.; SALAS, E. (Ed.). Decision Making Under Stress: Implications for Training and Simulation. Washington, DC: American Psychological Association, 1998.

ZHANG, S.; FJERMESTAD, J.; TREMAINE, M. Leadership styles in virtual team context: Limitations, solutions and propositions. In: Proceedings of the 38th Hawaii International Conference on System Sciences. Island of Hawaii Big Island: IEEE, 2005. 